UNIVERSIDADE DE SÃO PAULO

FACULDADE DE FILOSOFIA, LETRAS E CIÊNCIAS HUMANAS DEPARTAMENTO DE LINGÜÍSTICA

PROGRAMA DE PÓS-GRADUAÇÃO EM SEMIÓTICA E LINGÜÍSTICA GERAL

\title{
UMA ANÁLISE QUALITATIVA DE MARCADORES \\ CULTURAIS EM DOIS CORPORA PARALELOS DE TRADUÇÕES JURÍDICAS DE DIREITO PRIVADO DE PORTUGUÊS PARA INGLÊS E DE INGLÊS PARA PORTUGUÊS
}

\begin{abstract}
Naomi James Sutcliffe de Moraes
Tese apresentada ao Programa de Pós-Graduação em Semiótica e Lingüística Geral, do Departamento de Lingüística da Faculdade de Filosofia, Letras e Ciências Humanas da Universidade de São Paulo, para obtenção do título de Doutora em Lingüística
\end{abstract}

Orientador: Prof. Dr. Francis Henrik Aubert

São Paulo 


\section{UMA ANÁLISE QUALITATIVA DE MARCADORES CULTURAIS EM DOIS CORPORA PARALELOS DE TRADUÇÕES JURÍDICAS DE DIREITO PRIVADO DE PORTUGUÊS PARA INGLÊS E DE INGLÊS PARA PORTUGUÊS}


DEDICATÓRIA

To my husband Vítor, with deepest gratitude and love. 


\section{AGRADECIMENTOS}

Agradeço a orientação e revisão de meu orientador, Prof. Dr. Francis H. Aubert.

Agradeço as contribuições de meus colegas, sem as quais não teria tido um corpus com o qual trabalhar.

Agradeço a boa vontade do colega Luís Henrique Kubota pelo

empréstimo do dicionário jurídico de Maria Helena Diniz.

Agradeço a boa vontade da minha orientadora anterior, Profa. Dra. Salete de Almeida Cara.

e

Agradeço o apoio moral e paciência de meu marido, Prof. Dr. Vítor H. Nascimento. 


\title{
RESUMO
}

Esta tese apresenta uma análise qualitativa da tradução de marcadores culturais referenciais (extra-lingüísticos) e estilísticos (convenções lingüísticas) em dois corpora paralelos de documentos da área de direito privado, um com originais em português brasileiro e traduções em inglês e o outro com originais em inglês e traduções em português brasileiro. Os corpora não contêm traduções de aprendizes. Dividiu-se os marcadores em categorias temáticas para identificar tendências de abordagem. As análises incluíram classificação das soluções tradutórias através das modalidades de Aubert (2005), com modificações, e graus de aproximação do receptor ao texto original. Dois corpora comparáveis em inglês e português também foram coletados e utilizados para servir como uma referência para questões estilísticas.

\begin{abstract}
This dissertation is a qualitative analysis of the translation of referential (extra-linguistic) and stylistic cultural markers in two parallel corpora containing documents from the area of private law, one with originals in Brazilian Portuguese and translations in English and the other with originals in English and translations in Brazilian Portuguese. The corpora contain translations performed by professionals, not students of translation. The cultural markers were categorized thematically to allow identification of translation strategy trends. The analyses included classification of translation solutions using the modalities of Aubert (2005), with modifications, and degrees of approximation between the receptor and the original text. Two comparable corpora in English and Brazilian Portuguese were also compiled and used as a reference for stylistic questions.
\end{abstract}

PALAVRAS CHAVES: tradução jurídica, corpora paralelos, modalidades de tradução, inglês, grau de aproximação

KEY WORDS: legal translation, paralel corpora, translation shifts, Portuguese, degree of approximation 


\section{Índice}

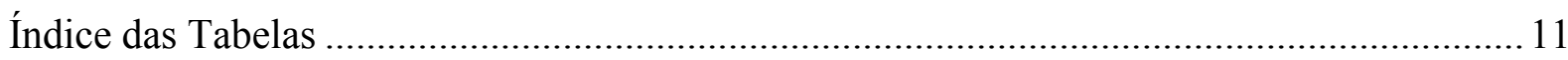

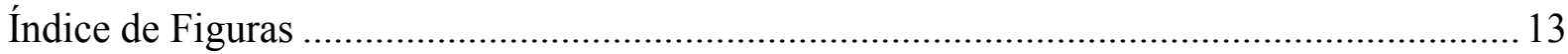

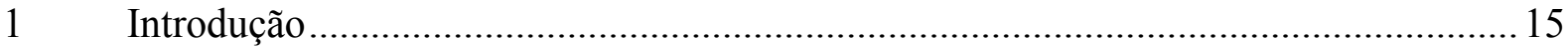

1.1 Definição do problema e sua relevância..................................................................... 15

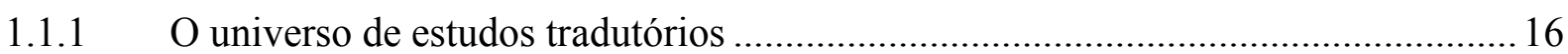

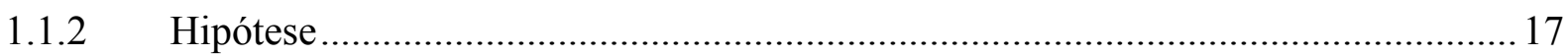

1.2 Metodologia e abordagem deste estudo ............................................................ 18

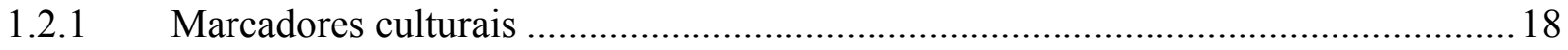

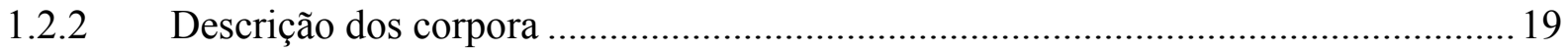

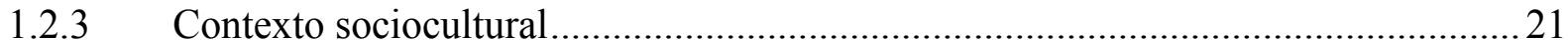

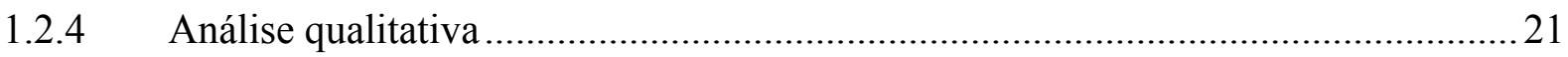

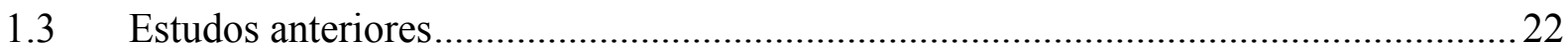

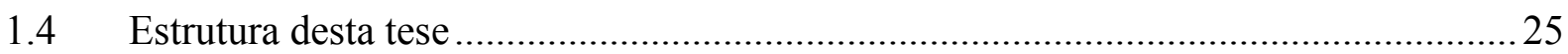

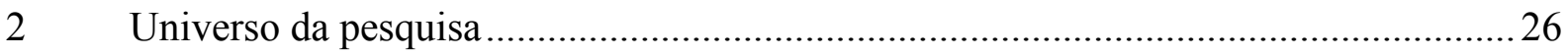

2.1 Histórico do universo jurídico no Brasil, nos EUA e na Grã-Bretanha ......................26

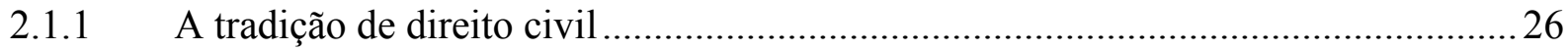

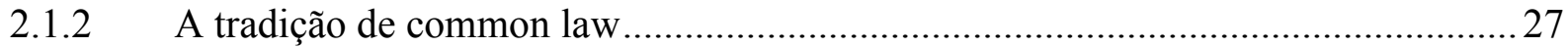

2.2 Aspectos discursivos e lingüísticos da procuração..................................................29

2.2.1 Aspectos discursivos e lingüísticos da procuração norte-americana e britânica......29

2.2.2 Aspectos discursivos e lingüísticos da procuração brasileira ................................... 30

2.2.3 Semelhanças e diferenças nos aspectos discursivos e lingüísticos de procurações.. 32

2.3 Tipos de sociedades e sua organização no Brasil, nos EUA e na Grã-Bretanha.......... 33

2.3.1 Pessoas Jurídicas no Brasil.................................................................................... 33

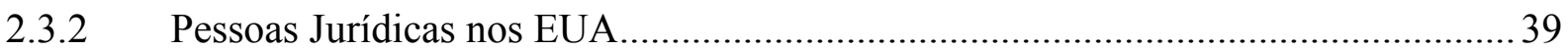

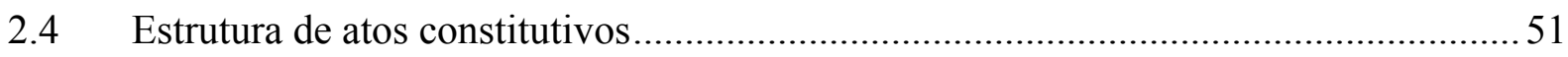

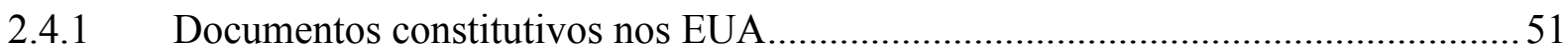

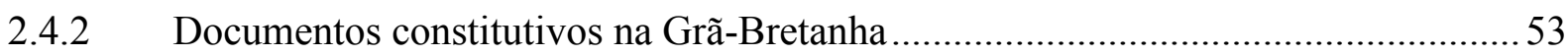

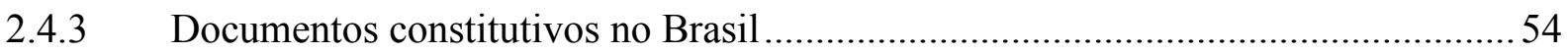

2.4.4 Correspondências e possíveis equivalências operacionais e funcionais ..................55

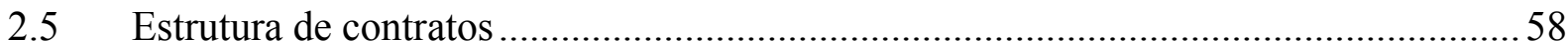


2.5.1 A estrutura de contratos nos EUA e na Grã-Bretanha...........................................58

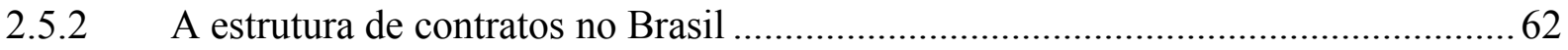

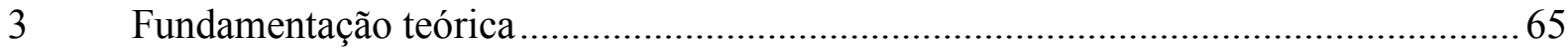

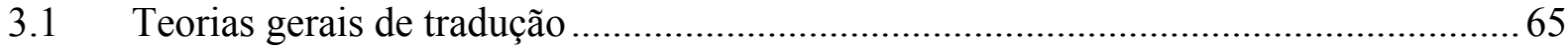

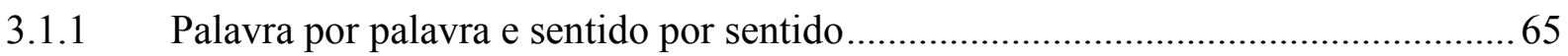

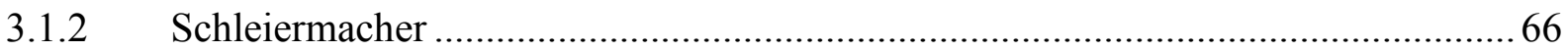

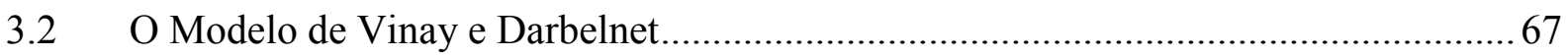

3.3 Modificações do modelo de Vinay e Darbelnet ......................................................... 70

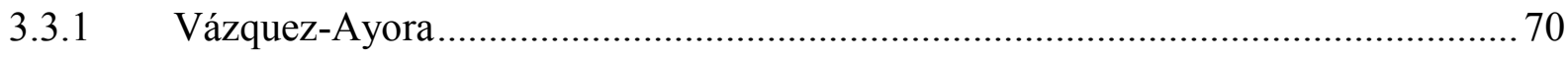

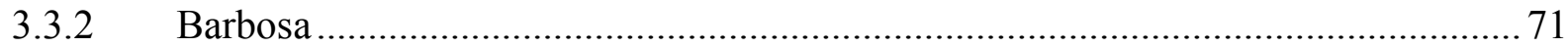

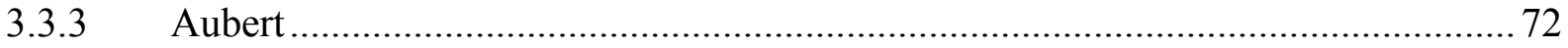

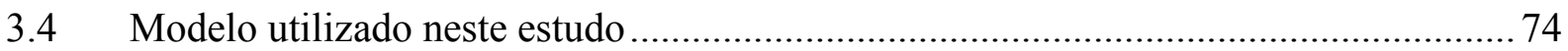

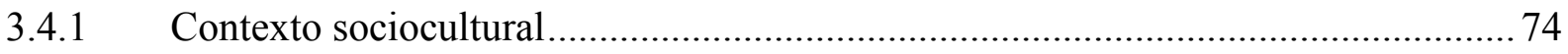

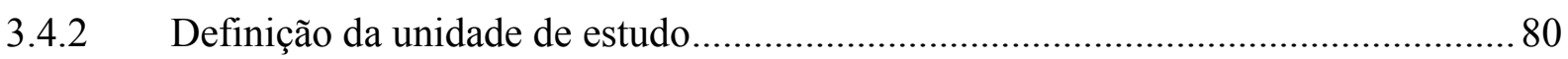

3.4.3 Definição das modalidades de tradução ................................................................ 81

3.4.4 Resumo das modalidades de tradução ..................................................................... 92

3.4.5 Classificação das categorias segundo o grau de aproximação do receptor ao texto original 94

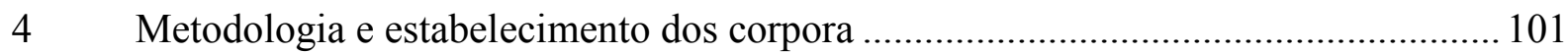

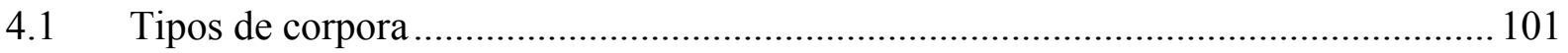

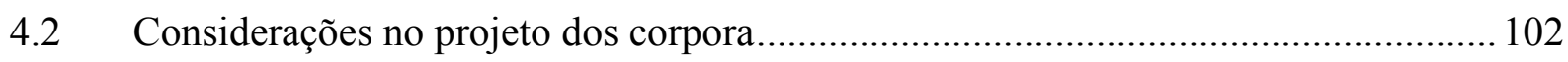

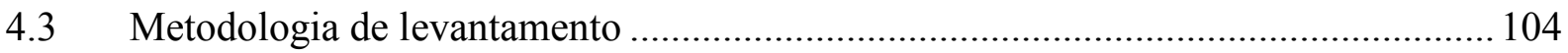

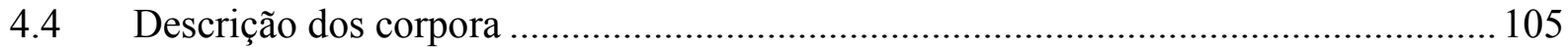

4.4.1 Ing-br — Traduções do inglês para o português .................................................... 106

4.4.2 Br-ing — Traduções do português para o inglês..................................................... 108

4.4.3 Descrições dos arquivos nos corpora paralelos, por tipo ...................................... 112

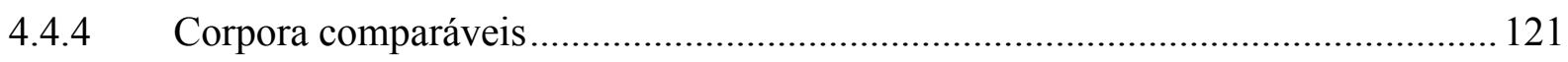

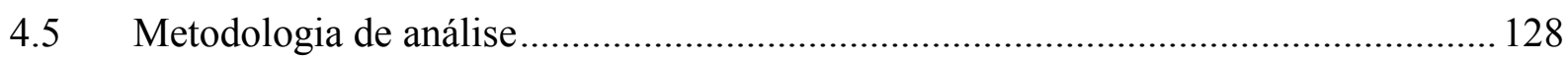

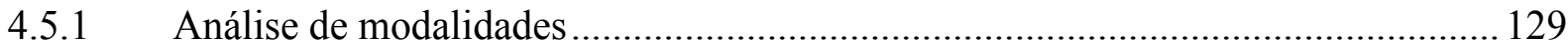

4.5.2 Análise de graus de aproximação ..................................................................... 131

4.5.3 Análise de variáveis secundárias ....................................................................... 132 


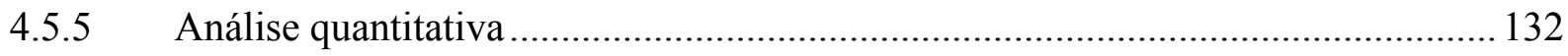

5 Análise qualitativa e quantitativa da tradução de marcadores referenciais ................ 134

5.1 Tipos de sociedades e outras pessoas jurídicas .................................................... 134

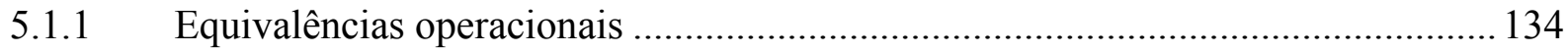

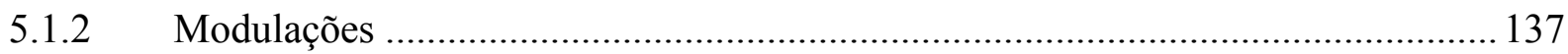

5.1.3 Traduções literais e equivalências funcionais .................................................... 139

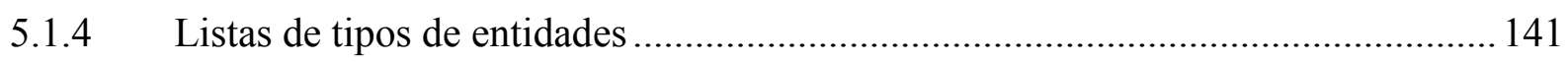

5.1.5 Resumo de freqüência de ocorrência e conclusões .............................................. 146

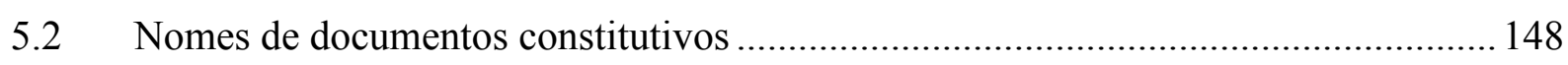

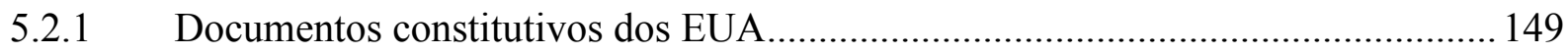

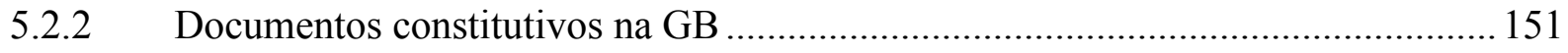

5.2.3 Documentos constitutivos no Brasil................................................................. 154

5.2.4 Resumo de freqüência de ocorrência e conclusões ............................................ 158

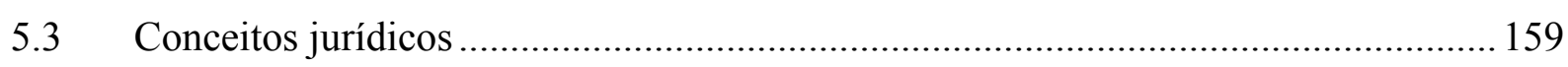

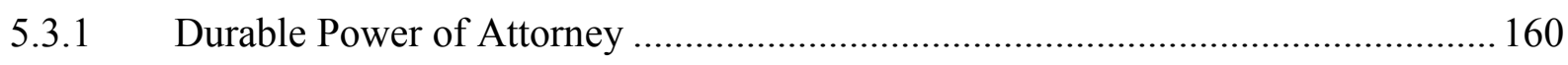

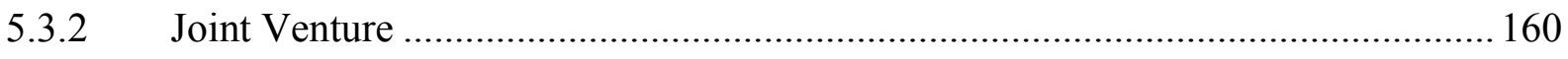

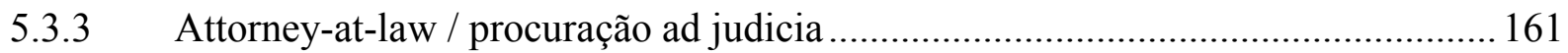

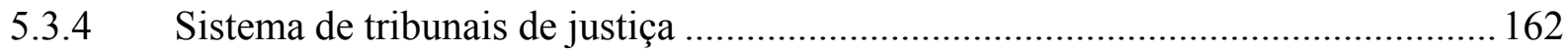

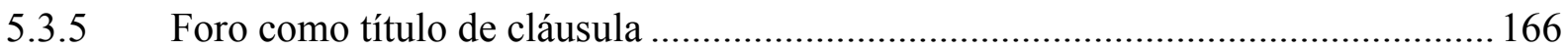

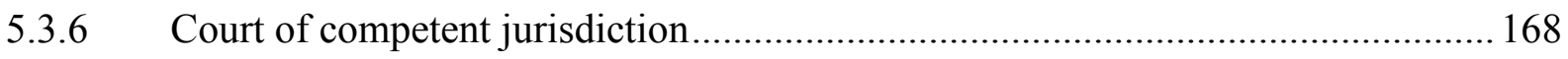

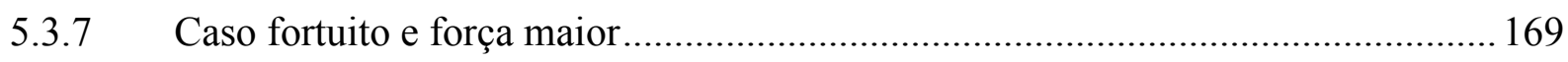

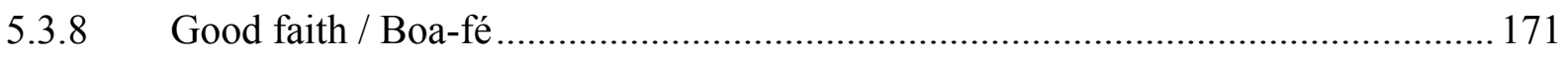

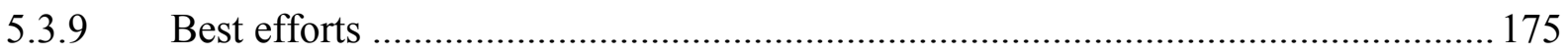

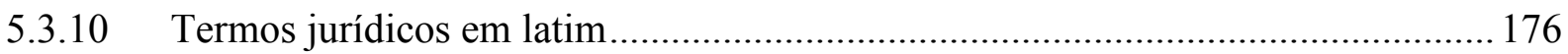

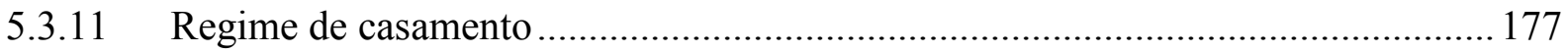

5.3.12 Resumo de freqüência de ocorrência e conclusões ............................................. 178

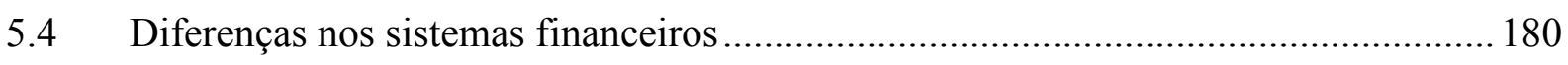

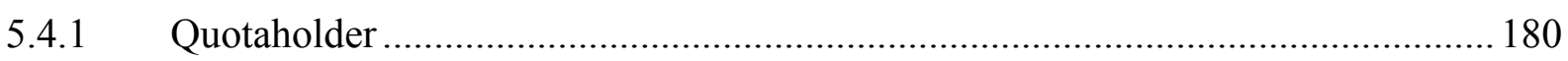

5.4.2 Retirar talões e pagar contas através de boleto bancário ...................................... 182

5.4.3 Índices de correção monetária ............................................................................... 183

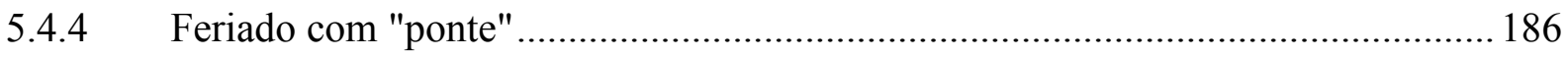




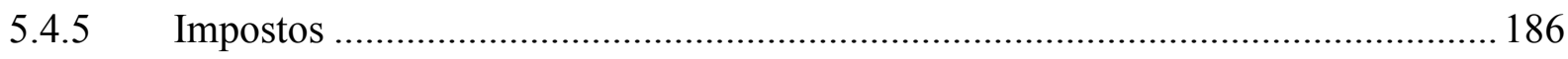

5.4.6 Resumo de freqüência de ocorrência e conclusões .............................................. 187

5.5 Qualificações de pessoas físicas e jurídicas .......................................................... 189

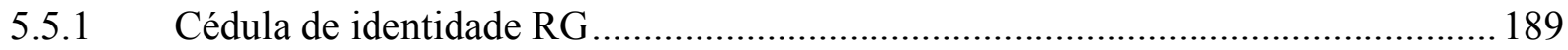

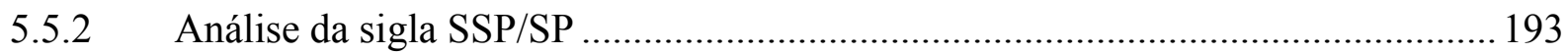

5.5.3 Outras qualificações de pessoas físicas - OAB e RNE .......................................... 194

5.5.4 Qualificação de pessoas jurídicas - CNPJ, JUCESP .............................................. 195

5.5.5 Resumo de freqüência de ocorrência e conclusões .............................................. 198

6 Análise qualitativa e quantitativa da tradução de marcadores estilísticos.................. 201

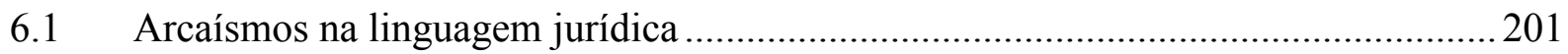

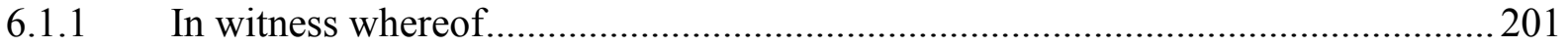

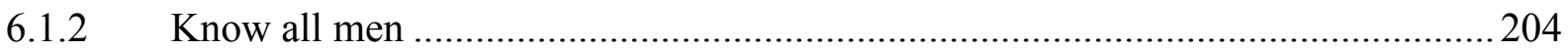

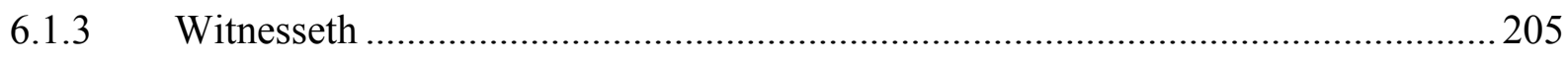

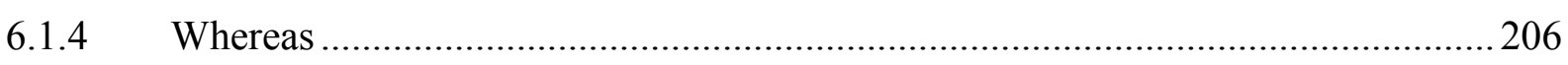

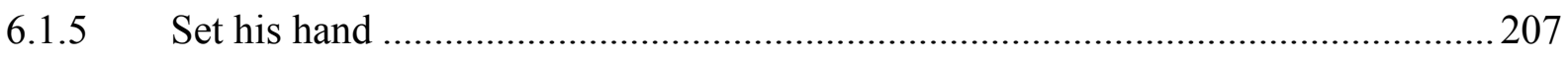

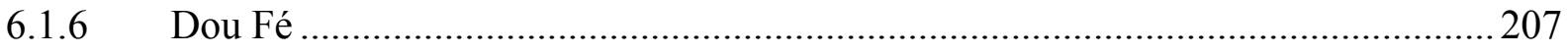

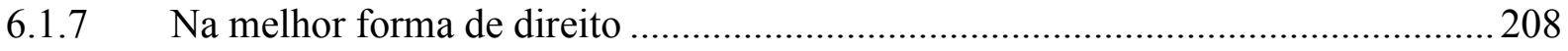

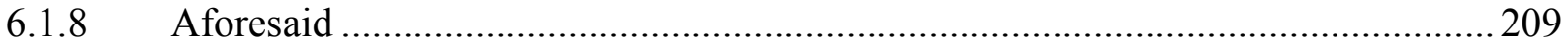

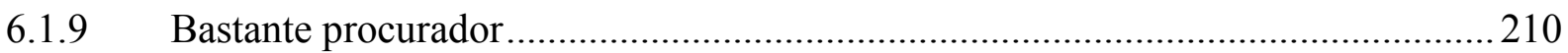

6.1.10 Resumo das freqüências de ocorrência e conclusões ..........................................211

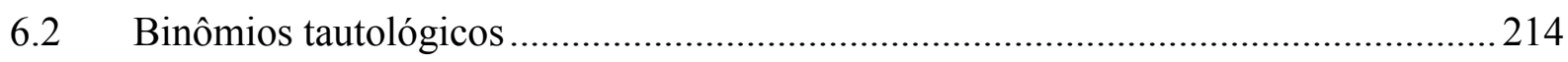

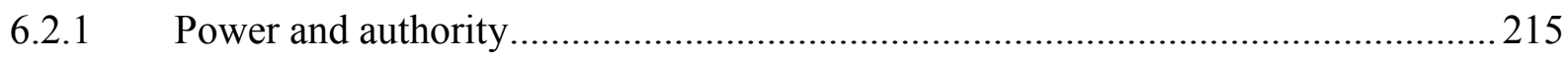

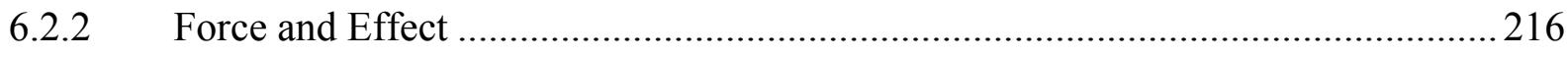

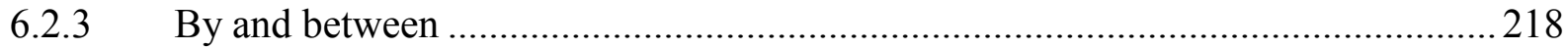

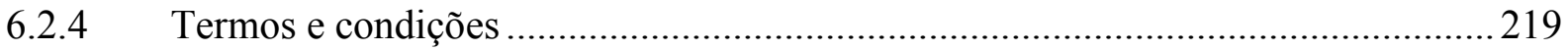

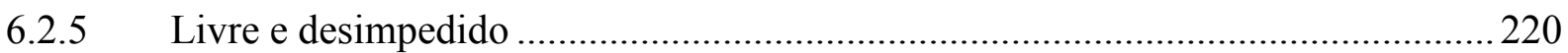

6.2.6 Resumo de freqüências de ocorrência e conclusões...........................................221

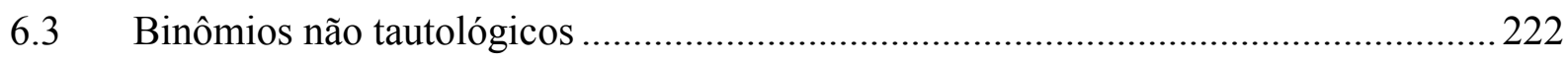

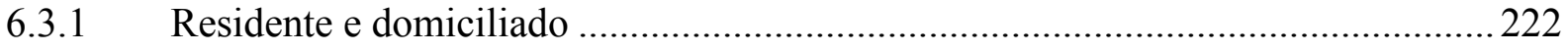

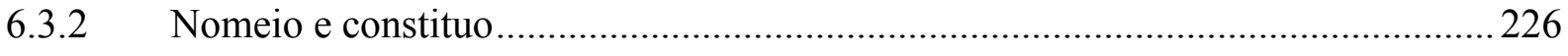

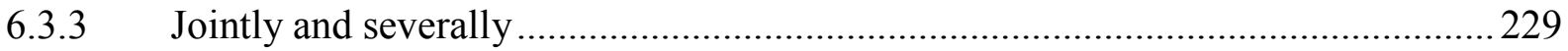




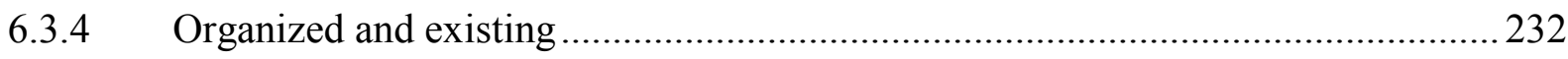

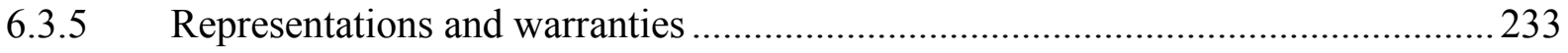

6.3.6 Resumo das freqüências de ocorrência e conclusões ..........................................2235

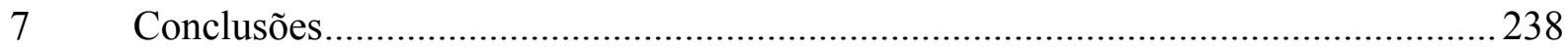

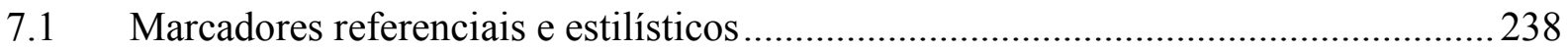

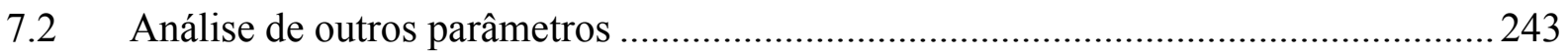

7.2.1 Traduções para o inglês e para o português ......................................................... 243

7.2.2 Traduções juramentadas e não juramentadas ..................................................... 247

7.2.3 Traduções para a língua de domínio mais ativo e não............................................249

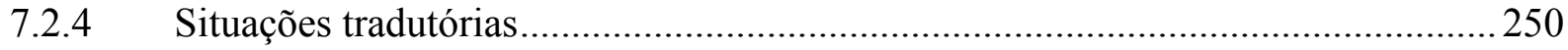

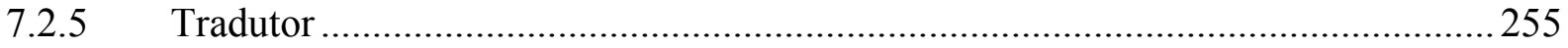

7.3 Análises de graus de aproximação e modalidades específicos.................................258

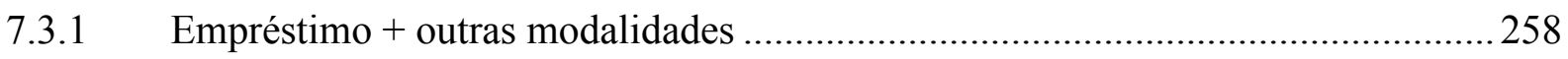

7.3.2 Tradução literal vs. grau de aproximação............................................................ 259

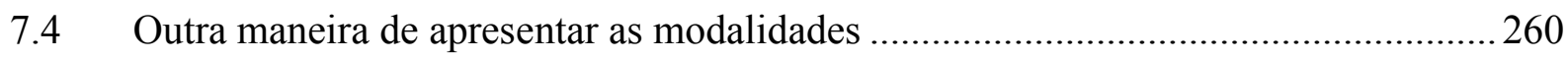

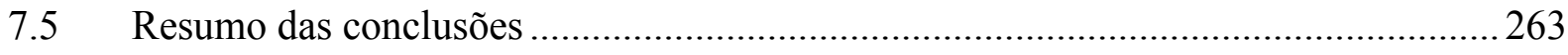

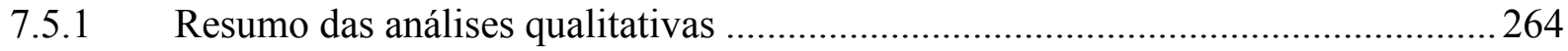

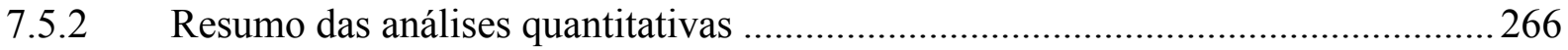

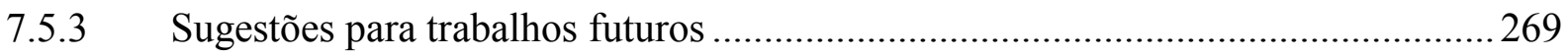

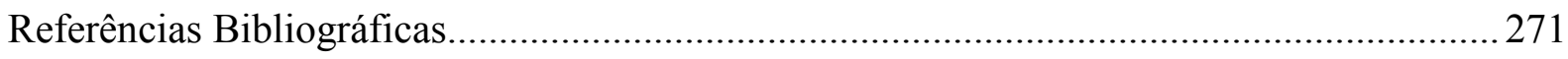

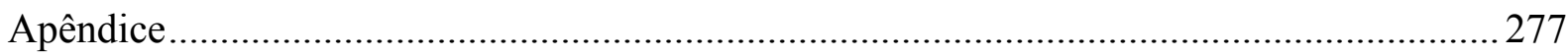




\section{Índice das Tabelas}

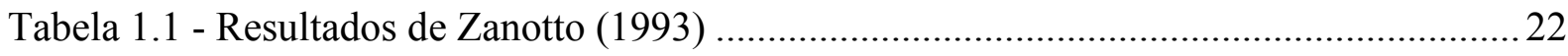

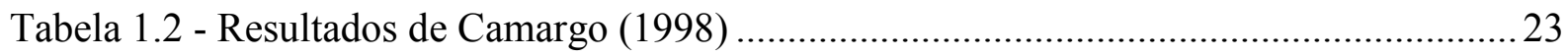

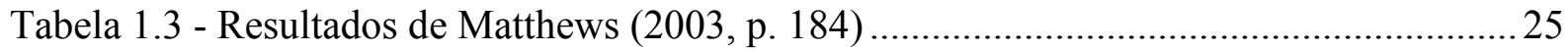

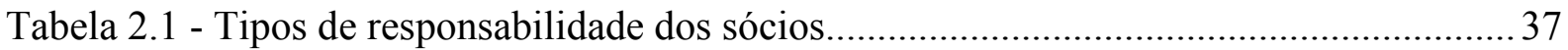

Tabela 2.2 - Possíveis equivalências operacionais .............................................................. 51

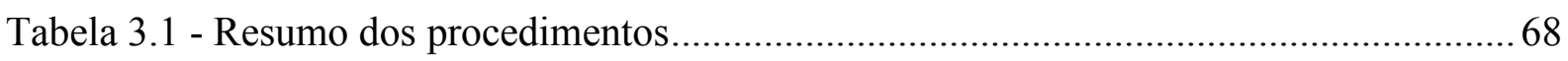

Tabela 3.2 - Categorização dos procedimentos por Barbosa (2004) ....................................... 72

Tabela 3.3 - Resumo das modalidades de Aubert (2005a) ...................................................... 74

Tabela 3.4 - Resumo das modalidades deste estudo.............................................................. 94

Tabela 4.1 - Descrição do corpus paralelo ing-br................................................................. 108

Tabela 4.2 - Descrição do corpus paralele br-ing ................................................................ 111

Tabela 4.3 - Número de palavras nos corpora ing-br e br-ing............................................ 111

Tabela 4.4 - Número de palavras e documentos por tradutor................................................ 112

Tabela 4.5 - Descrição dos arquivos no corpus comparável br-orig ..................................... 126

Tabela 4.6 - Descrição dos arquivos no corpus comparável ing-orig .................................... 127

Tabela 4.7 - Códigos utilizados para as modalidades.......................................................... 131

Tabela 5.1 - Freqüência de ocorrência de modalidade por grau de aproximação — tipos de

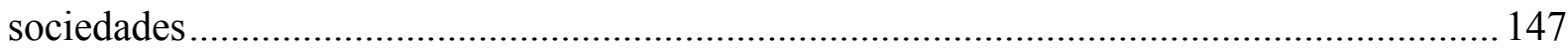

Tabela 5.2 - Freqüência de ocorrência de modalidade por grau de aproximação -

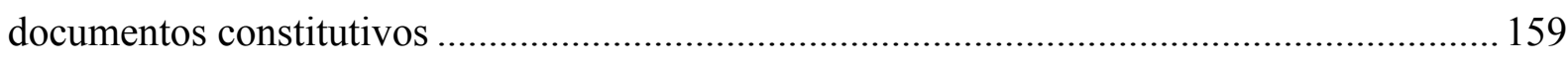

Tabela 5.3 - Freqüência de ocorrência de modalidade por grau de aproximação — conceitos

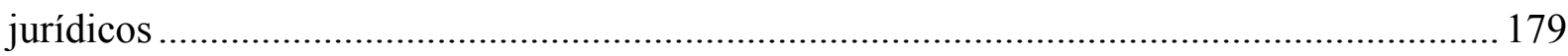

Tabela 5.4 - Freqüência de ocorrência de modalidade por grau de aproximação — conceitos

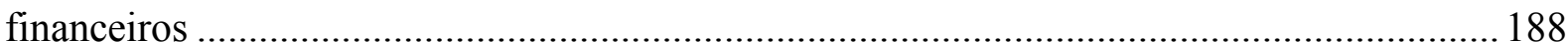

Tabela 5.5 - Freqüência de ocorrência de modalidade por grau de aproximação -

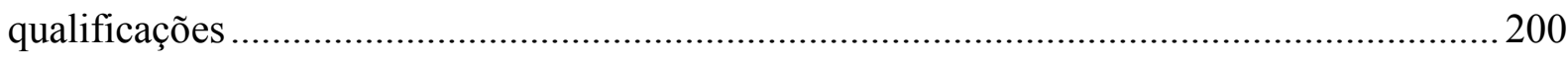

Tabela 6.1 - Freqüência de ocorrência de modalidade por grau de aproximação — arcaísmos

Tabela 6.2 - Freqüência de ocorrência por grau de aproximação — arcaísmos — por corpus paralelo 
Tabela 6.3 - Freqüência de ocorrência para graus de aproximação 2 e 5 - arcaísmos — por corpus paralelo e por traduções juramentadas ou não

Tabela 6.4 - Freqüência de ocorrência de modalidade por grau de aproximação — binômios tautológicos 222

Tabela 6.5 - Freqüência de ocorrência de modalidade por grau de aproximação — binômios não tautológicos 236

Tabela 7.1 - Resumo de freqüência de ocorrência por grau por tipo de marcador. 238

Tabela 7.2 - Resumo de freqüência de ocorrência por grau por tipo de marcador (percentagens)

Tabela 7.3 - Resumo de freqüência de ocorrência por modalidade por tipo de marcador ......241 Tabela 7.4 - Resumo de freqüência de ocorrência por modalidade por tipo de marcador (percentagens)

Tabela 7.5 - Ocorrências e \% de exemplos por grau de documentos traduzidos para português (corpus ing-br) e para inglês (corpus br-ing) - marcadores referenciais

Tabela 7.6 - Ocorrências e \% de exemplos por grau de documentos traduzidos para português (corpus ing-br) e para inglês (corpus br-ing) - marcadores estilísticos....

Tabela 7.7 - Percentagens de exemplos por modalidade traduzidos para português (corpus ingbr) e para inglês (corpus br-ing) — resumidas.....

Tabela 7.8 - Ocorrências e \% de exemplos por grau de documentos juramentados e não corpus ing-br.

Tabela 7.9 - Ocorrências e \% de exemplos por grau de documentos juramentados e não corpus br-ing.

Tabela 7.10 - Ocorrrências e \% de exemplos por grau de documentos traduzidos para a LDA do tradutor e não - corpus br-ing . 250

Tabela 7.11 - Percentagem de ocorrências por grau por situação tradutória 252

Tabela 7.12 - Percentagem de ocorrência por grau por tradutor — corpus ing-br. 255

Tabela 7.13 - \% de ocorrência por grau por tradutor - corpus br-ing ..... 257

Tabela 7.14 - Modalidades com empréstimo nos dois corpora paralelos 259

Tabela 7.15 - Freqüência de Ocorrência de cada modalidade tomada separadamente . 261

Tabela 7.16 - Comparação com os dados de Matthews (2003)..... 262

Tabela 7.17 - Dados deste estudo segundo as categorias de Aubert (2005a).... 263 


\section{Índice de Figuras}

Figura 1.1 - Versão simplificada do esquema de Holmes .................................................... 16

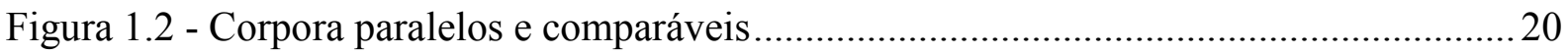

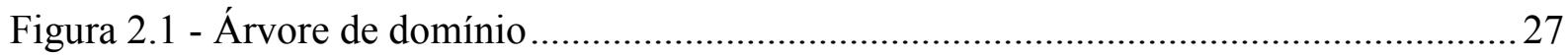

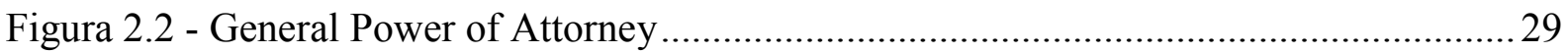

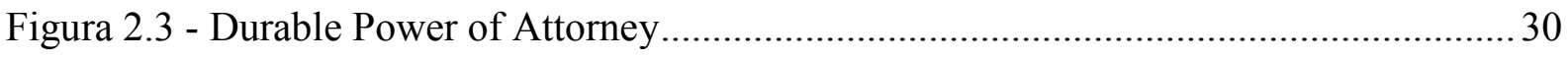

Figura 2.4 - Procuração para Compra de Bem Imóvel ............................................................. 31

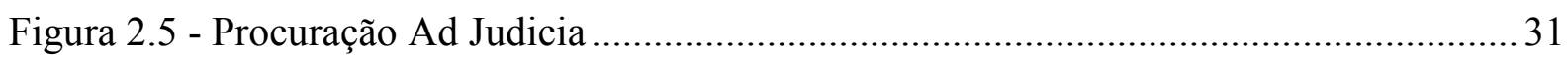

Figura 2.6 - Categorização de tipos de sociedades segundo a lei brasileira ............................. 36

Figura 2.7 - Categorização de tipos de sociedades segundo a lei norte-americana.................. 40

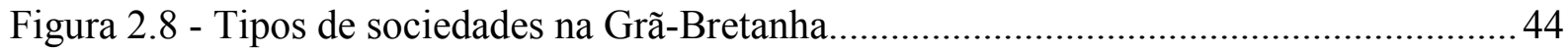

Figura 2.9 - Equivalências para o profissional autônomo ...................................................... 45

Figura 2.10 - Equivalências para a sociedade limitada ..................................................... 47

Figura 2.11 - Equivalências para a sociedade anônima........................................................... 48

Figura 2.12 - Equivalências para a Limited Partnership ..................................................... 49

Figura 2.13 - Equivalências no caso de responsabilidade ilimitada e solidária .......................50

Figura 2.14 - Documentos constitutivos nos EUA e na GB ....................................................54

Figura 2.15 - Documentos constitutivos da Limited Liability Company/Sociedade Limitada 55

Figura 2.16 - Documentos constitutivos da Corporation/Sociedade Anônima ......................... 56

Figura 2.17 - Documentos constitutivos da Company/Sociedade Anônima/Sociedade Limitada

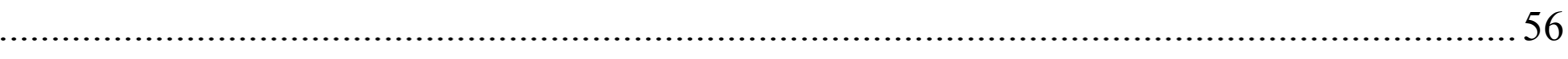

Figura 2.18 - Possíveis correspondências para estatuto e contrato social ...............................57

Figura 2.19 - Possíveis correspondências para documentos constitutivos em inglês............... 58

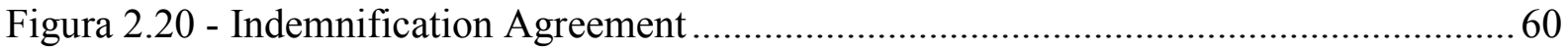

Figura 2.21 - Instrumento Particular de Comodato de Móvel................................................ 63

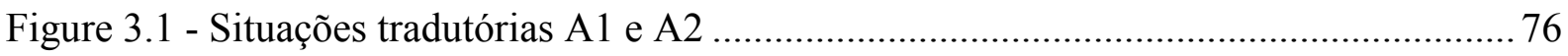

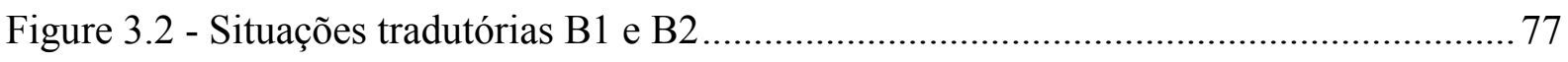

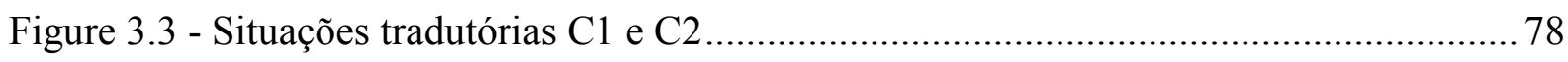

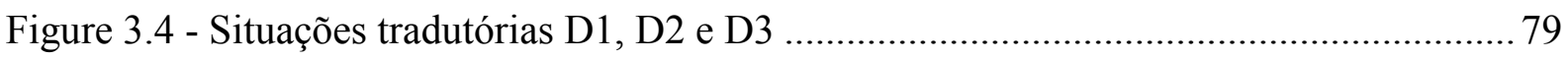

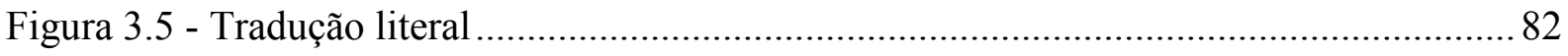

Figura 3.6 - Evolução das categorias modulação e equivalência ............................................. 85 
Figura 3.7 - Evolução das categorias explicitação, omissão, implicitação e acréscimo 90

Figura 3.8 - Evolução das modalidades empréstimo, decalque e transcrição .......................... 91

Figura 3.9 - Graus de aproximação do receptor ao escritor do texto original ......................... 95

Figura 3.10 - Exemplo de graus de aproximação — sociedade limitada ................................. 96

Figura 3.11 - Exemplo de graus de aproximação - RG No ................................................ 98

Figura 3.12 - Exemplo de graus de aproximação - Comarca................................................ 99

Figura 5.1 - Freqüência de ocorrência de cada grau de aproximação — tipos de sociedades 146 Figura 5.2 - Freqüência de ocorrência de cada grau de aproximação — documentos constitutivos. 158

Figura 5.3 - Freqüência de ocorrência de cada grau de aproximação — conceitos jurídicos 178 Figura 5.4 - Freqüência de ocorrência de cada grau de aproximação - conceitos financeiros

Figura 5.5 - Freqüência de ocorrência de cada grau de aproximação - qualificações ......... 199

Figura 6.1 - Freqüência de ocorrência de cada grau de aproximação — arcaísmos ...............212

Figura 6.2 - Freqüência de ocorrência de cada grau de aproximação — binômios tautológicos

Figura 6.3 - Freqüência de ocorrência de cada grau de aproximação — binômios não

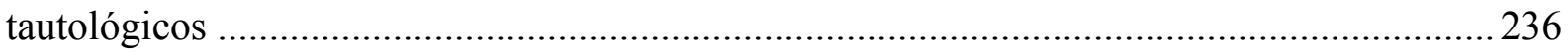

Figura 7.1 - Resumo de freqüência de ocorrência por grau por tipo de marcador .................239 Figura 7.2 - \% de Ocorrência por grau para os dois sentidos tradutórios, com ajuste -

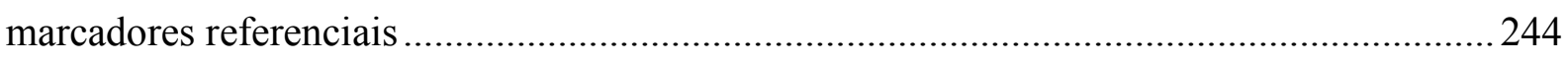

Figura 7.3 - Percentagem de ocorrências por grau para situações A1, B1, C1 e C2 ............. 253

Figura 7.4 - Percentagem de ocorrências por grau para situações A2, D1 e D2 _................... 254

Figura 7.5 - Percentagem de ocorrência por grau por tradutor - corpus ing-br - tradutores B, E,

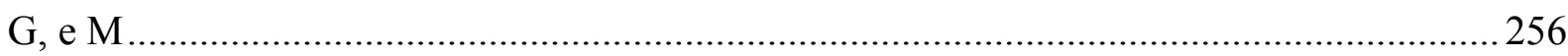

Figura 7.6 - \% de ocorrência por grau por tradutor - corpus br-ing - tradutores D, E, L e M 257 Figura 7.7 - Freqüência de ocorrência por grau para tradução literal ....................................260

Figura 7.8 - \% de ocorrência por grau por sentido ......................................................... 267 


\section{Introdução}

\subsection{Definição do problema e sua relevância}

A tradução jurídica é um caso especial, até extremo, de tradução de textos não literários, pois deve-se levar em conta não só os contextos culturais e sociais do país e idioma de origem ao se traduzir o documento, mas também as diferenças jurídicas entre os dois países, especialmente quando um segue o padrão do direito civil e o outro não. Seria como converter um texto veterinário de um idioma para um texto médico em outro, em que um bigode de gato não é exatamente o bigode de um homem. É necessário encontrar um equilíbrio entre a tradução do conteúdo-levando-se em conta o fato de que os conhecimentos do leitor do original são diferentes dos conhecimentos do leitor da tradução - e o uso de terminologia e fraseologia do idioma/universo jurídico da língua e país da tradução. Até que ponto a tradução precisa exibir sua alteridade?

Este estudo descritivo tenta responder a esta dúvida mediante uma investigação acerca das soluções encontradas na relação tradutória entre os universos lingüístico-discursivos (EUAGrã-Bretanha/Brasil). A despeito de os universos jurídicos dos EUA e do Brasil serem diversos - implicando pressupostos diferentes, recortes semânticos não-coincidentes, e mesmo lacunas conceituais entre um e outro universo - a tradução de textos jurídicos se faz cotidianamente. As diferenças, portanto, não são impeditivas da criação de relações de equivalência, sejam funcionais, descritivas, operacionais ou culturais, estáveis e previsíveis ou ad hoc e dependentes do contexto / condições de produção da tradução.

Neste estudo, coletei traduções jurídicas de colegas - todos tradutores profissionais com vários anos de experiência e sucesso no mercado. Em lugar de estudar todas as escolhas feitas, mesmo as triviais, considerei mais recompensador estudar a tradução das dificuldades tradutórias, nesse trabalho chamadas de marcadores culturais referenciais e estilísticos. 


\subsubsection{O universo de estudos tradutórios}

Em 1972, Holmes $(1972,2000)$ apresentou um trabalho no qual delineou o desenvolvimento dos estudos tradutórios. O esquema de Holmes, publicado mais tarde por Toury $(1995$, p. 10), é apresentado em forma abreviada na figura 1.1 .

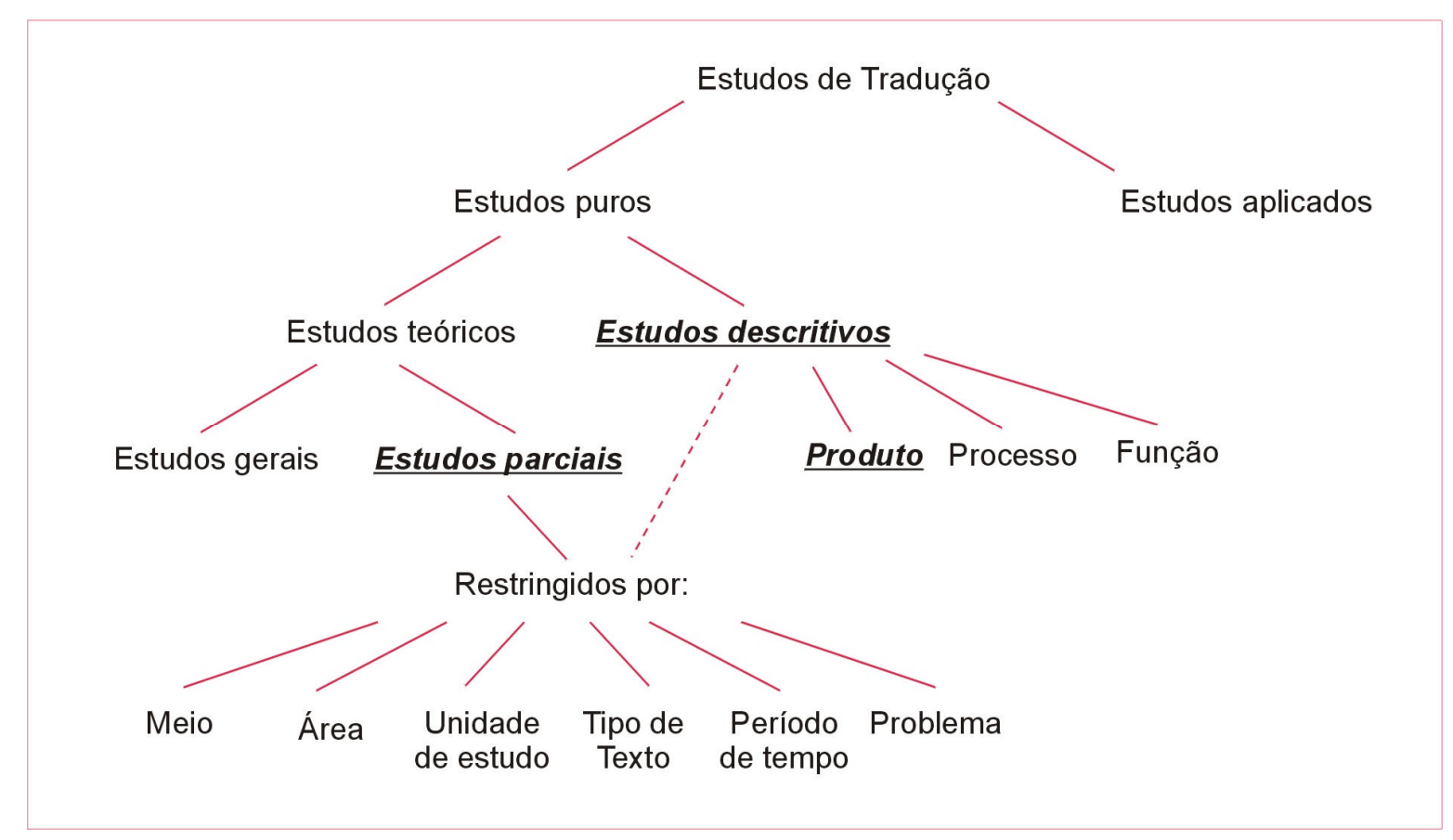

Figura 1.1 - Versão simplificada do esquema de Holmes

A primeira divisão é entre estudos puros e estudos aplicados (ensino e crítica). Os estudos puros consistem em estudos teóricos e estudos descritivos. Os estudos descritivos procuram descrever os fenômenos da tradução, enquanto os estudos teóricos buscam explicar e predizer estes fenômenos. Holmes dividiu os estudos teóricos em mais duas categorias: estudos gerais e estudos parciais. Os estudos teóricos gerais tentam criar teorias que se aplicam a qualquer tipo de tradução, enquanto os estudos teóricos parciais analisam uma categoria mais restrita de traduções.

Os estudos descritivos podem focar o produto, analisando traduções existentes, a função de traduções na cultura receptora ou o processo de tradução, ou seja, o raciocínio do tradutor ao 
traduzir. Os resultados dos estudos descritivos podem servir de base para estudos teóricos. As análises também podem se restringir a um meio, a um tipo de texto, a um par de idiomas ou até só um sentido tradutório, a um período específico, ou a um tipo específico de problema, como mostrado na figura 1.1.

O presente estudo é um estudo descritivo parcial que analisa traduções existentes de:

1) somente um tipo de texto, o documento jurídico civil (veja a seção 4.4 para uma descrição detalhada do corpus),

2) somente um par de idiomas (inglês/português) nos dois sentidos tradutórios,

3) somente três países (Brasil, Estados Unidos e Reino Unido),

4) somente um período específico (os últimos 10 anos), e

5) somente um tipo específico de problema, ou seja, a tradução de marcadores culturais.

6) somente um meio - a palavra escrita.

\subsubsection{Hipótese}

O presente trabalho parte da hipótese de que é possível identificar uma maneira preferida (ou consagrada) de traduzir o discurso jurídico de um idioma para outro (especificamente inglês para português e vice-versa) quando os universos jurídicos (especificamente os Estados Unidos/Reino Unido e o Brasil) são tão diversos e muitos conceitos jurídicos existem somente em um dos universos; e que esta norma oculta pode ser deduzida através da categorização de problemas tradutórios em um corpus paralelo bilíngüe de textos jurídicos e do estudo das soluções ali encontradas. Espera-se ver um padrão para marcadores de categorias diferentes, e dependente da distância entre os conceitos nas duas culturas.

A questão é multifacetada porque o texto de origem não é a única influência na tradução. Há o idioma de domínio mais ativo do tradutor, sua familiaridade com documentos semelhantes ou equivalentes na língua de chegada, o porquê da tradução (a situação tradutória), a filosofia do tradutor (quanto a literalidade), etc. 


\subsection{Metodologia e abordagem deste estudo}

A abordagem deste estudo é selecionar trechos de texto (chamados de unidades de estudo) e analisar as soluções através de dois esquemas de classificação. O primeiro é uma análise fundamentada na modalidade de tradução empregada. As modalidades desse estudo são baseadas nos conceitos originais de Vinay \& Darbelnet $(1958,1977)$, porém modificadas através de contribuições de Váquez-Ayora (1977), Barbosa (1990, 2004) e Aubert (1984, 1998, 2005a). Estas modificações são detalhadas na seção 3.3. O segundo é classificação através de graus de aproximação, descritos na seção 3.4. O grau de aproximação classifica as soluções com base na aproximação do receptor (leitor) ao texto original.

\subsubsection{Marcadores culturais}

Os trechos estudados não foram escolhidos aleatoriamente. Nas palavras de Aubert (2005b):

Nos estudos lingüístico-descritivos que abordam os processos tradutórios e seus produtos, os textos traduzidos, é freqüente a remissão a questões de ordem cultural. Subjaz a tal remissão um conjunto de hipóteses que, na essência: (a) concebem cada língua e cada ato de fala como portadores de marcas culturais; (b) identificam tais marcas culturais como colocando desafios significativos à consecução do ato tradutório; e, por conseguinte, (c) prevêem que as marcas culturais presentes nos textos originais darão ensejo a comportamentos tradutórios específicos, diversos - em natureza ou em distribuição - àqueles encontradiços nos segmentos de texto não marcados culturalmente.

A tradução jurídica exige pesquisa jurídica e lingüística para a tradução fiel de elementos culturais como (1) instituições e conceitos dos respectivos sistemas jurídicos e sua administração e (2) termos e frases jurídicos que representam a maneira de falar e de pensar 
no universo jurídico do idioma/cultura original. Um dos objetivos deste estudo foi identificar estes marcadores culturais (ou indicadores de alteridade) e observar como foram traduzidos no corpus de estudo. Procurei marcadores culturais com ocorrência elevada e em certas áreas temáticas, para enriquecer a análise através de comparação de soluções de tradutores diferentes do mesmo marcador ou do mesmo tipo de marcador. Busquei marcadores culturais tanto nos originais quanto nas traduções, e portanto em alguns casos trechos que não aparentem conter marcadores culturais são traduzidos por trechos que contêm algum marcador. Muitos exemplos com apenas uma ocorrência foram omitidos devido a limitações de espaço.

Muitos dos marcadores culturais são expressões intralingualmente marcadas, pois assinalam o texto como integrante da linguagem jurídica da língua em questão. Para o fim deste estudo, vou separar os marcadores em dois tipos: referenciais (extra-linguísticos), que provêm dos conceitos jurídicos, agências, departamentos, processos, etc. diversos nos dois países; e estilísticos, que são maneiras de falar (convenções), freqüentemente devidas a práticas antigas ainda em uso.

\subsubsection{Descrição dos corpora}

No âmbito do presente projeto, foquei somente a área jurídica privada, especificamente documentos constitutivos, contratos entre empresas ou entre empresas e pessoas físicas e procurações. Não foram incluídos documentos atinentes à área penal, documentos pessoais (casamento, nascimento, testamentos etc.), nem o universo multifacetado dos direitos humanos. São dois corpora paralelos com originais e suas traduções (um corpus de originais em português e um corpus de originais em inglês) e dois corpora comparáveis (um de documentos originais em inglês, sem traduções correspondentes, e outro de documentos originais em português, também sem traduções). Os corpora e suas interligações estão apresentados na figura 1.2. 


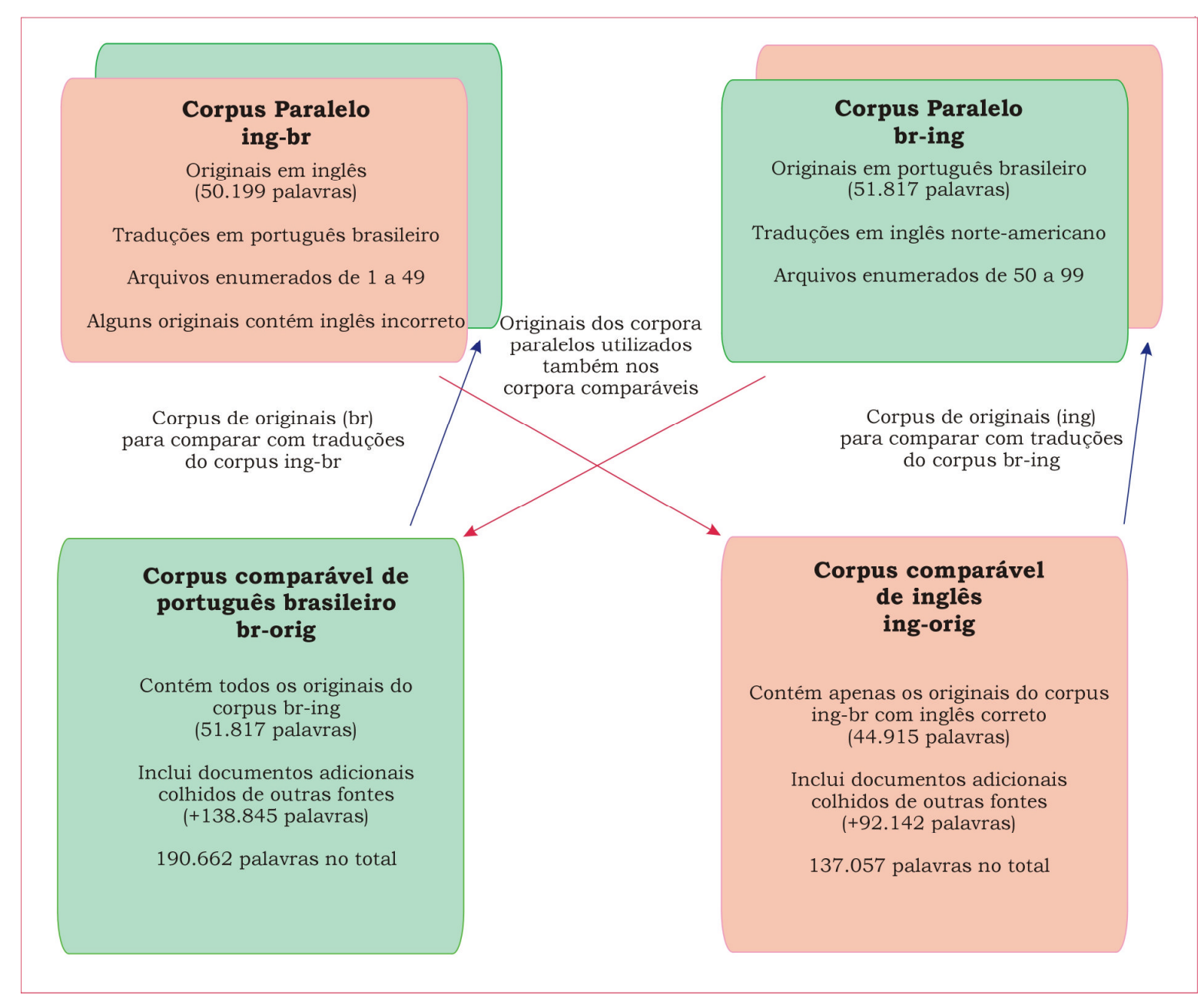

Figura 1.2 - Corpora paralelos e comparáveis

Utilizei ferramentas de corpus para facilitar a análise (veja a seção 4.5 para mais detalhes). Quando encontrei um termo ou expressão de interesse, foi possível buscar o termo em todos os corpora ao mesmo tempo, tanto nos originais quanto nas traduções. Assim podia me concentrar na análise dos resultados e não na mecânica da busca. Os corpora comparáveis foram utilizados para comparação com as traduções dos corpora paralelos, para questões relacionadas à normalização das traduções para se assemelharem a originais na língua de chegada. 


\subsubsection{Contexto sociocultural}

Não existe só um estilo ou tipo de tradução jurídica. Nem só duas (juramentada e não juramentada). Há muitos motivos para traduzir um documento jurídico e todos eles são válidos. Em quais situações um documento jurídico estrangeiro deve permanecer claramente estrangeiro, e como esse objetivo é atingido? Inspirada no trabalho de Holz-Mänttäri sobre Translational Action como descrito em Munday (2001, p. 77-78), criei categorias para descrever as possíveis motivações dos atores envolvidos, ou seja, o motivo por que a tradução foi encomendada, por que o documento original foi escrito, e os leitores esperados do texto original e da tradução. Estas categorias são descritas na seção 3.4.

\subsubsection{Análise qualitativa}

Não foi o objetivo deste estudo criar estatísticas exatas de todas os marcadores culturais do corpus. Portanto, as freqüências de ocorrência são apenas para revelar tendências e não para servir como uma amostra típica ou representativa das traduções dos marcadores. Foram escolhidas na base de múltiplas ocorrências ou na base de se enquadrarem em uma ou outra categoria de marcadores (terminologia jurídica, qualificações, etc.). A análise é principalmente qualitativa.

Para cada arquivo, temos os seguintes dados:

- o tradutor (identificado por uma letra)

- a língua de domínio mais ativo do tradutor

- o sentido da tradução (para inglês ou para português)

- se a tradução foi juramentada ou não

- a situação tradutória

E para cada exemplo, temos os seguintes dados adicionais:

- $\mathrm{a}(\mathrm{s})$ modalidade(s)

- o tipo de marcador, e o sub-tipo (jurídico, financeiro, etc.)

- $\quad$ o grau de aproximação. 
As freqüências de ocorrência para cada conjunto de parâmetros serão compiladas e analisadas nos capítulos 5, 6 e 7 .

\subsection{Estudos anteriores}

Zanotto (1993) utilizou o modelo de Aubert (1984) para classificar as soluções tradutórias para todas as palavras em 6 textos representando 3 gêneros. Dois dos textos eram documentos jurídicos, especificamente um contrato social e um contrato de prestação de serviços. $\mathrm{O}$ resultado desse cotejamento é apresentado na Tabela 1.1 .

\begin{tabular}{|l|c|c|}
\hline $\begin{array}{c}\text { Modalidade / } \\
\text { percentagem }\end{array}$ & $\begin{array}{c}\text { Textos } \\
\text { referenciais } \\
\text { (jurídicos) }\end{array}$ & $\begin{array}{c}\text { Textos } \\
\text { normativos, } \\
\text { expressivos e } \\
\text { referenciais }\end{array}$ \\
\hline omissão & 0,28 & 0,17 \\
\hline empréstimo & 3,69 & 2,53 \\
\hline tradução literal & 45,64 & 42,81 \\
\hline transposição & 22,67 & 22,41 \\
\hline explicitação & 11,99 & 11,87 \\
\hline modulação & 14,69 & 18,51 \\
\hline outros & restante & restante \\
\hline
\end{tabular}

Tabela 1.1 - Resultados de Zanotto (1993)

Nesse estudo, a unidade de estudo foi a palavra. A percentagem de tradução literal mais transposição chega próxima a $70 \%$.

O estudo de Camargo (1998), também baseado nas modalidades de Aubert (1984) estudou 4 tipos de textos: jurídicos, técnicos, corporativos e jornalísticos. Os resultados para os textos jurídicos e para o corpus como um todo são apresentados na tabela 1.2. 


\begin{tabular}{|c|c|c|c|}
\hline \multicolumn{2}{|l|}{ Textos Jurídicos } & \multicolumn{2}{|c|}{ Todos os Textos } \\
\hline modalidade & $\%$ & modalidade & $\%$ \\
\hline tradução literal & 37,7 & $\begin{array}{l}\text { tradução } \\
\text { literal }\end{array}$ & 40,9 \\
\hline transposição & 26,4 & transposição & 27,7 \\
\hline modulação & 17,9 & modulação & 15,0 \\
\hline $\begin{array}{l}\text { transposição } \\
+ \text { modulação }\end{array}$ & 5,5 & $\begin{array}{l}\text { transposição } \\
+ \text { modulação }\end{array}$ & 4,0 \\
\hline transcrição & 4,8 & transcrição & 2,9 \\
\hline empréstimo & 2,1 & $\begin{array}{l}\text { explicitação/ } \\
\text { implicitação }\end{array}$ & 2,6 \\
\hline $\begin{array}{l}\text { transposição } \\
+ \text { empréstimo }\end{array}$ & 1,3 & & \\
\hline outros & restante & outros & restante \\
\hline
\end{tabular}

Tabela 1.2 - Resultados de Camargo (1998)

Neste estudo, a percentagem de "tradução literal" mais "transposição" é cerca de 64\%. Camargo observa

"Como era de se esperar, a amostra dos textos jurídicos parece solicitar dos tradutores um maior emprego da modulação do que as dos textos técnico e corporativo, na medida em que se supõe a linguagem do Direito ser mais elaborada e menos previsível do que a utilizada na tecnologia e nas empresas." (Camargo, 1998)

Apesar das diferenças quantitativas entre esses dois estudos, é aparente que as três modalidades mais utilizadas na tradução jurídica são tradução literal, transposição e modulação. A diferença principal entre esses estudos e o presente estudo é que não analiso a 
tradução de todas as palavras no corpus, somente as soluções tradutórias de marcadores culturais. Espera-se um número maior de modulações, explicitações e empréstimos nesse caso.

Estudos baseados no mesmo conceito de cotejamento de todas as palavras em um ou mais textos também foram feitos sobre várias obras literárias e tradução de e para português. Aubert (2003) cita vários desses estudos e resume seus resultados.

Matthews (2003), em sua tese de doutorado, analisa um corpus de documentos jurídicos do Tratado Norte-Americano de Livre Comércio. Ela classifica as unidades de estudo escolhidas por procedimentos (utilizando os procedimentos de Vinay e Darbelnet com algumas modificações) e também se a tradução foi literal ou livre (formal ou funcional). Ao contrário dos estudos citados acima, ela escolhe segmentos de texto para análise, unidades de tradução maiores do que a palavra, mas a escolha não é orientada por nenhuma diretriz específica.

Os procedimentos que ela utiliza para classificar as traduções refletem algumas modificações sobre os de Vinay e Darbelnet, com a alteração principal no procedimento equivalência.

[Vinay et Darbelnet] appellent équivalence la traduction des proverbes, des clichés et des idiotismes par des proverbes, des clichés et des idiotismes équivalents dans la langue d'arrivée. Toutefois, [ici], l'équivalence n'est pas utilisée au sens que Vinay et Darbelnet lui assignent; elle désigne plutôt la traduction des termes propres à un domaine de spécialité par les termes équivalents utilisés dans la langue d'arrivée. Matthews (2003, p. 195)

O resumo dos dados de Matthews está na tabela 1.3.

\begin{tabular}{|l|l|l|}
\hline Procedimento & Inglês para francês & Inglês para espanhol \\
\hline Equivalência & $45 \%$ & $26 \%$ \\
\hline Modulação & $80 \%$ & $18 \%$ \\
\hline
\end{tabular}




\begin{tabular}{|l|l|l|}
\hline Tradução Literal & $16 \%$ & $84 \%$ \\
\hline Transposição & $41 \%$ & $20 \%$ \\
\hline
\end{tabular}

Tabela 1.3 - Resultados de Matthews (2003, p. 184)

Estas percentagens são baseadas em 87 unidades de estudo (tanto para a tradução para francês quanto para a tradução para espanhol). As percentagens não somam $100 \%$ porque o estudo admite mais de um procedimento para a mesma unidade de estudo. Eu omiti as percentagens dos outros procedimentos para facilitar a comparação.

Alves (2005), em sua dissertação de mestrado, analisou as versões para francês por 13 tradutores juramentados do mesmo histórico escolar brasileiro. Ela analisa as traduções linha por linha, e utiliza as modalidades definidas por Aubert (2005a) na análise qualitativa das traduções, mas sem tentar fazer um cotejamento palavra-por-palavra nem criar uma tabela de freqüências.

\subsection{Estrutura desta tese}

O próximo capítulo, capítulo 2, apresenta algumas informações explicativas sobre a sub-área jurídica tratada neste estudo. Os tipos de documentos presentes no corpus serão descritos, além de um breve detalhamento dos tipos de sociedades no Brasil, nos EUA e na GrãBretanha. O capítulo 3 fornece a fundamentação teórica para o restante do estudo, com uma curta história das discussões sobre tradução, e depois dos modelos relevantes ao modelo desenvolvido aqui. O capítulo 4 delineia a metodologia empregada neste estudo, desde o projeto dos corpora ao seu levantamento, descrição e análise. Os capítulos 5 e 6 analisam os marcadores referenciais e estilísticos, respectivamente, de maneira qualitativa e quantitativa. Finalmente, capítulo 7 apresenta as conclusões baseadas nessas análises. O apêndice contém um resumo dos dados descritivos para cada exemplo (listados na seção 1.2.4 acima). 


\section{Universo da pesquisa}

O universo deste estudo é o universo jurídico e seus discursos. O direito brasileiro segue a tradição civil romana, enquanto o direito norte-americano e o britânico seguem o sistema chamado de "common law". Neste capítulo, apresentarei um breve resumo das duas tradições jurídicas, seguido por uma descrição de quatro aspectos relacionados aos gêneros específicos dos documentos dos corpora. Estes aspectos são a estrutura da procuração, os tipos de sociedades existentes no Brasil, nos EUA e na Grã-Bretanha, a estrutura de atos constitutivos e a estrutura de contratos.

\subsection{Histórico do universo jurídico no Brasil, nos EUA e na Grã-Bretanha}

O livro "Comparative Legal Traditions" de Glendon (1999) descreve as fundações das tradições de direito civil e common law.

\subsubsection{A tradição de direito civil}

Não existe "um" direito romano, pois o império existiu por séculos. O que sobreviveu foi a compilação feita pelo Imperador Justiniano do Império Bizantino no sexto século dC. Esta compilação, chamada de Corpus Juris Civilis foi baseada em livros jurídicos da época, hoje perdidos. Foi apenas no século XI que o ocidente voltou a incorporar o direito romano na lei regional—no meio tempo, os costumes regionais foram seguidos, às vezes com alguma influência do direito romano.

No século XIII, estudiosos do norte da Itália estudaram o Corpus Juris Civilis, procurando entender os raciocínios que o subjazeram, e aplicar as idéias à situação daquela época. Nos séculos seguintes, a lei civil se tornou a lei comum "jus commune" da Europa (que não deve ser confundida com "common law", que é um outro conceito). Esse jus commune incluiu principalmente direito privado e não o público ou criminal. 
Com a criação de nações e do direito nacional, cada país desenvolveu seu próprio código baseado na mistura única do direito romano e do direito medieval da sua região e da sua cultura. Foi nessa época que as leis foram codificadas na Europa. O Código Civil francês (1804) e o Código Civil alemão (1896) serviram de modelo para a maioria dos outros. Enquanto o Código da França tinha um estilo simples, para ser lido e entendido pelo cidadão, o Código alemão tinha um estilo mais rebuscado, definiu muita terminologia nova e foi escrito para ser lido por advogados e juristas. O Código Civil brasileiro foi influenciado mais pelo Código francês. O Código Civil brasileiro atual (chamado de Novo Código Civil ou Lei 10.406/02) é de janeiro de 2002. O Código Civil anterior era de janeiro de 1916.

O direito brasileiro é dividido em direito público e privado. O direito privado é dividido em direito civil, direito comercial e direito do trabalho. Os documentos dos corpora são de direito privado, e incluem procurações, contratos e estatutos sociais e contratos (inclusive um contrato de trabalho). A maioria da legislação pertinente a esses documentos está contida no Código Civil. A árvore de domínio apresentada na figura 2.1 é derivada de Martins (2006, p. $10)$.

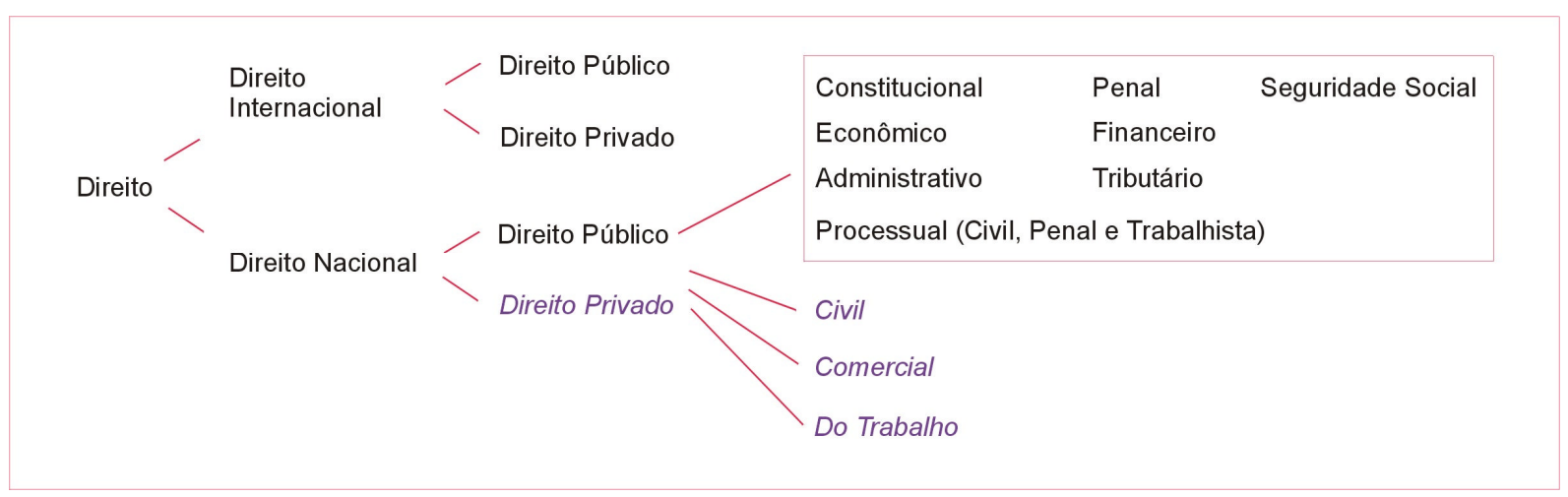

Figura 2.1 - Árvore de domínio

\subsubsection{A tradição de common law}

O direito britânico ("common law") evoluiu das necessidades da administração de Guilherme, o Conquistador após a conquista Normanda em 1066. A lei foi baseada em uma constituição 
verbal e nas opiniões orais (e depois registradas) de juízes. Assim começou o conceito de direito por precedente judicial. Este sistema funcionou em parte porque a sociedade era homogênea e sem invasão por quase 1000 anos. O sistema jurídico sob Guilherme foi muito centralizado. Os tribunais locais ainda existiam, às vezes com sobreposição de jurisdição. Porém, o público geralmente preferia os tribunais do novo sistema, pois os consideraram mais justos. A Magna Carta em 1215 foi um tipo de constituição e incluiu algumas declarações que protegeram cidadãos comuns. Os tribunais antigos sumiram com o passar do tempo.

No século XVIII, um professor de direito em Oxford, William Blackstone, escreveu "Commentaries on the Laws of England" em um estilo acessível e conciso. Este livro se tornou muito popular e sua primeira edição nos EUA foi em 1771. Esse livro teve um impacto enorme na lei do novo país. Há codificação de algumas leis nos países de common law, mas mesmo assim a interpretação dos estatutos é orientada por precedente.

Como a lei em países com a tradição de "common law" é apenas parcialmente codificada, as divisões não são tão bem definidas nessa tradição quanto na tradição civil. Um fator importante são os vários níveis de leis (local, estadual/regional e federal). Nos EUA, é a lei estadual que rege procurações, contratos, e a constituição de sociedades, apesar de haver uma tentativa de padronização entre estados para facilitar o comércio entre eles. As leis no Reino Unido também são freqüentemente locais ou regionais.

Além de dividido em lei estadual/regional e lei federal, a lei divide-se em "civil law" e "criminal law". A diferença principal entre as duas é que o réu em um processo de "criminal law" pode ser punido por encarceramento. Basicamente, como a "lei" depende de precedentes judiciais em vez de estatutos (na maioria das vezes) e como se desenvolveu durante séculos, a ênfase é nas categorias mais próximas ao usuário (p.ex. procuração) sem um esquema geral para organizar os conceitos. Muitos assuntos são tratados tanto pela lei federal quanto pela lei estadual/regional. 
Os documentos deste corpus foram escolhidos baseados na árvore de domínio para a lei brasileira, mas se encaixam na área de civil law, e na categoria de lei estadual/regional.

\subsection{Aspectos discursivos e lingüísticos da procuração}

Tanto em inglês quanto em português, os instrumentos de procuração tendem a ater-se a alguns poucos padrões discursivos e fraseológicos. À guisa de ilustração preliminar, apresento nas seções abaixo alguns exemplos, acompanhados de comentários.

\subsubsection{Aspectos discursivos e lingüísticos da procuração norte-americana e britânica}

Há três principais tipos de procuração nos EUA/GB: general power of attorney (com poderes plenos e gerais), special power of attorney (com poderes específicos) e durable/enduring power of attorney. Um exemplo do general power of attorney é apresentado na figura 2.2 e do durable power of attorney na figura 2.3 .

\section{GENERAL POWER OF ATTORNEY}

2 This General Power of Attorney is made this day of

3 by [full name] of [full address].

4 I appoint [full name and address] to be my attorney in accordance with section 10 of the Powers of Attorney Act 1971.

5 IN WITNESS whereof I have hereunto set my hand the day and year first above written.

6 SIGNED as a Deed and Delivered by the said

7 [signature]

8 in the presence of [name and address of witness]

(301 Legal Forms, 2002)

Figura 2.2 - General Power of Attorney

\section{DURABLE POWER OF ATTORNEY}

2 I, [name of person giving the power of attorney], of [city and state] hereby appoint [name of person to whom the power is given] of [city and state], as my true and lawful attorney- 
in-fact for me and in my name to act in my capacity to do any and all of the following:

3 [list special duties or powers that the attorney-in-fact is empowered to do on behalf of the principal.]

4 This instrument is to be construed and interpreted as a durable power of attorney and any subsequent incapacity of the principal shall not affect this power of attorney.

5 The rights, powers, and authority granted to my attorney-in-fact shall be effective on the date this document is signed and delivered to the attorney-in-fact and shall remain in effect unless sooner canceled by me until [date].

6 Dated:

7 [signature]

8 [acknowledgment]

(Roberson, 1994, p. 478)

Figura 2.3 - Durable Power of Attorney

Fraseologias com múltiplas maneiras de dizer a mesma coisa são muito comuns na linguagem jurídica em inglês. Um exemplo disso é "for me and in my name to act in my capacity" na linha 2 (figura 2.3) e "the rights, powers and authority" na linha 5 (figura 2.3).

\subsubsection{Aspectos discursivos e lingüísticos da procuração brasileira}

Os conceitos de mandato e mandato judicial são tratados no código civil (Fiuza, 2006, arts. 653 e 692, respectivamente). Um exemplo de procuração é apresentado na figura 2.4 abaixo.

2 Por este instrumento particular (nome, qualificação, endereço e número do CPF), ao final assinado, nomeia e constitui seu bastante procurador (nome, qualificação, endereço e número do $\mathrm{CPF}$ ), a quem confere poderes para o fim especial de representar o outorgante quando da lavratura de uma escritura de compra e venda de um imóvel, situado nesta cidade, à Rua......, adquirido pelo outorgante de e sua mulher imóvel esse que se encontra livre e desembaraçado de quaisquer ônus. 
3 Confere, ainda, poderes ao outorgado para que esse aceite e assine a respectiva escritura, que será lavrada no Cartório da Comarca de........, podendo, ainda praticar todos os demais atos que forem e se fizerem necessários ao fiel cumprimento deste mandato.

4 Por ser verdade firmo o presente para que surta seus efeitos de direito.

5 (local e data)

6 (assinatura do outorgante com firma reconhecida)

(Parizatto, 2006, p. 212)

Figura 2.4 - Procuração para Compra de Bem Imóvel

O mandato judicial se opera por procuração ad judicia. Este tipo de procuração é substituído nos EUA pelo Legal Services Retainer Agreement. Um exemplo de uma procuração ad judicia é apresentado na figura 2.5 .

2 (nome, qualificação e endereço), ao final assinado, portador do RG n. ${ }^{\circ}$...... e do CPF n. ${ }^{o}$......, pelo presente nomeia e constitui seu bastante procurador (nome e qualificação), advogado, inscrito na $\mathrm{OAB}$ sob o n. ${ }^{\circ}$........ Seção de ........, com escritório situado à rua......, em..........., onde recebe intimações e avisos, a quem confere os poderes para o foro em geral, com a cláusula "ad judicia”, em qualquer Juízo, Instância ou Tribunal, podendo propor contra quem de direito as ações competentes e defendê-lo nas contrárias, seguindo umas e outras, até final decisão, usando os recursos legais e acompanhando-os, conferindo-lhe, ainda, poderes especiais para confessar, desistir, transigir, firmar compromissos ou acordos, receber e dar quitação, agindo em conjunto ou separadamente, podendo, ainda substabelecer esta em outrem, com ou sem reserva de poderes, dando tudo por bom, firme e valioso, especialmente para

3 (local e data)

4 (assinatura do outorgante)

(Parizatto, 2006, p. 217)

Figura 2.5 - Procuração Ad Judicia 
Observe que o exemplo da figura 2.5 consiste em somente um período, um padrão comum.

\subsubsection{Semelhanças e diferenças nos aspectos discursivos e lingüísticos de procurações}

Observe que nas procurações norte-americanas (linhas 3 e 4 da figura 2.2 e linha 2 da figura 2.3) não é comum descrever os indivíduos através de seus números identificadores, estado civil e profissão, como nas procurações brasileiras (linha 2 da figura 2.4 e linha 2 na figura 2.5). Todas as procurações no corpus ing-br foram originariamente elaboradas no Brasil ou foram inspiradas no modelo brasileiro com vistas à sua tradução e validação no Brasil, razão pela qual contêm os dados descritivos completos. A procuração é muito menos utilizada nos EUA (onde a burocracia é menor e não há o conceito de cartório) e por isso procurações originalmente escritas nos EUA são muito menos encontradas e traduzidas.

Uma característica não só de procurações, mas também de contratos e atos constitutivos brasileiros é a maneira de apresentar os números identificadores de indivíduos e sociedades (da Figura 2.5):

portador do RG n. ${ }^{\circ} . . . .$. e do CPF n. ${ }^{o} . . . . .$.
inscrito na OAB sob o n. ${ }^{\circ}$........ Seção de ........

Não há fraseologias análogas no inglês, mas traduções consagradas já existem no Brasil, um tipo de interlíngua desenvolvida para traduzir conceitos brasileiros para o inglês da maneira mais direta possível. "Portador do" é freqüentemente traduzido como "Bearer of", e "inscrito na" é freqüentemente traduzido como "enrolled in".

Um outro aspecto de interesse é o binômio "nomeia e constitui" (linha 2 da figura 2.4 e linha 2 da figura 2.5) para indicar o procurador e estabelecer seus poderes. No inglês, o verbo "appoint" (linha 4 da figura 2.2 e linha 2 da figura 2.3) é utilizado para este fim. Aliás, mais adiante na procuração na figura 2.3 (linha 5) vemos a palavra "grant" utilizada para clarificar a situação. 
Uma colocação comum em procurações é "bastante procurador" (linha 2 nas figuras 2.4 e 2.5). O equivalente na procuração norte-americana é true and lawful attorney-in-fact (linha 2 da figura 2.3), attorney (linha 4 da figura 2.2) e outras alternativas como agent e attorney-infact.

\subsection{Tipos de sociedades e sua organização no Brasil, nos EUA e na Grã- Bretanha}

Os documentos em inglês são dos Estados Unidos da América e do Reino Unido. Para melhor aproveitar esses documentos durante a análise de marcadores referenciais, será necessário descrever aqui as diferenças entre a constituição de sociedades nos EUA, na Grã Bretanha e no Brasil. A legislação do Reino Unido não é uniforme, portanto vou me ater a documentos da Inglaterra e País de Gales e os tipos de sociedades nos documentos de outras partes do Reino Unido (Escócia, Irlanda do Norte, Ilhas Virgens, etc.) não serão analisados.

\subsubsection{Pessoas Jurídicas no Brasil}

O sistema brasileiro, regido pelo Novo Código Civil - Lei 10.406 de 10 de janeiro de 2002 (NCC) [versão comentada por Fiuza (2006)] e pela Lei das Sociedades Anônimas - lei 6404/76, categoriza os tipos de pessoa jurídica da seguinte maneira:

- Direito público, interno ou externo

- Direito privado

As pessoas jurídicas de direito privado são categorizadas assim:

- Associações

- Sociedades

- Fundações

- Organizações religiosas

- Partidos públicos 


\section{Categorização de sociedades}

Há várias maneiras de classificar os tipos de sociedades norte-americanos, britânicos e brasileiros:

1. Tipo de sócio / profissão dos sócios

- Todos são pessoas físicas da mesma profíssão

- Todos são de profissões de um tipo (intelectual, artístico, etc.)

- Pessoas físicas ou pessoas jurídicas e pessoas físicas

- Número de sócios (um/um casal, dois ou mais, número mínimo de sócios)

2. Se têm personalidade jurídica ou não

- Se têm (ou não) registro como entidade com o órgão competente

3. A extensão de responsabilidade dos sócios por danos e por dívidas

- Solidária e ilimitada - todos os sócios são responsáveis pelos danos causados por um sócio/empregado e por dívidas;

- Mista - só os sócios gerentes são responsáveis pelas obrigações da empresa, não os sócios investidores;

- Parcialmente limitada - os sócios não são responsáveis solidariamente pelos erros de um sócio (imperícia), mas sim pelas dívidas da empresa;

- Limitada - a responsabilidade dos sócios é limitada ao valor de sua participação.

4 Como o imposto de renda é pago

- Como pessoa física ou como pessoa jurídica

5. Finalidade

- Lucro ou sem fins lucrativos

6. Tipo de Capital Social 
- Capital aberto (ações vendidas com subscrição pública) ou fechado

Cada tipo de sociedade nos três países pode ser categorizado segundo as 6 categorias acima.

As sociedades brasileiras são divididas em dois tipos principais ( $1^{\text {a }}$ categoria acima): a sociedade simples e a sociedade empresária. Segundo o art. 967 do NCC, a sociedade empresária é a pessoa jurídica que tem por objeto o exercício de atividade própria de empresário sujeito a registro. Segundo o art. 982, se a sociedade não for empresária, será considerada como sociedade simples. Para clarificar, a sociedade simples é aquela que tem por objeto o exercício de atividade relacionada a profissão intelectual, de natureza científica, literária ou artística (NCC, art. 966, parágrafo único). Por conseqüência, o tipo de empresa depende das atividades da empresa e/ou seus sócios. Observe, porém, que a legislação que rege os dois tipos principais é quase igual. Segundo Fazzio (2004), é difícil distinguir entre sociedades simples e empresárias, "separadas hoje tão-somente pelo processo de insolvência peculiar destas (falência), já que tecnicamente incindíveis com esteio no critério da persecução de lucros." (Fazzio, 2004, p. 232)

A sociedade anônima é empresária por definição da lei, independente do objeto social. Como mostrado na figura 2.6, quatro tipos de sociedade podem ser tanto sociedades empresárias quanto sociedades simples. Os tipos remanescentes só podem ser sociedades simples.

Somente a sociedade em comum e a sociedade em conta de participação não são personificadas, ou seja, não são registradas em um órgão do governo. Os impostos são pagos através das declarações dos sócios. Todos os outros tipos são personificados. (categorias 4 e 2). A associação é o tipo principal de pessoa jurídica sem fins lucrativos (categoria 5), mas a sociedade cooperativa também é sem fins lucrativos para si mesma—os lucros são passados para seus sócios componentes. 


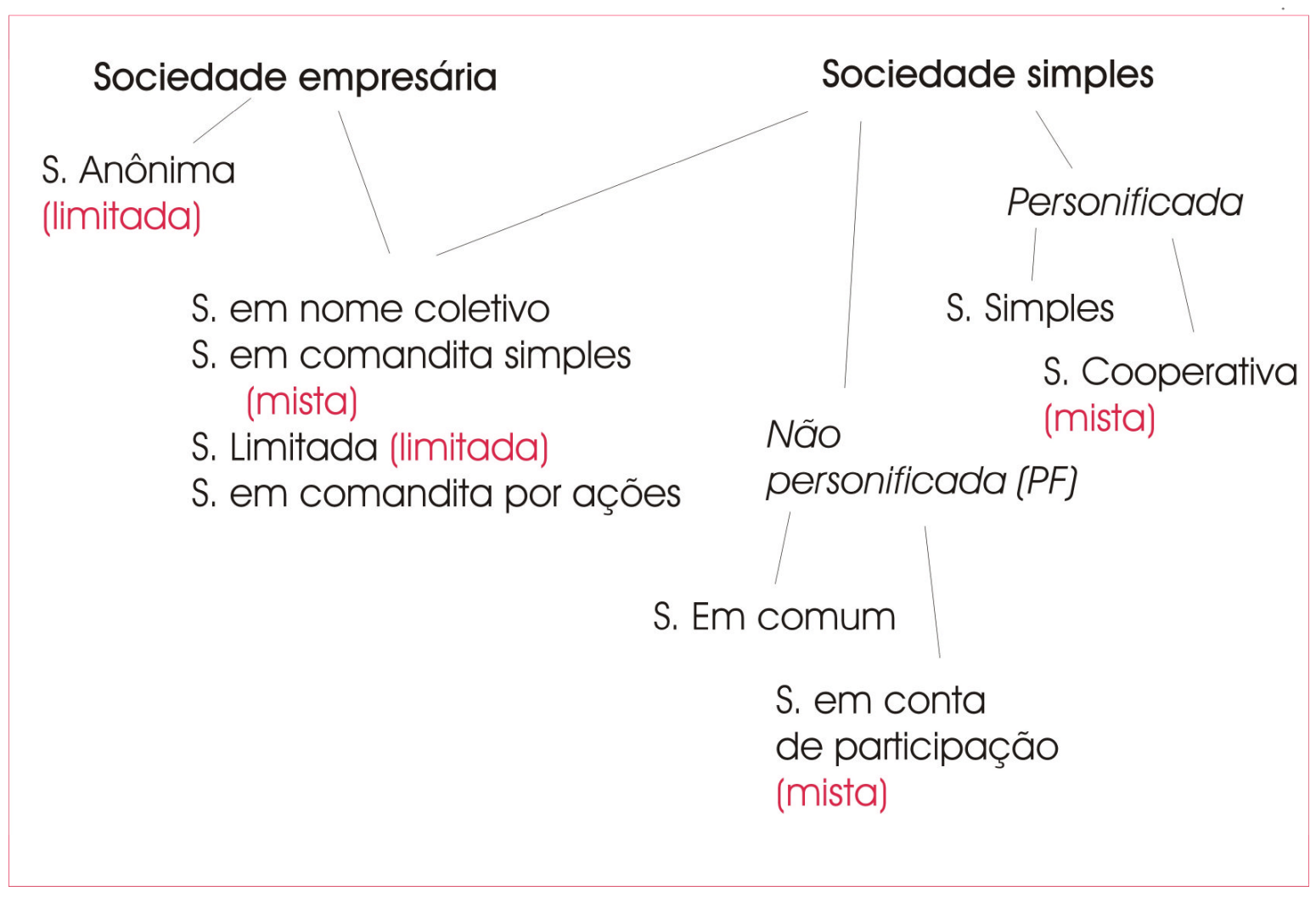

Figura 2.6 - Categorização de tipos de sociedades segundo a lei brasileira

A sociedade anônima e a sociedade em comandita por ações podem ter capital aberto ou fechado, dependendo do regime estabelecido pelos sócios. As outras sociedades só podem ter capital fechado (categoria 6).

A categoria mais complexa é a terceira - a responsabilidade dos sócios por danos e por dívidas. Os tipos de responsabilidade são resumidos na tabela 2.1.

\begin{tabular}{|c|c|c|}
\hline Solidária e Ilimitada & Mista & Limitada \\
\hline Sociedade simples & Sociedade em comandita & Sociedade anônima \\
& simples & \\
\hline Sociedade em nome coletivo & Sociedade em conta de & Sociedade limitada \\
& participação & \\
\hline
\end{tabular}




\begin{tabular}{|c|c|c|}
\hline Sociedade em comum & Sociedade cooperativa & \\
\hline & $\begin{array}{c}\text { Sociedade em comandita por } \\
\text { ações }\end{array}$ & \\
\hline
\end{tabular}

Tabela 2.1 - Tipos de responsabilidade dos sócios

As sociedades que se encaixam nas categorias mista e limitada são assim indicadas na figura 2.6, com a responsabilidade solidária e ilimitada entendida onde não houver uma observação.

Em resumo (baseado em Camargo (2004) e Fiuza (2006)):

\section{Sociedade anônima}

A empresa pode desenvolver quaisquer atividades. Tem personalidade jurídica. Cada acionista obriga-se somente pelo preço de emissão das ações que subscrever ou adquirir. A sociedade paga imposto como pessoa jurídica. Tem fins lucrativos. Pode ter capital aberto ou fechado. É definida nos artigos 1.088 e 1.089 do NCC e na lei 6.404/76.

\section{Sociedade em nome coletivo}

A empresa pode desenvolver quaisquer atividades, mas os sócios só podem ser pessoas físicas. O nome da sociedade (chamado de firma) precisa conter um ou mais nomes dos sócios. Tem personalidade jurídica. Todos os sócios respondem solidária e ilimitadamente (com seus bens particulares) pelas obrigações sociais, mas os sócios, no ato constitutivo, podem limitar entre si a responsabilidade de cada um. A sociedade paga imposto como pessoa jurídica. Tem fins lucrativos. O capital é fechado. Esta era a empresa familiar. É definida nos artigos 1.039 a 1.044 do NCC.

\section{Sociedade em comandita simples}

A empresa pode desenvolver quaisquer atividades. Tem personalidade jurídica.

É caracterizada pela existência de duas classes de sócios: comanditados (pessoas físicas responsáveis solidária e ilimitadamente pelas obrigações sociais) e comanditários (responsáveis somente pelo valor de sua quota). A sociedade paga imposto como pessoa 
jurídica. Tem fins lucrativos. O capital é fechado. É definida nos artigos 1.045 a 1.051 do NCC.

\section{Sociedade limitada}

A empresa pode desenvolver quaisquer atividades. Tem personalidade jurídica. A responsabilidade de cada sócio é restrita ao valor de suas quotas. A sociedade paga imposto como pessoa jurídica. Tem fins lucrativos. O capital é fechado. É a forma societária mais comum no país. É definida nos artigos 1.052 a 1.087 do NCC.

\section{Sociedade em comandita por ações}

A empresa pode desenvolver quaisquer atividades. Os administradores precisam ser acionistas. Tem personalidade jurídica. Os administradores respondem subsidiária e ilimitadamente pelas obrigações sociais (após esgotar os bens da empresa). A sociedade paga imposto como pessoa jurídica. Tem fins lucrativos e o capital é fechado. É definida nos artigos 1.090 a 1.092 do NCC e na lei 6.404/76.

\section{Sociedade simples}

Para empresas que desenvolvem atividades intelectuais, etc. (veja acima a discussão sobre as sociedades simples e sociedades empresárias). Tem personalidade jurídica. Os sócios respondem pelas dívidas da empresa na proporção em que participam das perdas sociais. Isso pode ser modificado no ato constitutivo através de uma cláusula de responsabilidade solidária. A sociedade paga imposto como pessoa jurídica. Tem fins lucrativos e o capital é fechado. É definida nos artigos 997 a 1.038 do NCC.

\section{Sociedade cooperativa}

A empresa pode desenvolver quaisquer atividades. Cada sócio tem só um voto durante as deliberações, independente do valor de sua participação. Os sócios podem contribuir com recursos financeiros ou com serviços. Tem personalidade jurídica. A responsabilidade dos sócios pode ser limitada ou ilimitada. Quando é limitada, o sócio responde somente pelo valor de suas quotas e pelo prejuízo verificado em sua participação nas operações sociais. Não tem fins lucrativos e o capital é fechado. É definida nos artigos 1.093 a 1.096 do NCC 


\section{Sociedade em comum}

Este tipo de empresa não tem personalidade jurídica e paga imposto como pessoa física. Os sócios respondem pelos atos de gestão praticados por qualquer dos sócios, salvo pacto expresso limitativo de poderes. Todos os sócios respondem solidária e ilimitadamente pelas obrigações sociais da empresa. Tem fins lucrativos e o capital é fechado. É definida nos artigos 986 a 990 do NCC.

\section{Sociedade em conta de participação}

Este tipo de empresa não tem personalidade jurídica e paga imposto como pessoa física. Há dois tipos de sócios: ostensivo (que representa a empresa) e participante (ou oculto), que não aparece para terceiros e é considerado somente um investidor. Salvo estipulação em contrário, o sócio ostensivo não pode admitir novo sócio sem o consentimento expresso dos demais. Somente o sócio ostensivo se obriga perante terceiros. Tem fins lucrativos e o capital é fechado. É definida nos artigos 991 a 996 do NCC.

\subsubsection{Pessoas Jurídicas nos EUA}

O direito societário é estadual nos EUA, e cada estado tem sua legislação particular para a organização de sociedades. Porém, há vários tipos de sociedade que existem (às vezes com pequenas diferenças jurídicas) em quase todos os estados. A National Conference of Commissioners on Uniform State Laws (NCCUSL) desenvolve recomendações para a governança de sociedades e os estados podem aderir $100 \%$ às recomendações ou introduzir suas modificações preferidas.

Podemos categorizar as sociedades da mesma maneira do que as empresas brasileiras para facilitar a comparação, seguindo as 6 categorias de classificação citadas acima. Essa categorização é exibida na figura 2.7. 


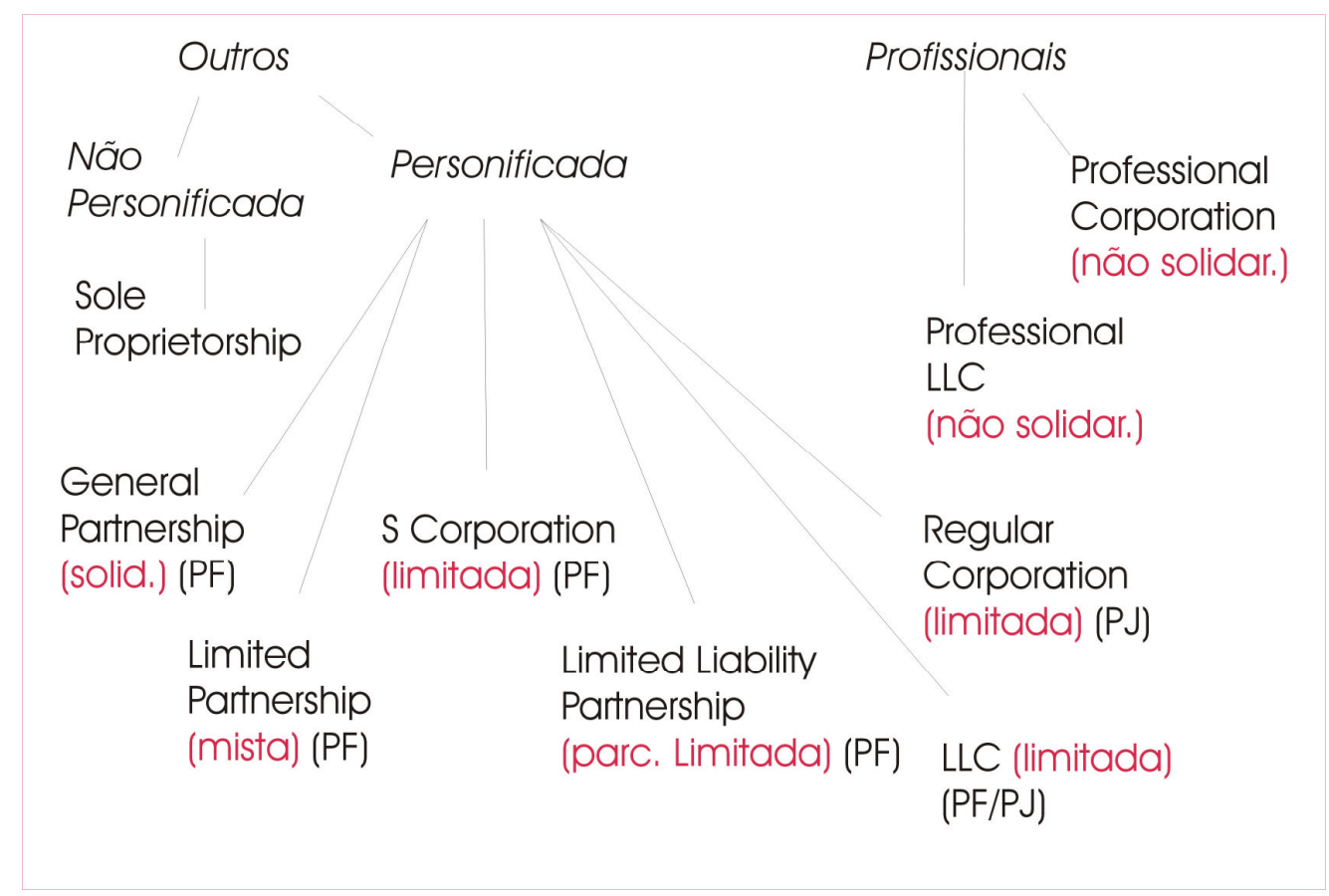

Figura 2.7 - Categorização de tipos de sociedades segundo a lei norte-americana

Há três características de destaque nas definições das sociedades norte-americanas:

1. Há alguns tipos de sociedade em que a sociedade tem personalidade jurídica, mas o imposto sobre seus lucros é pago pelos sócios em suas declarações individuais. Este é o caso com a General Partnership, a Limited Partnership, a S Corporation, a Limited Liability Partnership. Os sócios da Limited Liability Company (LLC) e da Professional LLC podem optar por pagar os impostos como pessoa jurídica ou como pessoa física.

2. Há alguns tipos de sociedade em que um sócio não é responsável pela imperícia dos outros sócios, mas em que todos são responsáveis pelas dívidas e obrigações da sociedade. Estas são as sociedades para os profissionais liberais (médicos, engenheiros, etc.) que são mais suscetíveis a processos por imperícia. Essas são as empresas profissionais na figura 2 acima: a Professional Corporation e a Professional LLC. 
3. A Sole Proprietorship, que não tem personalidade jurídica e cujo sócio precisa ser uma única pessoa física ou um casal, é mais semelhante ao profissional autônomo ou talvez à sociedade em comum com apenas um ou dois sócios.

A estrutura geral dos tipos de sociedade possíveis é a seguinte (baseado em Steingold, 2001):

\section{Sole Proprietorship}

O único sócio (ou casal) é responsável pessoalmente pelas obrigações da empresa. A empresa não tem personalidade jurídica e paga imposto de renda como pessoa física. Se não utilizar o nome da pessoa física, é necessário cadastrar o nome da entidade com um órgão estadual ou municipal (assumed name or fictitious name certificate). Tem fins lucrativos e o capital é fechado.

\section{General Partnership}

Os sócios são responsáveis pessoalmente pelas obrigações da empresa e pelas ações dos outros sócios atuando em nome da empresa. Tem personalidade jurídica, mas cada sócio paga imposto de renda como pessoa física para sua parte da renda e a sociedade faz declaração de renda para fins de informação. É comum elaborar um partnership agreement, mas pode ser oral. O capital é fechado.

\section{Limited Partnership}

Há limited partners (não administradores) cuja responsabilidade é limitada só quando não participam da gestão da sociedade, e há general partners, os sócios gerentes, que são responsáveis pelas obrigações da empresa. Tem personalidade jurídica, mas cada sócio paga imposto de renda como pessoa física para sua parte da renda e a sociedade faz declaração de renda para fins de informação. O capital é fechado. É comum para investimento em imóveis. Esse tipo de sociedade é semelhante à Sociedade em conta de participação no Brasil. 


\section{$S$ Corporation}

A responsabilidade dos sócios é limitada. Tem personalidade jurídica, mas cada sócio paga imposto de renda como pessoa física para sua parte da renda e a sociedade faz declaração de renda para fins de informação. Em alguns estados, a sociedade paga o imposto de renda como pessoa jurídica. O capital é fechado. Perdeu popularidade com a introdução da $L L C$. Os lucros e perdas da empresa são distribuídos de acordo com o número de ações de cada sócio.

\section{Limited Liability Partnership (LLP)}

Esta sociedade é geralmente só para médicos, contadores e advogados e algumas outras profissões. Os sócios são responsáveis ilimitadamente por muitas obrigações mas não são responsáveis conjuntamente pela imperícia de um dos sócios. Tem personalidade jurídica, mas cada sócio paga imposto de renda como pessoa física para sua parte da renda e a sociedade faz declaração de renda para fins de informação. O capital social é fechado. Em alguns estados pessoas jurídicas em certas profissões não podem abrir $L L C \mathrm{~s}$, e por isso existe o $L L P$ e o Professional LLC (que não existem em todos os estados).

\section{Limited Liability Company (LLC)}

A responsabilidade dos sócios é limitada, mesmo quando participam da gestão da sociedade. Um ou mais sócios podem também ser pessoas jurídicas. Tem personalidade jurídica e o imposto de renda pode ser pago como pessoa jurídica ou através das declarações particulares dos sócios (exceto no caso de um único sócio, que precisa declarar a renda da empresa em sua declaração particular). As estruturas de gerências são mais flexíveis do que as da Regular

Corporation. É possível dividir os lucros de uma maneira não paralela aos investimentos dos sócios. Seu capital é fechado.

\section{Regular Corporation}

A responsabilidade dos sócios é limitada, mesmo quando participam da gestão da sociedade. Um ou mais sócios podem também ser pessoas jurídicas. A empresa paga imposto de renda como pessoa jurídica e tem personalidade jurídica. Os lucros são passados para os sócios 
através de dividendos e salários. O capital pode ser aberto ou fechado. Pode haver três tipos de ações:

common shares - para os sócios gerentes, com direito a voto em assembléias.

nonvoting shares - para funcionários importantes, para manter fidelidade.

nonvoting preferrered shares - para investidores externos; dá preferência para dividendos e se a empresa for vendida.

\section{Professional LLC}

As regras da $L L C$ se aplicam à Professional $L L C$, mas todos os sócios precisam ter a mesma profissão.

\section{Professional Corporation (também conhecida como Personal Service Corporation)}

Todos os sócios precisam ter a mesma profissão e não são responsáveis conjuntamente pela imperícia de um dos sócios. A empresa paga imposto de renda como pessoa jurídica (com alíquota fixa) e tem personalidade jurídica. Em alguns estados, profissionais são obrigados a abrir este tipo de sociedade.

\section{Variações Estaduais nos EUA}

Ao traduzir o tipo de sociedade ou seus atos constitutivos, é importante verificar a definição do tipo de sociedade na legislação do estado em questão. Por exemplo, o estado de Vermont já avisa em seus documentos orientadores para empresários:

\footnotetext{
"There are many issues to consider before choosing one of the above three options [General, Close or Professional Corporation], $\mathrm{S}$ and $\mathrm{C}$ status for a corporation is a federal, IRS tax status. General, Professional, and Close are Vermont state-law classifications that relate to the type of corporation being formed under state law. " (State of Vermont, 2006)
} 


\subsubsection{Pessoas Jurídicas na Grã-Bretanha}

O sistema na Grã-Bretanha é semelhante ao dos EUA, e uma versão simplificada vem mostrada na figura 2.8 abaixo.

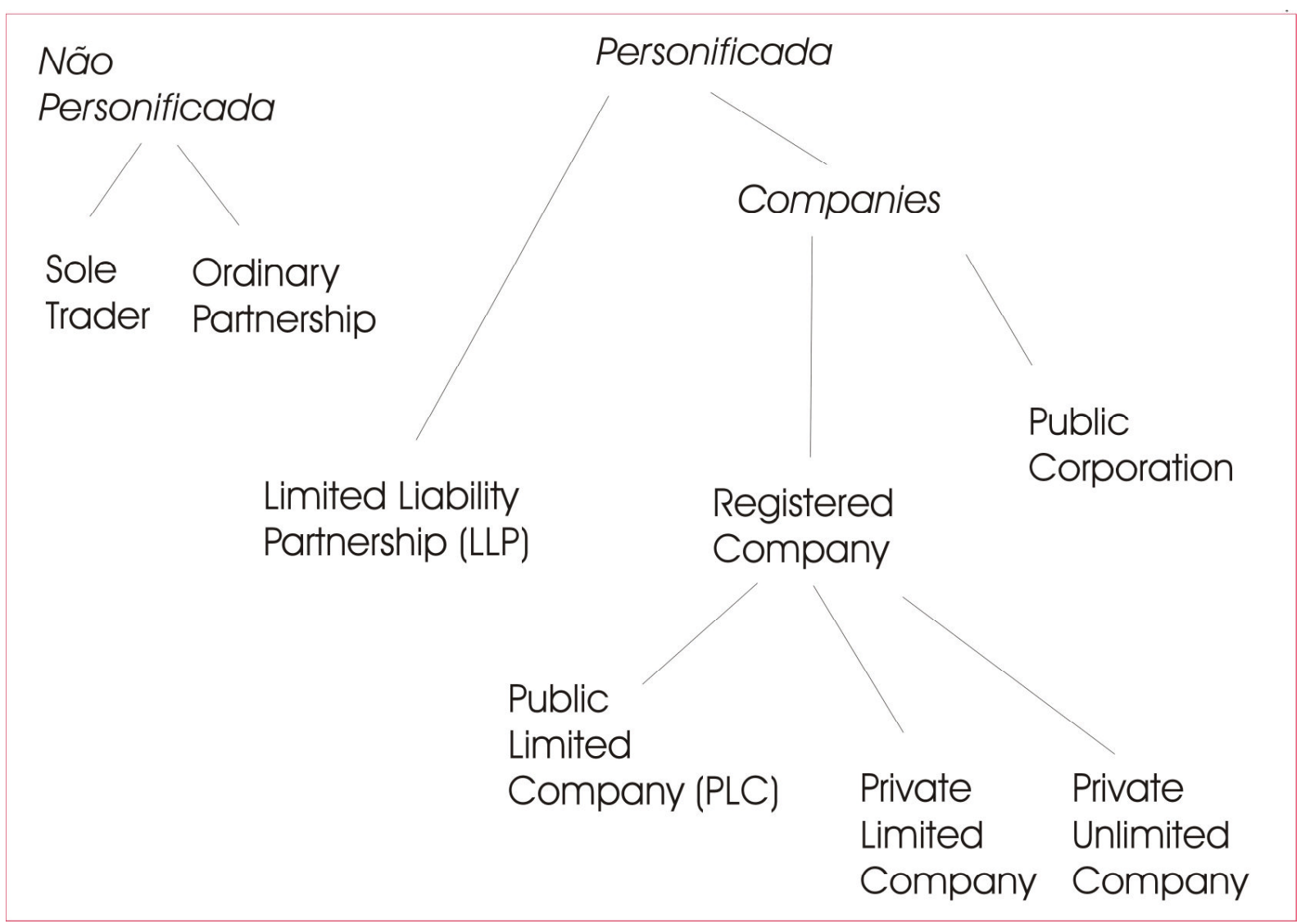

Figura 2.8 - Tipos de sociedades na Grã-Bretanha

Há dois tipos de empresas não personificadas: o Sole Trader que consiste em uma pessoa que trabalha para si mesma, e o Ordinary Partnership que, ao contrário do Partnership norteamericano, não tem personalidade jurídica. Há um Limited Liability Partnership com personalidade jurídica semelhante ao Partnership do mesmo nome nos EUA.

Uma característica terminológica interessante é que, na Grã-Bretanha, a palavra company é utilizada para descrever tanto Registered e Chartered Companies quanto Corporations. Não é 
utilizada como uma supercategoria para todo tipo de pessoa jurídica (que incluiria o sole trader e partnerships) como nos EUA. (Keenan \& Riches, 2002)

\subsubsection{Correspondências e possíveis equivalências operacionais}

Uma das dificuldades na procura de correspondências entre os tipos de empresas em sistemas jurídicos diferentes é que raramente as características principais são todas iguais. A sociedade mais simples nos EUA - o Sole Proprietorship —é mais semelhante ao profissional autônomo no Brasil (veja a figura 2.9). Nenhum dos dois é personificado, os dois pagam o imposto de renda como pessoa física e a responsabilidade do(s) sócio(s) é ilimitada (e solidária quando há dois sócios). A maior diferença é que o profissional autônomo é uma pessoa, enquanto o Sole Proprietorship pode ter como sócios uma pessoa física ou um casal.

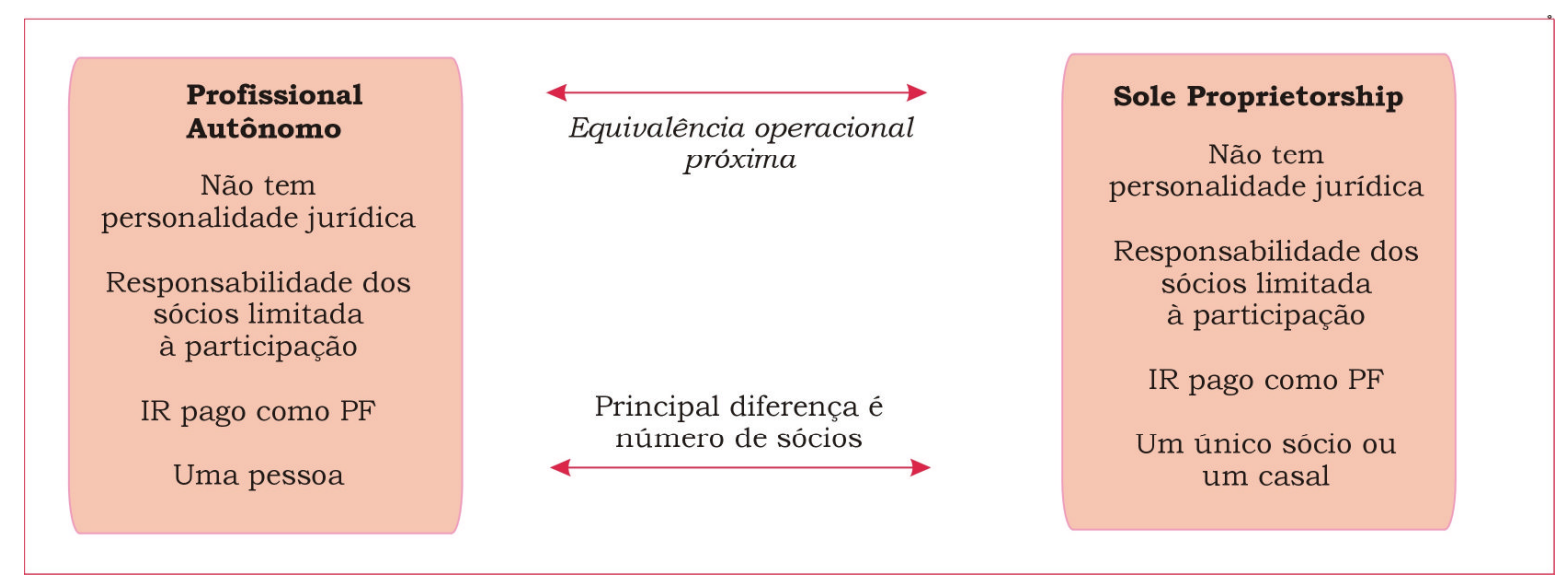

Figura 2.9 - Equivalências para o profissional autônomo

A sociedade mais popular no Brasil é a sociedade limitada. Este tipo de sociedade se assemelha bastante à Limited Liability Company (LLC) norte-americana. Ambas são personificadas, têm capital fechado, e limitam a responsabilidade dos sócios. A maior diferença operacional é que a sociedade limitada no Brasil paga imposto como pessoa jurídica, enquanto a LLC paga como pessoa jurídica ou como pessoa física (nas declarações dos sócios) dependendo da escolha dos sócios (ou em alguns casos das exigências do estado onde a LLC foi constituída). 
A LLC foi criada recentemente como uma alternativa mais flexível à $S$ Corporation, um tipo de sociedade mais antiga mas que ainda existe. A $S$ Corporation requer mais burocracia, pois emite ações e precisa seguir outras regras de corporations. Uma diferença principal entre a LLC e a $S$ Corporation é que esta paga imposto de renda como pessoa física, exceto em alguns estados onde é obrigada a pagar como pessoa jurídica. Outra diferença mais sutil é que a LLC permite mais flexibilidade na distribuição de lucros aos sócios do que a $S$ Corporation. Existe também a Professional $L L C$, que é só para a situação em que os sócios são todos profissionais de certas profissões. Estes profissionais são proibidos a abrirem uma LLC. A figura 2.10 mostra estas relações de equivalência. 


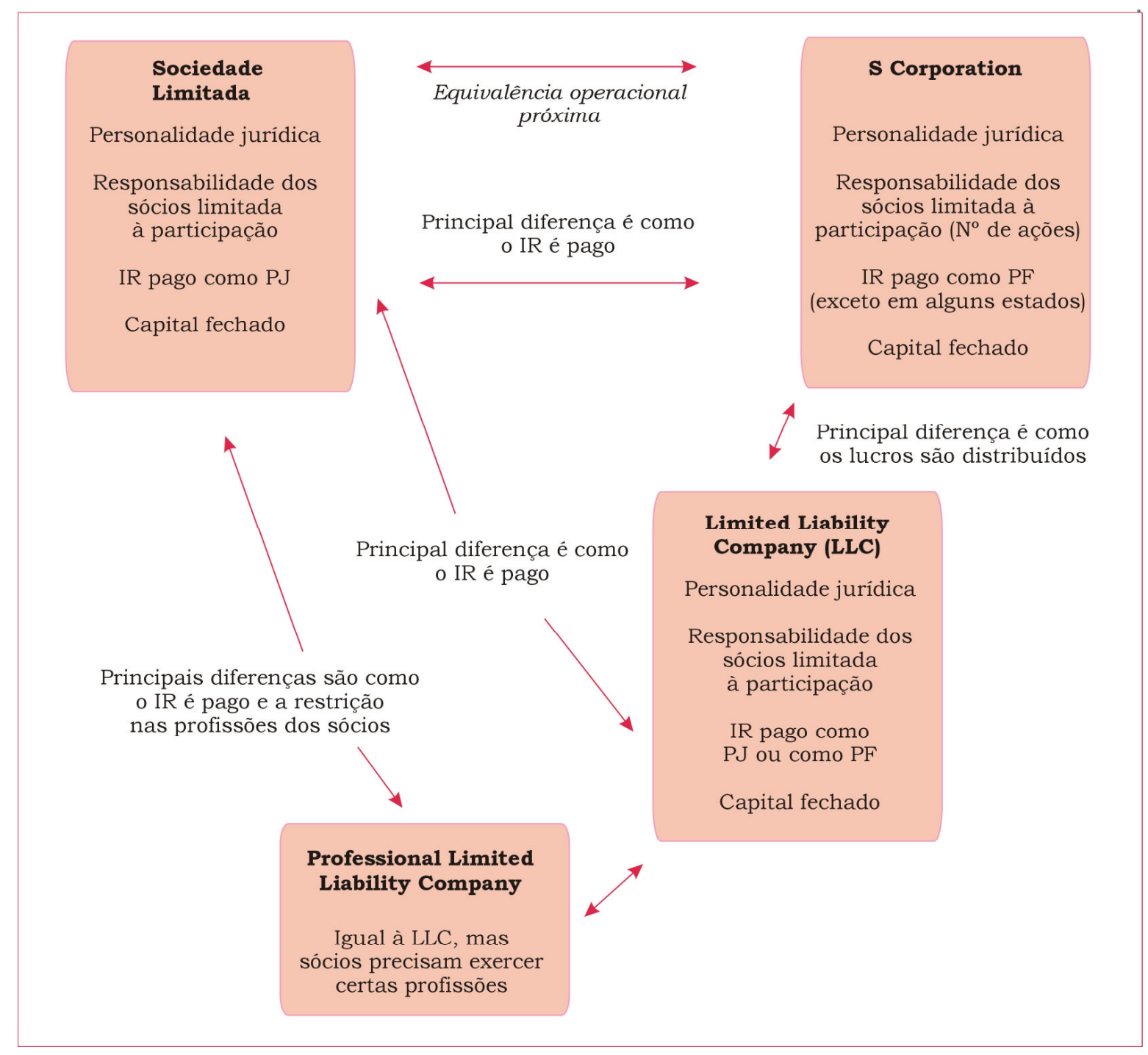

Figura 2.10 - Equivalências para a sociedade limitada

A sociedade anônima é muito semelhante à regular corporation nos EUA (veja a figura 2.11). Ambas pagam imposto de renda como pessoa jurídica, são personificadas, podem ter capital aberto ou fechado e limitam a responsabilidade dos sócios ao valor de sua participação. 


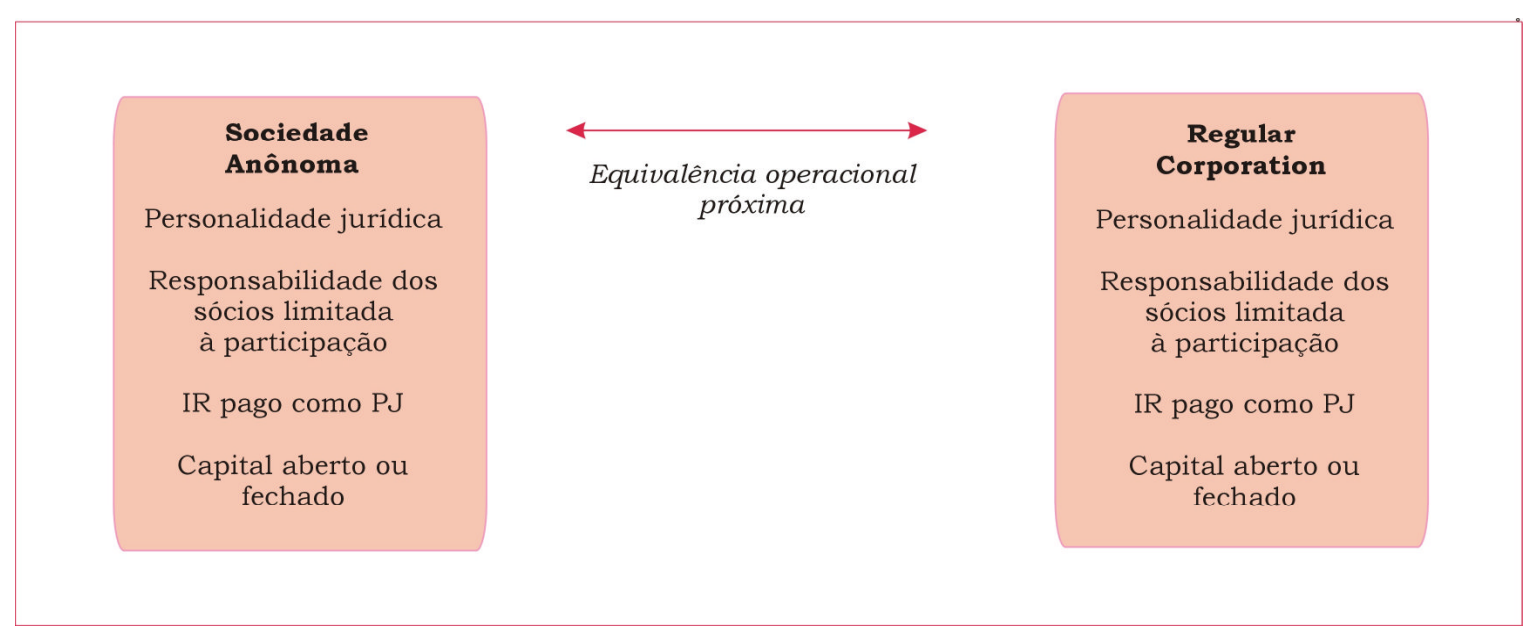

Figura 2.11 - Equivalências para a sociedade anônima

Fora a sociedade anônima, só há um tipo de sociedade nos EUA que tem duas classes de sócios - o Limited Partnership. No Brasil, há a sociedade em conta de participação, que difere do Limited Partnership por este não ter personalidade jurídica, e a sociedade em comandita simples, que tem personalidade jurídica mas paga imposto também como pessoa física, ao contrário do Limited Partnership. As equivalências são exibidas na figura 2.12. 


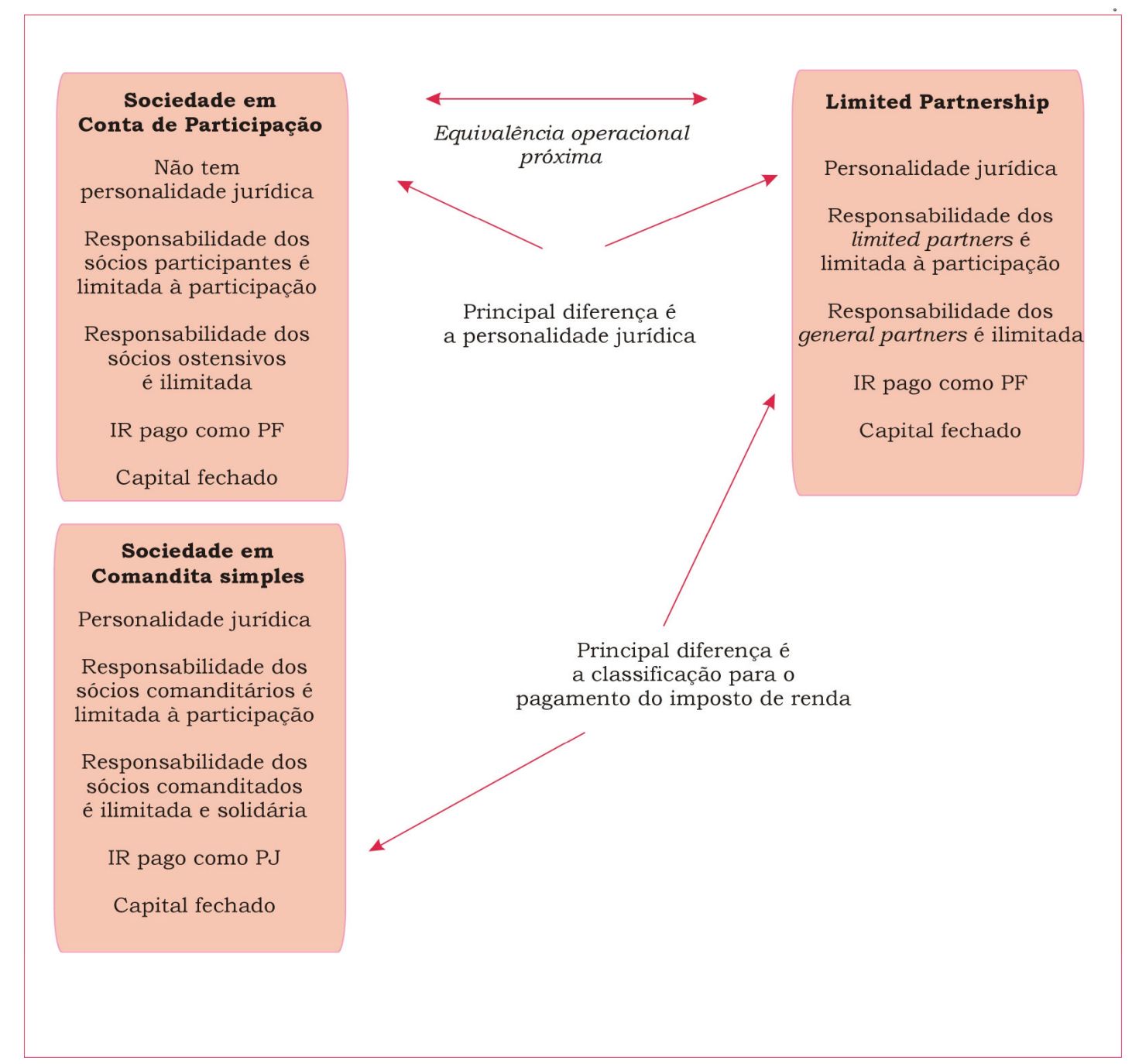

Figura 2.12 - Equivalências para a Limited Partnership

É difícil encontrar correspondências entre os tipos de sociedades remanescentes, mas a maioria delas se destaca pela responsabilidade ilimitada e solidária dos sócios. A sociedade em nome coletivo, a antiga empresa familiar, permite a limitação da responsabilidade de sócios no ato constitutivo; porém, a sociedade em comandita por ações não limita a responsabilidade dos sócios acionistas. No caso da sociedade em comum, a responsabilidade dos sócios pela gestão da sociedade é ilimitada e solidária, exceto no caso de um pacto expresso ao contrário, mas a responsabilidade pelas obrigações sociais continua ilimitada e solidária. O General Partnership norte-americano também impõe responsabilidade ilimitada e solidária aos sócios, enquanto a Limited Liability Partnership (LLP) permite uma exceção à 
responsabilidade ilimitada e solidária no caso de imperícia. Este tipo de sociedade é especificamente para certas profissões como medicina e engenharia, nas quais a imperícia é mais comum. Veja a figura 2.13 para mais detalhes das correspondências.

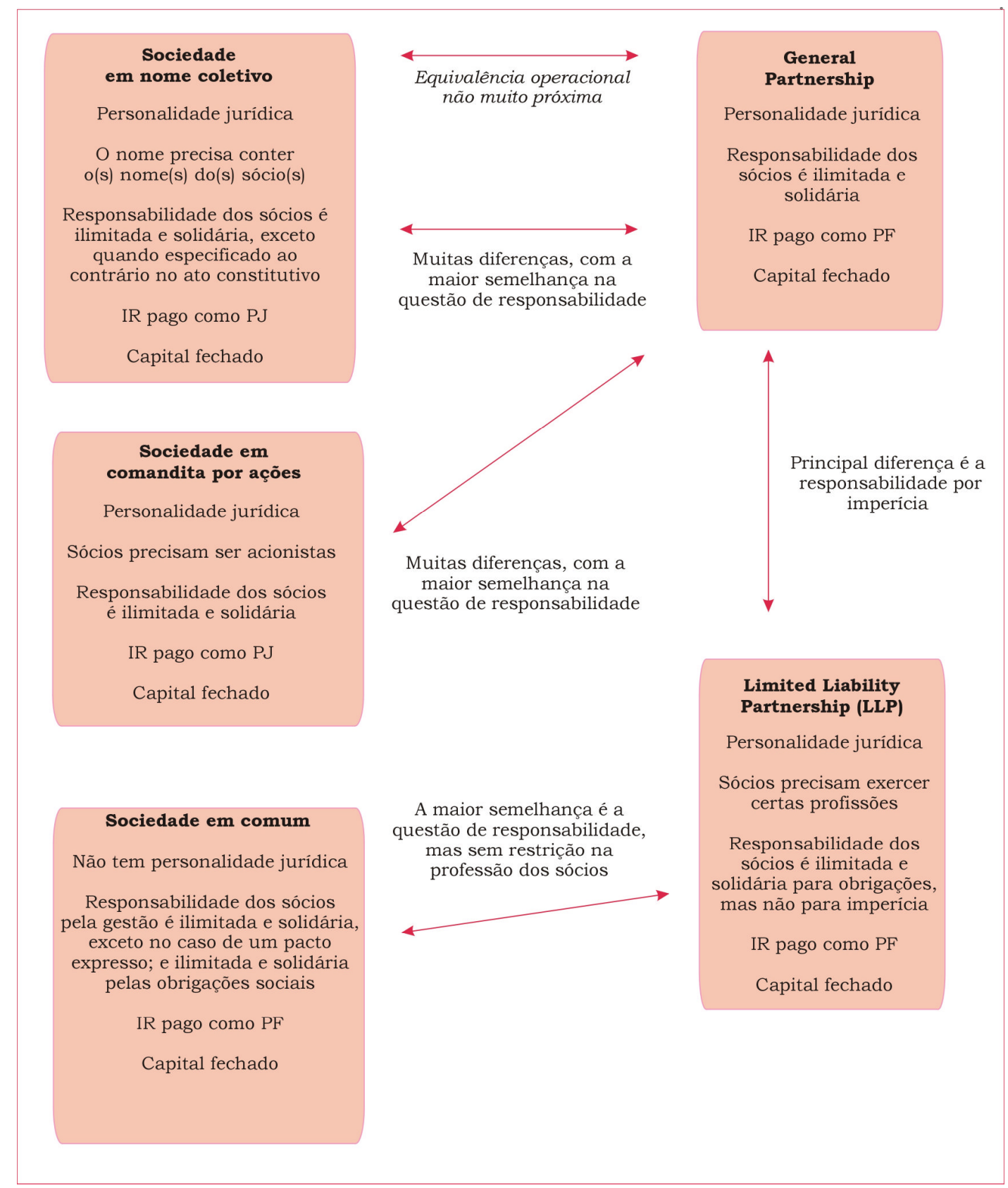

Figura 2.13 - Equivalências no caso de responsabilidade ilimitada e solidária 
Em resumo, a tabela a seguir mostra algumas possíveis equivalências operacionais:

\begin{tabular}{|l|l|}
\hline \multicolumn{1}{|c|}{ Sociedade brasileira } & \multicolumn{1}{|c|}{ Sociedade norte-americana } \\
\hline Profissional autônomo & Sole Proprietorship \\
\hline Sociedade limitada & S Corporation, LLC, Professional LLC \\
\hline Sociedade anônima & Regular Corporation \\
\hline $\begin{array}{l}\text { Sociedade em conta de participação, } \\
\text { Sociedade em comandita simples }\end{array}$ & Limited Partnership \\
\hline $\begin{array}{l}\text { Sociedade em nome coletivo, Sociedade em } \\
\text { comandita por ações, Sociedade em comum }\end{array}$ & $\begin{array}{l}\text { General Partnership, Limited Liability } \\
\text { Partnership (LLP) }\end{array}$ \\
\hline
\end{tabular}

\section{Tabela 2.2 - Possíveis equivalências operacionais}

\subsection{Estrutura de atos constitutivos}

\subsubsection{Documentos constitutivos nos EUA}

Nos EUA, as corporations normalmente precisam ter articles of incorporation e bylaws.

Os articles of incorporation contêm as seguintes informações (varia de estado a estado) (Steingold, 2001):

- O nome da sociedade,

- Seu objeto,

- O nome do "initial agent for the service process" (também chamado de registered agent ou resident agent). Esta é a pessoa autorizada a receber notificações e citações oficiais e de ações civis,

- O número de ações autorizadas,

- Os nomes e endereços dos incorporadores.

Os bylaws são mais detalhados e contêm:

- Os direitos e poderes dos acionistas, conselheiros e diretores da sociedade,

- A data e local da assembléia geral ordinária e outros detalhes sobre esta assembléia, 
- Disposições sobre assembléias extraordinárias,

- Definições a respeito do número de conselheiros, como são eleitos, como são remunerados, e seus títulos.

O corpus ing-br contém só um exemplar de Articles of Incorporation, documento dc1_us. Não há um exemplo de bylaws com tradução, mas alguns documentos no corpus se referem a bylaws.

Nos EUA, as Limited Liability Companies normalmente precisam ter articles of organization e um operating agreement. Os articles of organization contêm as seguintes informações (varia de estado a estado) (Steingold, 2001):

- O nome da sociedade,

- Seu objeto,

- O nome do "initial agent for the service process",

- O tipo de administração: pelos quotistas ou por um gerente,

- Sede,

- Duração.

O operating agreement só é necessário se a LLC tiver mais de um sócio. A sua função é semelhante àquela dos bylaws de uma corporation. Geralmente inclui disposições sobre as seguintes questões:

- As contribuições de todos os quotistas à empresa,

- Como a participação de cada quotista é calculada,

- O tipo de administração, se não especificado nos articles of organization,

- Votação em assembléias,

- Distribuição de lucros e perdas,

- Maneira de declarar renda à receita federal,

- Transferência de participação, novos quotistas, contrato de compra e venda de quotas. 


\subsubsection{Documentos constitutivos na Grä-Bretanha}

$\mathrm{Na}$ Grã-Bretanha, sociedades precisam de dois documentos, o memorandum of association e os articles of association. O memorandum of association contém:

- O nome da sociedade,

- Sua sede registrada,

- Seu objeto,

- As limitações de responsabilidade,

- O capital.

Os articles of association contêm as seguintes informações:

- Mais detalhes sobre o capital, transferência, etc.

- Quanto capital a sociedade pode conseguir via empréstimos,

- Assembléias, procedimentos, votações, procuradores,

- Poderes dos conselheiros, administração,

- Dividendos, notificações, dissolução, etc.

A figura 2.14 compara os documentos norte-americanos com os da Grã-Bretanha.

Observe que os Articles of Incorporation, Memoranda of Association e Articles of Organization contêm informações análogas. Da mesma maneira, os Bylaws, Articles of Association e Operating Agreements contêm informações análogas. 


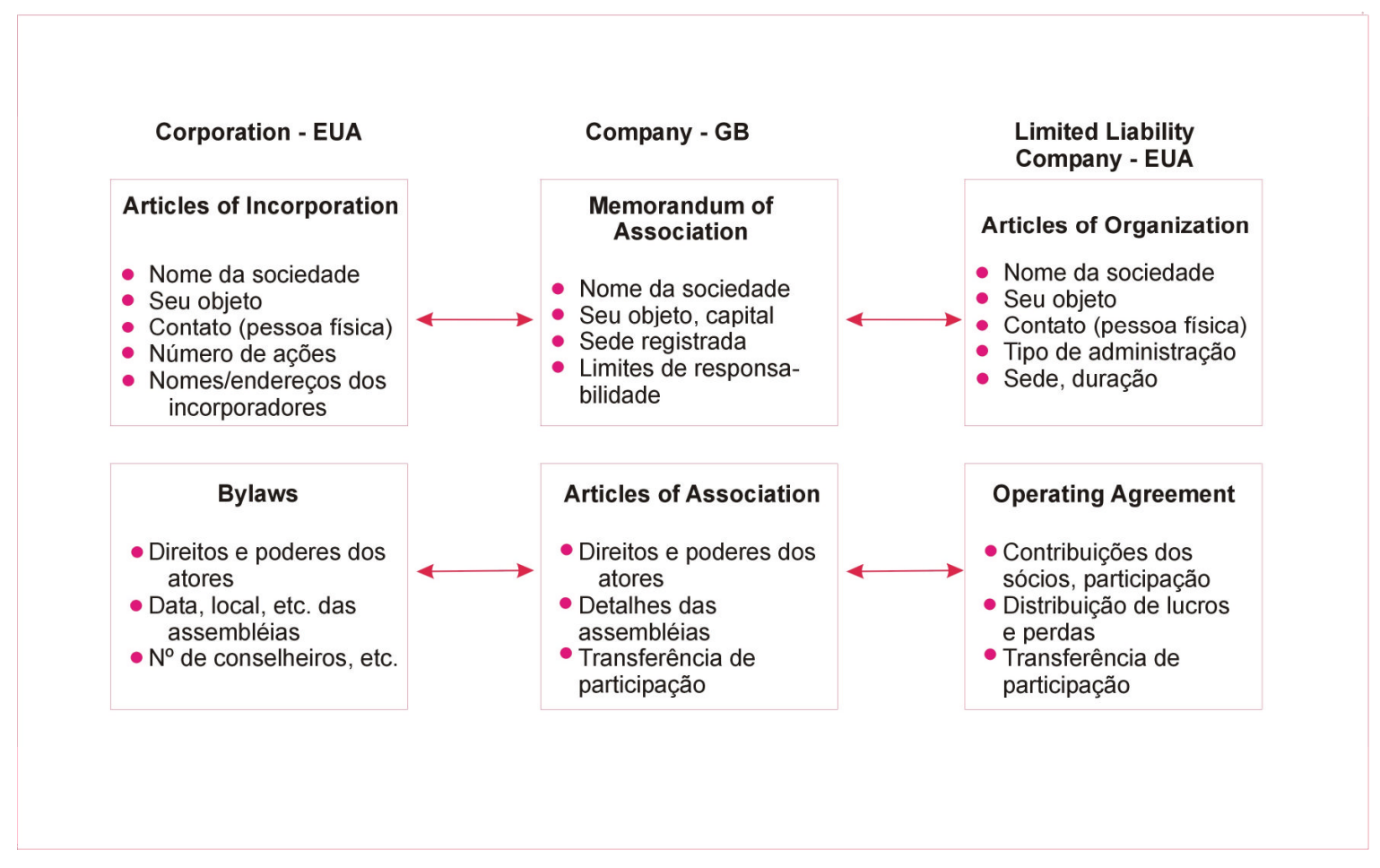

Figura 2.14 - Documentos constitutivos nos EUA e na GB

\subsubsection{Documentos constitutivos no Brasil}

O ato constitutivo no Brasil chama-se contrato social ou estatuto social, de acordo com o tipo de empresa. O contrato social é um contrato entre os sócios, enquanto um estatuto social define uma sociedade. Os acionistas aderem a este estatuto ao adquirirem participações na sociedade. O contrato social consiste em:

- As qualificações dos sócios,

- A denominação, objeto, sede e prazo da sociedade,

- O capital da sociedade e a quota e contribuição de cada sócio,

- As pessoas naturais incumbidas da administração, seus poderes e atribuições,

- A participação de cada sócio nos lucros e perdas,

- Se os sócios respondem, ou não, subsidiariamente pelas obrigações sociais.

(Fiuza, 2006, art. 997; Fazzio, 2004, p. 172) 
O estatuto social inclui, além das cláusulas citadas acima para o contrato social, definições a respeito do conselho de administração, os diretores, das assembléias gerais, tipos de ações, etc.

\subsubsection{Correspondências e possíveis equivalências operacionais e funcionais}

Ao procurar uma equivalência operacional para o contrato ou estatuto social, podemos ver que o conteúdo do contrato ou estatuto social corresponde ao conteúdo dos dois documentos constitutivos nos EUA (ou na GB) considerados juntamente. As figuras 2.15 a 2.17 abaixo mostram as equivalências operacionais parciais para os principais tipos de sociedade nos três países.

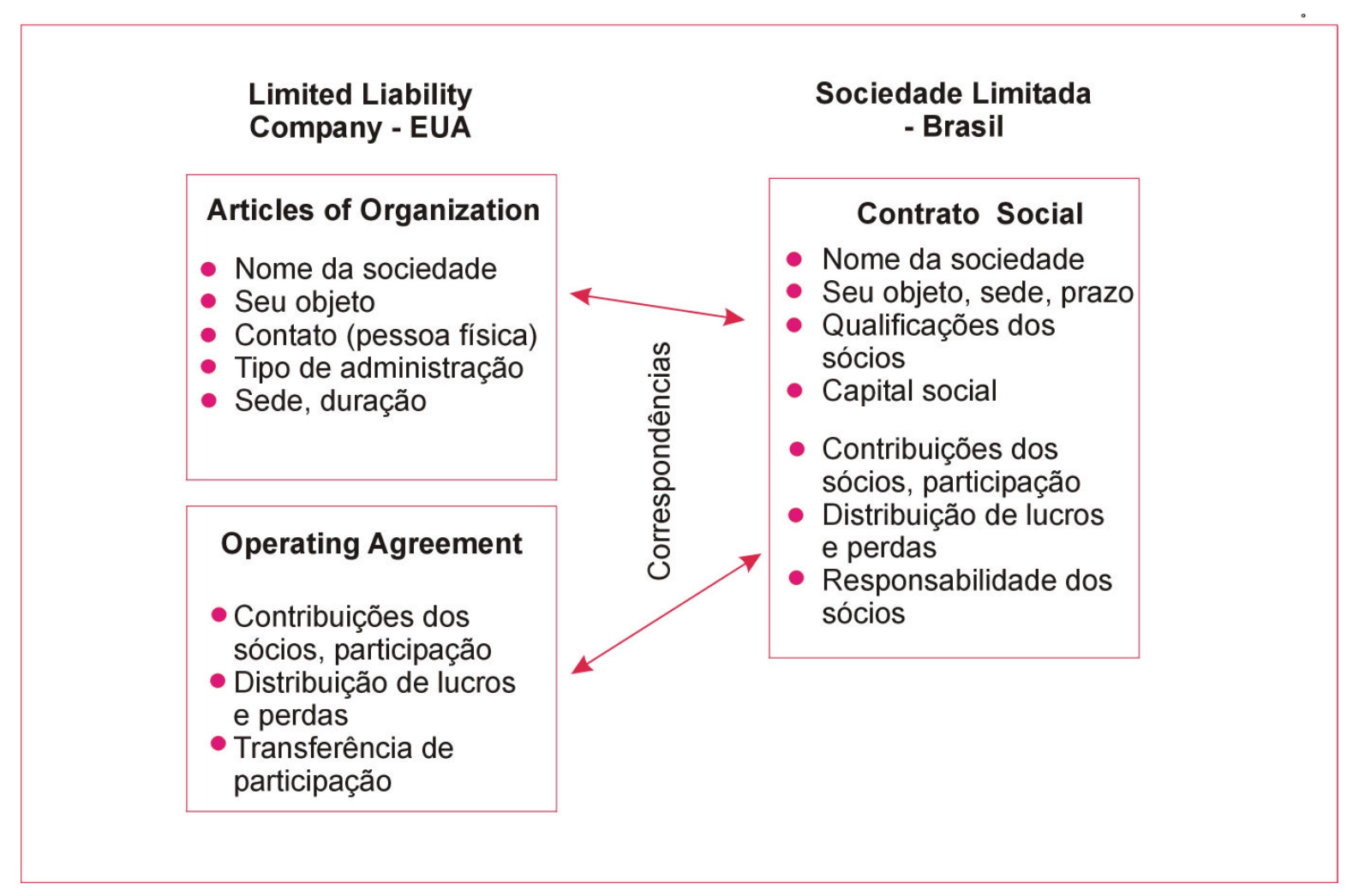

Figura 2.15 - Documentos constitutivos da Limited Liability Company/Sociedade Limitada 
Corporation - EUA

Articles of Incorporation

- Nome da sociedade

- Seu objeto

- Contato (pessoa física)

- Número de ações

- Nomes/endereços dos incorporadores

\section{Bylaws}

- Direitos e poderes dos atores

- Data, local, etc. das assembléias

- $\mathrm{N}^{\circ}$ de conselheiros, etc.

\section{Estatuto Social}

- Nome da sociedade

- Seu objeto

- Contato (pessoa física)

- Número de ações

- Nomes/endereços dos incorporadores

- Direitos e poderes dos atores

- Data, local, etc. das assembléias

- $\mathrm{N}^{\circ}$ de conselheiros, etc.

Figura 2.16 - Documentos constitutivos da Corporation/Sociedade Anônima

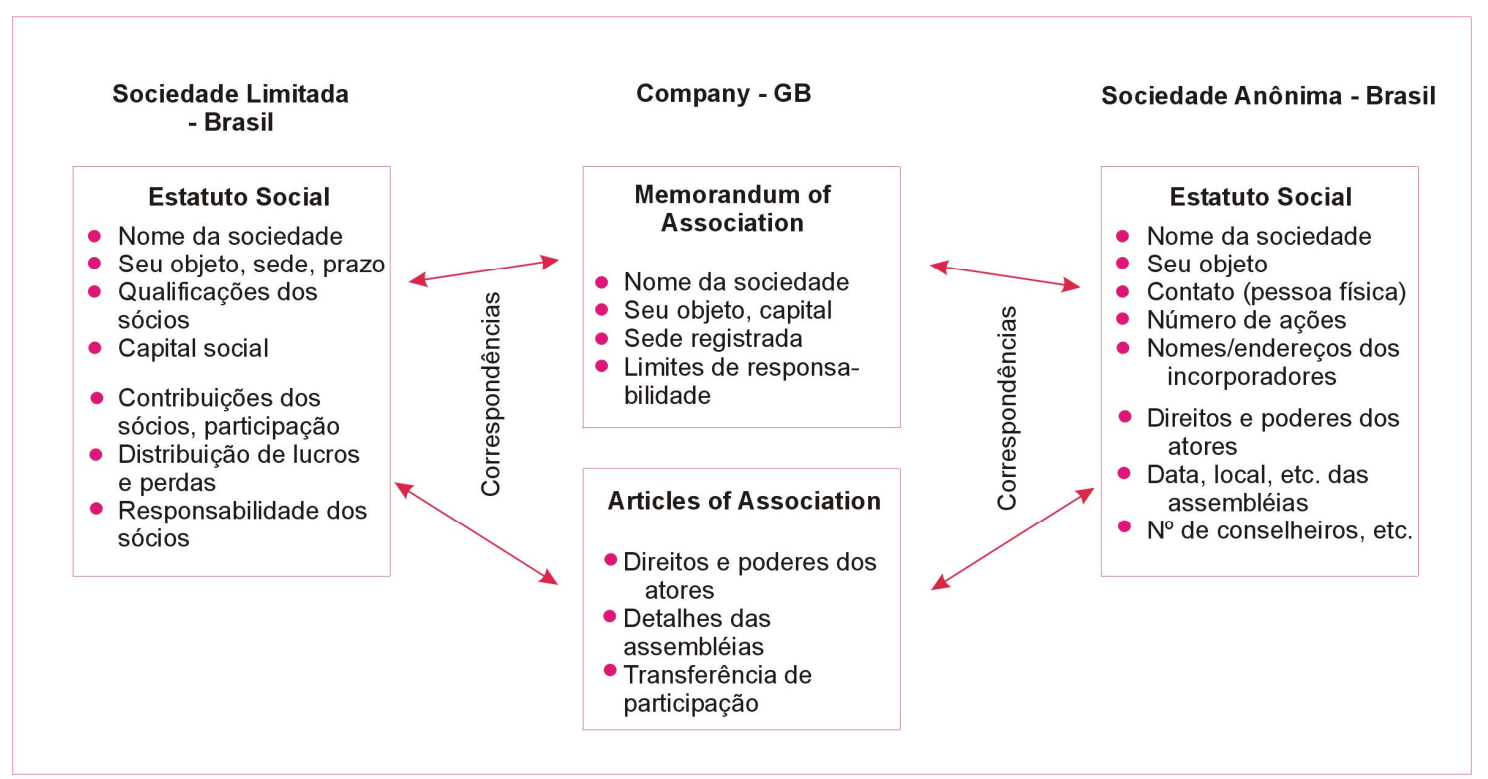

Figura 2.17 - Documentos constitutivos da Company/Sociedade Anônima/Sociedade Limitada 
Uma equivalência funcional (em que a função do documento é descrita) pode ser uma opção nessa situação em que não há correspondência operacional. Os dois documentos nos sistemas britânico/norte-americano poderiam ser traduzidos como "instrumento de constituição" e "acordo operacional". No sentido contrário, o contrato social e estatuto social poderiam ser chamados de "incorporation and operating document" ou "constituting and operating document" ou até "articles of incorporation and operation". Estas correspondências funcionais (na qual a tradução é uma descrição da função do termo original) estão mostradas nas figuras 2.18 e 2.19 .

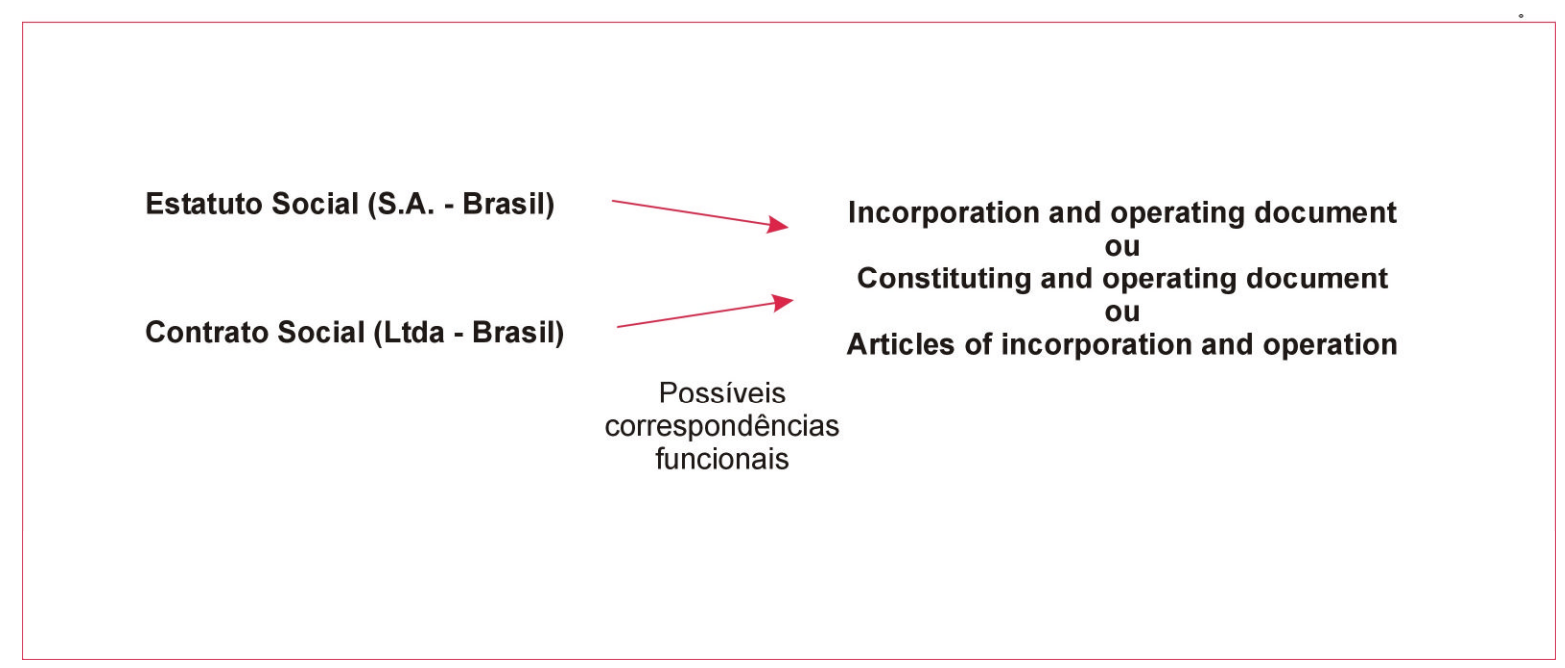

Figura 2.18 - Possíveis correspondências para estatuto e contrato social 


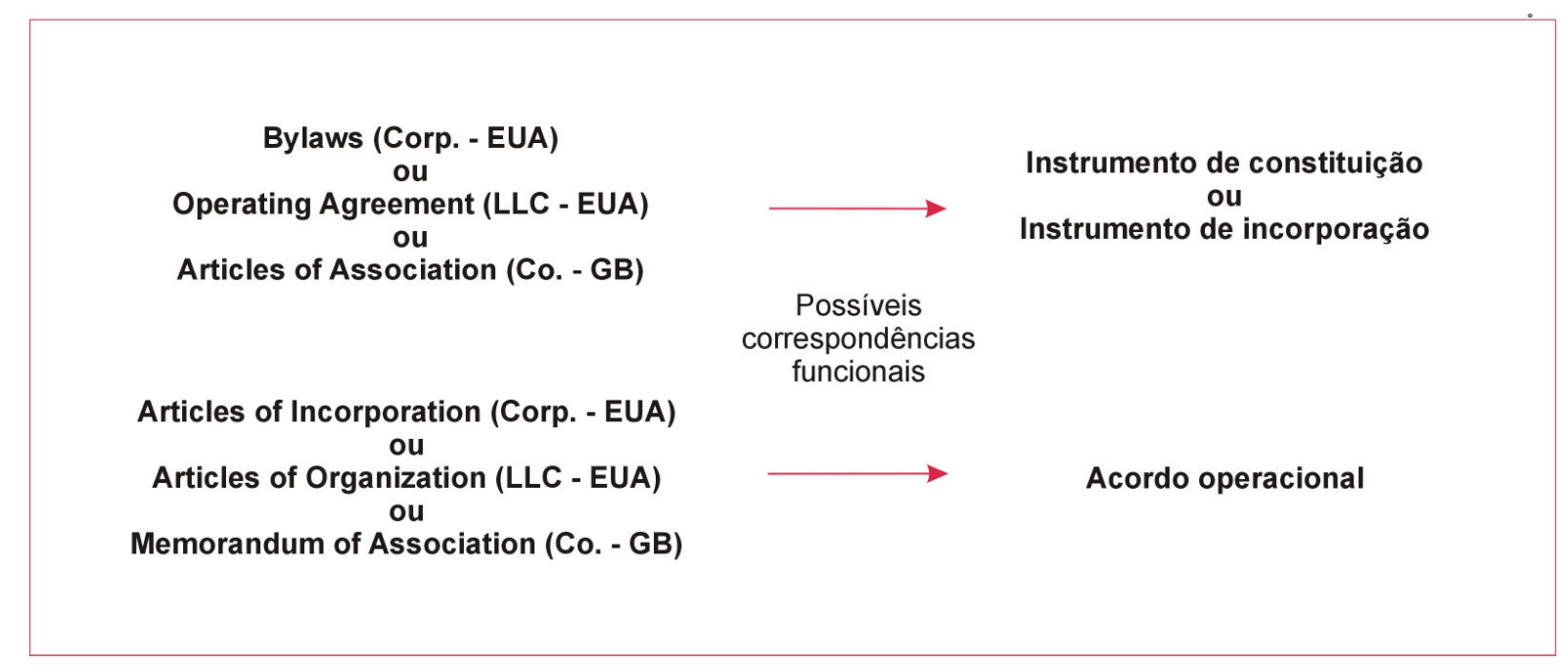

Figura 2.19 - Possíveis correspondências para documentos constitutivos em inglês

\subsection{Estrutura de contratos}

Esta seção apresenta a estrutura básica de contratos nos EUA, Grã-Bretanha e Brasil, e comenta algumas de suas características.

\subsubsection{A estrutura de contratos nos EUA e na Grä-Bretanha}

Livros sobre a elaboração de contratos, direcionados a advogados nos EUA e na GrãBretanha, como Adams (2001) e Child (1992), descrevem o formato padrão de contratos nos países com sistemas jurídicos derivados daquele da Grã-Bretanha. Este formato padrão consiste em uma combinação dos seguintes elementos (nem todos estão sempre presentes):

- title,

- introductory clause,

- definitions,

- recitals,

- body,

- concluding clause, ou testimonium clause,

- signature blocks,

- attachments. 
O documento abaixo (Figura 2.20) é uma amostra de um agreement no formato tradicional, com arcaísmos. Foi encontrado em um livro de modelos de contratos publicado nos EUA.

2 Date:

3 This indemnification agreement is made and entered on [date] by and between [first party], First Party, and [second party], Second Party.

4 WHEREAS The undersigned parties have agreed to resolve certain disputes which have arisen between them; and

5 WHEREAS, each party wishes the other to indemnify and hold the first party harmless from any and all costs and expenses which have arisen or may arise as a result of their prior relationship;

6 NOW THEREFORE, in consideration of the premises set forth herein and intending to be legally bound, the parties hereto agree as follows:

7 [first party] and affiliates hereby jointly and severally agree to indemnify and hold harmless [second party] and any affiliate of his/hers from every liability, claim, action, cause of action, judgment, loss, expense, or cost whatsoever (including but not limited to reasonable attorney's fees and court costs) arising from or in any way related to or resulting from:

8 (A) Any and all business relationships entered into between the Parties from the beginning of time to the date of these presents; and

9 (B) Any materially inaccurate representation made by either Party pursuant to their recent agreement; and

10 (C) [List any other items parties want to be indemnified from]. 
11 IN WITNESS WHEREOF the undersigned have hereunto set their hands this day of 19

12 First Party

13 Second Party

(Roberson, p. 435, 1994)

Figura 2.20 - Indemnification Agreement

Nesse exemplo, o primeiro parágrafo contém o title. Os parágrafos 2 e 3 contêm o introductory clause (com definições). Os parágrafos 4 e 5 contêm os recitals, cada parágrafo iniciado pelo ubíquo WHEREAS. O body do contrato começa com o também ubíquo NOW THEREFORE e continua até o fim do décimo parágrafo. O parágrafo 11 contém o concluding clause e os parágrafos 12 e 13 fariam parte dos signature blocks no contrato assinado.

Este formato com whereas e now therefore é considerado antiquado por alguns autores, e os livros sobre estilo recomendam não utilizá-los. Por exemplo, Adams escreve:

"In the majority of contracts, the recitals are independent clauses beginning with WHEREAS and linked by semicolons; recitals are, after all, commonly referred to as "whereas" clauses. This meaning of "whereas" is archaic, and in drafting recitals you should dispense with WHEREAS, along with the accompanying semicolons. ...Tradition requires that when the preceding recitals start with WHEREAS, the lead-in should begin NOW, THEREFORE. Once you rid yourself of WHEREAS, there is no reason to retain NOW, THEREFORE." (Adams, p. 13, 2001)

E Garner (1995) declara: 
"In the sense "given the fact that," whereas is the archetypal legalism-it was formerly every lawyer's idea of how to begin a recital in a contract. The more modern drafting style is to use a heading such as Recitals or Background, followed by short declarative sentences, as opposed to the sometimes unceasing stream of independent clauses linked by semicolons and whereases." (Garner, 1995, p. 929)

Outro arcaísmo é o termo IN WITNESS WHEREOF no concluding clause. Segundo Garner

\begin{abstract}
"[the] testimonium clause, in a sworn legal document, is the attestation clause that traditionally begins with the phrase In witness whereof, which commonly concludes legal instruments and pleadings. Among the traditional forms are the following: "In witness whereof I have subscribed my name this _ day of 19 _ / "Witness my signature this _ day of 19 _ / "In witness whereof we hereto set our hands and seals."" (Garner, 1995, p. 875)
\end{abstract}

Segundo Adams (2001, p.64) "the musty IN WITNESS WHEREOF can, like WITNESSETH, be dispensed with, on the grounds that contracts rarely need to be witnessed".

Há várias cláusulas consagradas em contratos, inclusive estas sobre Governing Law e Entire Agreement:

Governing Law. This Agreement shall be construed in accordance with the laws of England and Wales and shall be subject to the exclusive jurisdiction of the English courts. (301 Legal Forms, 2002)

Entire Agreement. This Agreement contains the entire Agreement between the Parties and supersedes all prior arrangements and understandings whether written 
or oral with respect to the subject matter hereof and may not be varied except in writing signed by both the Parties hereto. (301 Legal Forms, 2002)

Quando há cláusulas análogas nos dois universos jurídicos, a tradução tende a se basear em equivalências discursivas (este conceito é explicado no terceiro capítulo).

\subsubsection{A estrutura de contratos no Brasil}

O formato de contratos no Brasil é um pouco diferente do formato apresentado acima, devido às diferenças entre os pressupostos do sistema civil e o sistema baseado em jurisprudência. $\mathrm{O}$ formato padrão consiste em uma combinação dos seguintes elementos (nem todos são sempre presentes):

- título,

- qualificações das partes,

- corpo,

- cláusula de conclusão,

- assinaturas,

- anexos.

O documento abaixo (Figura 2.21) é uma amostra de um contrato no formato padrão. Foi encontrado em um livro de modelos de contratos publicado no Brasil.

2 Por este instrumento particular de comodato, de um lado (nome, qualificação e endereço), titular do CPF n. ${ }^{\circ}$..., na condição de comodante e (nome, qualificação e endereço), inscrito no CPF sob o n. ${ }^{o}$.........., na condição de comodatário, tem entre si, justo e contratado o seguinte:

3 Cláusula 1. - Do Objeto - O comodante é proprietário do seguinte móvel. (descrever com todas as características, estado de conservação, número, marca, cor, etc). 
4 Cláusula 2. ${ }^{\mathrm{a}}$ - Da Duração - Por este instrumento e na melhor forma de direito, cede o comodante ao comodatário o mencionado móvel, pelo prazo de ....... para a seguinte finalidade...... (o prazo poderá ser indeterminado, havendo nesse caso necessidade de notificação para constituição em mora e retomada do bem).

5 Cláusula $3 .^{\mathrm{a}}$ - Demais Disposições - O presente instrumento é realizado pela forma dos artigos 579 e seguintes do Código Civil.

61 - As partes se obrigam a cumprir o presente por si, seus herdeiros e sucessores.

72 - Indicam o foro da comarca de para dirimirem eventuais litígios sobre o presente instrumento

83 - E assim, por estarem justos e acordados, firmam o presente em duas (2) vias de igual teor e forma na presença de duas testemunhas a tudo presente, para que surta seus efeitos de direito.

9 (local e data)

10 (assinatura dos comodantes)

11 (assinatura dos comodatários)

12 (assinatura de duas testemunhas, com indicação de nome, endereço e número de documento)

(Parizatto, 2006, p. 138-9)

Figura 2.21 - Instrumento Particular de Comodato de Móvel

Nesse exemplo, o primeiro parágrafo contém o título. O segundo parágrafo contém as qualificações das partes. O corpo começa com o parágrafo 3, com as cláusulas consagradas "do objeto" e "da duração". O parágrafo 7 é o último do corpo, e contém o texto padrão sobre eleição de foro (semelhante à cláusula acima "governing law"). O parágrafo 8 é a cláusula de conclusão, seguida pela data e as assinaturas das partes e testemunhas.

As diferenças mais evidentes entre contratos em inglês e em português são:

1. as qualificações completas das partes (e parciais das testemunhas) nos contratos brasileiros e a quase ausência de informações equivalentes em contratos em inglês; 
2. a necessidade de testemunhas no Brasil em quase todo documento jurídico, e a necessidade de notarização e/ou registro de um número muito maior de documentos neste país;

3. a presença de recitals com whereas em contratos em inglês e sua quase ausência em documentos em português;

4. a presença de uma seção de definições no início de contratos em inglês e sua ausência em documentos em português. 


\section{Fundamentação teórica}

\subsection{Teorias gerais de tradução}

\subsubsection{Palavra por palavra e sentido por sentido}

O debate sobre tradução ao longo dos séculos tem sido entre tradução "palavra por palavra" (literal) e tradução "sentido por sentido" (livre). Em 46 AC, Cícero defendeu seu método de traduzir o sentido e não a forma dos discursos de oradores gregos. Na época, era comum traduzir discursos do grego para o latim literalmente palavra por palavra, para a tradução em latim servir como referência para a leitura do grego.

S. Jerônimo cita Cícero quando defende sua tradução do velho testamento contra críticos. Foi entendido pelos tradutores seguintes que S. Jerônimo também sustentava que uma tradução livre seria melhor. A idéia era de que uma tradução palavra por palavra resultava em estruturas agramaticais, que ofuscavam o sentido do original.

Martinho Lutero também argumentava em favor da tradução livre, para defender a sua interpretação da Bíblia. Um conceito importante que ele defendeu foi a necessidade de pensar no leitor, e o efeito do texto no leitor. Ele entendeu a importância de traduzir de uma maneira que seria entendida pelo leitor, priorizando o leitor e sua língua e não o idioma/cultura do texto original.

Dryden, no século 17, escreveu muito sobre tradução e traduzia poesia do grego. Ele falava de três modos de tradução (em vez de só dois):

1) metaphrase (metáfrase) - palavra por palavra,

2) paraphrase (paráfrase) - sentido por sentido,

3) imitation (imitação)- adaptação do texto à época e língua de chegada.

Dryden preferia a paráfrase, mas também argumentou a favor dos outros dois modos em momentos diferentes. 


\title{
3.1.2 Schleiermacher
}

Em 1813, Friedrich Schleiermacher escreveu um tratado muito influenciador sobre a tradução, Über die verschiedenen Methoden des Übersetzens (Sobre os diferentes métodos de traduzir). Ele distingue dois tipos de tradutores, aqueles que traduzem textos comerciais e aqueles que traduzem textos acadêmicos e artísticos. Infelizmente, ele despreza a tradução comercial (necessária, mas sem interesse) e o restante do trabalho é sobre tradução literária. Em vez de abordar os métodos literais e livres (que ele menciona), ele enfatiza a aproximação do leitor ao autor original.

\begin{abstract}
"But what paths are open to the true translator, one who would bring those two utterly unconnected people together, the source-language author and the targetlanguage reader - and would aid the latter, without banishing him from the sphere of the target language, in attaining as accurate and thorough an understanding and enjoyment of the former? I believe there are only two. The translator either (1) disturbs the writer as little as possible and moves the reader in his direction, or (2) disturbs the reader as little as possible and moves the writer in his direction. " (Schleiermacher, 1813/2002, p. 229)
\end{abstract}

Schleiermacher preferia o primeiro método, aproximar o leitor ao escritor.

\begin{abstract}
"Given two people as far apart as the author of the original and the potential reader of the translation - people who don't even speak each other's language! - is it really advisable to bring them into a relationship as intimate as that between the author and the source-language reader?" (Schleiermacher, 1813/2002, p. 228)
\end{abstract}

Em outras palavras, ele propôs que o tradutor não deve escrever como se fosse o autor original escrevendo no idioma de chegada. Ao contrário, o leitor deve ter a mesma impressão, ao ler o texto traduzido em seu próprio idioma, que teria se tivesse lido a obra no idioma 
original (mas como estrangeiro fluente no idioma de partida). Schleiermacher promove a estrangeirização em vez da domesticação. A cultura e o idioma de partida são valorizados. Ele cria que o tradutor deveria treinar o receptor a aceitar traduções com o gosto forte do estrangeiro. Esse ponto de vista é o contrário daquele de Martinho Lutero. Esses temas são retomados por Venuti (1995) como foreignization e domestication.

\subsection{O Modelo de Vinay e Darbelnet}

Vinay e Darbelnet $(1958,1977)$ foram os primeiros a criarem categorias para descrever as alterações feitas ao texto original para produzir o texto traduzido. Eles perceberam que a tradução exige o conhecimento não somente de dois idiomas, mas também de duas culturas, duas histórias. Um conceito mencionado no estudo deles é que "o tradutor traduz para fazer o leitor compreender o texto". (Vinay e Darbelnet, 1977, p. 24, tradução minha) Eles, porém, também se concentram na estilística comparada, que pode ser estudada através do estudo de traduções entre dois idiomas. Eles consideram três aspectos de línguas: o léxico, o ordenamento das palavras e a mensagem. O modelo de Vinay e Darbelnet foi desenvolvido para servir para qualquer tipo de tradução, inclusive poesia, literatura, textos técnicos, etc.

Uma das dificuldades neste estudo e em qualquer estudo sobre a tradução é a definição da unidade de estudo. Os autores declaram que apesar de sua aparente conveniência, a palavra não é uma unidade satisfatória. Um problema com a utilização da palavra como a unidade de estudo é que esse método enfatizaria o significante e não o significado (entendendo-se aqui os conceitos de Saussure $(1972,1986))$. Eles declaram:

Il lui faut donc une unité que ne soit pas exclusivement formelle, puisqu'il ne travaille sur la forme qu'aux deux extrémités de son raisonnement. Dans ces conditions, l'unité à dégager est l'unité de pensée, conformément au principe que le traducteur doit traduire des idées et des sentiments et non des mots. (Vinay e Darbelnet, 1977, p. 37)

E portanto, o trabalho define a unidade de estudo como 
"[les] unités lexicologiques dans lesquelles les éléments du lexique concourent à l'expression d'un seul élément de pensée. On pourrait encore dire que l'unité de traduction est le plus petit segment de l'énoncé dont la cohésion des signes est telle qu'ils ne doivent pas être traduits séparément." (Vinay e Darbelnet, 1977, p. 37)

Os autores dão exemplos em seguida, mas esta definição de unidade de estudo é difícil de tratar de maneira científica, pois dificilmente duas pessoas dividiriam um texto nas mesmas unidades segundo essas regras.

Vinay e Darbelnet separaram seus procedimentos (procédés) de tradução em duas categorias - tradução direta e tradução oblíqua. Eles apresentam os procedimentos do mais fácil ao mais difícil de implementar. Um resumo é apresentado na tabela 3.1, com os nomes originais em francês na coluna à direita.

\begin{tabular}{|l|l|l|}
\hline tradução direta & empréstimo & [emprunt] \\
\cline { 2 - 3 } & decalque & [calque] \\
\cline { 2 - 3 } & tradução literal & [traduction littérale] \\
\hline tradução obliqua & transposição & [transposition] \\
\cline { 2 - 3 } & modulação & [modulation] \\
\cline { 2 - 3 } & equivalência & [équivalence] \\
\cline { 2 - 3 } & adaptação & [adaptation] \\
\hline
\end{tabular}

Tabela 3.1 - Resumo dos procedimentos

Empréstimo ocorre quando a palavra da língua de partida é utilizada na tradução. Para Vinay \& Darbelnet, esse é o procedimento mais fácil. Decalque é um tipo especial de empréstimo quando as palavras são traduzidas literalmente, mas a estrutura da expressão não é modificada. 
Tradução literal (ou palavra por palavra) ocorre quando há uma correspondência uma a uma entre as palavras no texto original e na tradução. Um exemplo é "Where are you?" traduzido para "Onde está você?" Segundo os autores, a tradução literal deve ser descartada se a mensagem, quando traduzida literalmente,

a) dá um outro significado, ou

b) não faz sentido, ou

c) é impossível estruturalmente, ou

d) não corresponde à experiência metalingüística do idioma de chegada, ou

e) corresponde a uma expressão no idioma de chegada, mas não dentro do mesmo registro.

Transposição ocorre quando uma palavra de uma classe é substituída por uma palavra de outra classe. Um exemplo seria "após sua volta" traduzido como "after he returns", em que um substantivo "volta" é traduzido com um verbo "return". Modulação é uma variação na forma da mensagem, obtida através de uma alteração no ponto de vista. Um exemplo é o negativo do contrário: "é fácil demonstrar" para "it is not difficult to show".

Equivalência inclui onomatopéias ("bow-wow" traduzido por "au-au"), provérbios, clichês e expressões idiomáticas.

O último procedimento, adaptação, é o limite extremo segundo os autores. Utiliza-se adaptação quando uma nova situação precisa ser encontrada, pois a situação original não existe na cultura de chegada. Um exemplo seria a substituição de um esporte típico em um país por um outro, típico no outro. 


\subsection{Modificações do modelo de Vinay e Darbelnet}

\subsubsection{Vázquez-Ayora}

Em 1977, Váquez-Ayora escreveu um estudo semelhante àquele de Vinay e Darbelnet (e baseado nele), mas para os idiomas inglês e espanhol-Introducción a la Traductología. Como Vinay e Darbelnet, Váquez-Ayora também descarta a palavra como uma possível unidade de estudo, e fala da unidade de tradução e a unidade de pensamento. Ele baseia seu estudo na unidade lexicológica, que define como "a menor combinação de palavras que contribuem à expressão de um único fragmento de uma mensagem e cujo grau de interdependência é tal que não podem ser traduzidos isoladamente dentro do contexto da mensagem como um todo". Em seguida, ele repete a lista de tipos de unidades já fornecida por Vinay e Darbelnet.

Váquez-Ayora fornece exemplos de todos os procedimentos de Vinay e Darbelnet para o par inglês/espanhol e acrescenta mais alguns procedimentos. O novo procedimento amplificação (Vázquez-Ayora, 1977, p. 334-349) ocorre quando mais palavras são utilizadas na tradução do que no original, por motivos relacionados à gramática e à estilística do idioma de chegada. Um exemplo do texto (alterado para o português) é

We are dancing to the accordion traduzido para

Dançamos ao som do acordeão.

Nesse exemplo, "to" se torna "ao som de", um maior número de palavras. O procedimento contrário seria omissão, que Vinay e Darbelnet também deixaram de incluir em seu modelo (Vázquez-Ayora, 1977, p. 358-373).

Vázquez-Ayora também introduziu o procedimento explicitação (Vázquez-Ayora, 1977, p. 349-358). A diferença entre amplificação e explicitação é que explicitação é utilizada devido à semântica e não à gramática. Um exemplo do texto (alterado para o português) é

To help resolve the basic question of delegation 
traduzido para

Para resolver os problemas básicos da delegação de poderes.

\subsubsection{Barbosa}

O estudo de Barbosa (2004) não aborda a questão da unidade de estudo. Ela resenha os estudos anteriores e propõe um reajuste nos procedimentos de Vinay e Darbelnet e de Vázquez-Ayora. Barbosa introduz uma nova categoria—tradução palavra por palavra-que é mais restrita do que a tradução literal, pois o número de palavras e suas classes não podem mudar do original para a tradução. Ela fala brevemente das equivalências de Newmarkfuncional, descritiva e cultural-mas só como subcategorias da equivalência de Vinay e Darbelnet. Baseado nas definições dos procedimentos equivalência e modulação desses autores, seria possível defender a inserção das equivalências de Newmark como subcategorias de modulação e não de equivalência.

Barbosa também dá nomes novos para os procedimentos explicitação e amplificação de Vázquez-Ayora. Explicitação se torna explicação (de sentido) e amplificação se torna explicitação (de gramática). A categoria empréstimo de Vázquez-Ayora é rebatizada de transferência, com a criação de várias subcategorias (veja a seção 3.4 para mais detalhes).

No final do estudo, Barbosa aborda o ordenamento dos procedimentos de tradução. O primeiro ordenamento é por freqüência de uso. $\mathrm{O}$ segundo é pela convergência ou divergência lingüística e extralingüística entre a língua de partida e a língua de chegada. Nesse esquema, os procedimentos são distribuídos por quatro eixos: 1) convergência do sistema lingüístico, da realidade extralingüística e do estilo; 2) divergência do sistema lingüístico; 3) divergência do estilo e 4) divergência da realidade extralingüística (Barbosa, 2004, p. 91-93). Sua categorização dos procedimentos ao longo desses eixos é apresentada na tabela 3.2. 


\begin{tabular}{|l|l|}
\hline Eixo & Procedimentos \\
\hline $\begin{array}{l}\text { convergência do sistema lingüístico, da } \\
\text { realidade extra-lingüística e do estilo }\end{array}$ & $\begin{array}{l}\text { tradução palavra-por-palavra } \\
\text { tradução literal }\end{array}$ \\
\hline divergência do sistema lingüístico & $\begin{array}{l}\text { transposição } \\
\text { modulação } \\
\text { equivalência }\end{array}$ \\
\hline divergência do estilo & $\begin{array}{l}\text { omissão vs. explicitação } \\
\text { compensação } \\
\text { reconstrução } \\
\text { melhorias }\end{array}$ \\
\hline divergência da realidade extralingüística & $\begin{array}{l}\text { transferência } \\
\text { transferência com explicação } \\
\text { decalque } \\
\text { explicação } \\
\text { adaptação }\end{array}$ \\
\hline
\end{tabular}

Tabela 3.2 - Categorização dos procedimentos por Barbosa (2004)

\subsubsection{Aubert}

Enquanto os modelos anteriores são fundamentalmente didáticos—ou seja, propõe-se, explícita ou implicitamente, como "técnicas" ou "procedimentos" para auxiliar o tradutor aprendiz a tomar suas decisões tradutórias, o modelo de Aubert (1984, 1998, 2005a) é sobretudo descritivo. Por isso, os procedimentos são aqui chamados de modalidades, para enfatizar essa alteração de ponto de vista, de procedimento didático para análise descritiva. $\mathrm{O}$ modelo modifica as categorias desenvolvidas por outros estudiosos, mas também altera a unidade de estudo. Para poder analisar os textos de maneira consistente e criar estatísticas, o modelo descritivo utiliza a palavra como a unidade de estudo. Aubert (1998) descreve o método em detalhes, com muitos exemplos. A tabela 3.3 fornece um resumo das modalidades. 


\begin{tabular}{|c|c|c|c|}
\hline & omissão & \multicolumn{2}{|c|}{$\begin{array}{l}\text { Um dado segmento textual do texto original } e \text { a informação nele } \\
\text { contida são omitidos na tradução. }\end{array}$} \\
\hline \multirow[t]{5}{*}{$\begin{array}{l}\text { tradução } \\
\text { direta }\end{array}$} & transcrição & \multicolumn{2}{|c|}{$\begin{array}{l}\text { A transcrição de segmentos de texto que pertencem a ambas as } \\
\text { línguas envolvidas ou não pertencem nem à língua de chegada } \\
\text { nem à língua de partida, e sim a uma terceira língua. }\end{array}$} \\
\hline & empréstimo & \multicolumn{2}{|c|}{$\begin{array}{l}\text { Um segmento textual do texto original é reproduzido na tradução } \\
\text { com ou sem marcadores específicos de empréstimo (aspas, itálico, } \\
\text { negrito, etc.). }\end{array}$} \\
\hline & decalque & \multicolumn{2}{|c|}{$\begin{array}{l}\text { Uma palavra ou expressão é emprestada da língua de partida, mas } \\
\text { (i) foi submetida a certas adaptações gráficas e/ou morfológicas } \\
\text { para conformar-se às convenções da língua de chegada, e (ii) não } \\
\text { se encontra registrada nos principais dicionários recentes da língua } \\
\text { de chegada. }\end{array}$} \\
\hline & \multirow[t]{2}{*}{$\begin{array}{l}\text { tradução } \\
\text { literal }\end{array}$} & $\begin{array}{l}\text { tradução } \\
\text { palavra-por- } \\
\text { palavra }\end{array}$ & $\begin{array}{l}\text { Comparando-se os segmentos textuais original e } \\
\text { tradução, se observa: (i) o mesmo número de } \\
\text { palavras, (ii) na mesma ordem sintática, (iii) } \\
\text { empregando as mesmas categorias gramaticais e } \\
\text { (iv) contendo as opções lexicais que podem ser } \\
\text { tidas por sendo sinônimos interlingüísticos. }\end{array}$ \\
\hline & & Transposição & $\begin{array}{l}\text { Este ocorre sempre que pelo menos um dos três } \\
\text { primeiros critérios que definem a tradução literal } \\
\text { deixa de ser satisfeito. }\end{array}$ \\
\hline \multirow[t]{3}{*}{$\begin{array}{l}\text { tradução } \\
\text { indireta }\end{array}$} & explicitação & \multicolumn{2}{|c|}{$\begin{array}{l}\text { Informações implícitas contidas no texto original se tornam } \\
\text { explícitas na tradução. }\end{array}$} \\
\hline & implicitação & \multicolumn{2}{|c|}{$\begin{array}{l}\text { Informações explícitas contidas no texto original tornam-se } \\
\text { referências implícitas. }\end{array}$} \\
\hline & modulação & \multicolumn{2}{|c|}{$\begin{array}{l}\text { Um determinado segmento textual é traduzido de modo a impor } \\
\text { um deslocamento perceptível na estrutura semântica de superfície, } \\
\text { embora retenha o mesmo efeito geral de sentido no contexto }\end{array}$} \\
\hline
\end{tabular}




\begin{tabular}{|l|l|l|}
\hline & específico. \\
\cline { 2 - 3 } & Adaptação & $\begin{array}{l}\text { Assimilação cultural; a solução tradutória adotada para o segmento } \\
\text { textual dado estabelece uma equivalência parcial de sentido. }\end{array}$ \\
\cline { 2 - 3 } $\begin{array}{l}\text { Tradução } \\
\text { inter- } \\
\text { semiótica }\end{array}$ & Figuras, ilustrações, logomarcas, selos, brasões e similares \\
\cline { 2 - 3 } & Erro & Erros, mas não soluções tradutórias percebidas como inadequadas. \\
\cline { 2 - 3 } Correção & Correção de erros factuais e/ou lingüísticos, inadequações e gafes \\
\cline { 2 - 3 } & $\begin{array}{l}\text { Acréscimo } \\
\text { Qualquer segmento textual incluído no texto alvo pelo tradutor por } \\
\text { sua própria conta }\end{array}$ \\
\hline
\end{tabular}

Tabela 3.3 - Resumo das modalidades de Aubert (2005a)

Estas modalidades servirão de base para as modalidades definidas para este estudo. Um resumo da evolução dos procedimentos e modalidades será fornecido na próxima seção.

\subsection{Modelo utilizado neste estudo}

\subsubsection{Contexto sociocultural}

Para muitos, tradução jurídica é tradução juramentada. Para outros, há tradução jurídica juramentada e não juramentada. Porém, a questão é muito mais complexa do que estes dois extremos. Há muitos motivos para traduzir um documento jurídico e todos eles são válidos. Inspirada no trabalho de Holz-Mänttäri sobre Translational Action como descrito em Munday (2001, p. 77-78), criei categorias para descrever as possíveis motivações dos atores envolvidos, ou seja, o motivo por que a tradução foi encomendada, por que o documento original foi escrito, e os leitores esperados do texto original e da tradução. O modelo de Translational Action proposto por Holz-Mänttäri conceitualiza o processo de tradução como orientado a um fim específico e contempla a interação entre os atores envolvidos e transferência intercultural. 
[It] is not about translating words, sentences or texts but is in every case about guiding the intended co-operation over cultural barriers enabling functionally oriented communication. (Holz-Mänttäri, 1984, p. 7-8, tradução de Munday)

Neste modelo, tradução é um processo comunicativo que inclui os seguintes atores:

o iniciador: a pessoa física ou jurídica que precisa da tradução,

o cliente: o indivíduo que entra em contato com o tradutor,

o autor do texto original: o indivíduo que escreveu o texto original,

o tradutor: o indivíduo que produz a tradução,

o usuário da tradução: o indivíduo que utiliza a tradução de alguma maneira,

o receptor da tradução: o indivíduo que lê a tradução, ou a quem é apresentada.

Cada ator tem suas metas e suas contribuições. O objetivo é ter uma tradução que pode ser utilizada para comunicação, em termos funcionais, com o receptor. Segundo este modelo, a forma e o gênero da tradução precisam convir às necessidades da cultura do receptor. No contexto desse estudo, isso seria o universo jurídico e lingüístico do país de chegada.

Numa tentativa de descrever as situações tradutórias dos documentos coletados para os corpora, simplifiquei o modelo para:

o cliente: o indivíduo ou empresa que entra em contato com o tradutor,

o autor: o indivíduo que escreveu o texto original, e a empresa que representa (não diferencio aqui entre o advogado e a empresa representada por ele),

a outra parte: a outra pessoa jurídica ou física citada no contrato ou procuração, que às vezes é também um receptor da tradução,

terceiros: pessoas receptores do original ou da tradução,

o tradutor: o indivíduo que produz a tradução,

o juíz: um dos receptores da tradução juramentada ou certificada, pode ser qualquer órgão oficial. 
A primeira situação tradutória (e suas duas variações) é apresentada na figura 3.1.

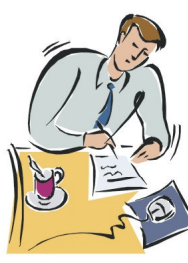

$1^{\text {a }}$ parte - autor

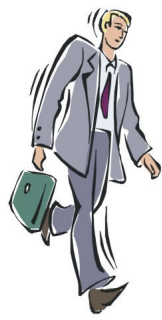

$2^{\mathrm{a}}$ parte
Cliente
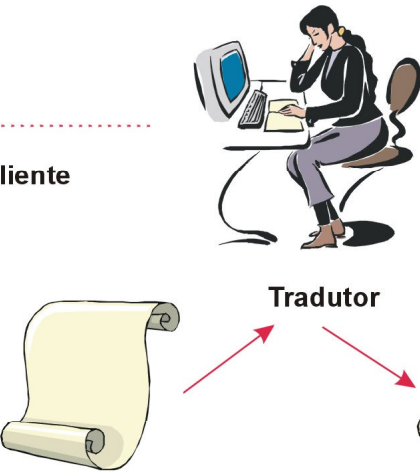

Original

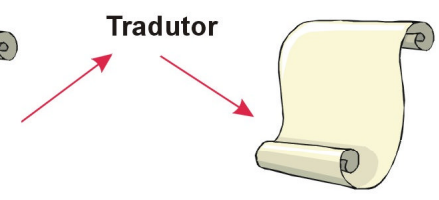

Tradução

Situação A1 - original é assinado e é válido; tradução ajuda a compreensão da $2^{\mathrm{a}}$ parte e de terceiros

Situação A2 - original é modelo, mas tradução é assinada e se torna a única versão válida.

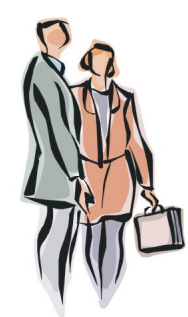

Terceiros Receptores

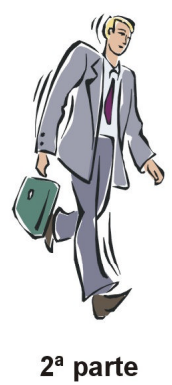

Figure 3.1 - Situações tradutórias A1 e A2

Na situação A1, o original é assinado e é válido. A tradução ajuda a compreensão da $2^{\mathrm{a}}$ parte e de terceiros. Um exemplo comum dessa situação é quando uma empresa assina um contrato com outra empresa no mesmo país e precisa mandar este contrato para a matriz em outro país, ou para órgãos internacionais por algum motivo. A tradução serve só para fins informacionais.

Na situação A2, o original só serve de modelo e a tradução se torna um original no país de chagada. A tradução é assinada pelas partes e se torna a única versão válida legalmente. Um exemplo da situação A2 é quando uma empresa brasileira (autor) quer fazer uma parceria com uma empresa estrangeira ( $2^{\mathrm{a}}$ parte) e manda traduzir o contrato para a língua da segunda parte para facilitar comunicação durante as negociações. Quando a empresa estrangeira não tem uma presença no Brasil, e portanto não tem representante jurídico aqui, normalmente quer assinar o contrato no próprio idioma e não em português. Nesse caso, o documento seria mais 
uma adaptação à cultura do país de chegada do que em outras situações, pois a tradução seria mais desligada do original.

Uma segunda situação tradutória (e suas duas variações) é apresentada na figura 3.2.
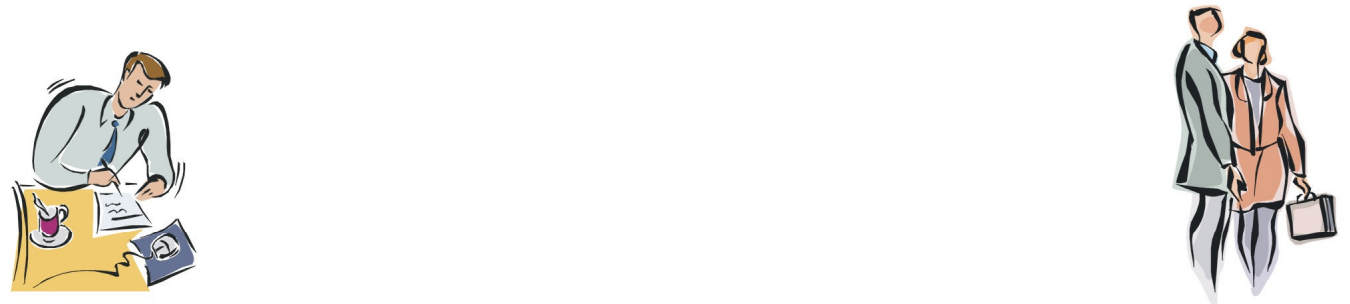

$1^{\mathrm{a}}$ parte - autor
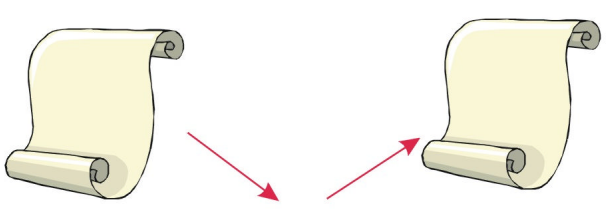

Terceiros

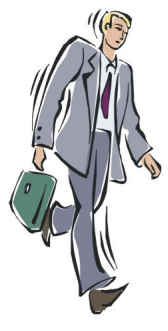

$2^{\mathrm{a}}$ parte

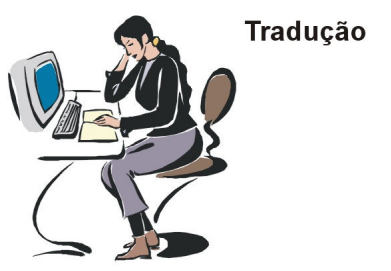

Tradutor

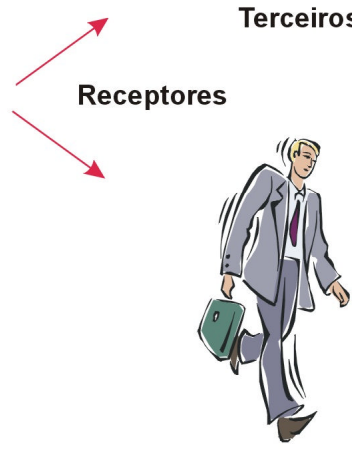

$2^{\mathrm{a}}$ parte

Situação B1 - original é assinado e é válido;

tradução ajuda a compreensão da $2^{\mathrm{a}}$ parte e de terceiros.

Situação B2 - original é modelo, mas tradução é assinada e se torna a única versão válida. (RARO)

Figure 3.2 - Situações tradutórias B1 e B2

Na situação B1, é a segunda parte ao contrato que contrata o tradutor, ou até um terceiro. Nesse caso, o original é assinado e é válido, e a tradução ajuda a compreensão da $2^{\mathrm{a}}$ parte e de terceiros. Em um exemplo típico da situação B1, uma empresa brasileira como Eletropaulo ou Petrobras faz uma licitação com a participação de empresas estrangeiras. A empresa que faz a proposta contrata um tradutor para traduzir o contrato (e normalmente os outros documentos técnicos relacionados à licitação) para entender os termos. Porém, é o original que é assinado. 
Uma situação rara é a B2, em que a tradução é assinada em vez do original. Nesse caso, um exemplo possível é que o autor do documento original representa a empresa com menos poder na relação entre as partes. A 2a parte traduz o contrato e o modifica, e é a tradução que é assinada.

Uma terceira situação tradutória (e suas duas variações) é apresentada na figura 3.3.

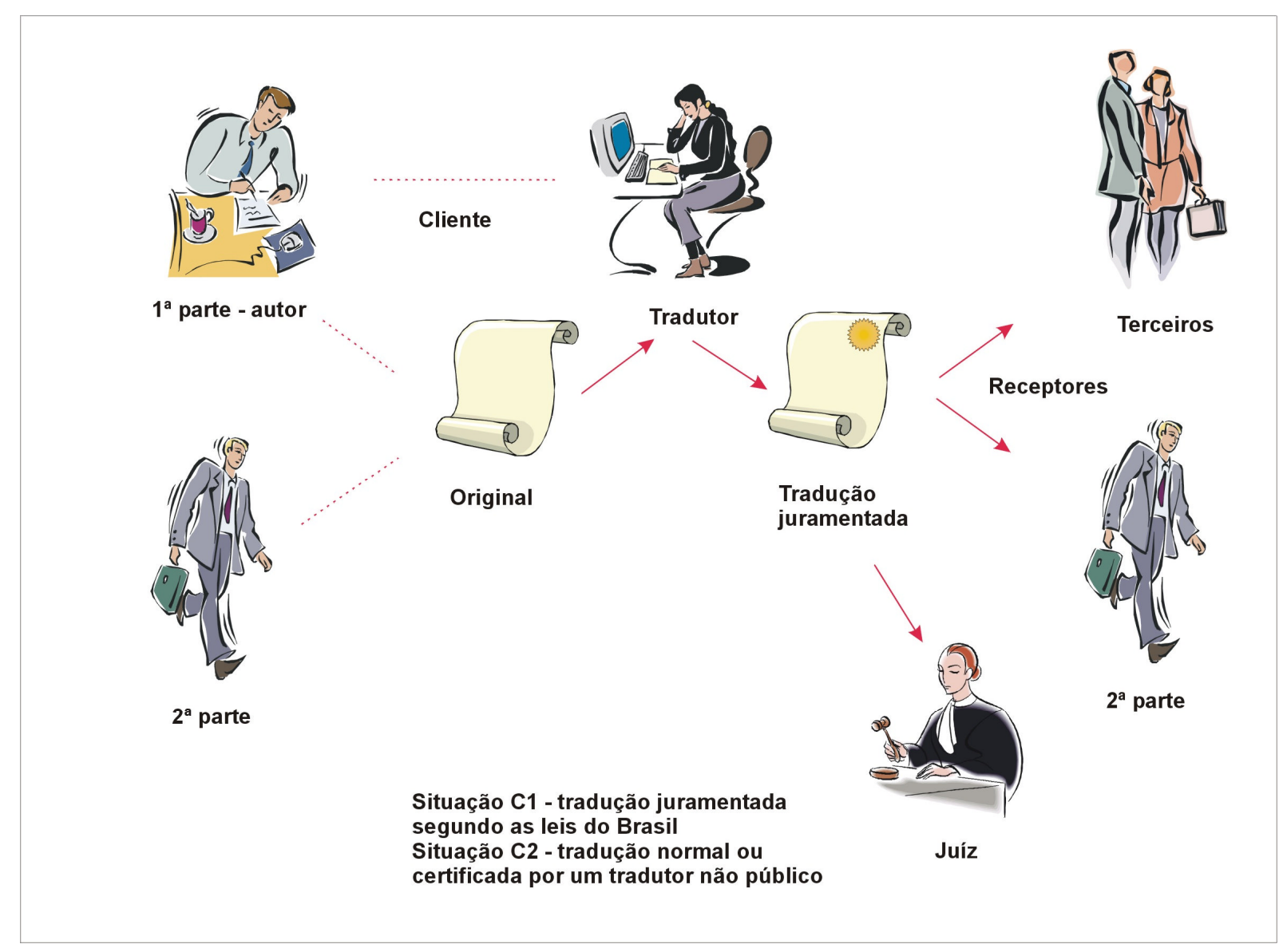

Figure 3.3 - Situações tradutórias C1 e C2

Nessa situação tradutória, o documento é traduzido por um tradutor público quando o objetivo é poder utilizá-lo em juízo ou para fins oficiais - especialmente no Brasil, mas nem sempre. As autoridades de países estrangeiros no Brasil (consulados/embaixadas) freqüentemente exigem traduções juramentadas. Nos EUA e no Reino Unido, não existe o conceito de 
tradutor público. Normalmente, quando a tradução é para fins oficiais, o tradutor é obrigado a anexar um certificado declarando que a tradução é correta e que ele/ela é um tradutor profissional. Como se define "profissional" é aberto à interpretação. Há várias certificações e diplomas (de sociedades de tradutores e de faculdades) que normalmente são aceitos. Não há nenhuma regra geral.

Uma quarta situação tradutória (e suas três variações) é apresentada na figura 3.4.

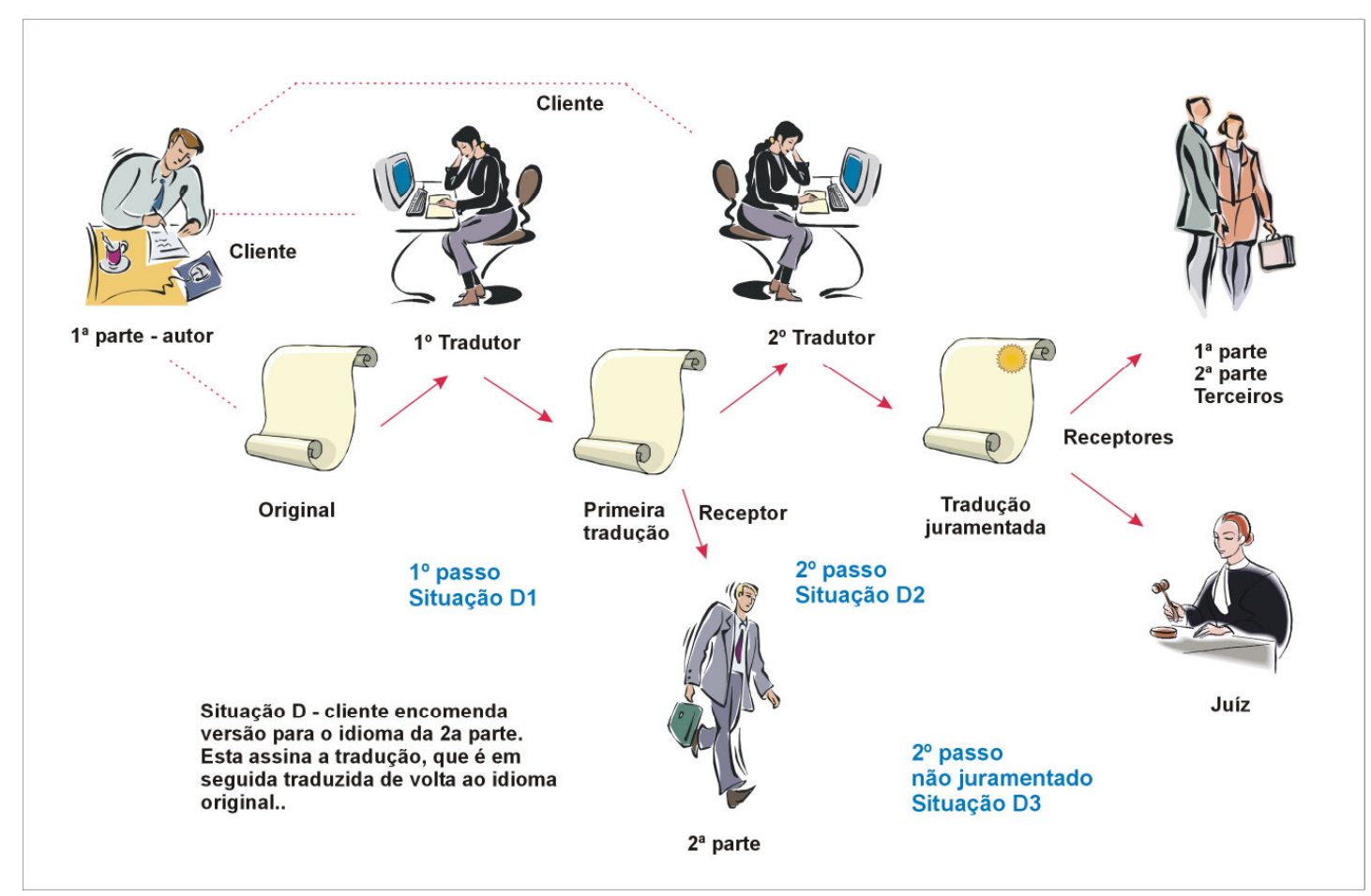

Figure 3.4 - Situações tradutórias D1, D2 e D3

Nesta situação, um documento é traduzido para o idioma da $2^{a}$ parte (situação D1), é assinado por esta e traduzido de volta para o idioma original por um tradutor oficial (situação D2) ou por um tradutor não oficial (situação D2). Esta situação (D) é mais comum com o original escrito em português. Infelizmente, os corpora não contêm nenhum caso de documentos representando o primeiro e segundo passo do mesmo documento original. Geralmente, por motivos desconhecidos, os tradutores dos dois passos são diferentes. É possível que a primeira tradução seja feita por alguém dentro da empresa que posteriormente contrata o tradutor 
público para o segundo passo. Às vezes, é difícil distinguir entre as situações tradutórias $\mathrm{C}$ e o segundo passo da situação tradutória D (D2 e D3). Quando o "original" é escrito em um inglês pouco idiomático ou mesmo contendo incorreções, é mais fácil identificar a tradução como pertencente à situação tradutória D2 ou D3.

\subsubsection{Definição da unidade de estudo}

Vimos nas seções anteriores as definições da unidade de estudo utilizadas por outros estudiosos trabalhando com procedimentos/modalidades. Neste estudo, também adotei a unidade lexicográfica utilizada por Vázquez-Ayora, mas definida através de explicitação de sentido e através da repetição natural dentro do corpus e dentro das línguas em questão.

Em geral, um termo consiste em um substantivo modificado por um ou mais adjetivos, ou consiste em um verbo modificado por um ou mais advérbios. Estes vão além de simples colocações. Como decidir quais modificadores incluir? Somente aqueles que façam com que o conceito representado se torne mais específico (ou mais geral) do que o substantivo com os modificadores mais próximos. Cada modificador explicita mais o significado pretendido. Alguns exemplos podem clarificar esta definição. O termo sociedade limitada brasileira é uma única unidade de estudo porque sociedade limitada é mais específico do que sociedade e porque sociedade limitada brasileira é mais específico ainda. Um outro exemplo é o termo sociedade por quotas de responsabilidade limitada. Este termo é uma única unidade porque responsabilidade limitada está modificando quotas (são as quotas que são de responsabilidade limitada) e a sociedade é dividida por este tipo de quota. O termo inteiro é mais específico do que só sociedade por quotas, explicita mais o significado (apesar de sociedade por quotas provavelmente ser entendido pela maioria de leitores devido ao contexto, sem a inclusão do modificador "de responsabilidade limitada").

Um outro exemplo é o "contrato social consolidado". Nesse contexto, não é possível tomar "contrato social" como a unidade de estudo porque o contrato social é um documento e o contrato social consolidado é outro documento, resultante de uma modificação do primeiro. 
O nome de órgãos do governo, como a "Secretaria de Segurança Pública" seria um outro exemplo de uma unidade lexicográfica. Muitos desses termos são dicionarizados em dicionários específicos à área jurídica ou até em dicionários de abrangência maior.

As linguagens jurídicas norte-americana e brasileira contêm muitos binômios idiomáticos e não idiomáticos. Os que aparecem freqüentemente no corpus (e em textos jurídicos em geral) foram considerados uma única unidade de estudo, pois normalmente são traduzidos como se o fossem. Exemplos incluem "true and lawful" e "by and between". Em português, há exemplos como "residente e domiciliado" e "nomeio e constituo".

O agrupamento de colocações depende de sua freqüência no corpus e na linguagem jurídica em geral. Muitas colocações são tão comuns que se tornam esperadas até nas traduções para o idioma em questão. No caso de colocações, o agrupamento foi feito (ou não) na hora da análise baseado nos exemplos encontrados nos corpora.

Há muitas frases feitas, especialmente frases arcaicas como "in witness whereof", "know all men by these presents" e em português "dou fé" e "na melhor forma de direito". São tomadas como uma única unidade de estudo devido à sua repetição sem modificação e por não terem um significado transparente para o leitor.

As unidades de estudo são marcadas nos exemplos com sublinhado, negrito ou itálico.

\subsubsection{Definição das modalidades de tradução}

Como este estudo é descritivo e não prescritivo, vou manter o nome "modalidades" para as categorias de análise segundo o raciocínio de Aubert (1984). Nesta seção, vou apresentar as modalidades que utilizei para descrever as soluções encontradas pelos tradutores jurídicos que contribuíram os documentos que constituem os corpora ing-br e br-ing. Os nomes das modalidades são baseados nas denominações de Aubert, com modificações (às vezes extensas) introduzidas no nível de subcategoria. 


\subsubsection{Tradução literal}

\section{Vinay \& Darbelnet}

Na figura 3.5 apresento um diagrama da evolução das categorias transposição e tradução literal originalmente definidas por Vinay \& Darbelnet (1958). As definições de Vinay \& Darbelnet são simples e incompletas quando comparadas com as modificações e detalhes introduzidos pelos modelos posteriores. Vinay \& Darbelnet definiram a transposição como o método em que a classe de uma das palavras na tradução é modificada (por exemplo, adjetivo para substantivo) sem modificar o significado da mensagem. A tradução literal seria aquela em que as classes das palavras não são modificadas.

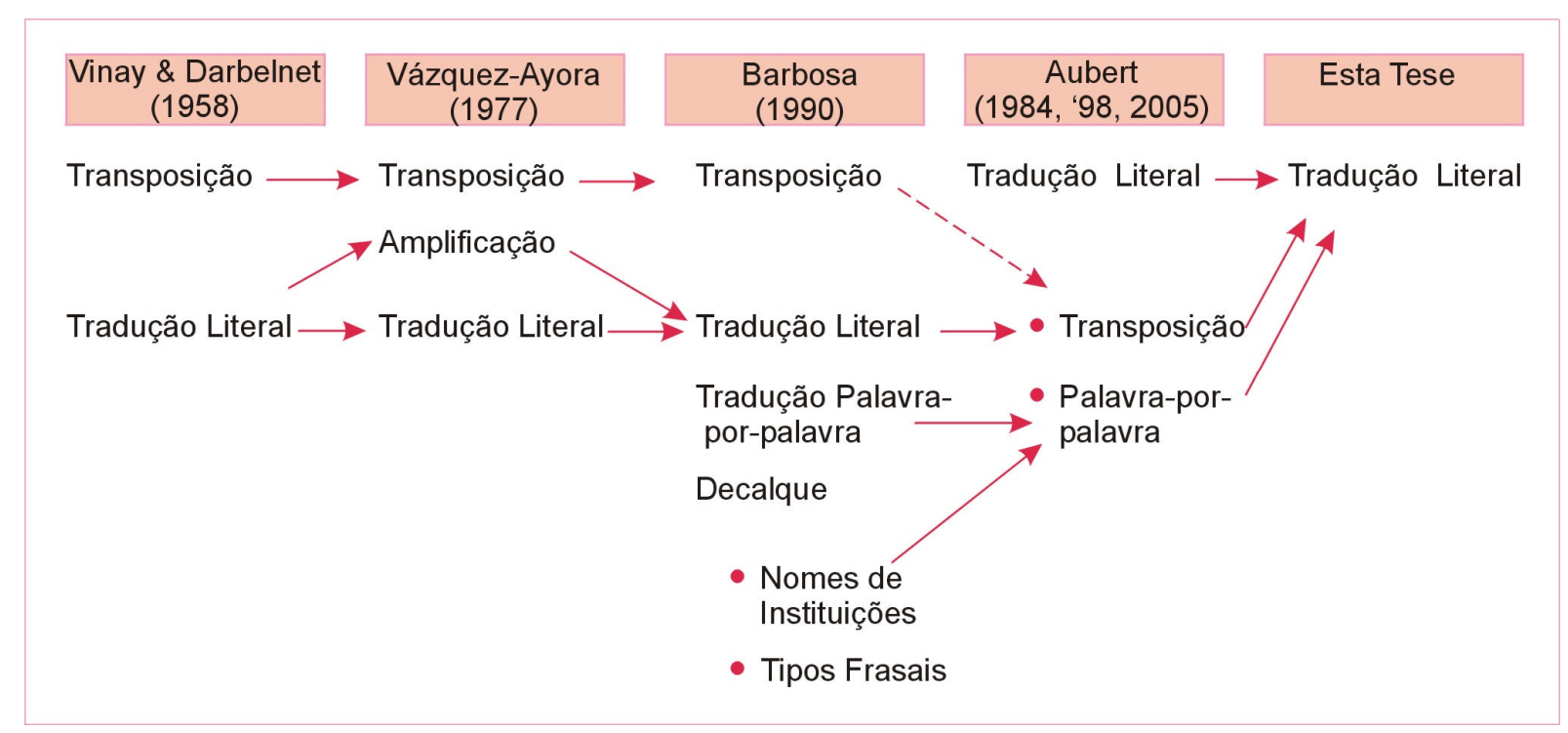

Figura 3.5 - Tradução literal

\section{Vázquez-Ayora}

O modelo de Vázquez-Ayora introduz o conceito de amplificação, no qual uma palavra no original se torna duas palavras na tradução. Um exemplo seria:

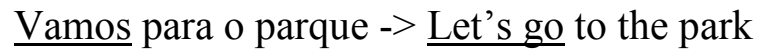


É interessante observar que não foi proposta uma categoria oposta, redução, para o caso contrário. Um exemplo semelhante é dado em Vinay e Darbelnet sob a categoria tradução literal, mas a categoria amplificação não é mencionada especificamente.

\section{Barbosa}

Barbosa define a categoria transposição igual a Vinay e Darbelnet, ou seja, como uma mudança de classe gramatical de uma ou mais palavras na tradução. Porém, ela introduz a categoria tradução palavra por palavra, que só se aplica quando não há mudança de classe e quando o número de palavras e sua ordem não mudam na tradução. Sua tradução literal permite a amplificação introduzida por Vázquez-Ayora (e a respectiva redução). Sua definição desse procedimento não é muita clara, mas parece incluir a definição de tradução literal de Vinay \& Darbelnet, subtraídos os casos de tradução palavra por palavra e tradução literal de nomes de instituições, que ela categoriza como um tipo de decalque.

\section{Aubert}

O modelo de Aubert considera (desde 2005) a tradução literal como uma categoria geral, com a tradução palavra por palavra e a transposição como subcategorias. Considero a proposta de Aubert mais apropriada para meu modelo porque a diferença entre estas duas subcategorias é extremamente dependente da estrutura da língua de chegada (e sua proximidade à língua de saída) e não provém de uma escolha do tradutor.

\section{Este estudo}

Normalmente, só a tradução literal palavra por palavra ou a tradução literal com transposição é correta na língua em questão, e não é uma escolha do tradutor. Como este estudo busca analisar as escolhas do tradutor, estas duas subcategorias serão classificadas como tradução literal 


\subsubsection{Modulação e Equivalência}

Vinay \& Darbelnet

Na figura 3.6 apresento um diagrama da evolução das categorias modulação e equivalência originalmente definidas por Vinay \& Darbelnet (1958). A modulação foi definida como uma variação na forma da mensagem devido a uma diferença de ponto de vista. Um exemplo seria é fácil mostrar -> não é difícil mostrar.

Eles definem equivalência de uma maneira restritiva, e concentram-se em exclamações e onomatopéias. Os exemplos dados são

$$
\begin{aligned}
& \text { meow -> miau } \\
& \text { Ouch! -> Ai! }
\end{aligned}
$$

Outros exemplos são de provérbios, clichês, e expressões idiomáticas. Um exemplo seria matar dois coelhos com uma cajadada só -> kill two birds with one stone.

Nenhum dos exemplos fornecidos lembra algo que apareceria em um texto jurídico. 


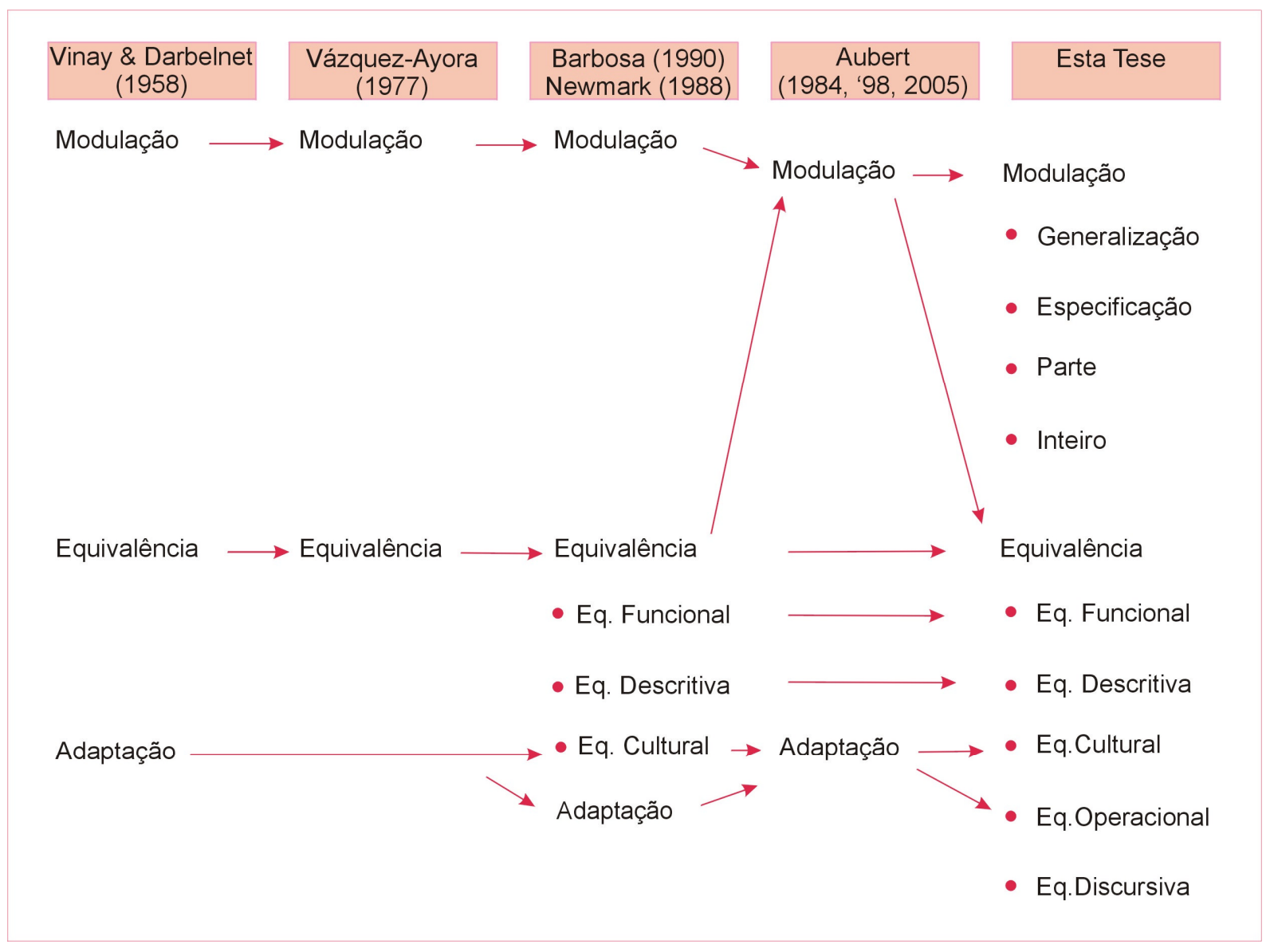

Figura 3.6 - Evolução das categorias modulação e equivalência

Barbosa, Newmark e Aubert

Vásquez-Ayora e Barbosa aceitam as definições de Vinay \& Darbelnet sem modificações, mas Barbosa também menciona os três tipos de equivalência definidos por Newmark (1988). Ela não entra em detalhes, mas os conceitos são particularmente interessantes para este estudo.

Aubert cria uma categoria chamada modulação que combina as categorias equivalência e modulação dos estudos anteriores, pois são semelhantes. Para os fins deste estudo, porém, concordo com Salkie (2001), quando declara "One could easily conclude that a concept [modulation] which covers so many different translation changes is too vague to be of any use." Juntando modulação e equivalência - sem criar subcategorias-ficamos com uma macrocategoria que seria pouco útil se uma porcentagem grande das soluções encontradas 
fosse classificada simplesmente como "modulação". Este trabalho mantém as duas categorias-modulação e equivalência-e cria subcategorias baseadas nos conceitos de Newmark (equivalência cultural, funcional e descritiva) e outras subcategorias baseadas em alguns conceitos de Vinay e Darbelnet.

\section{Newmark}

Segundo a definição de Newmark, a equivalência cultural ocorre quando uma palavra culturalmente marcada vem traduzida por um equivalente igualmente culturalmente marcado no idioma de chegada, às vezes com o qualificador do país. Alguns exemplos são:

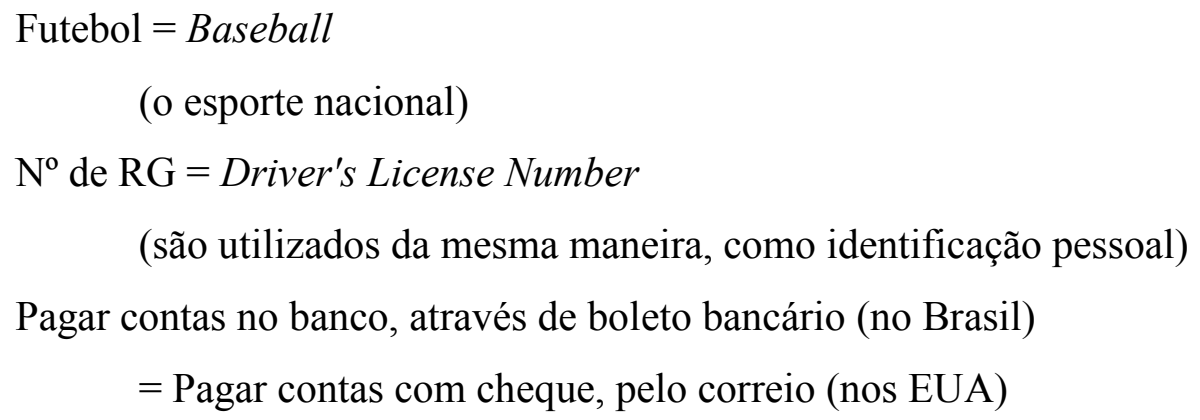

Newmark (1988, p. 83) julgava que o uso dessa equivalência na tradução seria limitada, pois não é exata. "...but they can be used in general texts, publicity and propaganda, as well as for brief explanation to readers who are ignorant of the relevant SL culture." Ele também declara que "the main purpose of the procedure is to support or supplement another translation procedure in a couplet". Essa subcategoria englobaria o que Vinay e Darbelnet chamavam de adaptação, em que a situação descrita no texto original é convertida em uma situação conhecida na cultura de chegada.

A equivalência funcional ocorre quando uma palavra não culturalmente marcada é utilizada para descrever a função de uma palavra culturalmente marcada. Alguns exemplos são:

vestibular $=($ Brazilian $)$ university entrance exam. 
Durable Power of Attorney $=$ Procuração com poderes gerais e subsistentes na incapacidade do outorgante

A tradução explica o conceito ou descreve o objeto através de suas funções. O objetivo é neutralizar o termo na língua de chegada. Segundo Newmark (1988, p. 83) a equivalência funcional ocupa o meio-termo, o universal, entre a cultura/língua de partida e a de chegada.

Ele também define a equivalência descritiva, em que o objeto é descrito de alguma maneira, por exemplo fisicamente. É difícil uma equivalência ser puramente descritiva, pois a função tende a ser inclusa também. Um exemplo seria

camundongo $=$ small rodent

Não se espera ver muitas equivalências descritivas na tradução de documentos jurídicos.

\section{Este estudo}

Além das equivalências cultural, descritiva e funcional de Newmark, a análise dos marcadores nos corpora deixou aparente a necessidade da criação de mais duas categorias de equivalência.

No universo desse estudo, ou seja, na área jurídica, há um tipo de equivalência que poderia ser chamada de equivalência operacional, pois é o uso ou a maneira de operar que cria a equivalência. $\mathrm{O}$ conceito, objeto ou entidade representado pelo termo utilizado na tradução funciona da mesma maneira (em um ou mais aspectos) que o conceito, objeto ou entidade representado pelo termo utilizado no original. Essa equivalência é referencial, ou seja, referese a um conceito ou objeto que existe fora do texto traduzido. Um exemplo de equivalência operacional seria a tradução do animal norte-americano skunk (mephitis mephitis), que não existe no Brasil, pelo gambá (gênero Didelphis), pois os dois emitem um líquido maucheiroso ao serem atacados. Outro exemplo seria a tradução de Sociedade Anônima pelo 
termo Corporation, pois os dois operam da mesma maneira, em termos da responsabilidade dos sócios, emissão de ações, etc.

A segunda subcategoria nova é a equivalência discursiva, que é a substituição de uma palavra ou fraseologia no texto original por uma outra no texto traduzido devido à sua função dentro do contexto do documento, e não em referência a um objeto ou conceito fora do documento. Dois exemplos disso são:

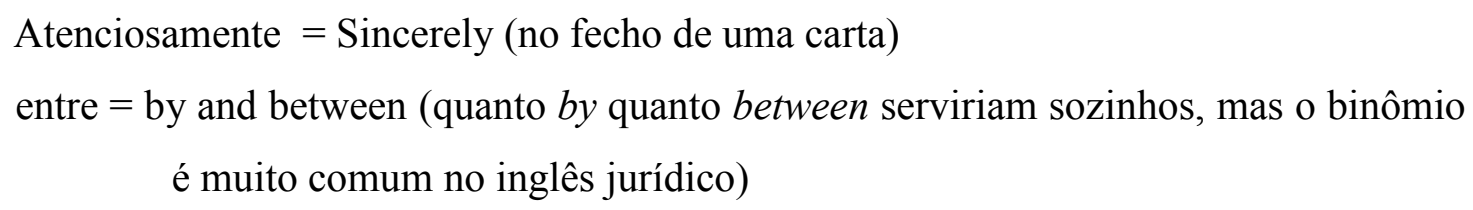

Também procurei subcategorias de modulação compatíveis com meus dados. Vinay e Darbelnet já falaram de subcategorias de modulação (Vinay e Darbelnet, 1977, p. 236-241). Estes são:

- o abstrato pelo concreto (ou o geral pelo particular)

- a causa pelo efeito

- o meio pelo resultado

- a substância pelo objeto

- a parte pelo todo

- uma parte por outra

- a inversão de sentido

- o negativo do contrário

- o ativo pelo passivo

- o espaço pelo tempo

- o intervalo pelo limite (em espaço ou em tempo)

- a alteração do símbolo 
No universo desse estudo, a substituição de uma parte pelo todo e seu contrário, e a substituição de uma categoria por sua subcategoria (o geral pelo particular) e seu contrário foram muito comuns, e mereceram subcategorias próprias. Estas são:

- a modulação através de especificação,

- a modulação através de generalização,

- a modulação através do todo substituído por uma parte,

- a modulação através da parte substituída pelo todo.

Um exemplo de especificação e generalização é quando um tipo de sociedade é substituído por uma categoria mais geral de sociedade ou pela própria palavra "sociedade", e vice versa. Um exemplo de uma parte substituída pelo todo é quando um tribunal é substituído por uma expressão que representa o sistema judicial como um todo. A diferença é que especificação e generalização são relacionadas a categorias, enquanto parte/todo são relacionados a coisas concretas, objetos ou entidades que têm partes definidas.

\subsubsection{Explicitação, omissão, implicitação e acréscimo}

Vinay \& Darbelnet não definiram nenhuma destas 4 categorias explicitamente. Explicitação, amplificação e omissão foram definidas por Vázquez-Ayora, com a categoria explicitação para os casos nos quais o tradutor esclarece o sentido de um termo no texto original, amplificação quando o tradutor utiliza um maior número de palavras do que no original, e omissão quando o tradutor elimina uma palavra presente no original. Barbosa define explicação como explicitação de sentido e explicitação como amplificação por motivos

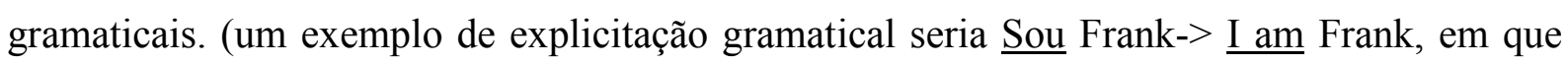
uma palavra vem traduzida por duas). No modelo de Aubert, a explicitação gramatical se torna transposição de número de palavras. Outra inovação de Aubert foi a criação da categoria implicitação, que difere da categoria omissão porque supõe que o sentido omitido é subentendido pelo leitor do texto traduzido. Outra modalidade de Aubert, acréscimo, que é o contrário de omissão, se mostrou necessária durante a análise dos corpora. Essa modalidade representa um acréscimo de sentidos não presentes nem implícitos no texto original. 


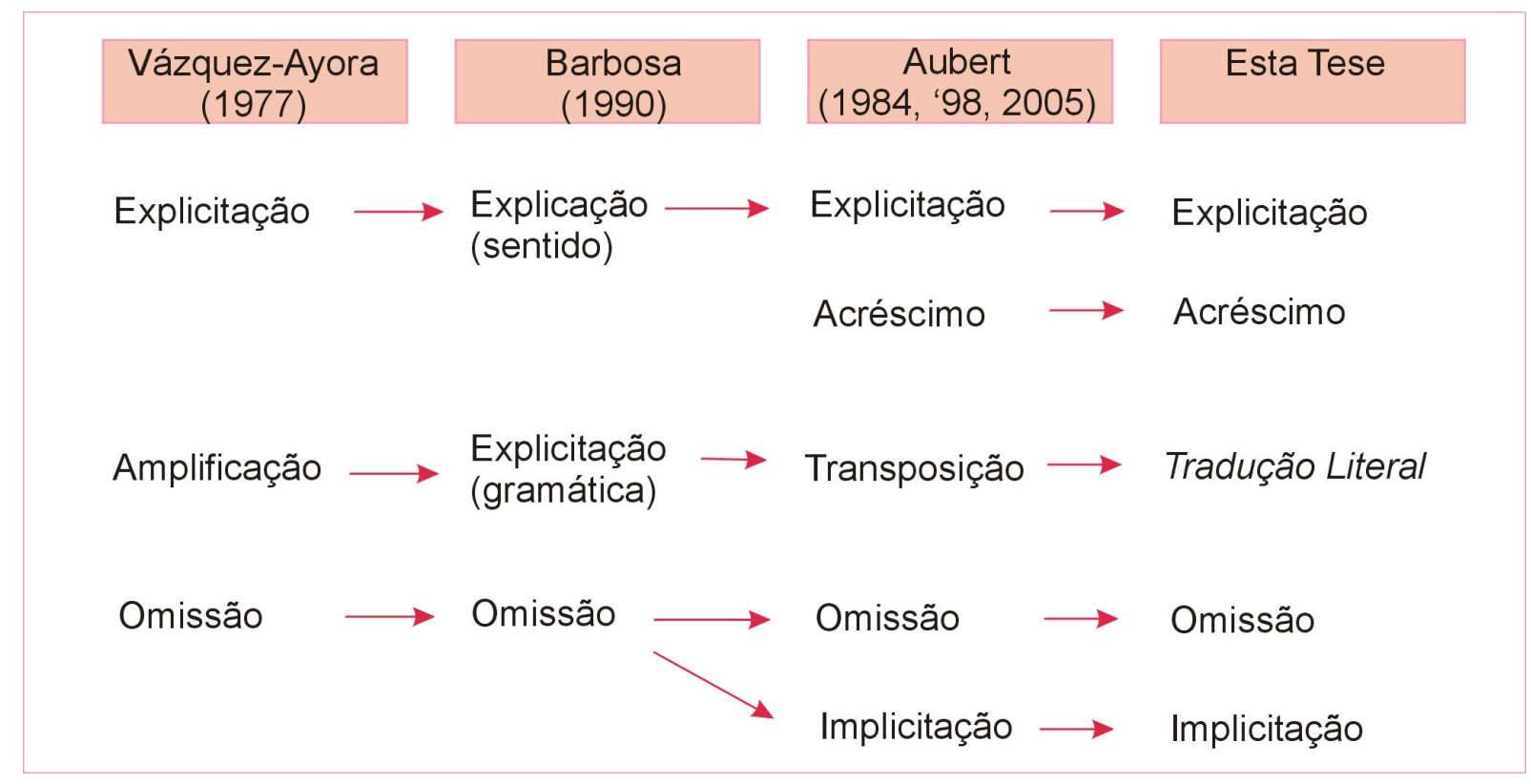

Figura 3.7 - Evolução das categorias explicitação, omissão, implicitação e acréscimo

Nem todos definem explicitação e implicitação desta maneira. Para Klaudy e Károly (2003), "Implicitation occurs, for instance, when a SL unit of a more specific meaning is replaced by a TL unit of a more general meaning". Para os fins desse estudo, a substituição por um termo mais genérico ou mais específico é modulação. E a modalidade acréscimo ocorre quando informação for acrescentada à tradução sem ser implícita no original, e sem ser mais genérica nem mais específica. Um exemplo disso seria a tradução de passbooks por cadernetas e talões, quando passbook é somente caderneta, mas talão é um termo relacionado. Há vários exemplos de acréscimo nos corpora. Aqui, explicitação e implicitação não modificam o sentido do trecho traduzido (conteúdo semântico estável). Omissão e acréscimo são utilizados quando nenhuma equivalência ou modulação explicam a tradução de maneira mais clara.

\subsubsection{Empréstimo, decalque e transcrição}

Decalque é raro na linguagem jurídica, e quando aparece geralmente é um erro de tradução e não algo criativo (no sentido bom) da parte do tradutor. Um exemplo de um decalque marcado como erro (no arquivo pr9) foi a tradução de contrato social como social contract (um termo que não existe no contexto de documentos constitutivos). Barbosa e Aubert acrescentaram várias categorias ou subcategorias para transferência, empréstimo e decalque 
que não vou utilizar, por não serem muito importantes (nem muito comuns) na tradução jurídica. A categoria estrangeirismo + explicação de Barbosa é muito comum, mas com a unidade de estudo maior empregada neste estudo, muitas análises já resultam em combinações de modalidades, e portanto não é necessário criar uma categoria que corresponderia a uma combinação de outras duas. Newmark fala muito desse tipo de dístico (couplet) de dois procedimentos utilizados juntos para traduzir uma única unidade de estudo, geralmente um empréstimo mais um outro procedimento explicativo.

Uma modalidade acrescentada por Aubert, a transcrição, é mantida neste estudo. A transcrição ocorre quando a unidade contém itens que pertencem a ambas as línguas (de partida e de chegada), como algarismos ou palavras importadas de uma língua para outra e já dicionarizadas. Um exemplo é joint venture em português, um empréstimo do inglês já dicionarizado (Houaiss, 2001). A transcrição também se aplica à tradução de palavras e frases que não pertencem nem à língua de chegada nem à língua de partida. Exemplos incluem o uso de latim em linguagem jurídica tanto em inglês quanto em português. Porém, não é tão comum o inglês e o português utilizarem latim nos mesmos contextos.

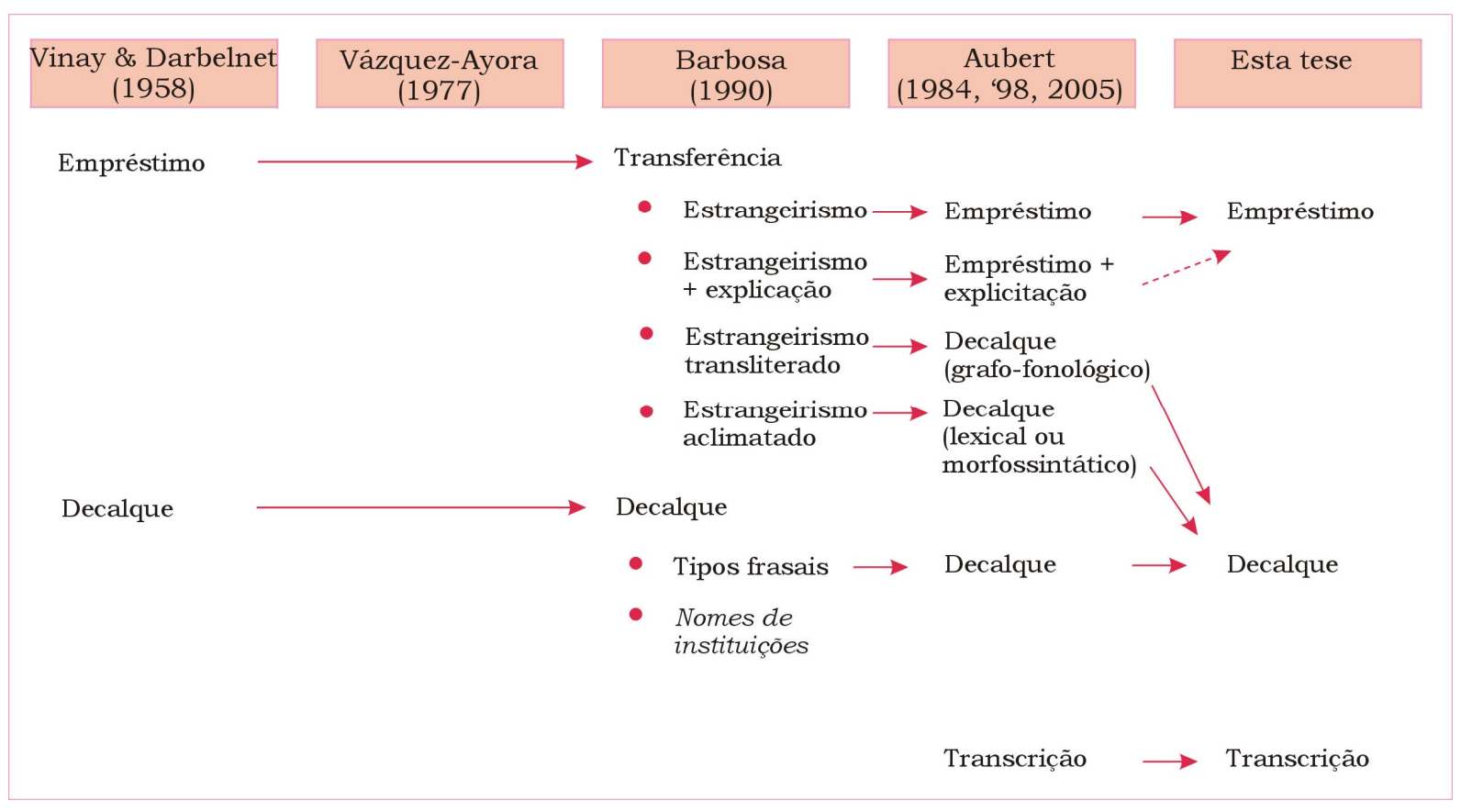

Figura 3.8 - Evolução das modalidades empréstimo, decalque e transcrição 


\subsubsection{Erro e correção}

A modalidade erro é necessária quando se analisa traduções feitas por outros. Erros incluem desentendimentos óbvios (specially/especially), erros de ortografia e repetição de uma palavra duas vezes. A modalidade correção representa o procedimento contrário, quando há um erro óbvio no original e o tradutor corrigiu-o na tradução. Vários dos documentos originais têm inglês incorreto, que os tradutores corrigiram ao traduzir para o português.

\subsubsection{Resumo das modalidades de tradução}

A tabela 3.4 resume as modalidades utilizadas neste estudo.

\begin{tabular}{|c|c|}
\hline tradução literal & $\begin{array}{l}\text { Qualquer tipo de tradução literal, inclusive com transposição } \\
\text { de ordem das palavras, do número de palavras e de categorias } \\
\text { gramaticais. }\end{array}$ \\
\hline modulação & $\begin{array}{l}\text { Uma modulação não especificada pelas subcategorias, como o } \\
\text { negativo do contrário ou o meio pelo resultado. Inclui a } \\
\text { modulação e a equivalência como definidas por Vinay e } \\
\text { Darbelnet. }\end{array}$ \\
\hline $\begin{array}{l}\text { modulação através de } \\
\text { especificação }\end{array}$ & Um termo mais específico é utilizado na tradução. \\
\hline $\begin{array}{l}\text { modulação através de } \\
\text { generalização }\end{array}$ & ais aeral é utilizado n \\
\hline $\begin{array}{l}\text { modulação através do todo } \\
\text { substituído pela parte }\end{array}$ & $\begin{array}{l}\text { Um termo representando um todo é substituído por um termo } \\
\text { representando somente uma parte do todo. }\end{array}$ \\
\hline $\begin{array}{l}\text { modulação através da parte } \\
\text { substituída pelo todo }\end{array}$ & $\begin{array}{l}\text { Um termo representando uma parte de um todo é substituído } \\
\text { por um termo representando o todo. }\end{array}$ \\
\hline equivalência funcional & $\begin{array}{l}\text { Uma palavra não culturalmente marcada é utilizada para } \\
\text { descrever a função de uma palavra culturalmente marcada }\end{array}$ \\
\hline equivalência descritiva & Um objeto é descrito de alguma maneira, talvez fisicamente. \\
\hline equivalência cultural & para um \\
\hline
\end{tabular}




\begin{tabular}{|c|c|}
\hline & $\begin{array}{l}\text { equivalente igualmente culturalmente marcado no idioma de } \\
\text { chegada }\end{array}$ \\
\hline equivalência operacional & $\begin{array}{l}\mathrm{O} \text { objeto, conceito ou entidade na tradução opera de uma } \\
\text { maneira semelhante àquele no documento original. O objeto, } \\
\text { conceito ou entidade existe fora do texto traduzido. }\end{array}$ \\
\hline equivalência discursiva & $\begin{array}{l}\text { Uma palavra ou fraseologia é substituída por outra na } \\
\text { tradução devido à sua função dentro do contexto do } \\
\text { documento, e não em referência a um objeto ou conceito fora } \\
\text { do documento. }\end{array}$ \\
\hline explicitação & Explicitação de sentido na tradução. \\
\hline acréscimo & $\begin{array}{l}\text { Acréscimo de uma ou mais palavras com subseqüente } \\
\text { acréscimo de sentido/informação, sem corresponder a } \\
\text { explicitação de sentido. }\end{array}$ \\
\hline implicitação & Implicitação de sentido na tradução. \\
\hline omissão & $\begin{array}{l}\text { Omissão de uma ou mais palavras com subseqüente perda de } \\
\text { sentido/informação, sem corresponder a implicitação de } \\
\text { sentido. }\end{array}$ \\
\hline empréstimo & $\begin{array}{l}\text { Quando o termo no idioma de partida é utilizado no idioma de } \\
\text { chegada, com ou sem aspas, itálicos, etc. e não é } \\
\text { dicionarizado no idioma de chegada. }\end{array}$ \\
\hline decalque & $\begin{array}{l}\text { Uma expressão é emprestada da língua de partida com a } \\
\text { tradução literal de cada parte, e a expressão resultante não faz } \\
\text { parte das convenções da língua de chegada. }\end{array}$ \\
\hline transcrição & $\begin{array}{l}\text { É tipo especial de empréstimo no qual o termo em questão } \\
\text { pertence a ambos os idiomas (dicionarizado) ou a nenhum dos } \\
\text { dois. }\end{array}$ \\
\hline erro & $\begin{array}{l}\text { Um erro grave ou óbvio foi feito na tradução, como a } \\
\text { repetição de uma palavra ou um erro de matemática, } \\
\text { transcrição ou conversão. }\end{array}$ \\
\hline
\end{tabular}




\begin{tabular}{|l|l|}
\hline correção & $\begin{array}{l}\text { A tradução corrige um erro factual ou de gramática na } \\
\text { tradução. }\end{array}$
\end{tabular}

Tabela 3.4 - Resumo das modalidades deste estudo

\subsubsection{Classificação das categorias segundo o grau de aproximação do receptor ao texto original}

Nas seções 3.2 e 3.3 mencionei a classificação das categorias por Vinay e Darbelnet e por Barbosa. Como a unidade de estudo selecionada para este estudo freqüentemente resulta em múltiplos procedimentos aplicados à mesma unidade, procurei uma melhor maneira de classificação que tomasse em conta esta riqueza de informações.

Os dois extremos de método de tradução desenvolvidos por Schleiermacher são aplicáveis à tradução jurídica. O extremo de aproximar o receptor ao escritor (deixando o texto mais próximo ao original) seria conseguido através do uso de empréstimo e através de interlíngua. O outro extremo seria conseguido através do uso de adaptação, para que o receptor não soubesse que o documento foi uma tradução. Entre estes dois extremos, podemos perceber graus diferentes de aproximação do receptor ao autor e vice-versa, como na figura 3.9. Quando a tradução aproxima o receptor ao original, ele precisa se esforçar mais para entender a mensagem comunicada. 


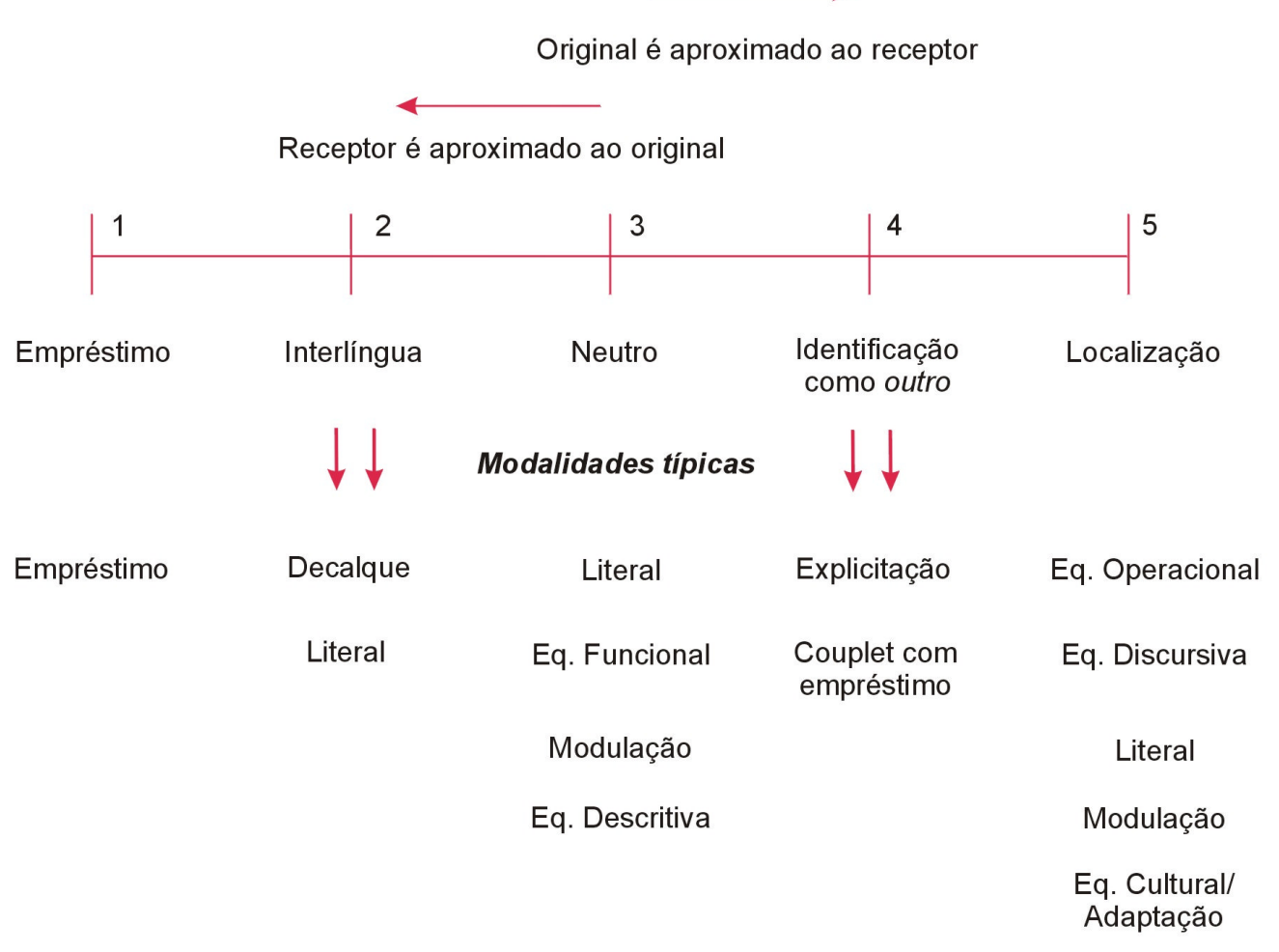

Figura 3.9 - Graus de aproximação do receptor ao escritor do texto original

- empréstimo: Quando a palavra do texto original é traduzida para a tradução, com ou sem aspas. (p.ex. trust traduzido para o português como "trust");

- interlíngua: Quando a tradução não produz uma palavra ou frase comum na língua de chegada (p.ex. cotista traduzido para quotaholder, in witness whereof traduzido para em testemunho do quê);

- neutro: Quando a tradução contém um meio-termo entre o original e a tradução, (p.ex. o uso de um dístico no qual um elemento é um empréstimo;

- identificação como outro: uma tradução na qual o documento mostra a sua alteridade, mas de uma maneira que não atrapalha a comunicação com o receptor;

- localização: uma tradução na qual não há nenhuma indicação de que o documento é uma tradução. 
Observe que as modalidades listadas abaixo de cada categoria de grau de aproximação são só típicas. É necessário determinar o grau de aproximação de cada solução independentemente da classificação da solução através das modalidades, porque as modalidades são utilizadas para analisar a alteração sofrida pela unidade de estudo no original ao ser traduzida, enquanto o método do grau de aproximação coloca mais ênfase no produto, e como esse produto será visto e entendido pelo receptor estrangeiro.

Um exemplo típico das opções de tradução que representam diferentes graus de aproximação (ou dificuldade de comunicação) é a tradução de um tipo de sociedade brasileira para o inglês. A figura 3.10 mostra 5 possíveis traduções para "sociedade limitada".

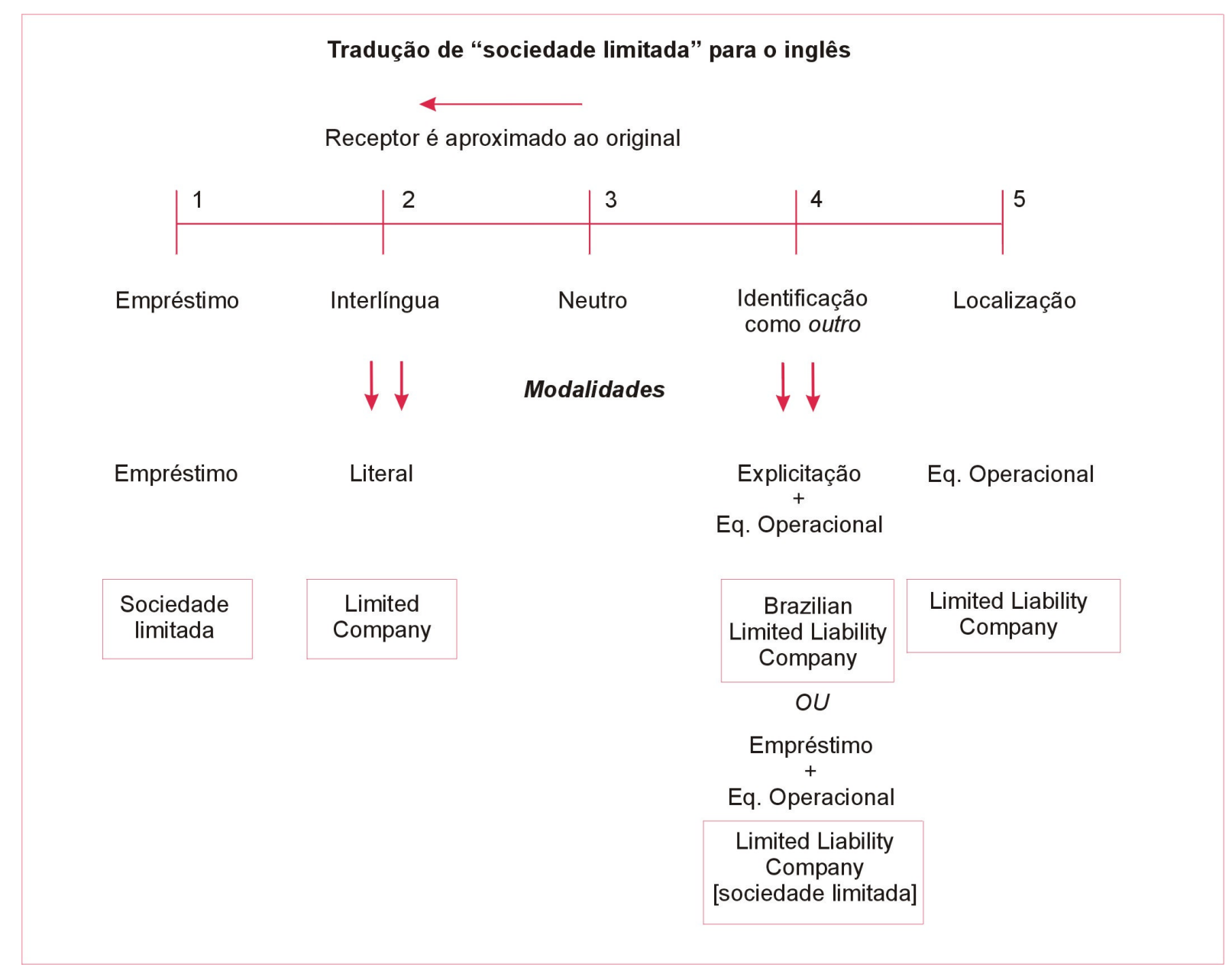

Figura 3.10 - Exemplo de graus de aproximação — sociedade limitada 
Nesse exemplo, a localização (grau 5) é mais fácil para o leitor (de língua inglesa) entender, pois esconde plenamente sua alteridade (na tradução do termo, mas não necessariamente no documento todo). Dependendo do contexto, o leitor pode se enganar e crer que a empresa é norte-americana. A identificação como outro (grau 4) facilita o entendimento do leitor com o uso, no primeiro exemplo, da mesma equivalência operacional mas com um qualificador (nesse caso uma explicitação). A outra solução de grau 4 utiliza a mesma equivalência operacional junto com um empréstimo. Isso mostra a alteridade do termo, mas exige mais trabalho pela parte do leitor que não sabe ler o idioma original. Ele vai saber que a empresa é estrangeira, mas não necessariamente que é brasileira. É uma solução útil quando espera-se a tradução de volta para a língua original. Não há uma solução neutra nesse caso. Isso mostra a alteridade do termo, mas exige mais trabalho pela parte do leitor que não sabe ler o idioma original.

No outro fim do espectro, o empréstimo (grau 1) nesse caso é pouco útil sem uma outra modalidade explicativa. A interlíngua (grau 2), nesse caso uma tradução literal, não corresponde ao termo utilizado nos EUA mas provavelmente seria entendido como uma referência a este tipo de empresa em geral. Não fica claro que a empresa é estrangeira.

A figura 3.11 mostra um outro exemplo dos diferentes graus de aproximação, mas com outras modalidades de tradução representadas nas soluções tradutórias. 


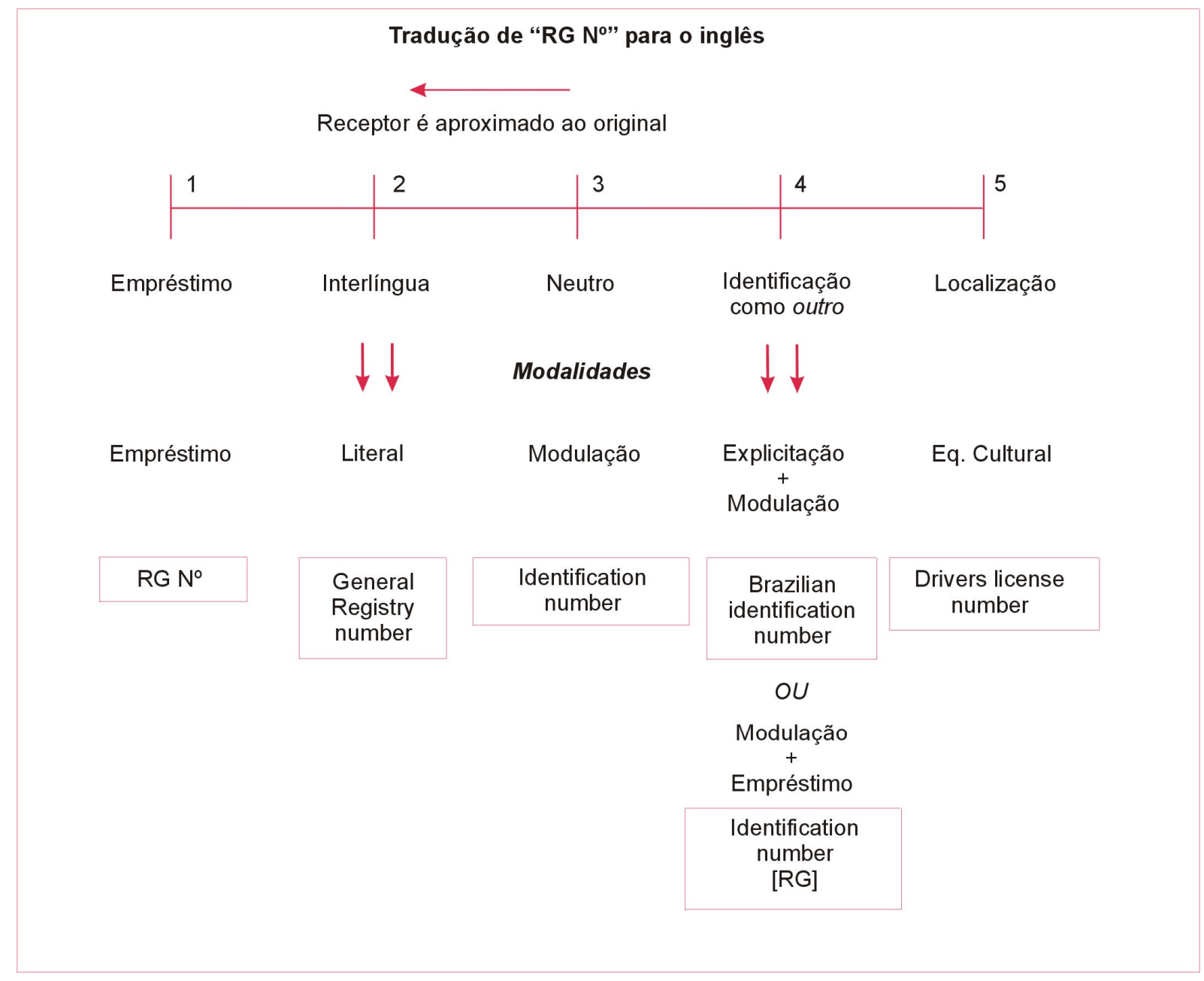

Figura 3.11 - Exemplo de graus de aproximação - RG $N^{o}$

Observe que só as soluções de grau 4 Identification number [RG] e Brazilian identification number foram encontradas nos corpora (entre outras). Porém, a localização (grau 5) seria não só aceitável mas até preferida na situação tradutória $\mathrm{A} 2$, no contexto da qualificação de um norte-americano em vez de um brasileiro.

A figura 3.12 mostra um terceiro exemplo dos diferentes graus de aproximação, esta vez na tradução do termo comarca dentro do contexto "foro da comarca da cidade de São Paulo". 


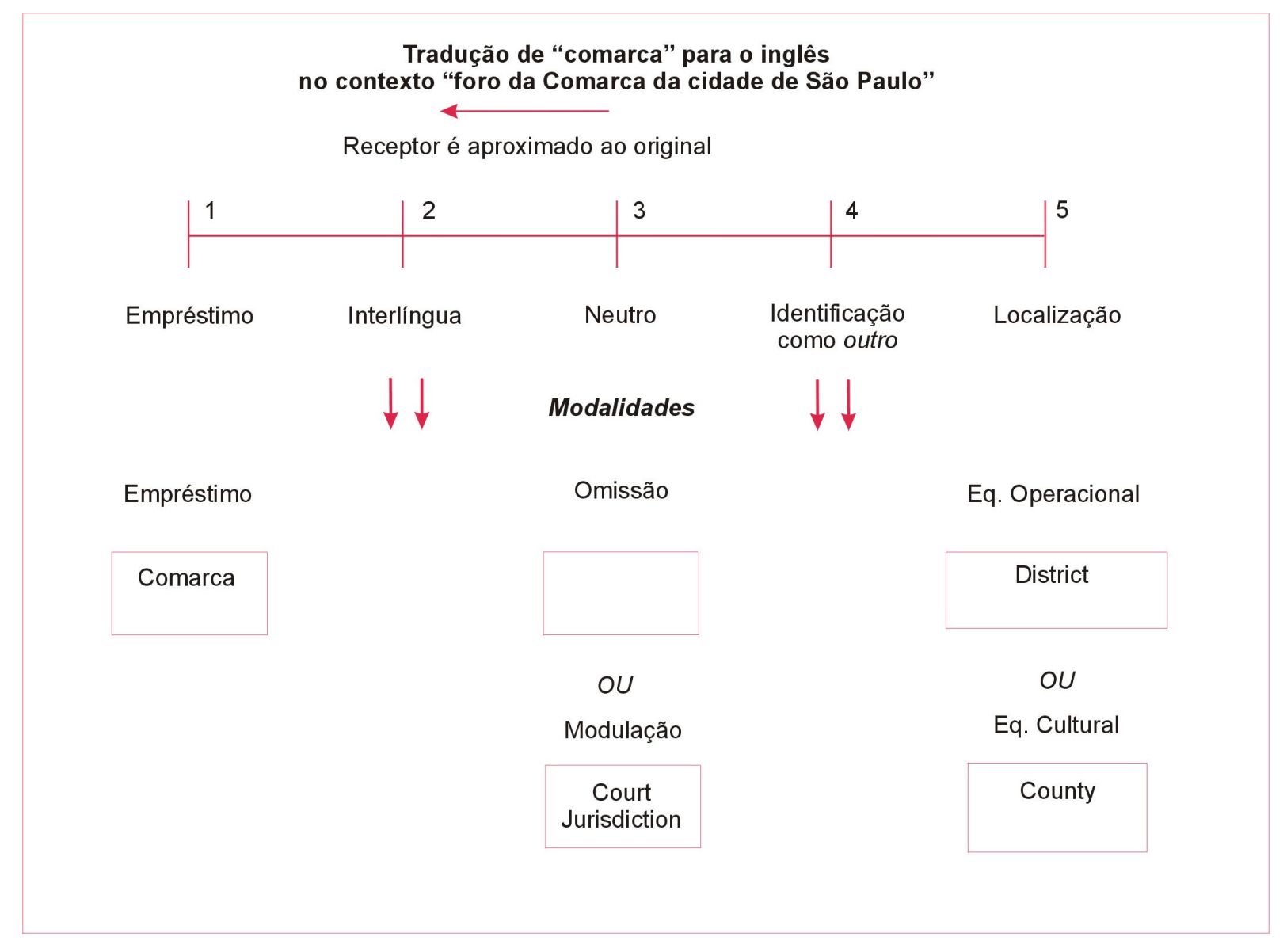

Figura 3.12 - Exemplo de graus de aproximação - Comarca

Perceba novamente que nem sempre há uma solução razoável ou costumeira para cada grau de aproximação. District e judicial district foram as soluções mais utilizadas no corpus, mas em um caso o conceito foi omitido e em outro uma equivalência funcional (administrative region) foi empregada.

Qual tradução (e qual grau de aproximação) é mais apropriada depende da situação tradutória, o objetivo da tradução (definido pelo cliente) e os receptores previstos. Neste estudo, todas as traduções são classificadas como pertencentes a um dos graus, enumerados de 1 (empréstimo) a 5 (localização), baseado em uma análise independente da análise de modalidades. As modalidades na figura 3.9 são somente típicas de cada grau de aproximação. O grau de 
aproximação é mais orientado ao produto do que a classificação por modalidades, pois modalidades caracterizam o processo ou transformação pelo qual passou a unidade de estudo, enquanto o grau de aproximação mede a aproximação do resultado ao receptor. Um bom exemplo disso é a tradução de "United States District Court" para português. Uma tradução que inclua "dos Estados Unidos" seria classificada como grau 4 devido à presença de um sinal de alteridade apesar de ser uma tradução literal. Não importa que essa informação não foi acrescentada pelo tradutor. Porém, a tradução de "corporation" para "sociedade anônima norte-americana" também seria classificada como grau 4, mas nesse caso devido a uma explicitação do país.

Observe que o grau de aproximação não é uma questão apenas da tradução estar orientada ao idioma de chegada ou ao idioma de partida, apesar de ter alguma sobreposição entre grau de aproximação e esse conceito quando se trata de marcadores estilísticos (e as convenções das línguas em questão). É uma questão de alteração de ponto de vista, do receptor original da cultura de partida para o receptor da tradução na cultura de chegada. A diferença se vê mais marcadamente na tradução de marcadores referenciais (extra-lingüísticos) pois, dependendo da situação tradutória, a alteridade do original pode se mostrar de várias maneiras ou pode ser escondida.

Eu proponho estes graus de aproximação somente para tradução jurídico, devido à natureza de seus marcadores culturais. Para tradução médica ou científica, o $4^{\circ}$ grau provavelmente seria supérfluo. 


\section{Metodologia e estabelecimento dos corpora}

Um corpus é uma coleção de textos (não necessariamente textos completos, mas tampouco frases aleatórias) em um formato legível por computador que, como um todo, constitui uma amostra representativa de um idioma em geral ou de linguagem especializada em um dado idioma (p.ex. linguagem jurídica, linguagem médica ou linguagem jornalística). Os textos são analisados por lingüistas como dados de experiência são analisados por físicos, para mostrar fenômenos não aparentes em textos analisados individualmente.

\subsection{Tipos de corpora}

Corpora podem ser categorizados de várias maneiras. Corpora gerais contêm textos que não pertencem a um único gênero, área de conhecimento ou registro. Corpora específicos podem ser tão específicos quanto o projetista desejar, e podem conter, por exemplo, todos os textos de um único autor, todos os textos publicados em uma única revista ou uma coleção de contratos de locação de múltiplas fontes. Esse tipo de corpora também é chamado de corpus especializado.

Além da especificação acima, corpora podem conter textos em apenas um idioma (monolíngüe) ou em dois ou mais idiomas (bilíngüe/multilíngüe). Quando um corpus bilíngüe (ou multilíngüe) contém originais e suas traduções, é um corpus paralelo. Quando um corpus bilíngüe (ou multilíngüe) contém apenas originais, é um corpus comparável, pois os textos nos dois (ou mais) idiomas são análogos e podem ser comparados. O corpus comparável é uma ferramenta poderosa para comparar textos sem as distorções criadas por tradução, ou como contraponto a um corpus paralelo justamente para identificar essas distorções.

Como mencionei na introdução, para este estudo coletei documentos para 4 corpora:

- um corpus paralelo com documentos jurídicos originais em português brasileiro e suas traduções em inglês (br-ing), 
- um corpus paralelo com documentos jurídicos originais em inglês e suas traduções em português brasileiro (ing-br),

- um corpus comparável com documentos jurídicos originais em português brasileiro (br-orig), e

- um corpus comparável com documentos jurídicos originais em inglês americano (ingorig).

\subsection{Considerações no projeto dos corpora}

Para projetar os corpora, levei em conta as considerações de Bowker (2002) quanto aos parâmetros de interesse:

- Tamanho

- Extratos ou textos inteiros

- Número de textos

- Meio (escrito ou originalmente verbal)

- Assunto

- Gênero

- Autor

- $\operatorname{Idioma}(\mathrm{s})$

- Data de publicação

Bowker recomenda que o corpus tenha o número maior possível de palavras. Os corpora paralelos contêm o maior número possível de textos que consegui coletar dentro do prazo estabelecido para o projeto. Os corpora comparáveis poderiam talvez ter sido maiores, mas não eram o foco deste estudo.

Apenas textos inteiros foram utilizados. Houve muita variação quanto ao comprimento dos textos, uma variação que existe no gênero. Não havia como controlar isso, e a distribuição dos documentos quanto ao comprimento foi aleatória. Também não havia como controlar o 
número de textos fornecidos pelos tradutores. Recebi os textos que os colegas estavam dispostos a contribuir.

Todos os textos eram escritos (e não verbais). Os receptores para os textos eram principalmente os advogados das partes interessadas, agências do governo ou o sistema de justiça. Em alguns contextos (especialmente procurações) os documentos poderiam ser tido escritos para serem lidos por leigos. Observe que alguns dos documentos originais já haviam sido direcionados a receptores estrangeiros.

O assunto geral dos corpora é o direito privado, e os gêneros específicos são procurações, contratos e documentos constitutivos. Escolhi estes gêneros porque procurações e contratos sociais são documentos de domínio público, registrados em cartório/junta comercial, portanto o problema de confidencialidade é reduzido. Contratos são o tipo de documento jurídico mais traduzido (pelo menos na minha experiência particular) e por isso mais fáceis de coletar. Muitos dos textos dos corpora comparáveis foram coletadas da Internet, e um esforço foi feito para evitar uma presença forte demais de contratos de licença de software. Recebi doações de documentos sobre o direito comercial e opiniões de juristas, mas não os inclui devido a diferenças de estilo/gênero.

Em todos os casos o autor foi um advogado desconhecido ou o departamento jurídico de uma empresa. Alguns dos textos originais em inglês foram claramente escritos por pessoas cuja língua de domínio mais ativo não era o inglês. As traduções foram analisadas, mas os originais não foram acrescentados ao corpus comparável. Mais importante foi a escolha de tradutores. Pedi contribuições somente de tradutores que já conhecia através de congressos ou trabalhos feito em conjunto. Em alguns casos, um ou outro tradutor forneceu uma tradução do início da carreira e foi rejeitada por ter muitos erros de tradução. O objetivo deste estudo é ver como tradutores profissionais traduzem hoje, e não procurar os erros típicos de tradutores no início de carreira. Tentei coletar traduções do maior número de pessoas possíveis, mas foi difícil, particularmente na coleta de traduções para inglês feitas por norte-americanos ou ingleses. Meu contato com tradutores no exterior é mais limitado. 
Os corpora contêm documentos em português brasileiro e em inglês norte-americano ou do Reino Unido. A maioria dos documentos é de 1995 a 2006, e em alguns casos não foi possível identificar a exata data original.

\subsection{Metodologia de levantamento}

Para este estudo, procurei estudar a tradução jurídica como é feita diariamente, com todas as suas características peculiares. Pedi doações de colegas conhecidos como tradutores de documentos jurídicos e evitei tradutores cuja especialidade fosse outra área. A coleta foi muito difícil devido a questões de confidencialidade, e se estendeu por 2 anos. Mais próximo ao final desse período, comecei a pedir certos gêneros de documentos e traduções com características específicas para ter um corpus equilibrado em termos de número de palavras nos dois sentidos tradutórios e um número relativamente semelhante de palavras por gênero (procuração, contrato, etc.). Seria difícil ampliar o corpus sem conhecer mais tradutores especializados na área jurídica, pagar pelas traduções ou ampliar os critérios descritos na seção 4.2. O objetivo foi estudar as escolhas desses tradutores (presumidamente boas) e não procurar erros.

Apenas um dos tradutores tem formação na área jurídica (de uma faculdade brasileira), e a contribuição desta pessoa em termos de número de palavras foi pouca. Os tradutores dependem de dicionários jurídicos (e gerais) bilíngües como Mello (1998) e dicionários monolíngües como Black's Law Dictionary (Garner, 1999), o Vocabulário Jurídico (Plácido e Silva, s/d) e o Dicionário Jurídico (Diniz, 2005). Eles também trocam idéias através de listas de discussão na Internet e procuram soluções em livros didáticos da área jurídica.

Quanto ao perfil lingüístico e sociocultural dos tradutores, 6 tradutores tinham o inglês como sua língua de domínio mais ativo (LDA) e 9 tinham o português como sua LDA. Todos os tradutores são identificados por uma letra do alfabeto e a letra foi escolhida por uma terceira pessoa (não o pesquisador) para evitar viés nas análises. 
Decidiu-se não descartar traduções em que o documento a ser traduzido estivesse escrito na LDA do tradutor, devido ao fato disso ser uma prática comum no Brasil, e que merece ser estudada. Malmkjær (1993, p. 213) sustenta o argumento de que tradutores experientes "might produce higher degrees of equivalence if they are translating out of their mother tongues than if they are translating into their mother tongues." A diferença entre traduções feitas para a LDA e as feitas a partir da LDA será analisada nas conclusões. Alguns dos tradutores são tradutores públicos e alguns dos documentos contribuídos são traduções juramentadas. A diferença entre traduções juramentadas e não também será analisada nas conclusões.

Tentou-se classificar os documentos segundo as situações tradutórias descritas no capítulo 3 . Porém, em muitos casos o tradutor não se lembrava mais da situação relacionada a cada tradução (ou nunca soube), e nesses casos a situação tradutória foi estimada a partir das características dos documentos. Uma análise por tipo de situação tradutória também será feita nas conclusões.

A grande maioria das procurações em inglês recebidas para análise foi claramente escrita por pessoas com conhecimentos precários de inglês ou (mal) traduzidos para o inglês de outro idioma. No início, pensei em descartá-las, mas julguei melhor manter alguns dos melhores espécimes e só removê-los do corpus comparável de inglês, pois as traduções para o português são válidas. A tradução de volta ao português de documentos oriundos do português e traduzidos para o inglês é muito comum no Brasil, e foi classificada com a situação tradutória D.

\subsection{Descrição dos corpora}

Os arquivos dos corpora foram identificados através de nomes curtos para facilitar a visualização no programa utilizado. São identificados com duas letras indicativas do tipo de documento:

- co para contratos,

- dc para documentos constitutivos de sociedades,

- pr para procurações. 
O número identificador após a letra é consecutivo para aquele tipo de documento. Após a letra e o número consecutivo vem um traço seguido por um código indicador do país de origem do documento. Isso foi necessário para diferenciar entre os documentos em inglês britânico e aqueles em inglês norte-americano. O inglês escrito nos EUA e no Reino Unido é próximo o suficiente para permitir o estudo de marcadores estilísticos sem diferenciar a origem dos documentos. Para o estudo de marcadores referenciais, foi necessário fazer o levantamento jurídico tanto para os EUA quanto para a Grã-Bretanha. Estes códigos são:

- br para o Brasil,

- us para os EUA,

- uk para documentos do Reino Unido.

Em alguns casos, o original não foi escrito por uma pessoa cuja LDA (língua de domínio mais ativo) era o inglês. As descrições dos documentos (seção 4.4.3) explicam como essa classificação foi determinada. Esses documentos são identificados com um "n" colocado após a sigla "us" ou "uk". Não havia nenhum caso de documento original escrito em português por um estrangeiro. No caso de um tradutor traduzindo de sua LDA, o "n" é colocado após a sigla indicativa do país da língua de chegada.

\subsubsection{Ing-br - Traduções do inglês para o português}

O corpus de originais em inglês e suas respectivas traduções para português brasileiro foi chamado de ing-br. Contém 50.199 palavras em inglês e 51.383 palavras em português.

Um resumo dos arquivos no corpus ing-br vem apresentado na tabela 4.1 abaixo.

\begin{tabular}{|l|r|l|l|l|l|}
\hline Arquivo & Palavras & $\begin{array}{l}\text { Título do Documento ou } \\
\text { Descrição }\end{array}$ & Juram. & Tradutor & $\begin{array}{l}\text { Para sua } \\
\text { LDA }\end{array}$ \\
\hline $\begin{array}{l}\text { co1_us- } \\
\text { brnC }\end{array}$ & 371 & Contingent Fee Agreement & não & C & não \\
\hline $\begin{array}{l}\text { co2_us- } \\
\text { brG }\end{array}$ & 5172 & Letter of Pledge of Securities & não & G & sim \\
\hline co3_us- & 4810 & Master Promissory Note & não & G & sim \\
\hline
\end{tabular}




\begin{tabular}{|c|c|c|c|c|c|}
\hline brG & & & & & \\
\hline $\begin{array}{l}\text { co4_us- } \\
\text { brJ }\end{array}$ & 2073 & $\begin{array}{l}\text { Summary of Proposed Terms } \\
\text { and Conditions }\end{array}$ & não & $\mathrm{J}$ & $\operatorname{sim}$ \\
\hline $\begin{array}{l}\text { co5_us- } \\
\text { brJ }\end{array}$ & 2698 & Commercial Agreement & não & $\mathrm{J}$ & $\operatorname{sim}$ \\
\hline $\begin{array}{l}\text { co6_us- } \\
\text { brA }\end{array}$ & 4719 & $\begin{array}{l}\text { Master Software Ordering and } \\
\text { License Agreement }\end{array}$ & não & $\mathrm{A}$ & $\operatorname{sim}$ \\
\hline $\begin{array}{l}\text { co7_usn- } \\
\text { brF }\end{array}$ & 1787 & Confidentiality Agreement & não & $\mathrm{F}$ & $\operatorname{sim}$ \\
\hline $\begin{array}{l}\text { co8_us- } \\
\text { brF }\end{array}$ & 1381 & Warranty & não & $\mathrm{F}$ & $\operatorname{sim}$ \\
\hline $\begin{array}{l}\text { col1_us- } \\
\text { brN }\end{array}$ & 1468 & Software License Agreement & não & $\mathrm{N}$ & $\operatorname{sim}$ \\
\hline $\begin{array}{l}\text { dc1_us- } \\
\text { brE }\end{array}$ & 989 & Articles of Incorporation & $\operatorname{sim}$ & $\mathrm{E}$ & $\operatorname{sim}$ \\
\hline $\begin{array}{l}\text { dc2_uk- } \\
\text { brB }\end{array}$ & 7100 & $\begin{array}{l}\text { Memorandum and Articles of } \\
\text { Association (dois documentos) }\end{array}$ & $\operatorname{sim}$ & $\mathrm{B}$ & $\operatorname{sim}$ \\
\hline $\begin{array}{l}\text { dc3_uk- } \\
\text { brE }\end{array}$ & 2312 & Memorandum of Association & $\operatorname{sim}$ & $\mathrm{E}$ & $\operatorname{sim}$ \\
\hline $\begin{array}{l}\text { dc4_uk- } \\
\text { brE }\end{array}$ & 10638 & Articles of Association & $\operatorname{sim}$ & $\mathrm{E}$ & $\operatorname{sim}$ \\
\hline $\begin{array}{l}\text { pr1_usn- } \\
\text { brM }\end{array}$ & 735 & Power of Attorney & $\operatorname{sim}$ & M & $\operatorname{sim}$ \\
\hline $\begin{array}{l}\text { pr2_us- } \\
\text { brM }\end{array}$ & 966 & General Power of Attorney & $\operatorname{sim}$ & M & $\operatorname{sim}$ \\
\hline $\begin{array}{l}\text { pr3_us- } \\
\text { brB }\end{array}$ & 218 & Power of Attorney & $\operatorname{sim}$ & $\mathrm{B}$ & $\operatorname{sim}$ \\
\hline $\begin{array}{l}\text { pr4_ukn- } \\
\text { brM }\end{array}$ & 771 & Power of Attorney & $\operatorname{sim}$ & $\mathrm{M}$ & $\operatorname{sim}$ \\
\hline
\end{tabular}




\begin{tabular}{|l|r|l|l|l|l|}
\hline pr5_usnE & 216 & Power of Attorney & sim & E & sim \\
\hline $\begin{array}{l}\text { pr6_ukn- } \\
\text { brE }\end{array}$ & 535 & Power of Attorney & sim & E & sim \\
\hline $\begin{array}{l}\text { p7_ukn- } \\
\text { brnL }\end{array}$ & 338 & Power of Attorney & não & L & não \\
\hline $\begin{array}{l}\text { pr8_ukn- } \\
\text { brH }\end{array}$ & 639 & Power of Attorney & não & H & sim \\
\hline $\begin{array}{l}\text { p9_usn- } \\
\text { brB }\end{array}$ & 263 & Power of Attorney & sim & B & sim \\
\hline
\end{tabular}

Tabela 4.1 - Descrição do corpus paralelo ing-br

\subsubsection{Br-ing - Traduções do português para o inglês}

O corpus de originais em português brasileiro e suas traduções para o inglês norte-americano foi denominado br-ing. Contém 51.817 palavras em português e 54.455 palavras em inglês. Os arquivos são identificados utilizando o mesmo esquema utilizado para o corpus ing-br, mas com a simplificação de que não foram localizados originais em português claramente escritos por estrangeiros. Comecei a numeração consecutiva com 50 para permitir o acréscimo de mais arquivos no futuro.

Um resumo dos arquivos no corpus br-ing vem apresentado na tabela 4.2 abaixo:

\begin{tabular}{|l|l|l|l|l|l|}
\hline Arquivo & Palavras & $\begin{array}{c}\text { Título do Documento ou } \\
\text { Descrição }\end{array}$ & Juram. & Tradutor & Para a \\
usL & & $\begin{array}{l}\text { Instrumento particular de } \\
\text { contrato de locação E } \\
\text { Instrumento particular de } \\
\text { cessão de diretos }\end{array}$ & não & L & sim \\
\hline
\end{tabular}




\begin{tabular}{|c|c|c|c|c|c|}
\hline $\begin{array}{l}\text { co51_br- } \\
\text { usD }\end{array}$ & 5549 & $\begin{array}{l}\text { Contrato de locação de imóvel } \\
\text { comercial }\end{array}$ & não & $\mathrm{D}$ & $\operatorname{sim}$ \\
\hline $\begin{array}{l}\text { co52_br- } \\
\text { usK }\end{array}$ & 1840 & $\begin{array}{l}\text { Contrato de representação e } \\
\text { distribuição }\end{array}$ & não & $\mathrm{K}$ & $\operatorname{sim}$ \\
\hline $\begin{array}{l}\text { co53_br- } \\
\text { usnF }\end{array}$ & 1550 & $\begin{array}{l}\text { Aditamento ao contrato } \\
\text { internacional }\end{array}$ & $\operatorname{sim}$ & $\mathrm{F}$ & não \\
\hline $\begin{array}{l}\text { co54_br- } \\
\text { usnF }\end{array}$ & 1492 & Contrato de trabalho & não & $\mathrm{F}$ & não \\
\hline $\begin{array}{l}\text { co55_br- } \\
\text { usnH }\end{array}$ & 1838 & $\begin{array}{l}\text { Contrato de representação } \\
\text { comercial }\end{array}$ & não & $\mathrm{H}$ & não \\
\hline $\begin{array}{l}\text { co56_br- } \\
\text { usD }\end{array}$ & 2359 & $\begin{array}{l}\text { Instrumento particular de } \\
\text { acordo relacionado a locações } \\
\text { de bem imóvel }\end{array}$ & não & $\mathrm{D}$ & $\operatorname{sim}$ \\
\hline $\begin{array}{l}\text { co57_br- } \\
\text { usD }\end{array}$ & 568 & $\begin{array}{l}2^{\circ} \text { aditivo ao instrumento } \\
\text { particular de convenção de } \\
\text { condomínio civil }\end{array}$ & não & $\mathrm{D}$ & $\operatorname{sim}$ \\
\hline $\begin{array}{l}\text { co58_br- } \\
\text { usD }\end{array}$ & 879 & $\begin{array}{l}\text { Instrumento particular de } \\
\text { contrato de cessão de direitos e } \\
\text { obrigações }\end{array}$ & não & $\mathrm{D}$ & $\operatorname{sim}$ \\
\hline $\begin{array}{l}\text { co59_br- } \\
\text { usL }\end{array}$ & 7704 & $\begin{array}{l}\text { Condições gerais de } \\
\text { fornecimento e montagem de } \\
\text { materiais e equipamentos }\end{array}$ & não & $\mathrm{L}$ & $\operatorname{sim}$ \\
\hline
\end{tabular}




\begin{tabular}{|c|c|c|c|c|c|}
\hline $\begin{array}{l}\text { co60_br- } \\
\text { usP }\end{array}$ & 3573 & $\begin{array}{l}\text { Contrato de patrocínio e } \\
\text { condução de pesquisa clínica }\end{array}$ & não & $\mathrm{P}$ & $\operatorname{sim}$ \\
\hline $\begin{array}{l}\text { co61_br- } \\
\text { usQ }\end{array}$ & 3700 & $\begin{array}{l}\text { Contrato de exploração } \\
\text { conjunta de serviços }\end{array}$ & não & $\mathrm{Q}$ & $\operatorname{sim}$ \\
\hline $\begin{array}{l}\text { dc50_br- } \\
\text { usL }\end{array}$ & 1998 & Estatuto social & não & $\mathrm{L}$ & $\operatorname{sim}$ \\
\hline $\begin{array}{l}\text { dc51_br- } \\
\text { usL }\end{array}$ & 692 & $\begin{array}{l}\text { Primeiro instrumento de } \\
\text { alteração de contrato }\end{array}$ & não & $\mathrm{L}$ & $\operatorname{sim}$ \\
\hline $\begin{array}{l}\text { dc52_br- } \\
\text { usD }\end{array}$ & 6314 & $\begin{array}{l}\text { Instrumento particular de } \\
\text { primeira alteração } \\
\text { consolidação de contrato social }\end{array}$ & não & $\mathrm{D}$ & $\operatorname{sim}$ \\
\hline $\begin{array}{l}\text { dc53_br- } \\
\text { usnE }\end{array}$ & 2421 & $\begin{array}{l}\text { Instrumento particular de } \\
\text { primeira alteração } \\
\text { consolidação de contrato social }\end{array}$ & não & $\mathrm{E}$ & não \\
\hline $\begin{array}{l}\text { dc54_br- } \\
\text { usnE }\end{array}$ & 2648 & $\begin{array}{l}\text { Instrumento particular de } \\
\text { terceira alteração do contrato } \\
\text { social }\end{array}$ & $\operatorname{sim}$ & $\mathrm{E}$ & não \\
\hline $\begin{array}{l}\text { pr50_br- } \\
\text { usL }\end{array}$ & 106 & Procuração & não & $\mathrm{L}$ & $\operatorname{sim}$ \\
\hline $\begin{array}{l}\text { pr51_br- } \\
\text { usL }\end{array}$ & 278 & Procuração & não & $\mathrm{L}$ & $\operatorname{sim}$ \\
\hline pr52_br- & 188 & Procuração & $\operatorname{sim}$ & $\mathrm{M}$ & não \\
\hline
\end{tabular}




\begin{tabular}{|l|l|l|l|l|l|}
\hline usnM & & & & & \\
\hline pr53_br- & 540 & Procuração & sim & M & não \\
\hline pr54_br- & 438 & Procuração & & & \\
usnM & & & sim & M & não \\
\hline
\end{tabular}

Tabela 4.2 - Descrição do corpus paralele br-ing

A tabela 4.3 exibe o número de palavras (nos documentos originais) nos corpora paralelos.

\begin{tabular}{|l|c|c|}
\hline Tipo de documento & Originais em inglês & Originais em português \\
\hline Contratos & 24.479 & 36.194 \\
\hline Documentos constitutivos & 21.039 & 14.073 \\
\hline Procurações & 4.681 & 1.550 \\
\hline Totais & 50.199 & 51.817 \\
\hline
\end{tabular}

Tabela 4.3 - Número de palavras nos corpora ing-br e br-ing

A tabela 4.4 apresenta o número de palavras e número de documentos por tradutor.

\begin{tabular}{|c|c|c|}
\hline Tradutor & Número de palavras & Número de documentos \\
\hline A (para a LDA) & 4719 & 1 \\
\hline $\mathrm{B} \quad$ (para a LDA) & 7581 & 3 \\
\hline C (da LDA) & 371 & 1 \\
\hline $\mathrm{D}$ (para a LDA) & 15.669 & 5 \\
\hline $\mathrm{E} \quad$ (para a LDA) & 14.690 & 5 \\
\hline $\mathrm{E} \quad$ (da LDA) & 5.069 & 2 \\
\hline $\mathrm{F}$ (para a LDA) & 3.168 & 2 \\
\hline
\end{tabular}




\begin{tabular}{|l|c|c|}
\hline $\mathrm{F}$ (da LDA) & 3.042 & 2 \\
\hline $\mathrm{G}$ (para a LDA) & 9982 & 2 \\
\hline $\mathrm{H}$ (para a LDA) & 639 & 1 \\
\hline $\mathrm{H}$ (da LDA) & 1.838 & 2 \\
\hline $\mathrm{J}$ (para a LDA) & 4771 & 1 \\
\hline $\mathrm{K}$ (para a LDA) & 1.840 & 6 \\
\hline $\mathrm{L}$ (para a LDA) & 15.920 & 3 \\
\hline $\mathrm{L}$ (da LDA) & 338 & 3 \\
\hline $\mathrm{M}$ (para a LDA) & 2472 & 1 \\
\hline $\mathrm{M}$ (de a LDA) & 1.116 & 1 \\
\hline $\mathrm{N}$ (para a LDA) & 1468 & 1 \\
\hline $\mathrm{P}$ (para LDA) & 3.573 & \\
\hline $\mathrm{Q}$ (para LDA) & 3.700 & 1 \\
\hline
\end{tabular}

Tabela 4.4 - Número de palavras e documentos por tradutor

\subsubsection{Descrições dos arquivos nos corpora paralelos, por tipo}

\section{Procurações}

ing-br — pr1_usn-brM - Power of Attorney

Neste documento, uma empresa norte-americana outorga poderes de gestão a um cidadão brasileiro. Erros de inglês marcam este documento como uma tradução para o inglês. Um exemplo é "...and with relation to any person or public or private institution, including state, provincial or municipal and to sign receipts, ...", no qual os adjetivos são colocados após o substantivo institution, um erro de gramática, e no qual se fala de provincial, quando os Estados Unidos não tem províncias. O estilo é um pouco arcaico, com o uso de termos como IN WITNESS WHEREOF e KNOW ALL MEN BY THESE PRESENTS. Se não tradução, pode ser que o autor tenha começado com um modelo em inglês e preencheu-o com inglês incorreto. É claramente feito para utilização no Brasil, pois as qualificações das partes seguem o estilo brasileiro. A situação tradutória provavelmente foi a D2. 
ing-br - pr2_us-brM - General Power of Attorney/ Durable Power of Attorney

Neste documento, o mandante vive nos EUA e o mandatário no Brasil. Dá ao mandatário poderes gerais. Fala primeiro que é geral, e no final menciona que é Durable e que terá efeito até a morte do mandante. O conceito do Durable Power of Attorney (em que o mandato continua em efeito mesmo na incapacidade do mandatário) não existe no Brasil. O inglês é correto e é possível que o documento tenha sido baseado em um modelo. Este tipo de procuração seria típico entre dois parentes próximos. É claramente feito para utilização no Brasil, pois as qualificações das partes seguem o estilo brasileiro. Como este tipo de documento não existe segundo as leis do Brasil, a situação tradutória foi a C1.

ing-br - pr3_us-brB - Power of Attorney especifico para certas transações

Neste documento, uma empresa norte-americana outorga poderes de gestão a um cidadão brasileiro para certas transações de importação. É claramente feito para utilização no Brasil, pois as qualificações das partes seguem o estilo brasileiro. $\mathrm{O}$ início do documento traz uma declaração do Notary Public dos EUA. A situação tradutória poderia ter sido a C1 ou a D2.

ing-br - pr4_ukn-brM — Power of Attorney para fins judiciais

Nesta procuração da Inglaterra, uma sociedade britânica outorga poderes a advogados brasileiros para representá-la em juízo e perante quaisquer autoridades e para representá-la em outras situações especificadas no documento. O documento contém dois erros de terminologia que o marcam como feito no Brasil: o uso do termo "quotaholder", que não existe na GrãBretanha (nem nos EUA), e o uso do termo "instance" no contexto do sistema jurídico (um falso cognato para instância). O documento até menciona "the 'ad judicia et extra' clause", uma referência à terminologia brasileira. As qualificações das partes seguem o estilo brasileiro. A gramática inglesa é correta em geral. O documento original já contém um tipo de interlíngua entre as duas línguas. Por essa razão, a situação tradutória provavelmente foi a D2.

ing-br - pr5_usn-brE - Power of Attorney 
Nesta procuração, uma empresa brasileira outorga poderes a um cidadão brasileiro para representá-la na assembléia geral ordinária de uma outra empresa. Apesar de o original estar em inglês, há termos em português entre colchetes, como "Annual Meeting of Shareholders [Assembléia Geral Ordinária]" que mostram que este documento foi confeccionado no Brasil ou é uma tradução de um documento brasileiro. As qualificações das partes seguem o estilo brasileiro. Este documento também contém um tipo de interlíngua entre as duas línguas. Por essa razão, a situação tradutória provavelmente foi a D2.

ing-br — pr6_ukn-brE — Power of Attorney

Neste documento, uma empresa estrangeira outorga poderes a um cidadão brasileiro. A procuração é geral, mas também especifica que serve para tratar de questões fiscais. É claramente uma tradução de um original em português, com termos como "civil and commercial companies" que refere à classificação antiga de empresas brasileiras como civis ou comerciais (uma classificação que não existe no Reino Unido). Um outro erro de tradução para o inglês é o uso da palavra "Instance" como tradução de instância. O inglês contém vários erros de gramática, como "To exercise for and in the name of the GRANTOR the rights conferred by law, bylaws by virtue of or attached to the shares held by the GRANTOR representing the corporate capital of the Companies;". Por essa razão, a situação tradutória provavelmente foi a D2.

ing-br — pr7_ukn-brL — Power of Attorney

Neste documento, uma empresa britânica outorga poderes a um cidadão brasileiro para representá-la no Brasil, com poderes plenos e gerais. O documento é claramente uma tradução de um original em português, com o uso de termos como quotaholder e "movable or immovable property", que não existem em inglês. Ele se encaixa na situação tradutória D3.

ing-br — pr8_ukn-brH - Specific Power of Attorney

Neste documento, uma empresa britânica outorga poderes a um cidadão brasileiro para representá-la no Brasil em certas situações relacionadas a uma filial brasileira. O documento original em inglês contém muitas referências a órgãos brasileiros por seus nomes em 
português, como "the Brazilian Federal Revenue ("Receita Federal do Brasil")". Por essa razão, a situação tradutória provavelmente foi a D3.

ing-br — pr9_usn-brB — Specific Power of Attorney

Neste documento, uma empresa norte-americana outorga poderes a cidadãos brasileiros para representá-la em uma licitação. O inglês desse documento é estranho, tanto a respeito do registro "aiming at presenting a proposal(s)" quanto às colocações "being entitled to practice all and any acts" (o binômio comum em inglês é any and all, e não all and any). Devido ao inglês estranho, provavelmente se encaixa na situação tradutória D2.

br-ing — pr50_br-usL — procuração específica

Nesta procuração, uma pessoa jurídica brasileira outorga poderes específicos (a respeito de uma conta bancária) a uma pessoa jurídica estrangeira residente no Brasil. Como não é uma tradução juramentada, pode ter sido a situação tradutória A1 ou C2.

br-ing — pr51_br-usL _ procuração ad judicia

Nesta procuração, uma sociedade limitada brasileira outorga poderes ad judicia (para representá-la em juízo) a vários advogados brasileiros do mesmo escritório de advocacia. Como não é uma tradução juramentada, pode ter sido a situação tradutória A1 ou C2.

br-ing — pr52_br-usnM — procuração especifica

Nesta procuração, uma sociedade estrangeira outorga poderes específicos a mais de uma pessoa jurídica brasileira para representá-la em assembléia geral ordinária de uma sociedade brasileira. A situação tradutória poderia ter sido C1, D1 ou D2.

br-ing — pr53_br-usnM — Procuração específica

Nesta procuração, uma sociedade brasileira outorga poderes a vários cidadãos brasileiros para conduzir transações financeiras em nome de uma sociedade limitada brasileira controlada pela primeira. A procuração foi escrita por um tabelião/escrevente e não preparada por um 
advogado. A situação tradutória é claramente a $\mathrm{C} 1$, pois o documento original foi originalmente escrito em português.

br-ing — pr54_br-usnM — Procuração especifica

Nesta procuração, uma pessoa física brasileira outorga poderes a outra pessoa física brasileira para vender um imóvel localizado nos EUA. A procuração foi escrita por um tabelião/escrevente e não preparada por um advogado. A situação tradutória é claramente a $\mathrm{C} 1$, pois o documento original foi originalmente escrito em português e o destino do documento é sua utilização nos EUA.

\section{Atos constitutivos}

ing-br - dc1_us-brE - Articles of Incorporation

Este documento contém os articles of incorporation de uma empresa norte-americana. É um close corporation, um tipo de sociedade que existe em só alguns estados. O documento é de 1989. A sociedade é de capital fechado. Como é juramentada, encaixa-se na situação tradutória $\mathrm{C} 1$.

ing-br - dc2_uk-brB - Memorandum and Articles of Association

Este documento contém na verdade dois documentos, o Memorandum and Articles of Association de uma sociedade constituída em um país de língua inglesa britânica. É uma sociedade limitada, e uma sociedade "internacional" que não tem o direito de negociar com pessoas residentes no país em questão nem comprar imóveis no país. O objeto da empresa é fazer transações financeiras. O capital social da empresa é fechado. Como é juramentada, encaixa-se na situação tradutória $\mathrm{C} 1$.

ing-br-dc3_uk-brE_-Memorandum of Association

Este documento contém o Memorandum of Association de uma sociedade constituída em um país de língua inglesa britânica. O objeto da sociedade é fazer investimentos. Como é juramentada, encaixa-se na situação tradutória $\mathrm{C} 1$. 
ing-br — dc4_uk-brE - Articles of Association

Este documento contém os Articles of Association da sociedade cujo memorandum é cadastrado como dc3_uk-brE. Como é juramentada, encaixa-se na situação tradutória C1.

br-ing — dc50_br-usL - Estatuto social

Este documento contém o estatuto social de uma entidade sem fins lucrativos constituída no Brasil. Ele se encaixa na situação tradutória A1.

br-ing — dc51_br-usL — Primeiro instrumento de alteração de contrato

Este documento contém apenas as alterações ao contrato social de uma sociedade limitada brasileira. É de 2001. Ele se encaixa na situação tradutória A1.

br-ing — dc52_br-usD - Instrumento particular de primeira alteração e consolidação de contrato social

Este documento contém uma alteração ao contrato social de uma sociedade limitada e depois o contrato social novo com as alterações feitas. É de 2005. Um aspecto estranho é a aparência de termos em inglês no original, como "Contrato de Joint Venture (Joint Venture Agreement)" que dá a impressão do documento original em português ter sido uma tradução originalmente do inglês. Isso é confirmado pela presença do modificador "brasileira" antes do tipo de sociedade (sociedade limitada), que seria implícito em um contrato social brasileiro. Não faz sentido um contrato social brasileiro ser uma tradução de um original em inglês, mas sem saber mais sobre o documento e as empresas envolvidas, teria de ser classificado como a situação tradutória D3. Talvez o documento tenha sido revisado várias vezes pela filial brasileira e pela matriz estrangeira com várias traduções na ida e na volta.

br-ing — dc53_br-usnE — Instrumento particular de primeira alteração e consolidação de contrato social

Este documento contém uma alteração ao contrato social de uma sociedade limitada e depois o contrato social novo com as alterações feitas. É de 2005. A situação tradutória é A1. 
br-ing — dc54_br-usnE — Instrumento particular de terceira alteração de contrato social Este documento contém uma alteração ao contrato social de uma sociedade limitada e depois o contrato social novo com as alterações feitas. É de 2005. Um dos sócios é uma sociedade norte-americana. A situação tradutória é A1.

\section{Contratos}

ing-br — co1_us-brnC - Contingent Fee Agreement

Este documento é um contrato entre um advogado e seu cliente para serviços relacionados a um evento específico. A situação tradutória parece ser a B1, pois a tradução foi provavelmente feita para terceiros.

ing-br — co2_us-brG - Letter of Pledge of Securities

Neste documento, títulos são empenhados como garantia. A situação tradutória parece ser a B1, a tradução foi provavelmente feita para terceiros.

ing-br - co3_us-brG - Master Promissory Note

Este documento é uma Nota Promissória. Uma corporation norte-americana promete pagar um valor a um banco. A situação tradutória parece ser a B1, pois a tradução provavelmente foi feita para terceiros.

ing-br — co4_us-brJ - Summary of Proposed Terms and Conditions

Este contrato é entre 3 sociedades brasileiras e uma sociedade norte-americana para a compra e venda de um sistema. A situação tradutória parece ser a A1 ou a B1.

ing-br — co5_us-brJ — Commercial Agreement

Este contrato é entre 2 sociedades brasileiras e uma sociedade norte-americana para a exportação de mercadoria. Devido à fraseologia tipicamente brasileira no documento em inglês, a situação tradutória deve ser a D3. 
ing-br — co6_us-brA - Master Software Ordering and License Agreement

Este contrato é entre uma sociedade norte-americana, o licenciador, e uma sociedade brasileira, o licenciado. A situação tradutória se encaixa na B1.

ing-br — co7_usn-brF — Confidentiality Agreement

Este contrato é entre uma empresa estrangeira e uma empresa brasileira. Trata da questão de confidencialidade a respeito de uma transação. Parece se encaixar na situação tradutória A2.

ing-br - co8_us-brF — Warranty for Product

Este documento é uma garantia para um produto. A garantia foi traduzida para o português para o mercado brasileiro. Ele se encaixa na situação tradutória A2.

ing-br — co11_us-brN — Software License Agreement

Este contrato é entre uma sociedade norte-americana (fornecedor) e uma sociedade brasileira não indicada (licenciada). A tradução foi feita para utilização dentro do Brasil. A situação tradutória é a A2.

br-ing — co50_br-usL - Instrumento particular de contrato de locação E Instrumento particular de cessão de diretos

Estes dois documentos, entre as mesmas partes (pessoas físicas, os locadores, e uma sociedade limitada, a locatária) são para a locação de imóvel comercial e sua renovação. Eles se encaixam na situação tradutória B1.

br-ing — co51_br-usD — Contrato de locação de imóvel comercial

Neste documento, uma empresa brasileira filial de uma empresa estrangeira, aluga um imóvel comercial a uma sociedade anônima brasileira. Como a filial da empresa estrangeira é a autora do documento, a situação tradutória provavelmente foi a A1 (mas possivelmente B1).

br-ing — co52_br-usK — Contrato de representação e distribuição 
Este contrato é entre uma sociedade brasileira (o autor) e uma sociedade estrangeira. A tradução foi feita para servir de modelo para contratos feitos entre a sociedade brasileira e sociedades norte-americanas. Ele se encaixa na situação tradutória A2.

br-ing — co53_br-usnF — Aditamento ao contrato internacional

Este contrato de compra e venda é entre uma sociedade norte-americana e uma brasileira. Devido às referências no documento, a situação tradutória foi a D2.

br-ing — co54_br-usnF — Contrato de trabalho

Este contrato é entre uma sociedade brasileira e uma pessoa física brasileira. A situação tradutória provavelmente foi a A1.

br-ing — co55_br-usnH — Contrato de representação comercial

Este contrato de representação é entre duas sociedades limitadas brasileiras. Ela deve se encaixar na situação A1 ou na B1.

br-ing — co56_br-usD - Instrumento particular de acordo relacionado a locações de bem imóvel

Este contrato é entre 4 sociedades brasileiras - três limitadas e 1 anônima. A situação tradutória é a A1 ou a B1.

br-ing — co57_br-usD - $2^{\circ}$ aditivo ao instrumento particular de convenção de condomínio civil

Este contrato é entre duas sociedades brasileiras - uma limitada e uma anônima. O objeto é a venda de unidades do empreendimento a um terceiro. A situação tradutória é a A1 ou a B1.

br-ing _ co58_br-usD - Instrumento particular de contrato de cessão de direitos e obrigações

Duas sociedades brasileiras cedem direitos a uma terceira sociedade brasileira. A situação tradutória é a A1 ou a B1. 
br-ing - co59_br-usL - Condições gerais de fornecimento e montagem de materiais e equipamentos

Estes termos são entre uma sociedade anônima brasileira (a fornecedora) e uma empresa estrangeira. A situação tradutória é a B1.

br-ing — co60_br-usP — Contrato de patrocínio e condução de pesquisa clínica

Este contrato de patrocínio é entre a patrocinadora (uma sociedade brasileira), a instituição (brasileira) e o investigador principal. Rege a condução do estudo e as condições de pagamento. A situação tradutória é a A1.

br-ing — co61_br-usQ — Contrato de exploração conjunta de serviços

Este contrato de parceria é entre duas empresas brasileiras. A tradução certificada foi feita para terceiros no exterior. A situação tradutória é a C2.

\subsubsection{Corpora comparáveis}

Dois corpora comparáveis foram coletados e utilizados para enriquecer as análises. Eles incluem os documentos originais dos corpora paralelos (com a exceção dos documentos marcados como não escritos por pessoas cuja língua de domínio mais ativo fosse o inglês no caso do corpus comparável de documentos em inglês). A interligação entre os corpora vem mostrada na figura 1.2 da Introdução.

\section{Corpus comparável br-orig}

O corpus comparável de documentos jurídicos privados em português brasileiro contém 190.048 palavras. Os documentos que têm traduções foram descritos acima, e os documentos que pertencem apenas ao corpus comparável estão descritos na tabela 4.5 abaixo. 


\begin{tabular}{|c|c|c|c|}
\hline $\begin{array}{l}\text { Nome do } \\
\text { arquivo }\end{array}$ & Descrição ou título do documento & $\begin{array}{c}\text { Ano (baseado nas } \\
\text { datas no } \\
\text { documento) }\end{array}$ & $\begin{array}{l}\text { Número } \\
\text { de } \\
\text { palavras }\end{array}$ \\
\hline co200_br & $\begin{array}{l}\text { Contrato de prestação de serviços de } \\
\text { administração de condomínios }\end{array}$ & 1999 & 1203 \\
\hline co201_br & Contrato de seguro saúde & 2005 & 13062 \\
\hline co202_br & $\begin{array}{l}\text { Contrato de experiência (para trabalho como } \\
\text { zelador) }\end{array}$ & 1997 & 344 \\
\hline co203_br & $\begin{array}{l}\text { Convenção coletiva de trabalho (Empregados } \\
\text { em edifícios) }\end{array}$ & 2003 & 4739 \\
\hline co204_br & $\begin{array}{l}\text { Contrato de prestação de serviços (obras em } \\
\text { edifício) }\end{array}$ & 2005 & 446 \\
\hline co205_br & Contrato de empreitada & 2004 & 3117 \\
\hline co206_br & Contrato como associado (cartão de crédito) & 2005 & 5773 \\
\hline co207_br & $\begin{array}{l}\text { Solicitação de prestação de serviços (débito } \\
\text { automático) }\end{array}$ & 2000 & 735 \\
\hline co208_br & Contrato de uso de traveller's checks & 2002 & 345 \\
\hline co209_br & Condições para seguro saúde & 1999 & 2454 \\
\hline co210_br & $\begin{array}{l}\text { Contrato de adesão a produtos e serviços } \\
\text { (abertura de conta-corrente) }\end{array}$ & 2001 & 602 \\
\hline co211_br & Contrato de assistência médica hospitalar & 2003 & 930 \\
\hline co212_br & Termo de internação e responsabilidade & 2005 & 951 \\
\hline co213_br & Contrato de câmbio de compra & 2005 & 1307 \\
\hline co215_br & $\begin{array}{l}\text { Contrato de prestação de serviços de } \\
\text { tratamento veterinário }\end{array}$ & 2005 & 981 \\
\hline
\end{tabular}




\begin{tabular}{|c|c|c|c|}
\hline co216_br & $\begin{array}{l}\text { Instrumento Particular de Compromisso de } \\
\text { Venda e Compra de Imóvel e Outras Avenças }\end{array}$ & 2004 & 2603 \\
\hline co218_br & Termo de Cooperação Técnico-Científica & 1998 & 735 \\
\hline co219_br & $\begin{array}{l}\text { Contrato de Realização de Estudos e Pesquisas } \\
\text { Teóricas e Aplicadas }\end{array}$ & 2001 & 1963 \\
\hline co220_br & Contrato de Locação Comercial & 2004 & 1157 \\
\hline co221_br & Contrato de Locação & 2003 & 2488 \\
\hline co222_br & Contrato de Serviço Artístico & 2002 & 1181 \\
\hline co223_br & Contrato de prestação de serviço & $200 ?$ & 747 \\
\hline co224_br & Contrato de prestação de serviço & $200 ?$ & 785 \\
\hline co225_br & Contrato de Arrendamento Mercantil & 2005 & 1094 \\
\hline co226_br & Contrato de Prestação de Serviços & $200 ?$ & 1094 \\
\hline co227_br & Contrato de Adesão & $?$ & 995 \\
\hline co228_br & $\begin{array}{l}\text { Contrato de Intermediação de Operações } \\
\text { Realizadas na Bolsa de Mercadorias e Futuro }\end{array}$ & 2004 & 1891 \\
\hline co229_br & Contrato de Prestação de Serviços & 2003 & 2151 \\
\hline co230_br & Acordo de Prestação de Serviços Via Internet & $?$ & 663 \\
\hline co231_br & Contrato de Adesão Para Assinantes & 2005 & 1295 \\
\hline co232_br & $\begin{array}{l}\text { Contrato de Adesão Para Prestação de } \\
\text { Serviços Educacionais }\end{array}$ & 2004 & 1325 \\
\hline co233_br & Contrato de Gestão & 2002 & 1845 \\
\hline co234_br & $\begin{array}{l}\text { Contrato de licença de uso de programa de } \\
\text { computador }\end{array}$ & 2005 & 1903 \\
\hline co235_br & $\begin{array}{l}\text { Contrato de Licença de Uso e Prestação de } \\
\text { Serviços de Software }\end{array}$ & $?$ & 1533 \\
\hline co236_br & Contrato de Outorga de Bolsa Restituível & $?$ & 803 \\
\hline co237_br & Contrato de Parceria & 2004 & 1558 \\
\hline co238_br & Contrato de Parceria Comercial e Serviços & 2005 & 813 \\
\hline
\end{tabular}




\begin{tabular}{|c|c|c|c|}
\hline co239_br & Contrato de Prestação de Serviço & $?$ & 1733 \\
\hline co240_br & Contrato de Prestação de Serviços & 2005 & 1072 \\
\hline co241_br & $\begin{array}{l}\text { Contrato de Prestação de Serviços de Agente } \\
\text { de Custódia }\end{array}$ & $200 ?$ & 1021 \\
\hline co242_br & $\begin{array}{l}\text { Contrato de Prestação de Serviços de e- } \\
\text { Procurement }\end{array}$ & $?$ & 2613 \\
\hline co243_br & $\begin{array}{l}\text { Contrato de Prestação de Serviços de } \\
\text { Informação, Assessoria e Outras Avenças }\end{array}$ & $?$ & 1244 \\
\hline co244_br & Contrato de Provisão de Acesso à Internet & $?$ & 1438 \\
\hline co245_br & Contrato de Representação Comercial & 2004 & 798 \\
\hline co246_br & $\begin{array}{l}\text { Contrato de Veiculação de Publicidade Por } \\
\text { Meio de Banner }\end{array}$ & $200 ?$ & 627 \\
\hline co247_br & Contrato Milhas de Incentivo & $?$ & 1792 \\
\hline co248_br & Contrato Padrão de Propósitos & $200 ?$ & 1540 \\
\hline co249_br & $\begin{array}{l}\text { Contrato Para Registro de Nome de Domínio } \\
\text { Sob o ".Br" }\end{array}$ & 2005 & 1460 \\
\hline co250_br & $\begin{array}{l}\text { Contrato Particular de Cessão de Direitos e } \\
\text { Obrigações de Registro de Domínio }\end{array}$ & $?$ & 1926 \\
\hline co251_br & Contrato de Acesso à Internet & $200 ?$ & 1663 \\
\hline co252_br & $\begin{array}{l}\text { Fluxo de Caixa - Contrato de Prestação de } \\
\text { Serviços }\end{array}$ & $?$ & 542 \\
\hline co253_br & $\begin{array}{l}\text { Instrumento Particular de Contrato de } \\
\text { Fornecimento de Produtos a Revendedor } \\
\text { Ambulante Autônomo }\end{array}$ & $?$ & 2212 \\
\hline co254_br & Proposta Para Prestação de Serviços & 2005 & 1255 \\
\hline co255_br & Proposta/Orçamento & 2004 & 954 \\
\hline co256_br & Contrato de Prestação de Serviços & 2000 & 1008 \\
\hline co257_br & Contrato de Locação de Stands & $200 ?$ & 1556 \\
\hline
\end{tabular}




\begin{tabular}{|c|c|c|c|}
\hline co258_br & Contrato de Associação & $?$ & 844 \\
\hline co259_br & Contrato de Prestação de Serviço & 2005 & 720 \\
\hline co260_br & Contrato de Pesquisa & $200 ?$ & 1134 \\
\hline co261_br & $\begin{array}{l}\text { Contrato Entre a Financiadora de Estudos e } \\
\text { Projetos e XX }\end{array}$ & $200 ?$ & 2010 \\
\hline co262_br & Contrato de Fomento Mercantil & $200 ?$ & 1917 \\
\hline co264_br & $\begin{array}{l}\text { Instrumento Particular de Contrato de Locação } \\
\text { de Prédio Urbano Para Fins Não Residenciais }\end{array}$ & 2005 & 3317 \\
\hline co265_br & Contrato de Locação & 2003 & 2469 \\
\hline co266_br & Contrato de Locação Comercial & 2004 & 1141 \\
\hline co267_br & Contrato de Licença de Software & 2001 & 5037 \\
\hline co268_br & $\begin{array}{l}\text { Contrato de Cessão de Direitos de Captação, } \\
\text { Exibição, Fixação e Transmissão de Sons e } \\
\text { Imagens }\end{array}$ & 2004 & 2625 \\
\hline co269_br & Contrato de Fornecimento & 2006 & 2458 \\
\hline co270_br & $\begin{array}{l}\text { Instrumento Particular de Prestação de } \\
\text { Serviços de Telecomunicações }\end{array}$ & 2006 & 4268 \\
\hline co271_br & Contrato de Prestação de Serviços & 2006 & 866 \\
\hline dc200_br & $\begin{array}{l}\text { Instrumento Particular de Constituição de } \\
\text { Sociedade Limitada }\end{array}$ & 2000 & 625 \\
\hline dc201_br & 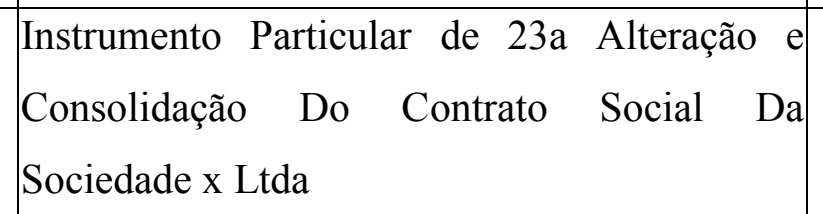 & 2006 & 3539 \\
\hline dc202_br & $\begin{array}{l}\text { Protocolo e Justificação da Incorporação Da } \\
\text { Sociedade x Ltda. }\end{array}$ & 2006 & 1830 \\
\hline dc203_br & $\begin{array}{l}4^{\mathrm{a}} \text { Alteração Do Contrato Social Da Sociedade } \\
\text { Limitada Denominada SociedadeX Ltda. }\end{array}$ & 2003 & 2094 \\
\hline dc204_br & $\begin{array}{l}1^{\mathrm{a}} \text { Alteração Contratual de } \\
\text { Limitada }\end{array}$ & 2006 & 1517 \\
\hline
\end{tabular}




\begin{tabular}{|l|l|c|r|}
\hline dc205_br & Estatuto Social & 2004 & 4038 \\
\hline pr200_br & Procuração & 2005 & 168 \\
\hline pr201_br & Procuração Ad Judicia & 2005 & 195 \\
\hline pr202_br & Procuração & 1994 & 594 \\
\hline pr203_br & Procuração & 2005 & 117 \\
\hline pr204_br & Procuração & $1990 s ?$ & 466 \\
\hline pr205_br & Procuração & $1990 s ?$ & 450 \\
\hline pr206_br & Procuração & 2006 & 341 \\
\hline & NÚMERO TOTAL DE PALAVRAS & & $\mathbf{1 3 8 . 8 4 5}$ \\
\hline
\end{tabular}

Tabela 4.5 - Descrição dos arquivos no corpus comparável br-orig

\section{Corpus comparável ing-orig}

O corpus comparável de documentos jurídicos privados em inglês contém 154.176 palavras. Os documentos que têm traduções foram descritos acima, e os documentos que pertencem apenas ao corpus comparável estão descritos na tabela 4.6 abaixo.

\begin{tabular}{|l|l|c|r|}
\hline $\begin{array}{c}\text { Nome do } \\
\text { arquivo }\end{array}$ & \multicolumn{1}{|c|}{ Descrição / título do documento } & $\begin{array}{c}\text { Ano (baseado } \\
\text { nas datas no } \\
\text { documento) }\end{array}$ & Palavras $^{\mathbf{0}}$ \\
\hline co100_us & Passenger ticket & $2000 ?$ & 1639 \\
\hline co101_us & Terms and conditions & $? ? ?$ & 3004 \\
\hline co102_us & Independent contractor consulting agreement & 2005 & 1809 \\
\hline co103_us & Services agreement & $? ? ?$ & 530 \\
\hline co104_us & Non-disclosure, non-circumvention \& non- & $? ? ?$ & 1211 \\
\hline co105_us & Translation agreement & 2005 & 1062 \\
\hline co106_us & Non-disclosure / non-compete agreement & 2002 & 1046 \\
\hline
\end{tabular}




\begin{tabular}{|c|c|c|c|}
\hline co107_us & $\begin{array}{l}\text { Nondisclosure agreement and statement of } \\
\text { professional ethics }\end{array}$ & $? ? ?$ & 173 \\
\hline col08_us & Terms of agreement & $? ? ?$ & 607 \\
\hline co109_us & Nondisclosure agreement & $? ? ?$ & 156 \\
\hline col10_us & Confidentiality and non-compete agreement & $? ? ?$ & 215 \\
\hline col11_us & Sub-contractor agreement & 2000 & 703 \\
\hline col12_us & Personal property loan agreement & $200 ?$ & 1157 \\
\hline col13_us & Software license agreement & $?$ & 2122 \\
\hline col14_us & Research agreement between two universities & 1988 & 739 \\
\hline col15_us & Agreement (waste treatment and disposal) & 2003 & 2587 \\
\hline col16_us & Affiliation agreement (field work experience) & 2000 & 969 \\
\hline col17_us & Motor vehicle/personal property loan agreement & 2004 & 897 \\
\hline col18_us & Software license agreement & $?$ & 1259 \\
\hline col19_us & Service agreement (internationalization) & 2005 & 1675 \\
\hline col20_us & Asset purchase and sale agreement & 1997 & 3703 \\
\hline co121_us & Broker agreement & 2006 & 533 \\
\hline col22_us & Bill of transfer & 2005 & 303 \\
\hline col23_us & Master lease & 1996 & 24819 \\
\hline co124_us & Lease agreement & 1998 & 32023 \\
\hline co125_us & Proprietary agreement & 2006 & 290 \\
\hline co126_us & Non-disclosure/non-compete agreement & 2006 & 367 \\
\hline col27_us & Lease summary & $200 ?$ & 1568 \\
\hline co128_us & Confidentiality agreement & 2006 & 367 \\
\hline \multirow[t]{2}{*}{ col29_us } & Personal umbrella liability policy & 2003 & 4609 \\
\hline & NÚMERO TOTAL DE PALAVRAS & & 92.142 \\
\hline
\end{tabular}

Tabela 4.6 - Descrição dos arquivos no corpus comparável ing-orig 


\subsection{Metodologia de análise}

O início e o final de todos os documentos foram analisados sentença por sentença, para identificar marcadores estilísticos (expressões e fraseologias) que tendem a se agrupar justamente no início e no final de documentos jurídicos. Devido ao número elevado de palavras não foi possível analisar tudo dessa maneira.

Após identificar termos e estruturas de interesse, foi feita uma busca de palavras-chave nos textos com uma ferramenta para corpora paralelos. Muitas vezes uma busca para um item realçou outro item de interesse próximo ao primeiro. Os programas LogiTerm da empresa canadense Terminotix e MultiTrans da empresa também canadense MultiCorpora foram utilizados para buscar termos nos corpora paralelos. Ambos incluem ferramentas para alinhamento automático que funcionam muito bem. Observe que as buscas foram feitas tanto nos originais quanto nas traduções. Portanto, às vezes a unidade de estudo no documento original não representava um marcador cultural, mas na tradução sim. Os marcadores foram sempre procurados nos dois corpora, para se ter uma visão global do problema e de suas soluções.

Em análises em que a referência a um corpus comparável poderia ajudar a classificar e entender a solução encontrada, uma busca de uma palavra-chave foi empregada com o uso de um de dois programas criados para análise de corpora monolíngües: AntConc (http://www.antlab.sci.waseda.ac.jp/software.html, da Universidade de Waseda no Japão) e TextSTAT (http://www.niederlandistik.fu-berlin.de/textstat/software-en.html, do departamento de holandês da Universidade Livre de Berlim).

Referências jurídicas, inclusive dicionários jurídicos, livros-textos na área jurídica e manuais de estilo jurídico foram consultados para ajudar na classificação das traduções segundo as modalidades apresentadas no capítulo 3. Os livros de estilo foram particularmente úteis para identificar fraseologias e entendê-las, assim como suas traduções. 


\subsubsection{Análise de modalidades}

Os exemplos vem apresentados em tabelas que incluem o original, a tradução, o nome do arquivo (que contém a letra identificadora do tradutor) e o número de vezes que o mesmo par (original e tradução) aparece naquele arquivo. Quando exemplos dos corpora comparáveis são apresentados em tabelas, somente o número do arquivo e o texto são apresentados. O formato dos nomes dos arquivos foi apresentado na seção 4.4. Cada unidade estudada é marcada no original e na tradução com sublinhado, duplo sublinhado, itálico ou negrito, exceto no caso em que há somente uma unidade na célula, apresentada sem contexto (para facilitar a leitura do texto). O sublinhado foi a marcação mais utilizada por ser mais fácil de ver na página impressa.

Este exemplo mostra três unidades de estudo, uma marcada com sublinhado, outra marcada com negrito e a terceira marcada com itálico. Os superscritos são os códigos que identificam a modalidade (ou modalidades) utilizada.

\begin{tabular}{|l|l|l|}
\hline Arquivo & Original & Tradução \\
\hline co2_us-brG & if a corporation, partnership & caso seja uma sociedade anônima $^{\mathrm{EF}}$, \\
& or other organization, & sociedade $^{\mathrm{MG}}$ ou outra pessoa \\
& & jurídica $^{\mathrm{M}}$ \\
\hline
\end{tabular}

O próximo exemplo mostra um caso em que a unidade estudada é todo o texto apresentado, e por isso nenhum trecho específico vem marcado. O número em parênteses após o número do arquivo indica o número de ocorrências da mesma tradução dentro desse arquivo.

\begin{tabular}{|l|l|l|}
\hline Arquivo & Original & Tradução \\
\hline dc51_br-usL & sociedade por quotas de & limited liability company ${ }^{\mathrm{EF}}$ \\
$(2)$ & responsabilidade limitada & \\
\hline
\end{tabular}

No exemplo abaixo, as duas unidades de estudo no original são parcialmente mescladas na tradução. A palavra "sociedade" na tradução é tanto sublinhada quanto destacada com negrito. 


\begin{tabular}{|l|l|l|}
\hline Arquivo & Original & Tradução \\
\hline dc3_uk-brE & of any company or corporation & $\begin{array}{l}\text { qualquer sociedade comercialM ou } \\
\text { anônimaED }\end{array}$ \\
\hline
\end{tabular}

Cada unidade estudada é marcada com um código que indica a modalidade de tradução, seguindo o esquema apresentado na seção 3.4. Quando mais de uma modalidade é utilizada para a mesma unidade, ambas são indicadas, com um hífen para separá-las.

Exemplo no qual duas modalidades foram utilizadas simultaneamente na mesma unidade.

\begin{tabular}{|l|l|l|}
\hline Arquivo & Original & Tradução \\
\hline dc52_br-usD & sociedade limitada brasileira & limited liability company \\
\hline
\end{tabular}

Às vezes, no caso de omissão, não há em que colocar a abreviação $\mathrm{O}$, e a anotação < omissão> é utilizada no texto da tradução.

\begin{tabular}{|l|l|l|}
\hline Arquivo & Original & Tradução \\
\hline co11_us-brN & $\begin{array}{l}\text { NOW, THEREFORE, in } \\
\text { consideration of... }\end{array}$ & $<$ omissão> Tendo em vista as... \\
\hline
\end{tabular}

A tabela 4.7 abaixo resume os códigos para as modalidades, em ordem alfabética por código.

\begin{tabular}{|c|c|}
\hline $\begin{array}{c}\text { Código } \\
\text { identificador }\end{array}$ & Modalidade \\
\hline $\mathrm{AC}$ & Acréscimo \\
\hline $\mathrm{AD}$ & Adaptação \\
\hline $\mathrm{C}$ & Correção \\
\hline $\mathrm{D}$ & Decalque \\
\hline
\end{tabular}




\begin{tabular}{|c|c|}
\hline $\mathrm{EC}$ & Equivalência cultural \\
\hline EDV & Equivalência discursiva \\
\hline $\mathrm{EDE}$ & Equivalência descritiva \\
\hline EF & Equivalência funcional \\
\hline EMP & Empréstimo \\
\hline EO & Equivalência operacional \\
\hline ER & Erro \\
\hline EX & Explicitação \\
\hline I & Implicitação \\
\hline $\mathrm{L}$ & Tradução Literal \\
\hline $\mathrm{M}$ & Modulação \\
\hline ME & Modulação através de especificação \\
\hline MG & Modulação através de generalização \\
\hline MP & $\begin{array}{c}\text { Modulação através de substituição de um } \\
\text { todo por uma parte }\end{array}$ \\
\hline MT & $\begin{array}{l}\text { Modulação através de substituição de } \\
\text { uma parte pelo todo }\end{array}$ \\
\hline $\mathrm{O}$ & Omissão \\
\hline $\mathrm{T}$ & Transcrição \\
\hline
\end{tabular}

Tabela 4.7 - Códigos utilizados para as modalidades

Os marcadores referenciais são analisados no capítulo 5 e os lingüísticos no capítulo 6 .

\subsubsection{Análise de graus de aproximação}

Cada solução tradutória (exemplo) será classificada como grau 1 a 5 de aproximação. Esta classificação é apresentada na tabela de resumo dos exemplos no apêndice. No final de cada seção dos capítulos 5 e 6 , uma tabela fornecerá informações sobre o número de cada tipo de modalidade que se encaixou em cada grau de aproximação. 


\subsubsection{Análise de variáveis secundárias}

As soluções serão analisadas também a respeito das variáveis secundárias identificadas na seção 4.4. Para cada arquivo, temos os seguintes dados:

- o tradutor (identificado por uma letra)

- a língua de domínio mais ativo do tradutor

- o sentido da tradução (para inglês ou para português)

- $\quad$ se a tradução foi juramentada ou não

- a situação tradutória

E para cada exemplo, temos os seguintes dados adicionais:

- $\quad \mathrm{a}(\mathrm{s})$ modalidade(s)

- o tipo de marcador, e o sub-tipo (jurídico, financeiro, etc.)

- $\quad$ o grau de aproximação.

Procura-se tendências baseadas nessas características, mas devido à pouca representação de algumas, nem sempre será possível perceber uma diferença marcante.

\subsubsection{Análise quantitativa}

Como toda unidade de estudo pode representar uma combinação sem restrições de modalidades, depois de terminar a análise qualitativa procurei um número limitado de categorias de modalidades e combinações de modalidades para facilitar a análise quantitativa. Estas 25 categorias são:

$\mathrm{C}$ - apenas correção

$\mathrm{D}$ - apenas decalque

EC - apenas equivalência cultural

EDV - apenas equivalência discursiva

$\mathrm{EF}$ - apenas equivalência funcional

EO - apenas equivalência operacional

ER - apenas erro

ER-L - erro + tradução literal 
EX-L - explicitação + tradução literal

I - apenas implicitação

L - apenas tradução literal

L-T - tradução literal + transcrição

M - apenas modulação

ME - apenas modulação através de especificação

MG - apenas modulação através de generalização

MP - apenas modulação através de substituição de um todo por uma parte

MT - apenas modulação através de substituição de uma parte pelo todo

O - apenas omissão

$\mathrm{T}$ - apenas transcrição

EMP - apenas empréstimo

EMP-L - empréstimo + tradução literal

EMP-EX-L - empréstimo + explicitação + tradução literal

$\mathrm{EMP}+\mathrm{EX} \pm$ outro - empréstimo + explicitação (ou estes dois mais um outro que não seja tradução literal)

EMP+outro - empréstimo + uma modalidade não inclusa nas outras categorias junto com empréstimo

outro - outra combinação de categorias (p.ex. D-L) 


\section{Análise qualitativa e quantitativa da tradução de marcadores referenciais}

Este capítulo analisa a tradução de marcadores referenciais, ou seja, marcadores extralingüísticos. A questão principal é até que ponto a tradução precisa mostrar sua alteridade para o receptor esperado.

Os marcadores dividem-se em 5 categorias: tipos de sociedades, nomes de documentos constitutivos, conceitos jurídicos, conceitos financeiros e qualificações de pessoas físicas e jurídicas.

\subsection{Tipos de sociedades e outras pessoas jurídicas}

Um marcador referencial importante nos corpora deste estudo é tipo de sociedade. Como os possíveis tipos e a organização de sociedades dependem da legislação de cada país, são bem diferentes no caso de países sem a mesma raiz jurídica, e podem, ainda, apresentar diferenças mesmo entre países com a mesma raíz jurídica, a busca para equivalência na tradução torna-se uma operação complexa.

Os tipos de sociedade e sua organização no Brasil, nos EUA e na Grã-Bretanha foram apresentados em seção 2.3, seguidos por uma lista de possíveis equivalências operacionais. Podemos utilizar as descrições daquela seção para melhor analisar as traduções nos corpora.

\subsubsection{Equivalências operacionais}

A maioria das sociedades encontradas nos corpora foi corporations ou limited liability companies nos Estados Unidos e sociedades anônimas ou sociedades limitadas no Brasil. Vimos na seção 2.3 que a sociedade anônima e a sociedade limitada têm uma correspondência forte no universo jurídico norte-americano com a corporation e a limited liability company, e vice-versa. Com esta forte correspondência, esperaríamos encontrar muitas equivalências operacionais. 


\begin{tabular}{|l|l|l|}
\hline Arquivo & Original & Tradução \\
\hline co51_br-usD, & sociedade anônima & corporation $^{\mathrm{EO}}$ \\
dc52_br-usD (2), & & \\
dc54_br-usnE & & \\
dc53_br-usnE & & \\
\hline
\end{tabular}

A tradução de sociedade anônima por corporation foi uma equivalência operacional.

\begin{tabular}{|l|l|l|}
\hline Arquivo & Original & Tradução \\
\hline $\begin{array}{l}\text { dc51_br-usL, } \\
\text { dc54_br-usnE } \\
(6)\end{array}$ & $\begin{array}{l}\text { sociedade por quotas de } \\
\text { responsabilidade limitada }\end{array}$ & limited liability company $^{\mathrm{EO}}$ \\
\hline $\begin{array}{l}\text { dc52_br-usD } \\
(5)\end{array}$ & sociedade limitada & limited liability company $^{\mathrm{EO}}$ \\
\hline
\end{tabular}

A "sociedade por quotas de responsabilidade limitada" é a designação antiga do atual "sociedade limitada", e é indicativa da idade do documento (pré-código civil de 2002). A tradução desse tipo de sociedade por limited liability company também é uma equivalência operacional, baseada na descrição dos dois tipos de sociedade na seção 2.3.

\begin{tabular}{|l|l|l|}
\hline Arquivo & Original & Tradução \\
\hline dc52_br-usD & sociedade limitada brasileira & limited liability company $^{\mathrm{EO}-\mathrm{O}}$ \\
\hline dc52_br-usD & sociedade limitada brasileira & Brazilian limited liability company $^{\mathrm{L}-\mathrm{EO}}$ \\
\hline
\end{tabular}

Nestes dois exemplos do mesmo documento, o tradutor não foi consistente. Em um caso o modificador "brasileira" foi omitido e no outro caso foi traduzido literalmente. Este documento é um caso especial, pois apesar de ser um contrato social de uma sociedade brasileira, vários fatores indicam que o documento é uma tradução para o português de um documento originalmente escrito em inglês. Veja a seção 4.4 para mais detalhes. 


\begin{tabular}{|l|l|l|}
\hline Arquivo & Original & Tradução \\
\hline dc52_br-usD & sociedade empresária limitada & limited liability company \\
\hline $\begin{array}{l}\text { dc54_obr-usnE } \\
(2)\end{array}$ & sociedade limitada empresária & limited liability company \\
\hline
\end{tabular}

No primeiro exemplo, do mesmo documento, é o autor que não foi consistente. $\mathrm{O}$ tradutor pode ter ajustado a tradução (omitindo a palavra empresária) para aquilo que supôs que o escritor pretendia ter escrito, pode ter tentado padronizar o termo para ser igual às muitas ocorrências de sociedade limitada no mesmo documento, ou simplesmente não notou a inconsistência do autor. $\mathrm{Na}$ verdade, é possível uma sociedade limitada ser ou empresária ou civil (veja a seção 2.3), portanto não foi necessariamente um erro do escritor. O fato de a sociedade ser empresária foi omitido na tradução, enquanto o restante do termo vem traduzido com uma equivalência operacional.

\begin{tabular}{|l|l|l|}
\hline Arquivo & Original & Tradução \\
\hline pr53_br-usnM & $\begin{array}{l}\text { sociedade por quotas de } \\
\text { responsabilidade limitada }\end{array}$ & $\begin{array}{l}\text { Brazilian }^{\mathrm{EX}} \underline{\text { limited liability company }} \\
\text { [sociedade por quotas de responsabilidade } \\
\text { limitada }^{\mathrm{EMP}}\end{array}$ \\
\hline
\end{tabular}

Neste documento, o tradutor utilizou explicitação de sentido, uma equivalência operacional e um empréstimo simultaneamente para traduzir a mesma unidade. Esta abordagem pode ter sido utilizada para tentar diminuir o risco da tradução não ser entendida plenamente pelo leitor previsto. Porém, o mais provável, dado que é uma procuração no estilo brasileiro, é que já era prevista a tradução do documento de volta ao português brasileiro para uso dentro do universo jurídico do Brasil. 


\subsubsection{Modulaç̃̃es}

\begin{tabular}{|l|l|l|}
\hline Arquivo & Original & Tradução \\
\hline $\begin{array}{l}\text { co53_br-usnF, } \\
\text { dc53_br-usN }\end{array}$ & pessoa jurídica & legal entity $^{\mathrm{M}}$ \\
\hline
\end{tabular}

Neste exemplo, foi utilizada uma modulação, e o termo utilizado na tradução é o termo geralmente empregado em inglês norte-americano.

\begin{tabular}{|l|l|l|}
\hline Arquivo & Original & Tradução \\
\hline dc54_br-usnE & $\begin{array}{l}\text { geridos por administradores, } \\
\text { pessoas naturais residentes no } \\
\text { país }\end{array}$ & $\begin{array}{l}\text { managed by administrators who shall be } \\
\text { resident in the country < omissão }>\end{array}$ \\
\hline
\end{tabular}

Este é um raro caso de omissão, mas no contexto não há prejuízo para o sentido, pois pessoas jurídicas não podem ser residentes de um país.

\begin{tabular}{|c|c|c|}
\hline Arquivo & Original & Tradução \\
\hline $\begin{array}{l}\text { pr3_us- } \\
\text { brB }\end{array}$ & $\begin{array}{l}\text { a corporation organized and existing } \\
\text { in accordance with the laws of }\end{array}$ & $\begin{array}{l}\text { sociedade }^{\text {MG }} \text { constituída e existente de } \\
\text { acordo com as leis de }\end{array}$ \\
\hline $\begin{array}{l}\text { co3_us- } \\
\text { brG }\end{array}$ & $\begin{array}{l}\text { a corporation duly organized and } \\
\text { validly existing under the laws of } \\
\text { Country1, }\end{array}$ & $\begin{array}{l}\text { sociedade }^{\text {MG }} \text { devidamente constituída e } \\
\text { com existência válida conforme as leis de } \\
\text { Countryl }\end{array}$ \\
\hline $\begin{array}{l}\text { col1_us- } \\
\text { brN }\end{array}$ & $\begin{array}{l}\text { between companyl, a corporation } \\
\text { organized under the laws... }\end{array}$ & $\begin{array}{l}\text { entre a Company1, uma sociedade } \\
\text { constituída segundo a legislação... }\end{array}$ \\
\hline
\end{tabular}

Nestes três exemplos, um tipo de sociedade, a corporation, foi traduzido pela supercategoria sociedade, uma modulação através de generalização. A importância dessa perda de informação através da generalização depende de quem contratou a tradução. Se for encomendada pela própria corporation, esta certamente sabe qual tipo de sociedade é. Porém, 
se a tradução foi feita para a outra parte ou para um terceiro, geralmente é importante saber qual o tipo de sociedade por causa das diferenças de responsabilidade por parte dos sócios.

Na procuração pr3, essa informação pode ser considerada importante, pois, no contexto, o mandato é entre uma corporation norte-americana e um representante no Brasil, e a procuração diz especificamente que o mandante não atua como pessoa física, mas como Secretária da corporation. O fato de que é corporation (e não Partnership, por exemplo) não é mencionado novamente no documento. Na nota promissória co3, o fato da sociedade ser uma corporation é importante, pois o banco que emprestou o dinheiro à sociedade não pode procurar os acionistas da empresa para sanar qualquer dívida não paga. No contrato co11, um Software License Agreement, a corporation é a empresa fornecedora de software. A situação é semelhante à do documento co3, pois o tipo de sociedade é mencionado somente uma vez e pode ser importante em um momento futuro se houver uma questão sobre responsabilidade por perdas e danos.

\begin{tabular}{|l|l|l|}
\hline Arquivo & Original & Tradução \\
\hline dc3_uk- & $\begin{array}{l}\text { it holds shares, debt obligations } \\
\text { brE }\end{array}$ & $\begin{array}{l}\text { detiver ações, obrigações de débito ou outros } \\
\text { or other securities in a company } \\
\text { incorporated under the } \\
\text { valores mobiliários em uma sociedade }\end{array}$ \\
& $\begin{array}{l}\text { International Business }_{\text {comercial }^{\text {MP }}} \text { constituída de conformidade com a } \\
\text { Lei de Sociedades Comerciais Internacionais ... }\end{array}$ \\
\hline
\end{tabular}

Neste exemplo temos o mesmo termo visto acima, com company traduzido por uma expressão que representa uma subcategoria no sistema brasileiro. A tradução é mais restrita do que o original.

\begin{tabular}{|l|l|l|}
\hline Arquivo & Original & Tradução \\
\hline $\begin{array}{l}\text { dc54_br- } \\
\text { usnE }\end{array}$ & sociedades simples & non-enterpreneurial companies ${ }^{\mathrm{M}}$ \\
\hline
\end{tabular}


Esta solução é uma modulação. Como visto na seção 2.3, não existe um equivalente operacional para a sociedade simples. Como todas as sociedades brasileiras são classificadas como empresárias ou simples (os não empresárias), a solução acima deve ser baseada nessa definição, com empresária traduzida como entrepreneur.

\subsubsection{Traduções literais e equivalências funcionais}

\begin{tabular}{|c|c|c|}
\hline Arquivo & Original & Tradução \\
\hline $\begin{array}{l}\text { pr8_ukn- } \\
\text { brH }\end{array}$ & $\begin{array}{l}\text { Company1, a company incorporated } \\
\text { under the laws of }\end{array}$ & $\begin{array}{l}\text { Companhia1, } \underline{\text { sociedade }}^{\mathrm{L}} \text { constituída nos } \\
\text { termos da Lei da }\end{array}$ \\
\hline $\begin{array}{l}\text { dc2 } 2 \text { uk- } \\
\text { brB }\end{array}$ & $\begin{array}{l}\text { as a company incorporated under the } \\
\text { laws of a jurisdiction outside } \\
\text { Territory1 in the manner provided } \\
\text { under those laws. }\end{array}$ & $\begin{array}{l}\text { como sociedade }^{\mathrm{L}} \text { constituída sob as leis de } \\
\text { uma jurisdição fora das Território1, na } \\
\text { forma prevista por essas leis. }\end{array}$ \\
\hline $\begin{array}{l}\text { dc3_uk- } \\
\text { brE }\end{array}$ & $\begin{array}{l}\text { any company incorporated under the } \\
\text { International Business Companies ... }\end{array}$ & \begin{tabular}{l}
\multicolumn{4}{l}{ qualquer sociedade $^{\mathrm{L}}$ constituída conforme } \\
a Lei de Sociedades Comerciais \\
Internacionais ...
\end{tabular} \\
\hline
\end{tabular}

Nestes três exemplos os tradutores traduzam a palavra company, que é uma palavra geral em muitos contextos, pela palavra sociedade, igualmente geral. Nesses três casos, não é necessário ser mais específico porque o tipo exato de sociedade é especificado no trecho logo em seguida.

\begin{tabular}{|l|l|l|}
\hline Arquivo & Original & Tradução \\
\hline $\begin{array}{l}\text { dc54_br- } \\
\text { usnE }\end{array}$ & $\begin{array}{l}\text { participação em outras sociedades } \\
\text { comerciais ou civis, como sócia, }\end{array}$ & $\begin{array}{l}\text { hold interests in other } \text { commercial }^{\mathrm{L}} \text { or } \\
\text { civil companies }^{\mathrm{L}} \text { as partner, }\end{array}$ \\
\hline
\end{tabular}

Esta tradução é puramente literal. A divisão no Brasil antigamente era entre sociedades civis e comerciais, uma divisão que não existe na lei norte-americana. 


\begin{tabular}{|l|l|l|}
\hline Arquivo & Original & Tradução \\
\hline $\begin{array}{l}\text { dc1_us- } \\
\text { brE }\end{array}$ & $\begin{array}{l}\text { This corporation is a close } \\
\text { corporation. }\end{array}$ & $\begin{array}{l}\text { Esta Sociedade é uma sociedade de capital } \\
\text { fechado }^{\mathbf{E F}} .\end{array}$ \\
\hline
\end{tabular}

Este exemplo é especial, pois a close corporation existe só em alguns estados. O seguinte trecho descreve a close corporation no estado de Vermont:

A Close corporation is a Vermont corporation that is either an $\mathrm{S}$ or $\mathrm{C}$ corporation for federal tax purposes that, provided certain conditions are met, dispenses with the formality of having decisions approved by both shareholders and corporate directors. ... In a Close corporation, all management decisions are made by the shareholders (providing there will be no more than 35 shareholders and none of the corporation's shares will be publicly traded) because they are typically the people who are in charge of running the business.

Governance of a close corporation differs from that of a general corporation in several ways. For example, as a close corporation, corporate bylaws are not required if the information otherwise required by law to be contained in bylaws is already contained either in the Articles of Incorporation or in an authorized shareholder agreement. Close corporations are not required to have an annual meeting unless one is requested in writing by one or more shareholders. Perhaps the most significant feature of a close corporation is that the corporation may choose to operate through a shareholder agreement. Shareholder agreements allow the corporation to eliminate the board of directors, restrict the discretion or powers of the board, or create a relationship among the shareholders or between the shareholders and the corporation that would otherwise be appropriate only among partners in a partnership. (State of Vermont, 2006) [destaque meu]

Esta solução é difícil de classificar. Trata-se claramente de uma equivalência funcional parcial, pois descreve uma das características da sociedade segundo a legislação do estado de origem - $\mathrm{o}$ fato da sociedade ter capital fechado. Porém, a característica descrita não é única a 
este tipo de empresa, nem é necessariamente sua característica mais importante. Todas as sociedades analisadas na seção 2.3 menos a Regular Corporation têm capital fechado. Segundo o texto acima, publicado pelo Estado de Vermont, uma diferença importante é que o close corporation pode se reger por um contrato entre os acionistas. Uma outra equivalência funcional que inclui este dado poderia descrever melhor este tipo de empresa para o leitor brasileiro, algo como "sociedade regida por contrato entre os acionistas".

\subsubsection{Listas de tipos de entidades}

Listas de tipos de entidades são mais desafiadoras para o tradutor. Em arquivo co2, o tradutor usou a seguinte solução:

\begin{tabular}{|l|l|l|}
\hline Arquivo & Original & Tradução \\
\hline $\begin{array}{l}\text { co2_us- } \\
\text { brG }\end{array}$ & $\begin{array}{l}\text { if a corporation, partnership or } \\
\text { other organization, }\end{array}$ & $\begin{array}{l}\text { caso seja uma } \text { sociedade anônima }^{\mathrm{EO}}, \\
\text { sociedade }^{\mathrm{MG}} \text { ou outra pessoa jurídica }\end{array}$
\end{tabular}

Vimos na figura 2.7 da seção 2.3 que o partnership é só um tipo de sociedade, e certamente não inclui todos os tipos de sociedades (não inclui o sole proprietorship e a Limited Liability Company, entre outras). Portanto pode-se dizer que a tradução de partnership foi uma modulação através de generalização, na qual uma subcategoria é traduzida pela categoria que a inclui. A tradução de corporation foi uma equivalência operacional e a tradução de organization foi uma modulação (pois organização seria a tradução literal).

\begin{tabular}{|l|l|l|}
\hline Arquivo & Original & Tradução \\
\hline $\begin{array}{l}\text { co2_us- } \\
\text { brG }\end{array}$ & $\begin{array}{l}\text { of any person, corporation or } \\
\text { other entity }\end{array}$ & $\begin{array}{l}\text { de qualquer pessoa } \\
\text { entidade }\end{array}$ \\
\hline
\end{tabular}

No mesmo arquivo, o tradutor novamente traduziu um tipo de sociedade pela palavra sociedade, uma modulação através de generalização. As outras duas traduções são literais. 


\begin{tabular}{|l|l|l|}
\hline Arquivo & Original & Tradução \\
\hline $\begin{array}{l}\text { pr4_ukn- } \\
\text { brM }\end{array}$ & any such company or corporation & qualquer referida sociedade $^{\text {MG-I }}$ \\
\hline
\end{tabular}

Nesta procuração da Grã-Bretanha, temos novamente uma modulação em que o binômio de dois tipos de sociedade vem traduzido pela palavra sociedade representante da supercategoria—qualquer tipo de sociedade.

\begin{tabular}{|c|c|c|}
\hline Arquivo & Original & Tradução \\
\hline $\begin{array}{l}\text { dc4_uk- } \\
\text { brE }\end{array}$ & $\begin{array}{l}\text { another company or a partnership, } \\
\text { joint venture, trust or other enterprise }\end{array}$ & $\begin{array}{l}\text { de outra } \underline{\text { empresa }}^{\mathrm{L}} \text { ou parceria }{ }^{\mathrm{L}} \text {, } \\
\underline{\underline{\text { empreendimento conjunto }}}^{\mathrm{L}} \text {, fidúcia }{ }^{\mathrm{L}} \text { ou } \\
\text { outro empreendimento }^{\mathrm{L}}\end{array}$ \\
\hline $\begin{array}{l}\text { dc4_uk- } \\
\text { brE }\end{array}$ & $\begin{array}{l}\text { An individual, a corporation, a trust, } \\
\text { the estate of a deceased individual, a } \\
\text { partnership or an unincorporated } \\
\text { association of persons. }\end{array}$ & $\begin{array}{l}{\underline{\text { Indivíduo }^{\mathrm{L}}}} \text {, pessoa jurídica } \\
\text { espólio de }^{\mathrm{MG}}, \text { fidúcia }^{\mathrm{L}} \text {, } \\
\text { parceria }^{\mathrm{L}} \text { ou uma } \underline{\text { associação não falecido }}^{\mathrm{L}} \text {, uma } \\
\text { constituída de pessoas }^{\mathrm{L}} \text {. }\end{array}$ \\
\hline
\end{tabular}

Neste contrato, parece que o autor queria incluir qualquer entidade jurídica, e fez uma lista de entidades mutualmente excludentes. A tradução de todos os termos em dc4 foi principalmente literal, com o uso, em geral, de termos não jurídicos ou não específicos ao ramo. Joint venture, por exemplo, é normalmente traduzido por joint venture mesmo em português, um empréstimo já consagrado. Partnership em inglês é um tipo de sociedade, mas parceria não o é em português. E a tradução de individual para o português é, normalmente, pessoa física. A tradução de corporation como pessoa jurídica é mais um caso de uma modulação através de generalização.

\begin{tabular}{|l|l|l|}
\hline Arquivo & Original & Tradução \\
\hline $\begin{array}{l}\text { dc2_uk- } \\
\text { brB }\end{array}$ & $\begin{array}{l}\text { any private, public or semi-public } \\
\text { corporation or juridical person }\end{array}$ & $\begin{array}{l}\text { de qualquer empresa } \\
\text { estatal }^{\mathrm{M}} \text { ou } \text { privada }^{\mathrm{L}} \text {, economia } \\
\text { mista }^{\mathrm{M}} \text { ou }\end{array}$ \\
\hline
\end{tabular}




\begin{tabular}{|c|c|c|}
\hline & & pessoa jurídica $^{\mathrm{L}}$ \\
\hline $\begin{array}{l}\text { dc2_uk- } \\
\text { brB }\end{array}$ & any corporation or juridical persons & $\begin{array}{llll}\text { qualquer } & \text { sociedade }^{\mathrm{MG}} \text { ou } & \text { pessoa } \\
\text { jurídica }^{\mathrm{L}} & & & \end{array}$ \\
\hline $\begin{array}{l}\text { dc2_uk- } \\
\text { brB }\end{array}$ & $\begin{array}{l}\text { another company or a partnership, } \\
\text { joint venture, trust or other enterprise. }\end{array}$ & $\begin{array}{l}\text { outra } \text { sociedade }^{\mathrm{L}}, \text { sociedade em } \\
\text { comandita ou em nome coletivo }{ }^{\mathrm{EO}} \text { “joint } \\
\text { venture" }^{\text {EMP }} \text {, sociedade de negócios } \\
\text { fiduciários }^{\mathrm{EF}} \text { [“trust"] }{ }^{\mathrm{EMP}} \text { ou outra } \\
\text { empresa }^{\mathrm{M}}\end{array}$ \\
\hline
\end{tabular}

As traduções em dc2, ao contrário das de dc4, são uma combinação de muitas modalidades diferentes, com poucas traduções literais. Aqui temos novamente uma modulação onde um tipo de sociedade (corporation) é traduzido como se fosse qualquer tipo de sociedade. O primeiro adjetivo é uma tradução literal com transposição obrigatória. A tradução de public (como parte da expressão public corporation) como estatal é uma modulação pouco recomendável. Estatal é um termo menos exato, menos jurídico. O equivalente operacional de um public corporation seria a pessoa jurídica de direito público. Segundo Houaiss (2001), uma empresa estatal é "uma pessoa jurídica de direito privado, de natureza mercantil, com capital misto e controle do Estado". Porém, o próprio Houaiss menciona que "no Brasil é freqüente o uso do termo estatal para se referir tanto à empresa de economia mista quanto à empresa pública". Segundo a primeira definição mais exata, a tradução de public corporation por estatal é um erro, e segundo a segunda definição a tradução para estatal serviria para englobar public ou semi-public corporation, sem precisar do termo "economia mista" na tradução.

A expressão juridical person não é comum nem nos EUA nem no Reino Unido (onde se usa juristic person), mas existe no universo discursivo do inglês internacional. Por exemplo, no tratado Inter-American Convention on Personality and Capacity of Juridical Persons in Private International Law, Juridical Persons é definido da mesma maneira que pessoa jurídica no Brasil: "juridical person being understood to mean any entity having its own existence and being responsible for its own actions, separately and distinctly from those of its members or 
organizers, and classified as a juridical person in accordance with the law of the place of its organization". (Organization of American States, 2006)

Como vimos na seção 2.3, o partnership (um tipo de sociedade nos EUA e no Reino Unido) corresponde parcialmente, da maneira apresentada na referida seção, à sociedade em nome coletivo e à sociedade em comandita por ações e a algumas outras sociedades brasileiras. A tradução de enterprise por empresa é uma modulação, pois a tradução literal teria sido empreendimento.

\begin{tabular}{|c|c|c|}
\hline Arquivo & Original & Tradução \\
\hline $\begin{array}{l}\text { dc54_br- } \\
\text { usnE }\end{array}$ & $\begin{array}{l}\text { bem como autarquias, sociedades de } \\
\text { economia mista e entidades } \\
\text { paraestatais, seja na esfera federal, } \\
\text { estadual ou municipal }\end{array}$ & $\begin{array}{l}\text { as well as agencies }^{\mathrm{MG}} \text { and mixed capital } \\
\text { and parastate }{ }^{\mathrm{D}-\mathrm{M}} \text { companies, be it on a } \\
\text { federal, state or municipal level. }\end{array}$ \\
\hline
\end{tabular}

Uma autarquia, no direito brasileiro, é:

AUTARQUIA. 1. Direito econômico. ...

2. Direito administrativo. Pessoa jurídica de direito público interno, de administração indireta, criada por lei, com capacidade administrativa, fiscalizada e tutelada diretamente pelo Estado. Executa certas atividades e serviços típicos de natureza administrativa e possui patrimônio e receita próprios. Por exemplo, INCRA, CADE, INSS e USP. Seus funcionários são servidores autárquicos, equiparados aos funcionários públicos para certos efeitos. (Diniz, 2005, v. 1, p. 411)

Portanto, o termo é mais específico do que o termo agency, que serviria como tradução de órgão. O binômio "sociedades de economia mista e entidades paraestatais" foi traduzido com uma tradução literal seguida por um decalque com uma modulação ("entidade" traduzida como company). 


\begin{tabular}{|l|l|lll|}
\hline Arquivo & Original & Tradução & & \\
\hline $\begin{array}{l}\text { dc3_uk- } \\
\text { brE }\end{array}$ & of any company or corporation & $\begin{array}{l}\text { qualquer sociedade } \\
\text { anônima }^{\text {EO }}\end{array}$ & & \\
\hline
\end{tabular}

Como visto acima, a tradução de corporation por sociedade anônima é uma equivalência operacional. Antes do novo código civil, em vez de classificar toda empresa como sociedade empresária ou sociedade simples, elas eram classificadas como sociedades comerciais ou sociedades civis. Na figura 2.6 da seção 2.3, vemos que a sociedade anônima é um tipo de sociedade, e sociedade comercial é uma classificação que engloba vários tipos de sociedade. A sociedade anônima corresponde, operacionalmente, à corporation, mas o termo sociedade comercial não engloba todos os possíveis tipos de sociedade restantes. No sistema britânico, como explicado na seção 2.3 (veja a figura 2.8), company é utilizado como uma forma de sociedade, comparado com a corporation, partnership e sole trader, e é também utilizado como a denominação para uma categoria de pessoa jurídica personificada que também inclui a corporation. Independentemente da interpretação, o termo sociedade comercial é, ao mesmo tempo, mais abrangente e mais restritivo (pois não inclui sociedades civis). Esta tradução provavelmente foi o resultado de um desentendimento do significado jurídico do termo utilizado em português.

\begin{tabular}{|l|l|l|}
\hline Arquivo & Original & Tradução \\
\hline $\begin{array}{l}\text { co50_br- } \\
\text { usL }\end{array}$ & pessoa jurídica ou entidade & business entity $^{\mathrm{EF}}$ or legal entity \\
\hline
\end{tabular}

Aqui temos um binômio, onde os dois termos são basicamente sinônimos. A primeira parte (pessoa jurídica) foi traduzida utilizando uma equivalência funcional (não existe uma tradução literal no inglês norte-americano) e a tradução mais consagrada seria legal entity, que foi utilizada para traduzir a segunda parte, por ser uma tradução literal, com transposição obrigatória. 


\begin{tabular}{|l|l|l|}
\hline Arquivo & Original & Tradução \\
\hline $\begin{array}{l}\text { dc52_br- } \\
\text { usD }\end{array}$ & pessoa física ou jurídica & individual $^{\mathrm{L}}$ or entity \\
\hline $\begin{array}{l}\text { co59_br- } \\
\text { usL }\end{array}$ & pessoa física ou jurídica & individual $^{\mathrm{L}}$ or business $^{\mathrm{M}}$ \\
\hline
\end{tabular}

Nesses dois documentos, as mesmas quatro palavras no original foram traduzidas de maneira diferente para o inglês. Nos dois casos o primeiro termo, "pessoa física", foi traduzido através de uma transposição. O segundo termo foi traduzido através de duas modulações diferentes, entity e business. Nos dois casos houve um abaixamento de registro do registro jurídico para o registro comum, pois o termo mais jurídico teria sido legal entity.

\subsubsection{Resumo de freqüência de ocorrência e conclusões}

Em resumo, a figura 5.1 mostra a freqüência de ocorrência de soluções representando cada grau de ocorrência (veja o apêndice para os dados brutos completos) para os exemplos da seção 5.1 .

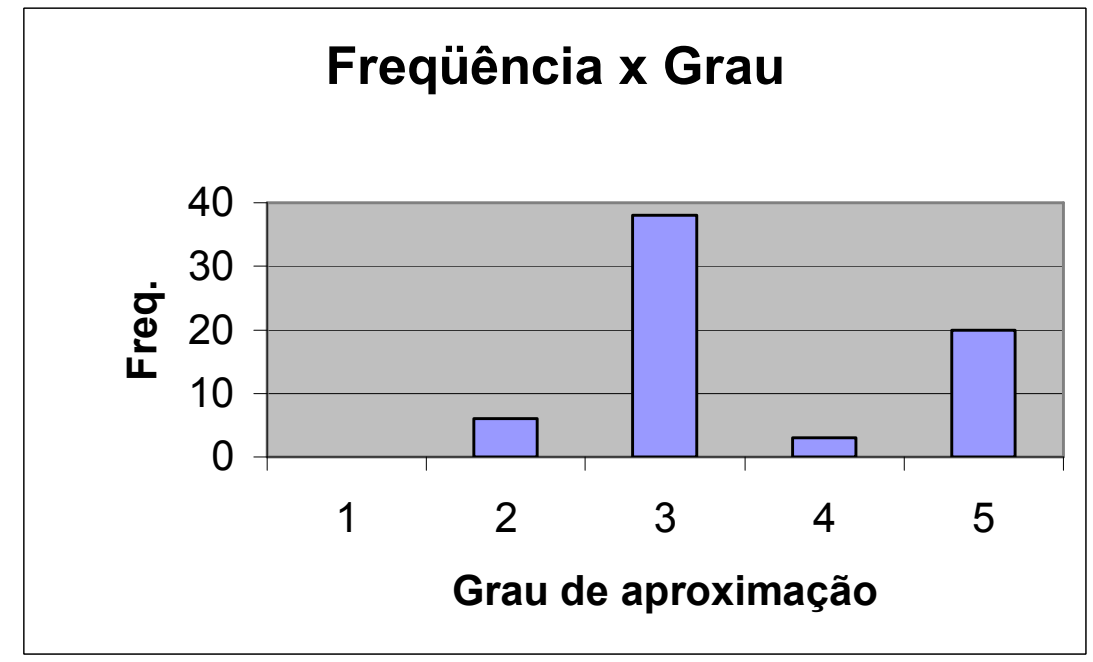

Figura 5.1 - Freqüência de ocorrência de cada grau de aproximação - tipos de sociedades 
A maioria dos resultados se encaixou no $3^{\circ}$ e no $5^{\circ}$ graus de aproximação. Observe a quase ausência de resultados representativos do $4^{\circ}$ grau. A tabela 5.1 mostra as modalidades correspondentes a cada grau de aproximação e o número de ocorrências de cada modalidade. O agrupamento de múltiplas modalidades em categorias é definido na seção 4.5.5.

\begin{tabular}{|c|c|c|c|c|c|}
\hline Modalidade & Grau 1 & Grau 2 & Grau 3 & Grau 4 & Grau 5 \\
\hline $\mathrm{EF}$ & - & - & 2 & - & - \\
\hline EMP & - & - & 1 & - & - \\
\hline $\mathrm{EO}$ & - & - & - & - & 10 \\
\hline$I$ & - & - & 1 & - & - \\
\hline $\mathrm{L}$ & - & 4 & 20 & - & - \\
\hline $\mathrm{M}$ & - & 1 & 5 & - & 2 \\
\hline $\mathrm{MG}$ & - & - & 8 & - & 2 \\
\hline MP & - & - & - & - & 2 \\
\hline $\mathrm{O}$ & - & - & 1 & - & - \\
\hline $\begin{array}{l}\text { EMP+EX } \\
\pm \text { outro }\end{array}$ & - & - & - & 1 EMP-EO-EX & - \\
\hline outro & - & $1 \mathrm{D}-\mathrm{M}$ & - & $\begin{array}{c}1 \text { EO-L } \\
1 \text { EF-EMP }\end{array}$ & $\begin{array}{c}3 \mathrm{EO}-\mathrm{O} \\
1 \mathrm{M}-\mathrm{MG}\end{array}$ \\
\hline totais & $\mathbf{0}$ & 6 & 38 & 3 & 20 \\
\hline
\end{tabular}

Tabela 5.1 - Freqüência de ocorrência de modalidade por grau de aproximação — tipos de sociedades

Observe a quase ausência de empréstimo e a presença significativa de tradução literal—quase o dobro da presença de equivalência operacional. Houve 24 ocorrências de tradução literal pura e 10 ocorrências de equivalência operacional pura mais 5 ocorrências de equivalência operacional junto com outra modalidade. 
Esta ausência de marcas de alteridade nas traduções mostra o nível de aceitação destes tipos de tradução (neutro ou localização) e a procura de equivalências operacionais e não funcionais (houve apenas 3 ocorrências de equivalência funcional, um junto com empréstimo). Šarčević (1997) já escreveu sobre justamente este assunto:

"Por exemplo, atrás chegamos à conclusão de que a sociedade por quotas portuguesa desempenha a mesma função que a private company limited by shares do direito inglês, pelo que são equivalentes. Ora, a afirmação de que ambas são equivalentes é verdadeira à luz do direito comparado, mas pode não servir para a tradução jurídica.

$\mathrm{Na}$ tradução jurídica, para determinar se existe equivalência entre conceitos, tem que existir uma total concordância entre os seus aspectos essenciais." (Šarčević, 1997, p. 238)

É claro que uma tradução correta segundo o direito comparado pode não servir dentro do contexto de um documento específico e sua tradução.

\subsection{Nomes de documentos constitutivos}

Os tipos de documentos constitutivos foram apresentados e descritos na seção 2.4. Vimos no final daquela seção que um documento no Brasil é equivalente (em termos operacionais) à soma de dois documentos, tanto nos EUA quanto na GB. Porém, é possível encontrar outros tipos de equivalências, que dependem do contexto. Veremos que os documentos constitutivos norte-americanos e britânicos são freqüentemente traduzidos pelo nome do único documento constitutivo brasileiro quando aparecem sozinhos, e por uma modulação e equivalência funcional quando aparecem juntos. 


\subsubsection{Documentos constitutivos dos EUA}

\begin{tabular}{|l|lr|l|}
\hline Arquivo & Original & Tradução \\
\hline co5_us-brJ & $\begin{array}{l}\text { represented herein as provided } \\
\text { for in its articles of } \\
\text { incorporation }\end{array}$ & $\begin{array}{l}\text { neste ato devidamente representada } \\
\text { conforme seus atos constitutivos }\end{array}$ \\
\hline $\begin{array}{l}\text { dc1_us- } \\
\text { brE (2) }\end{array}$ & $\begin{array}{l}\text { ARTICLES OF } \\
\text { INCORPORATION }\end{array}$ & of & \\
\hline
\end{tabular}

Nestes primeiros dois exemplos, os tradutores utilizaram uma equivalência funcional, talvez para evitar a questão da falta de equivalência operacional exata.

\begin{tabular}{|c|c|c|}
\hline Arquivo & Original & Tradução \\
\hline $\begin{array}{l}\text { pr8_ukn- } \\
\text { brH }\end{array}$ & $\begin{array}{l}\text { to exercise for and in the name } \\
\text { of the PRINCIPAL, upon prior } \\
\text { written authorization of the } \\
\text { PRINCIPAL by fax or letter, } \\
\text { the rights conferred by law, } \\
\text { articles of association by virtue } \\
\text { of or attached to the quotas held } \\
\text { by the PRINCIPAL } \\
\text { representing the corporate } \\
\text { capital of the company } \\
\text { indicated in item } 1 \text { above; }\end{array}$ & $\begin{array}{l}\text { exercer em favor da OUTORGANTE e em } \\
\text { seu nome, mediante autorização prévia por } \\
\text { escrito da OUTORGANTE através de fax } \\
\text { ou carta, os direitos conferidos por lei, por } \\
\frac{\text { contrato social }^{\mathrm{MT}}}{\mathrm{em} \text { virtude de ou relativos }} \\
\text { às quotas mantidas pela OUTORGANTE, } \\
\text { que representem o capital social da } \\
\text { sociedade indicada no item } 1 \text { supra; }\end{array}$ \\
\hline
\end{tabular}

Este exemplo é uma modulação e não uma equivalência operacional devido ao conteúdo dos articles of association não ser equivalente ao conteúdo do contrato social, como explicado na seção 2.4. Podemos classificar esta modulação como uma na qual uma parte é substituída pelo todo, dado que o contrato social seria equivalente (operacionalmente) ao memorandum of 
association mais os articles of association. Pode-se ver pelo contexto (em que somente os articles of association são mencionados, e portanto não há a preocupação de diferenciar estes do memorandum of association) que contrato social pode ser considerado uma solução aceitável, pois é neste documento que os direitos em questão seriam conferidos se fosse uma sociedade brasileira.

\begin{tabular}{|l|l|l|l|}
\hline Arquivo & Original & Tradução \\
\hline co2_us- & do not contravene or violate the & não contraria nem viola os atos \\
brG & Undersigned's charter or & constitutivos $^{\mathrm{EF}}$ do Signatário & \\
& bylaws & & \\
\end{tabular}

O termo charter é um sinônimo de articles of incorporation, portanto o binômio charter or bylaws (ou charter and bylaws) seria o equivalente operacional de estatuto social baseado no levantamento da seção 2.4. Porém, aqui o tradutor usou atos constitutivos, uma equivalência funcional já vista acima.

\begin{tabular}{|c|c|c|}
\hline Arquivo & Original & Tradução \\
\hline $\begin{array}{l}\text { dc1_us- } \\
\text { brE }\end{array}$ & $\begin{array}{l}\text { Unless otherwise set forth in } \\
\text { these Articles of Incorporation, } \\
\text { the number of directors that } \\
\text { shall constitute the whole Board } \\
\text { of Directors of the Corporation } \\
\text { shall be fixed by, or in the } \\
\text { manner specified in, the Bylaws } \\
\text { of the Corporation. }\end{array}$ & $\begin{array}{l}\text { Exceto se estipulado do contrário nestes } \\
\text { Atos Constitutivos, o número de diretores } \\
\text { que constituirão o Conselho de } \\
\text { Administração da Sociedade deverá ser } \\
\text { determinado pelo contrato social } \\
\text { Sociedade ou da maneira especificada } \\
\text { neste. }\end{array}$ \\
\hline
\end{tabular}

O termo Articles of Incorporation nessa frase já foi analisado acima. Foi traduzido com uma equivalência funcional. Este documento (dc1_us-brE) contém justamente os Articles of Incorporation da empresa em questão, e não é uma referência a eles em um contrato ou procuração. O problema aqui é como diferenciar os nomes dos dois documentos norte- 
americanos quando no sistema brasileiro só existe um. O equivalente operacional da corporation é a sociedade anônima, e a sociedade anônima tem um estatuto social e não um contrato social. Portanto, a tradução do termo bylaws por contrato social é meio como misturar laranjas e bananas. Como os bylaws não correspondem exatamente ao estatuto social (em termos operacionais) classifiquei esta solução como uma modulação em que uma parte vem traduzida por um termo que representa o todo.

\begin{tabular}{|l|l|l|}
\hline Arquivo & Original & Tradução \\
\hline $\begin{array}{l}\text { co5_us-brJ } \\
(3)\end{array}$ & $\begin{array}{l}\text { represented herein as provided } \\
\text { for in its bylaws }\end{array}$ & $\begin{array}{l}\text { neste ato devidamente representada } \\
\text { conforme seu Estatuto Social }\end{array}$ \\
\hline
\end{tabular}

Neste exemplo, um olhar mais cuidadoso ao contexto mostra que esta sentença se refere a uma sociedade anônima brasileira (o CNPJ e inscrição estadual aparecem logo em seguida). Temos aqui, portanto, uma situação em que estatuto social foi traduzido como bylaws por um tradutor desconhecido ou pelo próprio autor do documento, e depois traduzido de volta para estatuto social neste exemplo. Como a empresa em questão é uma sociedade anônima brasileira que não pode ter "bylaws", a solução tradutória é uma correção pelo uso do único termo correto dentro do contexto da lei brasileira.

\subsubsection{Documentos constitutivos na GB}

\begin{tabular}{|l|l|l|}
\hline Arquivo & Original & Tradução \\
\hline $\begin{array}{l}\text { dc4_uk- } \\
\text { brE (2) }\end{array}$ & These $\underline{\text { Articles of Association }}$ & Estes Estatutos Sociais $^{\text {ET }}$ \\
\hline
\end{tabular}

Nos exemplos acima, Articles of Association foi traduzido com a modulação em que uma parte é traduzida por um termo que representa o todo. O primeiro documento contém justamente os Articles of Association da empresa, portanto a diferenciação entre estes e o Memorandum of Association (documento dc3_uk-brE) seria importante. Nem contrato social nem estatuto social são plenamente equivalentes aos articles of association no sentido de equivalente operacional. 


\begin{tabular}{|l|l|l|}
\hline Arquivo & Original & Tradução \\
\hline $\begin{array}{l}\text { pr4_ukn- } \\
\text { brM }\end{array}$ & $\begin{array}{l}\text { in accordance with the Company's } \\
\text { Articles of Association }\end{array}$ & $\begin{array}{l}\text { nos termos do contrato social } \\
\text { Sociedade }\end{array}$ \\
\hline $\begin{array}{l}\text { pr4_ukn- } \\
\text { brM }\end{array}$ & $\begin{array}{l}\text { Amendment to the Articles of } \\
\text { Association }\end{array}$ & $\begin{array}{l}\text { Alteração Contratual } \\
\text { M-C }\end{array}$ \\
\hline
\end{tabular}

Neste exemplo, um olhar mais cuidadoso ao contexto mostra que esta sentença se refere a uma sociedade limitada brasileira. Temos aqui, portanto, uma situação em que "contrato social" foi traduzido como articles of association por um tradutor desconhecido ou pelo próprio autor do documento, e depois traduzido de volta para contrato social neste exemplo. Como a empresa em questão é uma sociedade limitada brasileira que não pode ter "articles of association", a solução tradutória é uma correção pelo uso do único termo correto dentro do contexto da lei brasileira. O segundo exemplo, no mesmo documento, é uma modulação consistente com a correção já analisada, e portanto também uma correção.

\begin{tabular}{|c|c|c|}
\hline Arquivo & Original & Tradução \\
\hline $\begin{array}{l}\text { pr4_ukn- } \\
\text { brM (3) }\end{array}$ & $\begin{array}{l}\text { To represent the Grantor as a } \\
\text { quotaholder or shareholder of the } \\
\text { Brazilian company XXX Ltda., } \\
\text { as well as any other company in } \\
\text { which the Grantor may hold } \\
\text { equity in Brazil, and to subscribe } \\
\text { for quotas and to pay therefore, } \\
\text { either fully or in part, by cash or } \\
\text { transfer of assets and rights, and } \\
\text { to sign for and in the name of the } \\
\text { Grantor all public and private } \\
\text { deeds, Articles of Association... }\end{array}$ & $\begin{array}{l}\text { Representar a Outorgante como acionista ou } \\
\text { sócio da sociedade brasileira XXX Ltda., bem } \\
\text { como em qualquer outra sociedade de cujo } \\
\text { capital a Outorgante possa participar no } \\
\text { Brasil, e subscrever cotas e integralizá-las, } \\
\text { total ou parcialmente, em dinheiro ou } \\
\text { mediante conferência de bens e direitos, e } \\
\text { assinar em nome e lugar da Outorgante todos } \\
\text { e quaisquer instrumentos públicos e } \\
\text { particulares, estatutos e contratos sociais }{ }^{\mathrm{EX}-} \\
\underline{\mathrm{C}}, \ldots\end{array}$ \\
\hline
\end{tabular}


Neste exemplo do documento pr4, o mesmo tradutor que traduziu articles of association por contrato social acima aqui traduziu o mesmo termo como "estatutos e contratos sociais". O contexto é uma empresa específica qualificada no documento "as well as any other in which the Grantor may hold equity in Brazil". Nesse caso, não se sabe se as sociedades em questão serão limitadas ou anônimas, e o tradutor explicitou que os documentos constitutivos em questão poderiam ser tanto contratos sociais quanto estatutos sociais. Também foi classificada como uma correção pelos mesmos motivos mencionados acima.

Nos seguintes exemplos os tradutores tiveram a dificuldade esperada de como traduzir os nomes dos dois documentos constitutivos quando no Brasil só há um documento com a mesma função.

\begin{tabular}{|l|l|l|}
\hline Arquivo & Original & Tradução \\
\hline dc3_uk-brE & $\begin{array}{l}\text { Memorandum of Association and } \\
\text { Articles of Association of } \\
\text { Company1 } \\
\text { Incorporated }\end{array}$ & $\begin{array}{l}\text { Instrumento de ConstituiçãoEF e } \\
\text { Estatutos SociaisMT da Sociedade } \\
\text { Companhia1 } \\
\text { Constituída }\end{array}$ \\
\hline dc2_uk-brB (7) & $\begin{array}{l}\text { Memorandum and Articles of } \\
\text { Association }\end{array}$ & $\begin{array}{l}\text { Protocolo de ConstituiçãoM e } \\
\text { Contrato SocialMT }\end{array}$ \\
\hline dc4_uk-brE & $\begin{array}{l}\text { The Memorandum of Association } \\
\text { of the Company }\end{array}$ & $\begin{array}{l}\text { O Instrumento de ConstituiçãoEF } \\
\text { da Sociedade }\end{array}$ \\
& & \\
\hline
\end{tabular}

Articles of Association foi traduzido com uma modulação, como nos exemplos anteriores, e Memorandum of Association por equivalência funcional (2 vezes pelo mesmo tradutor) e por uma modulação. 


\subsubsection{Documentos constitutivos no Brasil}

Aqui vemos muitos dos mesmos problemas já vistos acima, mas no sentido contrário. O termo articles of association é utilizado apenas na Grã-Bretanha (exceto no caso de associações sem fins lucrativos nos EUA, que não estão representados no corpus ing-br). Pretendi incluir só traduções feitas para o inglês norte-americano mas é possível que uma ou outra tenha realmente sido feita para o inglês britânico (e o tradutor não sinalizou) ou que tenha havido uma mescla de terminologias. Esta mescla poderia ser o resultado de uma tradução feita para umas das regiões pertencentes ao Reino Unido (p.ex. British Virgin Islands, Cayman Islands), mas que têm leis próprias, freqüentemente mais próximas às leis dos Estados Unidos da América.

\begin{tabular}{|l|l|l|}
\hline Arquivo & Original & Tradução \\
\hline $\begin{array}{l}\text { co52_br- } \\
\text { usK }\end{array}$ & na forma de seu contrato social & $\begin{array}{l}\text { as set forth under its articles of } \\
\text { association }^{\mathrm{MP}}\end{array}$ \\
\hline
\end{tabular}

Neste exemplo, a empresa em questão é uma sociedade anônima, e portanto teria um estatuto social e não um contrato social. De qualquer forma, como não existe uma equivalência operacional exata nesse caso, a tradução é uma modulação em que um todo é substituído por uma parte.

\begin{tabular}{|c|c|c|}
\hline Arquivo & Original & Tradução \\
\hline $\begin{array}{l}\text { dc52_br- } \\
\text { usD (18) }\end{array}$ & contrato social & $\operatorname{articles~of~association~}^{\mathrm{MP}}$ \\
\hline $\begin{array}{l}\text { dc54_br- } \\
\text { usnE (8) }\end{array}$ & contrato social & $\operatorname{articles~of~association~}^{\mathrm{MP}}$ \\
\hline $\begin{array}{l}\text { dc52_br- } \\
\text { usD }\end{array}$ & $\begin{array}{l}\text { e nos atos constitutivos e demais } \\
\text { documentos societários da sócia } \\
\text { majoritária. }\end{array}$ & $\begin{array}{l}\text { and as set forth in the articles of } \\
\text { association }^{\mathrm{MP}} \text { and other company } \\
\text { documents of the majority quotaholder. }\end{array}$ \\
\hline dc51_br- & contrato social & articles of organization $^{\mathrm{MP}}$ \\
\hline
\end{tabular}




\begin{tabular}{|l|l|l|}
\hline usL (3) & & \\
\hline $\begin{array}{l}\text { dc53_br- } \\
\text { usnE (8) }\end{array}$ & contrato social & operating agreement ${ }^{\mathrm{EF}}$ \\
\hline $\begin{array}{l}\text { co60_br- } \\
\text { usP }\end{array}$ & $\begin{array}{l}\text { XXX Ltda. ... representada na } \\
\text { forma de seus atos constitutivos }\end{array}$ & $\begin{array}{l}\text { XXX Ltda. .. represented in this act } \\
\text { according to its } \\
\text { incorporation. }\end{array}$ \\
\hline
\end{tabular}

Os documentos dc51 a dc54 são contratos sociais. Nos documentos dc52 e dc54, o termo contrato social (e atos constitutivos) foi traduzido como articles of association de maneira consistente: uma modulação em que o todo é substituído pela parte. Observe, porém, que "Articles of Association" existem somente na Grã-Bretanha e os documentos foram traduzidos para o inglês norte-americano. No documento dc51 a tradução do termo como articles of organization é consistente com o tipo de sociedade (limitada) e o país da língua de chegada (EUA). Porém, é uma modulação do mesmo tipo. A solução empregada no documento dc53 é uma equivalência funcional.

A sociedade mencionada no contrato co60 é uma sociedade limitada, mas o nome de seus atos constitutivos (que seria seu contrato social) vem traduzido como se fosse uma sociedade limitada. Porém, podemos considerar esta solução uma modulação em que o todo é substituído pela parte.

\begin{tabular}{|l|l|l|}
\hline Arquivo & Original & Tradução \\
\hline dc50_br-usL (2) & estatuto social & by-laws $^{\mathrm{MP}}$ \\
\hline dc50_br-usL (7) & regimento interno & association rules $^{\mathrm{EF}}$ \\
\hline
\end{tabular}

O documento dc50 é o estatuto social de uma sociedade brasileira sem fins lucrativos. No sistema norte-americano, este tipo de sociedade é um non-profit corporation, que tem articles of incorporation e bylaws (igual a uma corporation com fins lucrativos). Nesse caso, uma possível equivalência operacional parcial teria sido estatuto social / articles of incorporation e regimento interno / bylaws. Porém, nesse documento o tradutor escolheu traduzir estatuto 
social com o nome de um dos documentos americanos e traduziu regimento interno com uma equivalência funcional que descreve o termo em português.

\begin{tabular}{|c|c|c|}
\hline Arquivo & Original & Tradução \\
\hline $\begin{array}{l}\text { co61_br- } \\
\text { usQ }\end{array}$ & $\begin{array}{l}\text { na forma dos respectivos } \\
\text { Estatutos Sociais }\end{array}$ & $\begin{array}{l}\text { under the terms of their respective } \\
\text { corporate by-laws }^{\mathrm{MP}}\end{array}$ \\
\hline
\end{tabular}

Este documento é um contrato entre duas sociedades anônimas. Como no exemplo logo acima, a solução é uma modulação

\begin{tabular}{|l|l|l|}
\hline Arquivo & Original & Tradução \\
\hline $\begin{array}{l}\text { co51_br- } \\
\text { usD }\end{array}$ & $\begin{array}{l}\text { de acordo com seus atos } \\
\text { constitutivos }\end{array}$ & $\begin{array}{l}\text { herein represented pursuant to its articles } \\
\text { of incorporation }\end{array}$ \\
\hline
\end{tabular}

Este exemplo também utiliza uma modulação em que um todo é substituído por um termo que representa uma parte. Os atos constitutivos mencionados no último exemplo são de uma sociedade anônima, e o contexto (um contrato) não é tão específico quanto um documento constitutivo.

\begin{tabular}{|l|l|l|}
\hline Arquivo & Original & Tradução \\
\hline pr52_br-usnM & estatuto social & constituting and operating document ${ }^{\mathrm{EF}}$ \\
\hline
\end{tabular}

Este exemplo descreve bem a função do documento representado pelo termo estatuto social. A tradução de volta (os dois documentos norte-americanos traduzidos para o português como instrumento de constituição e acordo operacional) seria uma opção interessante para as dificuldades notadas nas seções anteriores.

\begin{tabular}{|l|l|l|}
\hline Arquivo & Original & Tradução \\
\hline co50_br-usL (2) & contrato social & charter $^{\mathrm{M}}$ \\
\hline
\end{tabular}


Charter é um termo meio antiquado e é útil por ser mais genérico, especialmente quando não se sabe para qual país a tradução será enviada. Segundo Garner (1999, p. 228), um corporate charter é um "certificate of incorporation" ou "a document that one files with the secretary of state upon incorporating a business." e até "The corporate charter is often the articles of incorporation."

\begin{tabular}{|l|l|l|}
\hline Arquivo & Original & Tradução \\
\hline dc52_br-usD & $\begin{array}{l}\text { contrato social e/ou estatuto } \\
\text { social da sociedade }\end{array}$ & $\begin{array}{l}\text { Articles of Association }^{\mathrm{MP}} \\
\text { laws }^{\mathrm{MP}} \text { of the company }\end{array}$ \\
\hline
\end{tabular}

Neste exemplo, o autor escreveu "contrato social e/ou estatuto social" para ser inclusivo. A frase não faz muito sentido, pois no contexto a empresa é limitada, e teria só um contrato social. A tradução, infelizmente, é muito confusa. Articles of association para uma sociedade só existem na GB (ou só para uma associação nos EUA), e empresas não têm bylaws na GB (by-laws neste país são regulamentos de uma autoridade, não estatutos de uma empresa). Inclusive, os bylaws norte-americanos são mais ou menos equivalentes aos articles of association britânicos. Desconsiderando a mescla de terminologia de dois países diferentes de língua inglesa, os dois termos foram traduzidos com uma modulação. O tradutor poderia ter corrigido o erro no original ou empregado alguma equivalência de algum tipo para melhorar a situação.

\begin{tabular}{|l|l|l|}
\hline Arquivo & Original & Tradução \\
\hline $\begin{array}{l}\text { pr53_br- } \\
\text { usnM (2) }\end{array}$ & contrato social consolidado & $\begin{array}{l}\text { restated limited liability company } \\
\text { agreement }^{\mathrm{M}-\mathrm{EX}}\left[\underline{\text { contrato social }^{\mathrm{EMP}}}\right.\end{array}$ \\
\hline
\end{tabular}

Aqui temos uma explicitação em que o tipo de empresa é mencionado (derivado do contexto) junto com uma modulação (company agreement) inesperada (por não ser terminologia normalmente utilizada nesse contexto). Nesse caso, a LDA do tradutor era o português. Um empréstimo foi utilizado também para clarificar o termo. 


\begin{tabular}{|c|c|c|}
\hline Arquivo & Original & Tradução \\
\hline $\begin{array}{l}\text { co55_br- } \\
\text { usnH }\end{array}$ & $\begin{array}{l}\text { Toda e qualquer alteração social da } \\
\text { REPRESENTANTE, e em especial } \\
\text { sua constituição societária }\end{array}$ & $\begin{array}{l}\text { Each and every change in AGENT'S } \\
\text { company, especially concerning its } \\
\text { corporate charter }^{\mathrm{M}}\end{array}$ \\
\hline
\end{tabular}

Neste exemplo temos uma modulação que é quase uma tradução literal (com transposição). Não é uma tradução literal porque a sociedade em questão é uma limitada, não uma corporation, e portanto o adjetivo corporate não é uma tradução literal de societária.

\subsubsection{Resumo de freqüência de ocorrência e conclusões}

Em resumo, a figura 5.2 mostra a freqüência de ocorrência de soluções representando cada grau de ocorrência (veja o apêndice para os dados brutos completos) para os exemplos da seção 5.2.

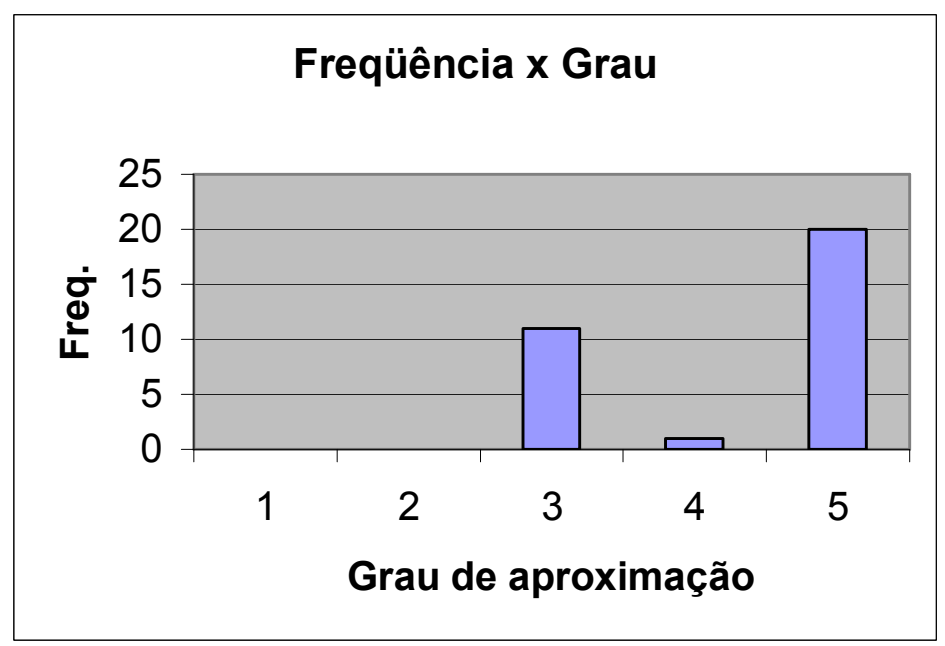

Figura 5.2 - Freqüência de ocorrência de cada grau de aproximação - documentos constitutivos

Novamente, a maioria dos resultados se encaixou no $3^{\circ}$ e no $5^{\circ}$ graus de aproximação. Observe a quase ausência de resultados representativos do $4^{\circ}$ grau (apenas 1). A tabela abaixo 
mostra as modalidades correspondentes a cada grau de aproximação e o número de ocorrências de cada modalidade para a seção 5.2.

\begin{tabular}{|l|c|c|c|c|c|}
\hline Modalidade & Grau 1 & Grau 2 & Grau 3 & Grau 4 & Grau 5 \\
\hline C & - & - & - & - & 2 \\
\hline EF & - & - & 8 & - & - \\
\hline M & - & - & 3 & - & - \\
\hline MP & - & - & - & - & 11 \\
\hline MT & - & - & - & - & 5 \\
\hline EMP+EX & - & - & - & 1 EMP-EX-M & - \\
\hline outro & - & - & - & - & 1 C-E \\
\hline outro & $\mathbf{0}$ & $\mathbf{0}$ & $\mathbf{1 1}$ & $\mathbf{1}$ & $\mathbf{2 0}$ \\
\hline totais & & & & & \\
\hline
\end{tabular}

Tabela 5.2 - Freqüência de ocorrência de modalidade por grau de aproximação documentos constitutivos

Observe o esperado número elevado de modulações nas quais o inteiro vem traduzido por uma parte (MP) no corpus br-ing (11 ocorrências) e seu contrário (MT) no corpus ing-br (5 ocorrências). Isso foi devido à falta de uma correspondência operacional, como explicado na seção 2.4, em situações em que o tradutor claramente desejava atingir o grau 5 de aproximação. Porém, as soluções tradutórias que empregaram equivalências funcionais foram na maioria bem sucedidas.

\subsection{Conceitos jurídicos}

Conceitos jurídicos são mais um tipo importante de marcador referencial na tradução jurídica, mesmo quando há correspondência entre conceitos nos dois sistemas jurídicos em questão. 


\subsubsection{Durable Power of Attorney}

O próprio tipo da procuração pr2_us-brM (Durable Power of Attorney) não existe no Brasil. No Novo Código Civil, Art. 682 (Fiuza, 2006), está escrito:

"Cessa o mandato:

I - pela revogação ou pela renúncia;

II - pela morte ou interdição de uma das partes;

III - pela mudança de estado que inabilite o mandante a conferir os poderes, ou o mandatário para os exercer;

IV - pelo término do prazo ou pela conclusão do negócio.” [grifo meu]

Portanto, foi necessária uma tradução que descreve a função do documento no país de origem, com um equivalente funcional.

\begin{tabular}{|l|l|l|}
\hline Arquivo & Original & Tradução \\
\hline pr2_us-brM & $\begin{array}{l}\text { This is a Durable Power of } \\
\text { Attorney. }\end{array}$ & $\begin{array}{l}\text { Esta é uma Procuração com poderes gerais e } \\
\text { subsistentes na incapacidade do Outorgante }\end{array}$ \\
\hline
\end{tabular}

\subsubsection{Joint Venture}

O termo joint venture já foi emprestado para o português e já se encontra dicionarizado:

"joint venture: associação de sociedades, sem caráter definitivo, para a realização de determinado empreendimento comercial, dividindo as suas obrigações, lucros e responsabilidades; consórcio [Para tudo o mais, são independentes e conservam personalidade jurídica própria, mas, na vigência da associação, cada uma delas é responsável pela totalidade do empreendimento em causa.]" (Houaiss, 2001)

\begin{tabular}{|l|l|l|}
\hline Arquivo & Original & Tradução \\
\hline $\begin{array}{l}\text { dc4_us-brE } \\
(2)\end{array}$ & joint venture & empreendimento conjunto $^{\mathrm{D}}$ \\
\hline dc2_uk-brB & joint venture & "joint venture"EMP \\
\hline
\end{tabular}


Apesar de já ser dicionarizado, no documento dc4 o termo foi traduzido através de um decalque e em dc2 como um empréstimo (como se não tivesse sido dicionarizado).

\begin{tabular}{|l|l|l|}
\hline Arquivo & Original & Tradução \\
\hline dc52_br-usD & $\begin{array}{l}\text { Contrato de Joint Venture (Joint Venture } \\
\text { Agreement) }\end{array}$ & Joint Venture Agreement \\
\hline $\begin{array}{l}\text { dcL-L-I } \\
(12)\end{array}$ & Contrato de Joint Venture & Joint Venture Agreement \\
\hline
\end{tabular}

Nesse caso, o documento dc52 já contém o termo em inglês/português, e o tradutor simplesmente transcreveu o termo na tradução.

\subsubsection{Attorney-at-law/procuração ad judicia}

No Brasil, uma procuração ad judicia outorga poderes a um advogado para representar o mandante em juízo. A procuração pr4 é uma procuração ad judicia.

\begin{tabular}{|c|c|c|}
\hline Arquivo & Original & Tradução \\
\hline pr4_ukn-brM & $\begin{array}{l}\text { and to grant powers to attorneys-at-laws in } \\
\text { order to }\end{array}$ & $\begin{array}{l}\text { outorgar mandatos a } \\
\text { advogados }^{\mathrm{EO}} \text { para }\end{array}$ \\
\hline pr4_ukn-brM & pursuant to the "ad judicia et extra" clause & $\begin{array}{l}\text { nos termos da cláusula "ad } \\
\text { judicia et extra"L-T }\end{array}$ \\
\hline
\end{tabular}

O primeiro exemplo traduz o termo attorneys-at-law como advogados, uma equivalência operacional dentro dos dois universos jurídicos. O original em inglês já é uma tradução de um documento brasileiro, e o termo em português vem transcrito para a tradução sem remover as aspas. 


\begin{tabular}{|l|l|l|}
\hline Arquivo & Original & Tradução \\
\hline pr51_br-usL & $\begin{array}{l}\text { aos quais confere todos os poderes } \\
\text { de cláusula ad judicia et extra, nos } \\
\text { termos do artigo } 5^{\circ} \text { da Lei } n^{\mathrm{o}}\end{array}$ & $\begin{array}{l}\text { on which it confers all the powers of } \\
\text { the legal representation clause }\end{array}$ \\
& $8906 / 94$, & $\begin{array}{l}\mathrm{EF} \\
\text { article } 5 \text { of Brazilian Decree Number } \\
8906 / 94,\end{array}$ \\
\hline
\end{tabular}

A procuração pr51 também é uma procuração ad judicia, e nesse caso uma equivalência funcional (na qual o objetivo da cláusula é descrito) foi empregada.

\begin{tabular}{|l|l|l|}
\hline Arquivo & Original & Tradução \\
\hline dc53_br-usnE & $\begin{array}{l}\text { É vedado aos sócios, prepostos, } \\
\text { empregados, procuradores e ao } \\
\text { Administrador da Sociedade } \\
\text { contrair obrigações }\end{array}$ & $\begin{array}{l}\text { Members, representatives, employees, } \\
\text { attorneys-at-law }{ }^{\mathrm{ME}} \text { and the Company's } \\
\text { manager may not assume obligations }\end{array}$ \\
\hline co61_br-usQ & $\begin{array}{l}\text { o(s) signatário(s) do presente } \\
\text { instrumento são seus } \\
\text { procuradores/representantes legais } \\
\text { devidamente constituídos }\end{array}$ & $\begin{array}{l}\text { the signatories to this instrument are } \\
\text { their duly constituted attorneys } \\
\text { representatives }\end{array}$ \\
\hline
\end{tabular}

No Brasil, um procurador pode ser um attorney-at-law (se for procuração ad judicia) ou attorney-in-fact (no caso de procuração comum). No primeiro exemplo, o tradutor escolheu uma das opções (attorney-at-law), excluindo a outra. No segundo exemplo, é possível que attorneys foi escolhido para englobar attorney-at-law e attorney-in-fact, mas normalmente attorney é sinônimo de attorney-at-law.

\subsubsection{Sistema de tribunais de justiça}

O sistema de justiça e o sistema de tribunais nos EUA e no Brasil são muito diferentes. Uma característica que eles têm em comum é a presença de sistemas federais e estaduais de 
tribunais. Outro elemento em comum é o conceito de recursos e tribunais de segunda instância.

\begin{tabular}{|l|l|l|}
\hline Arquivo & Original & Tradução \\
\hline col_us-brnC & $\begin{array}{l}\text { but in the event that an appeal is filed and } \\
\text { entered on the docket of an appellate court, }\end{array}$ & $\begin{array}{l}\text { mas no caso de uma apelacão } \\
\text { instaurada e lançada nos autos } \\
\text { de um } \underline{\text { Tribunal de Recursos }}{ }^{\mathrm{L}},\end{array}$ \\
\hline
\end{tabular}

Esta tradução é literal, pois os tribunais correspondentes no Brasil não têm este nome.

Nos EUA, os sistemas estaduais freqüentemente têm um Supreme Court e, abaixo disso, um Court of Appeals, um Superior Court e tribunais de primeira instância.

\begin{tabular}{|l|l|l|}
\hline Arquivo & Original & Tradução \\
\hline co1_us-brnC & State1 Supreme Judicial Court & $\begin{array}{l}\text { Supremo Tribunal Judicial de } \\
\text { State1 }^{\mathrm{L}}\end{array}$ \\
\hline
\end{tabular}

No Brasil, porém, o único Supremo Tribunal é federal. Esta tradução, portanto, é uma tradução literal do nome do tribunal.

\begin{tabular}{|c|c|c|}
\hline Arquivo & Original & Tradução \\
\hline col1_us-brN & $\begin{array}{l}\text { United States District Court for the } \\
\text { Northern District of State1 }\end{array}$ & $\begin{array}{l}\text { Corte Distrital dos Estados Unidos da } \\
\underline{\text { América }^{\mathrm{D}-\mathrm{L}}} \text { do Distrito Norte de } \\
\text { Estado1 }\end{array}$ \\
\hline co3_us-brG & $\begin{array}{l}\text { THE UNITED STATES DISTRICT } \\
\text { COURT FOR THE SOUTHERN } \\
\text { DISTRICT OF State1 }\end{array}$ & $\begin{array}{l}\text { EM JUÍZO DISTRITAL }{ }^{\mathrm{D}} \\
\underline{\text { FEDERAL }}^{\text {EX }} \text { DOS ESTADOS } \\
\underline{\text { UNIDOS }}^{\mathrm{L}} \text { PARA O DISTRITO SUL } \\
\text { DE Estado1; }\end{array}$ \\
\hline
\end{tabular}


A primeira tradução emprega um decalque para district court e uma tradução literal para United States (nesse contexto, United States é sinônimo de federal). A segunda tradução é semelhante, mas também explicita que o tribunal é federal.

\begin{tabular}{|c|c|c|}
\hline Arquivo & Original & Tradução \\
\hline $\begin{array}{l}\text { co2_us-brG } \\
\text { (2) }\end{array}$ & $\begin{array}{l}\text { state or federal court sitting in County1, } \\
\text { State1. }\end{array}$ & $\begin{array}{l}\text { juízo ou tribunal } \\
\text { estadual }^{\mathrm{E}} \text { federal ou } \\
\text { Condadol, no Estado1, País } 1 .^{\text {localizado }}\end{array}$ \\
\hline co3_us-brG & $\begin{array}{l}\text { THE COURTS OF THE State1 SITTING } \\
\text { IN XXX COUNTY }\end{array}$ & $\begin{array}{l}\text { O } \underline{\text { FORO }}^{L} \text { DO CONDADO DE } \\
\text { XXX, ESTADO DA Estado1 }\end{array}$ \\
\hline co5_us-brJ & the Courts of City4/State 1 & o foro ${ }^{\mathrm{L}}$ de City4/State1 \\
\hline
\end{tabular}

No primeiro exemplo, o tradutor explicitou os dois tipos de court, mas traduziu os modificadores através de tradução literal. Nos outros exemplos, a tradução foi literal.

\begin{tabular}{|l|l|l|}
\hline Arquivo & Original & Tradução \\
\hline pr8_ukn-brH & $\begin{array}{l}\text { any Brazilian civil, criminal or } \\
\text { administrative court, }\end{array}$ & qualquer tribunal $^{\mathrm{I}}$ \\
\hline pr4_ukn-brM & $\begin{array}{l}\text { To represent the Grantor before the courts } \\
\text { in whatever instance and before any tribunal } \\
\text { including administrative, }\end{array}$ & $\begin{array}{l}\text { Representar a Outorgante no } \\
\text { foro em geral }^{\mathrm{M}} \text {, em qualquer } \\
\text { instância }^{\mathrm{C}} \text {, juízo ou tribunal, }^{\text {end }}\end{array}$ \\
\hline
\end{tabular}

Nestes dois exemplos, o autor quer incluir qualquer tribunal ou juízo e os tradutores evitaram tradução literal, com implicitação e modulação. O termo "instance" não existe nesse sentido em inglês, e é claramente uma má tradução de um documento brasileiro por um tradutor desconhecido. O tradutor M percebeu o uso do falso cognato e corrigiu o texto.

\begin{tabular}{|l|l|l|}
\hline Arquivo & Original & Tradução \\
\hline pr6_ukn-br & Commercial Courts & Tribunais Comerciais $^{\mathrm{L}}$ \\
\hline
\end{tabular}


Commercial courts são um tipo de tribunal na Grã-Bretanha e não existem no Brasil. A solução é uma tradução literal.

A fraseologia da eleição de foro em contratos brasileiros é bastante bem estabelecida. Os exemplos abaixo são quase iguais em português, e as traduções são freqüentemente literais.

\begin{tabular}{|c|c|c|}
\hline Arquivo & Original & Tradução \\
\hline co56_br-usD & $\begin{array}{l}\text { foro da cidade de São Paulo, estado } \\
\text { de São Paulo }\end{array}$ & $\begin{array}{l}\underline{\text { court }}^{\mathrm{L}} \text { of the city of São Paulo, state } \\
\text { of São Paulo }\end{array}$ \\
\hline co57_br-usD & $\begin{array}{l}\text { foro da Cidade de São Paulo, Estado } \\
\text { de São Paulo, Brasil, }\end{array}$ & $\begin{array}{l}\underline{\text { court }}^{\mathrm{L}} \text { of the City of São Paulo, State } \\
\text { of São Paulo, < omissão de Brasil }>\end{array}$ \\
\hline co58_br-usD & $\begin{array}{l}\text { foro da Capital do Estado de São } \\
\text { Paulo }\end{array}$ & $\begin{array}{l}\underline{\text { court }}^{L} \text { of the City of São Paulo, State } \\
\text { of São Paulo }\end{array}$ \\
\hline pr54_br-usnM & $\begin{array}{l}2^{\text {a }} \text { Vara da Família e Sucessões de } \\
\text { bairro2 }\end{array}$ & $\begin{array}{l}\text { Second Court of Family and } \\
\text { Succession }^{\mathrm{L}} \text { of the bairro2 }\end{array}$ \\
\hline co52_br-usK & $\begin{array}{l}\text { foro da Capital do Estado de São } \\
\text { Paulo, }\end{array}$ & $\begin{array}{l}\frac{\text { courts }}{L}^{L} \text { of the Capital of the state of } \\
\text { São Paulo }\end{array}$ \\
\hline dc53_br-usnE & $\begin{array}{l}\text { foro Central da Capital do Estado de } \\
\text { São Paulo }\end{array}$ & $\underline{\text { court }}^{\mathrm{L}-\mathrm{O}}$ of the city of São Paulo \\
\hline co61_br-usQ & $\begin{array}{l}\text { Foro Central da Capital do Estado de } \\
\text { Estado3 }\end{array}$ & $\begin{array}{l}\text { Central Court } \\
\text { the State of Estado3, Brazil }\end{array}$ \\
\hline co50_br-usL & $\begin{array}{l}\text { Fica eleito o foro da situação do } \\
\text { Imóvel para serem dirimidas }\end{array}$ & $\begin{array}{l}\text { The parties elect the court }{ }^{\mathrm{L}} \text { of the } \\
\text { district where the property is } \\
\text { located } \\
\mathrm{EF} \text { to settle }\end{array}$ \\
\hline co51_br-usD & $\begin{array}{l}\text { As partes elegem o foro da cidade de } \\
\text { Cidade1 }\end{array}$ & $\begin{array}{l}\text { The parties elect the court } \\
\text { jurisdiction }^{\mathrm{M}} \text { of the city of Cidade1 }\end{array}$ \\
\hline co60_br-usP & $\begin{array}{l}\text { o foro do Município de São Paulo, } \\
\text { Estado de São Paulo }\end{array}$ & $\begin{array}{l}\text { the forum } \\
\text { São Paulo, State of São Paulo }\end{array}$ \\
\hline
\end{tabular}


Os exemplos abaixo contêm o termo comarca, "que designa o território, a circunscrição territorial, compreendida pelos limites em que se encerra a jurisdição de um juiz de direito." (Plácido e Silva, s/d)

\begin{tabular}{|c|c|c|}
\hline Arquivo & Original & Tradução \\
\hline co50_br-usL & $\begin{array}{l}\text { As partes elegem o Foro Central da } \\
\text { Comarca desta Capital }\end{array}$ & $\begin{array}{l}\text { Central Court }^{\mathrm{L}} \text { of the District } \\
\text { the City of Cidade1 }\end{array}$ \\
\hline $\begin{array}{l}\text { co53_br- } \\
\text { usnF }\end{array}$ & arca de Cidade6, & $\begin{array}{l}\text { Central Courts }^{L} \\
\text { Cidade6 }\end{array}$ \\
\hline co59_br-usL & Cidade2 & $\begin{array}{l}\underline{\text { venue }}^{\mathrm{M}} \text { of the judicial district } \\
\text { Cidade2 }\end{array}$ \\
\hline dc52_br-usD & $\begin{array}{l}\text { foro jurídico na respectiva Comarca } \\
\text { de Cidade3, Estado de Estado2 }\end{array}$ & $\begin{array}{l}\text { court jurisdiction }^{\mathrm{M}} \text { is in the } \\
\text { respective Judicial District }^{\mathrm{EO}} \text { of } \\
\text { Cidade3, in the state of Estado2 }\end{array}$ \\
\hline $\begin{array}{l}\text { co55_br- } \\
\text { usnH }\end{array}$ & $\begin{array}{l}\text { foro da Comarca da Capital do } \\
\text { Estado de São Paulo }\end{array}$ & $\begin{array}{l}\underline{\text { court }}^{\mathrm{L}-\mathrm{I}} \text { of the capital of the state of } \\
\text { São Paulo }\end{array}$ \\
\hline $\begin{array}{l}\text { dc54_br- } \\
\text { usnE }\end{array}$ & $\begin{array}{l}\text { foro da Comarca de São Paulo, } \\
\text { Estado de São Paulo }\end{array}$ & $\begin{array}{l}\text { the court }{ }^{L} \text { of the administrative } \\
\text { region }^{\mathrm{EF}} \text { of São Paulo, State of São } \\
\text { Paulo }\end{array}$ \\
\hline
\end{tabular}

District e Judicial district são equivalências operacionais, pois a jurisdição de courts freqûentemente é por district. A tradução County vem do fato de que o County nos EUA é uma divisão administrativa entre o municipal e o estadual. Há county courts em muitos estados norte-americanos. Comarca é implicitada no documento co55.

\subsubsection{Foro como título de cláusula}

As seguintes traduções foram todos títulos de cláusulas ou capítulos de contratos. 


\begin{tabular}{|l|l|l|}
\hline Arquivo & Original & Tradução \\
\hline co59_br-usL & FORO & VENUE $^{\mathrm{M}}$ \\
\hline co52_br-usK & DO FORO & VENUE $^{\mathrm{M}}$ \\
\hline co53_br-usnF & ELEIÇÃO DE FORO & VENUE $^{\mathrm{M}}$ \\
\hline co55_br-usnH & DO FORO & VENUE $^{\mathrm{M}}$ \\
\hline co61_br-usQ & FORO & LEGAL VENUE $^{\mathrm{M}}$ \\
\hline co51_br-usD & FORO & JURISDICTION $^{\mathrm{M}}$ \\
\hline co57_br-usD & FORO & JURISDICTION $^{\mathrm{M}}$ \\
\hline co58_br-usD & DO FORO & JURISDICTION $^{\mathrm{M}}$ \\
\hline dc53_br-usnE & DO FORO & COURT $^{\mathrm{F}}$ \\
\hline co60_br-usP & ELEIÇÃO DE FORO & SELECTION OF FORUM $^{\mathrm{M}}$ \\
\hline
\end{tabular}

Os termos venue e jurisdiction são utilizados em contratos de língua inglesa, mas não freqüentemente como o título da cláusula sobre o foro.

\begin{tabular}{|l|l|l|}
\hline Arquivo & Original & Tradução \\
\hline dc52_br-usD & DENOMINAÇÃO, SEDE E FORO & COMPANY NAME, \\
& & PRINCIPAL PLACE OF \\
& & BUSINESS AND \\
& & GOVERNING LAW $^{\text {EDV }}$ \\
\hline dc52_br-usD (2) & Leis Aplicáveis & Governing Law $^{\text {EDV }}$ \\
\hline
\end{tabular}

Nestes dois exemplos, a tradução "governing law" representa uma equivalência discursiva, por motivos que serão esclarecidos abaixo.

No sentido contrário, há um menor número de cláusulas sobre esse assunto com títulos.

\begin{tabular}{|l|l|l|}
\hline Arquivo & Original & Tradução \\
\hline
\end{tabular}




\begin{tabular}{|l|l|l|}
\hline co7_usn-brF & Governing Law and Disputes & $\begin{array}{l}\text { Legislação Regente }^{\mathrm{L}} \text { e } \\
\text { Contendas }\end{array}$ \\
\hline co6_us-brA & Governing Law & Lei Aplicável $^{\mathrm{M}}$ \\
\hline co5_us-brJ & Jurisdiction & Foro de eleição $^{\mathrm{EDV}}$ \\
\hline
\end{tabular}

O terceiro exemplo também é uma equivalência discursiva, com o emprego de um título consagrado em português ("foro de eleição" é empregado nos contratos co216_br e co211_br no corpus comparável br-orig). É interessante notar que em inglês este tipo de cláusula é normalmente intitulado Governing Law. Há 7 ocorrências no corpus comprável ing-orig desse título, e uma ocorrência em que governing law aparece junto com Venue. Não há nenhuma ocorrência de Jurisdiction como título de cláusula.

\begin{tabular}{|l|l|}
\hline Arquivo do corpus ing-orig & Texto \\
\hline $\begin{array}{l}\text { co124_us, co121_us, co120_us, co119_us, } \\
\text { co106_us, co105_us, co102_us }\end{array}$ & Governing Law \\
\hline co115_us & Governing Law and Venue \\
\hline
\end{tabular}

Jurisdiction não aparece como título de cláusula em nenhum documento no corpus ing-orig, e venue só aparece uma vez, no exemplo acima.

\subsubsection{Court of competent jurisdiction}

Esta expressão é muito utilizada, mas a palavra competent nesse sentido é um pouco arcaica. No contexto jurídico, competente significa:

competent $=(1)$ (of a judge or court) having jurisdiction or authority to act [ex. when a court of competent jurisdiction has obtained control of property, that control may not be disturbed by any other court]; 
Ou em outras palavras, competent jurisdiction nesse sentido é redundante. É o tribunal com jurisdição.

\begin{tabular}{|l|l|l|}
\hline Arquivo & Original & Tradução \\
\hline $\begin{array}{l}\text { dc4_uk-brE, } \\
\text { co6_us-brA }\end{array}$ & court of competent jurisdiction & foro da jurisdição competente $^{\mathrm{L}}$ \\
\hline dc2_uk-brB & court of competent jurisdiction & tribunal com jurisdição competente $^{\mathrm{L}}$ \\
\hline co8_us-brF & court of competent jurisdiction & tribunal de jurisdição competente $^{\mathrm{L}}$ \\
\hline co6_us-brA & court of competent jurisdiction & tribunal da jurisdição competente $^{\mathrm{L}}$ \\
\hline
\end{tabular}

Todos os exemplos acima são traduções literais, com alterações na preposição segundo o ouvido do tradutor. A expressão "jurisdição competente" não ocorre nenhuma vez no corpus br-orig.

\begin{tabular}{|l|l|l|}
\hline Arquivo & Original & Tradução \\
\hline co2_us-brG & court of competent jurisdiction & juízo ou tribunal $^{\text {EX }}$ competente $^{\mathrm{I}}$ \\
\hline
\end{tabular}

Esta solução exclui a redundância mencionada acima com uma implicitação, mas ao mesmo tempo usa um binômio de quase sinônimos para traduzir court.

\subsubsection{Caso fortuito e força maior}

Estes dois termos, e os termos correspondentes (baseado no significado técnico jurídico) em inglês, são difíceis devido ao falso cognato (parcial) "força maior" / force majeure. As seguintes definições ajudam a clarificar os significados dos termos:

CASO FORTUITO: Direito civil. Fato jurídico strictu sensu extraordinário ou irresistível em que o acidente que gera o dano advém de causa desconhecida, como, por exemplo, o cabo elétrico aéreo que se rompe e cai sobre fios telefônicos, causando incêndio ou a explosão de caldeira de usina, provocando 
morte. Pode ser ocasionado por ato de terceiros, como greve, motim, mudança de governo, colocação do bem fora do comércio, que cause graves acidentes ou prejuízos, devido à impossibilidade do cumprimento de certas obrigações. (Diniz, 2005) (grifos meus)

CASO DE FORÇA MAIOR: Direito civil. Fato jurídico stricto sensu extraordinário ou irresistível, por ser originário de fato da natureza que produz prejuízo, como, por exemplo, raio que provoca incêndio ou inundação que danifica produtos, implicando uma idéia de relatividade, já que a força do acontecimento é maior do que a suposta, devendo-se fazer uma consideração prévia do estado do sujeito e das circunstâncias espácio-temporais para que se caracterize como eficácia liberatória de responsabilidade civil. (Diniz, 2005) (grifos meus)

Todos os casos, que se revelam por força maior, dizem-se casos fortuitos...(Plácido e Silva, s/d)

act of god. An overwhelming, unpreventable event caused exclusively by forces of nature, such as an earthquake, flood or tornado. (Garner, 1999)

force majeure. An event or effect that can be neither anticipated nor controlled. The term includes both acts of nature (e.g. floods and hurricanes) and acts of people (e.g. riots, strikes, and wars). (Garner, 1999)

Dadas estas definições, podemos criar uma tabela de correspondências:

\begin{tabular}{|l|l|l|}
\hline Tabela de Correspondências & $\begin{array}{l}\text { Causado pela } \\
\text { natureza }\end{array}$ & $\begin{array}{l}\text { Causado por um fato da } \\
\text { natureza ou por ato de terceiros }\end{array}$ \\
\hline português & força maior & caso fortuito \\
\hline inglês & act of god & force majeure \\
\hline
\end{tabular}


As traduções encontradas incluem duas equivalências operacionais (nas quais os conceitos são equivalentes nos dois universos jurídicos) e outras traduções parcialmente erradas nas quais um termo menos abrangente vem traduzido por um termo mais abrangente ou vice-versa.

\begin{tabular}{|l|l|l|}
\hline Arquivo & Original & Tradução \\
\hline co59_br-usL (2) & 21. FORÇA MAIOR & 21. ACTS OF GOD \\
\hline $\begin{array}{l}\text { co59_br-usL } \\
\text { plural, 5 singular })\end{array}$ & casos fortuitos ou de força maior. & acts of God. $^{\mathrm{MP}}$ \\
\hline co55_br-usnH & força maior & force majeure $^{\mathrm{MT}}$ \\
\hline
\end{tabular}

Havia o mesmo problema de falso cognato no sentido contrário.

\begin{tabular}{|l|l|l|}
\hline Arquivo & Original & Tradução \\
\hline $\begin{array}{l}\text { co4_us-brJ; } \\
\text { co6_us-brA }\end{array}$ & force majeur & força maior $^{\mathrm{MP}}$ \\
\hline
\end{tabular}

\subsubsection{Good faith / Boa-fé}

O conceito de boa-fé existe também no universo jurídico norte-americano e britânico sob o nome good faith. Há 7 ocorrências de good faith no corpus comparável ing-orig (6 no arquivo co124 e 1 no arquivo co127) e 5 ocorrências no corpus comparável br-orig (nos arquivos co248, co242, co240, co234, e co201).

As respectivas definições são:

boa-fé - Sempre se teve boa-fé no sentido de expressar a intenção pura, isenta de dolo ou engano, com que a pessoa realiza o negócio ou executa o ato, certa de que está agindo na conformidade do direito, conseqüentemente, protegida pelos preceitos legais. 
Dessa forma, quem age de boa-fé está capacitado de que o ato de que é agente, ou do qual participa, está sendo executado dentro do justo e do legal.

É, assim, evidentemente, a justa opinião, leal e sincera, que se tem a respeito do fato ou do ato, que se vai praticar, opinião esta tida sem malícia e sem fraude, porque, se se diz justa, é que está escoimada de qualquer vício, que lhe empane a pureza da intenção. (Plácido e Silva, s/d)

good faith (n.) A state of mind consisting in (1) honesty in belief or purpose, (2) faithfulness to one's duty or obligation, (3) observance of reasonable commercial standards of fair dealing in a given trade or business, or (4) absence of intent to defraud or to seek unconscionable advantage. good-faith (adj.) (Garner, 1999)

Observe que o adjetivo leva hífen e o substantivo não (em inglês). A grande maioria das traduções é literal, nos dois sentidos, como os exemplos abaixo mostram (os exemplos representam todas as ocorrências nos corpora).

\begin{tabular}{|c|c|c|}
\hline Arquivo & Original & Tradução \\
\hline $\begin{array}{l}\text { co4_us-brJ, dc4_uk-brE (5), } \\
\text { co3_us-brG, co2_us-brG, } \\
\text { co7_usn-brF }\end{array}$ & in good faith & de boa fé ${ }^{L}$ \\
\hline $\begin{array}{l}\text { co3_us-brG, dc2_uk-brB } \\
\text { (2), pr2_us-brM }\end{array}$ & in good faith & em boa fé ${ }^{L}$ \\
\hline dc2_uk-brB & are disclosed good faith & revelados de boa fé ${ }^{L}$ \\
\hline dc2_uk-brB & $\begin{array}{l}\text { the person acted honestly and in } \\
\text { good faith }\end{array}$ & $\begin{array}{l}\text { a honestidade da conduta e } \\
\underline{\text { boa fé }}^{\mathrm{M}} \text { de uma pessoa }\end{array}$ \\
\hline
\end{tabular}


Nos exemplos acima, good faith é empregado como substantivo. O terceiro exemplo "are disclosed good faith" provavelmente foi um erro de datilografia no original. O último exemplo contém uma modulação na qual a preposição "in" é omitida. No original, a pessoa atuou em boa-fé, e na tradução a pessoa é de boa-fé.

Havia dois casos de modulação em que o negativo mais o termo foi traduzido como o negativo do termo. Este tipo de modulação foi bastante raro nos corpora.

\begin{tabular}{|l|l|l|}
\hline Arquivo & Original & Tradução \\
\hline pr2_us-brM & $\begin{array}{l}\text { However, my Agent shall be liable for } \\
\text { willful misconduct or the failure to act in } \\
\text { good faith }\end{array}$ & $\begin{array}{l}\text { Todavia, minha Procuradora } \\
\text { será responsável por má } \\
\text { conduta intencional ou má fé }\end{array}$ \\
\hline dc1_us-brE & an act or omission not in good faith & um ato ou omissão de má fé \\
\hline
\end{tabular}

Nos exemplos seguintes, o termo good faith foi utilizado como adjetivo (apesar da falta de hífen).

\begin{tabular}{|l|l|l|}
\hline Arquivo & Original & Tradução \\
\hline co3_us-brG & $\begin{array}{l}\text { (or, in the good faith judgment of the Bank, } \\
\text { raise a substantial question as to whether it } \\
\text { is) unlawful }\end{array}$ & $\begin{array}{l}\text { (ou caso haja uma dúvida } \\
\text { significativa, no parecer } e m \\
\text { boa fé }{ }^{\mathrm{L}} \text { do Banco, quanto a sua } \\
\text { legalidade), }\end{array}$ \\
\hline $\begin{array}{l}\text { co6_us-brA } \\
(2)\end{array}$ & the good faith pursuit of the foregoing. & a boa-fé $e^{\mathrm{L}}$ de \\
\hline
\end{tabular}

Nestes dois casos, havia uma transposição do adjetivo para o substantivo, que é a forma comum em português. As únicas ocorrências de boa-fé em documentos no corpus br-ing foram no documento constitutivo de52. 


\begin{tabular}{|l|l|l|}
\hline Arquivo & Original & Tradução \\
\hline $\begin{array}{l}\text { dc52_br-usD } \\
(2)\end{array}$ & de boa fé & in good faith $^{\mathrm{L}}$ \\
\hline dc52_br-usD & $\begin{array}{l}\text { As sócias envidarão seus melhores esforços, } \\
\text { agindo de boa fé, }\end{array}$ & $\begin{array}{l}\text { The quotaholders shall attempt } \\
\text { in good faith }\end{array}$ \\
\hline
\end{tabular}

O primeiro exemplo foi literal, o contrário dos exemplos acima no sentido inverso. No segundo exemplo, porém, o tradutor omitiu o sentido de "melhores esforços" ou julgou que good faith inclui tanto o sentido de boa fé quanto o sentido de melhores esforços (best efforts). É impossível saber agora qual foi o caso.

A uniformidade das soluções foi inesperada dada a não uniformidade das traduções apresentadas em Aubert (2005b). Naquele trabalho, foram coletadas traduções de várias frases e comparados os resultados. Uma das frases contém o termo good faith como adjetivo:

The parties will exercise reasonable good faith efforts to resolve the dispute.

As traduções foram:

1. As Partes [ora contratantes] envidarão seus melhores esforços [empenhar-se-ão razoavelmente], de boa fé ${ }^{\mathrm{L}}$, para dirimir a presente dúvida/disputa.

2. As Partes buscarão utilizar esforços justos ${ }^{\mathrm{M}}$ na solução da disputa.

3. As Partes empreenderão todos os esforços cabíveis de boa fét ${ }^{\mathrm{L}}$, para dirimir o pleito.

4. As Partes empreenderão, de boa fé ${ }^{\mathrm{L}}$, todos os esforços cabíveis para dirimir o pleito.

5. As Partes envidarão de boa fé ${ }^{\mathrm{L}}$ esforços razoáveis para resolver a controvérsia.

6. As partes envidarão $\underline{\text { de boa fé }}^{\mathrm{L}}$ os esforços possíveis para solucionar o litígio

7. As Partes envidarão esforços para solucionar a controvérsia, com moderação e boa-fét $^{\mathrm{L}}$.

8. $\quad \overline{A s}$ Partes envidarão todos os esforços possíveis $^{\mathrm{M}}$ para resolver a questão.

9. As Partes envidarão, em medida razoável, esforços de boa-fé $\tilde{e}^{\mathrm{L}}$ para resolver a disputa.

10. As Partes farão uso de razoáveis esforços de boa-fée ${ }^{\mathrm{L}}$ para a solução da controvérsia.

11. As Partes imbuir-se-ão de esforços $\underline{\text { bem intencionados }}^{\mathrm{M}}$ para resolver a disputa. 
12. As Partes se empenharão, dentro do razoável e de boa fé ${ }^{\mathrm{L}}$, para resolver a pendência.

13. As partes, $\underline{\text { de boa } \boldsymbol{f e}^{\mathrm{L}}}$, envidarão esforços para dirimir o litígio.

14. Para dirimir a controvérsia, as partes comprometem-se a envidar esforços $\underline{\mathbf{e m}}$ $\underline{\text { boa-fé }}^{\mathrm{L}}$, dentro de parâmetros razoáveis. (Aubert, 2005b)

Das 14 soluções, 11 utilizaram boa-fé com ou sem uma preposição. Os outros casos são especialmente interessantes por eliminar tanto good faith quanto reasonable, ou em outras palavras, usar uma modulação que englobaria o sentido da expressão reasonable good faith como um todo. Estas traduções-"justos", "possíveis" e "bem intencionados"—foram empregadas somente uma vez cada. A tradução 8 pode ser considerada bem arriscada, pois "todos os esforços possíveis" é muito mais forte do que "reasonable good faith efforts".

\subsubsection{Best efforts}

Garner (1999) define best efforts como: "Dilligent attempts to carry out an obligation. As a standard, a best-efforts obligation is stronger than a good-faith obligation." Este conceito não existe no direito do Brasil, e quando o decalque aparece em documentos brasileiros, é geralmente devido à interferência da linguagem jurídica de língua inglesa de traduções anteriores.

\begin{tabular}{|c|c|c|}
\hline Arquivo & Original & Tradução \\
\hline co11_us-brN & $\begin{array}{l}\text { Licensee shall undertake its best } \\
\text { efforts to }\end{array}$ & $\begin{array}{l}\text { A Licenciada deverá envidar seus } \\
\underline{\text { maiores esforços }}^{\mathrm{D}}\end{array}$ \\
\hline co4_us-brJ & shall put forth their best efforts to & $\begin{array}{l}\text { empregarão seus melhores esforços } \\
\text { para }\end{array}$ \\
\hline
\end{tabular}

Estes dois exemplos trazem dois decalques semelhantes.

\begin{tabular}{|l|l|l|}
\hline Arquivo & Original & Tradução \\
\hline co51_br-usD & O Locador se compromete em envidar seus & Landlord undertakes to \\
\hline
\end{tabular}




\begin{tabular}{|l|l|l|}
\hline & $\underline{\text { melhores esforços }}$ & endeavor to <omissão> \\
\hline dc52_br-usD & $\begin{array}{l}\text { As sócias envidarão seus melhores esforços, } \\
\text { agindo de boa fé, }\end{array}$ & $\begin{array}{l}\text { The quotaholders shall attempt } \\
\text { in good faith <omissão> }\end{array}$ \\
\hline co52_br-usK & Aplicar todo zelo, & Put forth its $\underline{\text { best efforts }}^{\mathrm{EO}}$, \\
\hline
\end{tabular}

Os primeiros dois exemplos omitem o sentido de best efforts, apesar de o conceito ser do inglês jurídico. Este tipo de solução foi inesperado. O terceiro exemplo traduz uma expressão em português por uma equivalência operacional.

\subsubsection{Termos jurídicos em latim}

O termo nolle prosequi, segundo seu uso em inglês jurídico, é

nolle prosequi (vb.) To abandon (a suit or prosection); to have a case dismissed by a nolle prosequi.

No exemplo abaixo, uma equivalência funcional que descreve o conceito em outras palavras foi utilizada.

\begin{tabular}{|l|l|l|}
\hline Arquivo & Original & Tradução \\
\hline dc4_uk-brE & the entering of a nolle prosequi & arquivamento do processo $^{\mathrm{EF}}$ \\
\hline
\end{tabular}

A tradução do termo pari passo utilizou uma transcrição. Infelizmente, o termo tem significados diferentes em inglês jurídico e em português jurídico.

pari passu [Latin "by equal step"] Proportionally; at an equal pace; without preference (ex. Creditors of a bankrupt estate will receive distributions pari passu.) (Garner, 1999) 
Esta definição se encaixa no contexto em inglês, especialmente o significado "sem preferência".

\begin{tabular}{|l|l|l|}
\hline Arquivo & Original & Tradução \\
\hline dc3_uk-brE & the issue of shares pari passu & emissão de ações pari passu $^{\text {T-ER }}$ \\
\hline dc3_uk-brE & $\begin{array}{l}\text { issue of further shares ranking pari } \\
\text { passu therewith. }\end{array}$ & $\begin{array}{l}\text { emissão de mais ações classificadas } \\
\text { pari passu }^{\text {T-ER }} \text { com aquelas }\end{array}$ \\
\hline
\end{tabular}

Infelizmente, o significado em português tem mais a ver com tempo

PARI PASSU. Locução latina. A passo igual; simultaneamente; aquilo que ocorre concomitantemente. (Diniz, v. 3, p. 591, 2005)

Portanto, a transcrição da expressão em latim é um erro.

\subsubsection{Regime de casamento}

Há 4 regimes de casamento no Brasil:

- o regime de separação de bens

- o regime de comunhão parcial de bens

- o regime de comunhão universal de bens

- o regime de participação final nos aqüestos (Fiuza, 2006)

Nos Estados Unidos, o regime depende do estado. Cerca de 10 estados são Community Property States, onde casamentos são celebrados segundo regras semelhantes ao regime de comunhão parcial de bens no Brasil.

\begin{tabular}{|l|l|l|}
\hline Arquivo & Original & Tradução \\
\hline $\begin{array}{l}\text { pr54_br- } \\
\text { usnM }\end{array}$ & pelo regime da comunhão parcial de bens & $\begin{array}{l}\text { under the community property } \\
\text { system }^{\text {EO }}\end{array}$ \\
\hline
\end{tabular}


\begin{tabular}{|l|l|lll}
\hline co50_br-usL & pelo regime da comunhão universal de bens & under the full community
\end{tabular} (2) anteriormente à vigência da Lei $\mathrm{n}^{\circ} 6.515 / 77$ property regime $^{\mathrm{M}-\mathrm{L}}$ before Law No. $6515 / 77$ took effect

O primeiro exemplo aproveita das semelhanças entre os dois sistemas justamente para o regime de comunhão parcial, e utiliza uma equivalência operacional. O segundo exemplo usa uma modulação baseada parcialmente na mesma equivalência e parcialmente em uma tradução literal.

\subsubsection{Resumo de freqüência de ocorrência e conclusões}

Em resumo, a figura 5.3 mostra a freqüência de ocorrência de soluções representando cada grau de ocorrência (veja o apêndice para os dados brutos completos) para os exemplos da seção 5.3 .

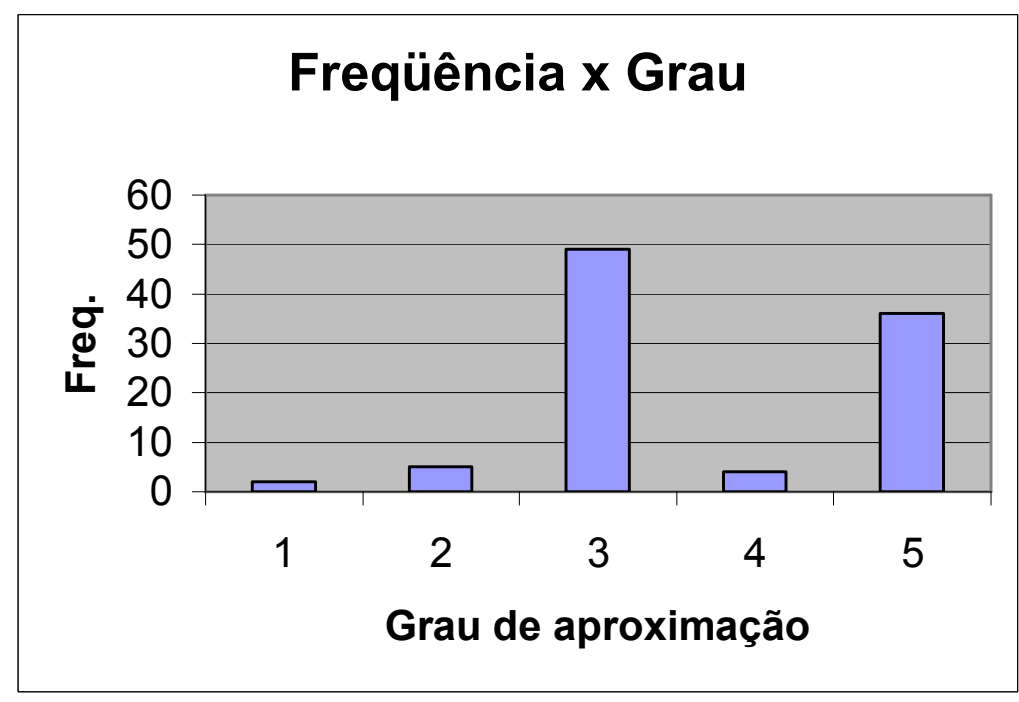

Figura 5.3 - Freqüência de ocorrência de cada grau de aproximação - conceitos jurídicos

São poucas as soluções tradutórias dos graus 1, 2 e 4 . As soluções tradutórias de grau 2 foram principalmente decalques, como "empreendimento conjunto" como tradução para o termo inglês "joint venture" e "maiores esforços" para o termo inglês "best efforts". 


\begin{tabular}{|c|c|c|c|c|c|}
\hline Modalidade & Grau 1 & Grau 2 & Grau 3 & Grau 4 & Grau 5 \\
\hline $\mathrm{C}$ & & & & & 1 \\
\hline $\mathrm{D}$ & & 3 & & & \\
\hline $\mathrm{EC}$ & & & & & 1 \\
\hline EDV & & & & & 3 \\
\hline $\mathrm{EF}$ & & & 4 & 1 & \\
\hline EMP & & & 1 & & \\
\hline $\mathrm{EO}$ & & & & & 7 \\
\hline EX-L & & & 1 & & \\
\hline $\mathrm{I}$ & & & 1 & & \\
\hline $\mathrm{L}$ & & 1 & 21 & 1 & 12 \\
\hline L-T & & & & & 2 \\
\hline $\mathrm{M}$ & & 1 & 14 & & 4 \\
\hline $\mathrm{ME}$ & & & & & 1 \\
\hline MP & & & & & 3 \\
\hline MT & & & & & 1 \\
\hline $\mathrm{O}$ & & & 3 & & \\
\hline outro & 2 ER-T & & $\begin{array}{c}1 \text { L-M } \\
1 \text { L-O } \\
1 \text { I-L } \\
1 \text { EX-I }\end{array}$ & $\begin{array}{c}1 \mathrm{D}-\mathrm{L} \\
1 \mathrm{D}-\mathrm{EX}-\mathrm{L}\end{array}$ & $1 \mathrm{I}-\mathrm{L}-\mathrm{T}$ \\
\hline totais & 2 & 5 & 49 & 4 & 36 \\
\hline
\end{tabular}

Tabela 5.3 - Freqüencia de ocorrência de modalidade por grau de aproximação - conceitos jurídicos

Três dos casos de grau 4 já contiveram as palavras "United States" ou o nome de um estado no original, e foram traduzidos literalmente. O baixo número de soluções de grau 4 vem do tipo de marcador (conceitos jurídicos). O grande número de traduções literais é devido, em 179 
parte, à feliz coincidência de "good faith" corresponder a "boa fé", que certamente não ocorre em qualquer par de idiomas.

\subsection{Diferenças nos sistemas financeiros}

\subsubsection{Quotaholder}

Em português, sócios de sociedades limitadas são quotistas e têm quotas. Porém, nos EUA os sócios de uma Limited Liability Company são members e têm membership interests. Por algum motivo desconhecido, a tradução do português para inglês criou dois termos novos que não existem no inglês — quotaholder e quota — como traduções para quotista e quota.

Em inglês norte-americano, os termos correspondentes são claros e consagrados:

\begin{tabular}{|l|l|l|}
\hline Termo & Corporation & LLC \\
\hline $\begin{array}{l}\text { Como se chama o } \\
\text { (co-)proprietário }\end{array}$ & Shareholder & Member \\
\hline $\begin{array}{l}\text { O que pertence ao } \\
\text { (co-)proprietário }\end{array}$ & Shares of stock & Membership interest \\
\hline
\end{tabular}

(Steingold, 2001, p. 1/21)

O corpus traz muitos exemplos do uso de quotaholder e quota.

\begin{tabular}{|l|l|l|}
\hline Arquivo & Original & Tradução \\
\hline $\begin{array}{l}\text { dc51_br-usL (6) } \\
\text { (singular e plural) }\end{array}$ & quotista & quotaholder $^{\mathrm{D}}$ \\
\hline co50_br-usL (2) & quotistas & quota holders $^{\mathrm{D}}$ \\
\hline dc52_br-usD (many) & sócio & quotaholder $^{\mathrm{D}}$ \\
\hline dc54_br-usnE & quotista & quotaholder $^{\mathrm{D}}$ \\
\hline
\end{tabular}


Nestes quatro exemplos, o termo quotaholder é utilizado até para traduzir sócio (de uma sociedade limitada). Este tipo de decalque representa uma interlíngua entre os dois idiomas e universos jurídicos.

\begin{tabular}{|l|l|l|}
\hline Arquivo & Original & Tradução \\
\hline dc53_br-usnE (muitos) & quotista & member $^{\mathrm{EO}}$ \\
\hline pr53_br-usnM & quotista gerente & $\begin{array}{l}\text { managing } \\
\text { gerente] }^{\mathrm{EMP}}\end{array}$
\end{tabular}

Neste primeiro exemplo, quotista foi traduzido através de equivalência operacional. No segundo, foi traduzido da mesma maneira, mas com um empréstimo acompanhante.

\begin{tabular}{|l|l|l|}
\hline Arquivo & Original & Tradução \\
\hline $\begin{array}{l}\text { dc51_br-usL (6), } \\
\text { dc52_br-usD (50), } \\
\text { dc54_br-usnE singular e } \\
\text { plural }\end{array}$ & quota & quota $^{\text {EMP }}$ \\
\hline co50_br-usL & & \\
\hline dc53_br-usnE & quotas ou ações & \\
\hline
\end{tabular}

Os dois primeiros exemplos utilizam um empréstimo, pois o significado do termo "quota" em inglês é diferente do significado de "quota" em português. O último exemplo utiliza uma modulação. Share é normalmente o nome utilizado para corporations (dc53 é para uma sociedade limitada).

\begin{tabular}{|l|l|l|}
\hline Arquivo & Original & Tradução \\
\hline pr4_ukn_brM (5); & quota & quota $^{\mathrm{T}}$ \\
pr8_ukn-brH (2) & & \\
singulare plural & & \\
\hline
\end{tabular}




\begin{tabular}{|l|l|l|}
\hline pr8_ukn-brH & $\begin{array}{l}\text { as a quotaholder of the Brazilian } \\
\text { company }\end{array}$ & $\begin{array}{l}\text { na qualidade de sócia- } \\
\text { quotista }^{\mathrm{C}} \text { da sociedade }\end{array}$ \\
\hline $\begin{array}{l}\text { dc2_uk-brB (many), } \\
\text { dc4_uk-brE (many) }\end{array}$ & member & sócio $^{\mathrm{EO}}$ \\
\hline
\end{tabular}

Os primeiros dois exemplos, arquivos que já foram identificados como escritos por autores cuja língua de domínio mais ativo não era o inglês, contêm os termos quota e quotaholder como se fossem termos ingleses. O terceiro exemplo mostra o uso de member no contexto de sociedades limitadas, com a tradução sócio, equivalente a quotista nesse contexto.

\subsubsection{Retirar talões e pagar contas através de boleto bancário}

Na procuração pr50 vemos um conceito específico à cultura de partida e não presente na cultura de chegada.

\begin{tabular}{|l|l|l|}
\hline Arquivo & Original & Tradução \\
\hline pr50_br-usL & $\begin{array}{l}\text { retirar talões de cheques, retirar cheques } \\
\text { depositados e devolvidos, }\end{array}$ & $\begin{array}{l}\text { pick up }{ }^{\mathrm{EF}} \text { checkbooks, pick } \\
\text { up deposited and returned } \\
\text { checks, }\end{array}$ \\
\hline
\end{tabular}

No Brasil, é necessário ir ao banco para pagar contas, retirar talões/cheques, etc. Porém, nos EUA, cheques são encomendados pelo correio de uma gráfica especializada. Alguns bancos enviam cópias de cheques depositados e devolvidos (ou os próprios cheques) para o cliente junto com o estrato todo mês, e outros fornecem cópias no site do banco na Internet. O norteamericano vai ao banco raramente, para abrir conta ou pedir um empréstimo. Portanto, "pickup" é uma equivalência funcional obrigatória que descreve a ação de ir ao banco pegar algo.

Outro conceito específico ao sistema bancário brasileiro é a ficha de compensação.

\begin{tabular}{|l|l|l|}
\hline Arquivo & Original & Tradução \\
\hline co61-br-usQ & receber os pagamentos relativos às & receive payments related to the \\
\hline
\end{tabular}




\begin{tabular}{|l|l|l|}
\hline faturas mensais, formulários de & monthly statements, sporadic \\
pagamento avulso ou ficha de & $\begin{array}{l}\text { payment forms, or bank collection } \\
\text { compensação }\end{array}$ & sips $^{\mathrm{EF}}$ \\
\hline
\end{tabular}

Neste exemplo, uma equivalência funcional que descreve a função e a aparência da ficha de compensação foi empregada na tradução.

\subsection{3 Índices de correção monetária}

Havia no corpus br-ing as seguintes ocorrências de índices de correção monetária:

\begin{tabular}{|c|c|c|}
\hline Arquivo & Original & Tradução \\
\hline $\begin{array}{l}\text { co50_br-usL } \\
\text { (2) }\end{array}$ & $\begin{array}{l}\text { IGM-M - Índice Geral de Preços } \\
\text { do Mercado divulgado pela } \\
\text { Fundação Getúlio Vargas (FGV). }\end{array}$ & $\begin{array}{l}\text { IGP-M } \\
\text { Index }^{\mathrm{L}}-\text { Índice Geral de Preços do } \\
\left.\underline{\text { Mercado }}^{\mathrm{EMP}}\right) \text { released by the Getúlio } \\
\text { Vargas }^{\mathrm{T}} \text { Foundation }^{\mathrm{L}}(\mathbf{F G V})^{\mathrm{EMP}} \text {. }\end{array}$ \\
\hline $\begin{array}{l}\text { co50_br-usL } \\
\text { (2) }\end{array}$ & $\begin{array}{l}\text { Índice Geral de Preços, publicado } \\
\text { pela Fundação Getúlio Vargas } \\
\text { (IGP/FGV) }\end{array}$ & 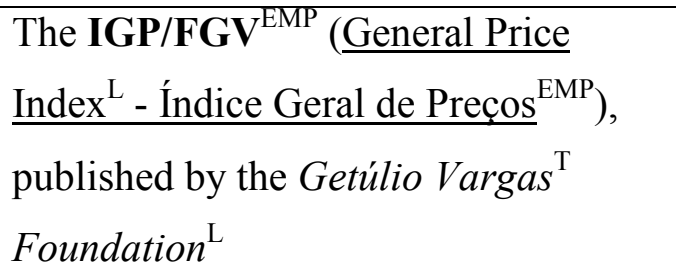 \\
\hline $\begin{array}{l}\text { co50_br-usL } \\
\text { (2) }\end{array}$ & $\begin{array}{l}\text { Índice de Preços ao Consumidor, } \\
\text { publicado pela Fundação Instituto } \\
\text { de Pesquisas da Universidade de } \\
\underline{\underline{\text { São Paulo }} \text { (IPC/FIPE). }}\end{array}$ & $\begin{array}{l}\text { the IPC/FIPE } \\
\text { Index }^{\mathrm{L}}-\text { Índice de Preços ao }^{\text {Consumer Price }} \\
\underline{\text { Consumidor }}^{\mathrm{EMP}} \text { ), published by the } \\
\text { Economic }^{\mathrm{EX}} \text { Research Institute } \\
\text { Foundation }^{\mathrm{L}} \text { of the } \underline{\underline{\text { University of São }}} \\
\underline{\underline{\text { Paulo }}}^{\mathrm{L}} \text {. }\end{array}$ \\
\hline co51_br-usD & $\begin{array}{l}\text { IGP-M/FGV (Índice Geral de } \\
\text { Preços - Mercado, publicado pela } \\
\text { Fundação Getúlio Vargas) }\end{array}$ & 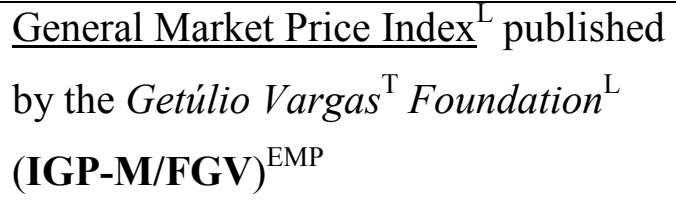 \\
\hline co51_br-usD & $\begin{array}{l}\text { IGP-DI - Índice Geral de Preços - } \\
\text { Disponibilidade Interna, publicado }\end{array}$ & $\begin{array}{l}\text { IGP-DI }^{\mathrm{EMP}} \text { : the General Price Index - } \\
\text { Domestic Availability }^{\mathrm{L}} \text {, published by }\end{array}$ \\
\hline
\end{tabular}




\begin{tabular}{|c|c|c|}
\hline & pela FGV & $\mathbf{F G V}^{\mathrm{EMP}}$ \\
\hline co51_br-usD & $\begin{array}{l}\text { IPCA - Índice de Preços ao } \\
\text { Consumidor Amplo, publicado } \\
\text { pelo } I B G E\end{array}$ & $\begin{array}{l}\text { IPCA }^{\text {EMP }}: \text { the Broad-based } \\
\text { Price Index }^{\mathrm{M}} \text {, }{ }^{\mathrm{C}} \text {, published by } I B G E^{\mathrm{EMP}} ;\end{array}$ \\
\hline co51_br-usD & $\begin{array}{l}\text { IPC - Índice de Preços ao } \\
\text { Consumidor, publicado pela FIPE. }\end{array}$ & $\begin{array}{l}\text { IPC }^{\mathrm{EMP}} \text { : the Consumer Price Index } \\
\text { published by the Institute of Economic } \\
\text { Research Foundation }^{\mathrm{L}-\mathrm{EX}} \text { of the } \\
\text { University of São Paulo } \\
\text { EX }(F I P E)^{\mathrm{EMP}}\end{array}$ \\
\hline co61_br-usQ & I.G.P.M./F.G.V & $\begin{array}{l}\text { General Market Price Index } \\
\text { (IGP-EX } \\
\left.\text { IGP }^{\mathrm{EMP}}\right) \text { published by the Getulio } \\
\text { Vargas }^{\mathrm{T}} \text { Foundation }^{\mathrm{L}-\mathrm{EX}}\end{array}$ \\
\hline co60_br-usP & $\begin{array}{l}\text { ÍNDICE GERAL DE PREÇOS } \\
\text { DE MERCADO (IGPM) }\end{array}$ & $\begin{array}{l}\text { GENERAL INDEX OF MARKET } \\
\text { PRICES }^{\mathrm{L}} \text { (IGPM, ÍNDICE GERAL }^{\text {IGP }} \\
\text { DE PREÇOS DE MERCADO) }\end{array}$ \\
\hline
\end{tabular}

Para resumir, as siglas dos índices sempre foram copiadas para a tradução através de empréstimo. O nome da "Fundação Getúlio Vargas" também foi traduzido da mesma maneira pelos três tradutores, com um empréstimo e uma tradução literal. Os nomes dos índices foram traduzidos de maneira análoga pelos quatro tradutores L, D, Q e P. A tabela abaixo apresenta somente os nomes dos índices da tabela acima.

\begin{tabular}{|l|l|l|}
\hline Arquivo & Original & Tradução \\
\hline $\begin{array}{l}\text { co50_br-usL } \\
(2)\end{array}$ & Índice Geral de Preços do Mercado & $\begin{array}{l}\text { General Market Price Index } \\
\text { Geral } \text { - Índice }\end{array}$ \\
\hline $\begin{array}{l}\text { co50_br-usL } \\
(2)\end{array}$ & Índice Geral de Preços & $\begin{array}{l}\text { General Price Index } \\
\text { de Preços }\end{array}$ \\
\hline $\begin{array}{l}\text { EMP Índice Geral } \\
(2)\end{array}$ & Índice de Preços ao Consumidor & $\begin{array}{l}\text { Consumer Price Index } \\
\text { Preços a } \text { Índice de }\end{array}$ \\
\hline co51_br-usD & Índice Geral de Preços - Mercado & General Market Price Index $^{\text {LMP }}$ \\
\hline
\end{tabular}




\begin{tabular}{|c|c|c|}
\hline co51_br-usD & $\begin{array}{l}\text { Índice Geral de Preços - } \\
\text { Disponibilidade Interna }\end{array}$ & $\begin{array}{l}\text { General Price Index - Domestic } \\
\text { Availability }^{\mathrm{L}}\end{array}$ \\
\hline co51_br-usD & $\begin{array}{l}\text { Índice de Preços ao Consumidor } \\
\text { Amplo }\end{array}$ & Broad-based $^{\mathrm{M}}$ Consumer Price Index ${ }^{\mathrm{L}}$ \\
\hline co51_br-usD & Índice de Preços ao Consumidor & Consumer Price Index ${ }^{\mathrm{L}}$ \\
\hline co61_br-usQ & I.G.P.M. & General Market Price Index ${ }^{\mathrm{L}-\mathrm{EX}}$ \\
\hline co60_br-usP & $\begin{array}{l}\text { ÍNDICE GERAL DE PREÇOS DE } \\
\text { MERCADO }\end{array}$ & $\begin{array}{l}\text { GENERAL INDEX OF MARKET } \\
\text { PRICES }^{L}\end{array}$ \\
\hline
\end{tabular}

Porém, o tradutor L utilizou uma tradução literal seguida por empréstimo de maneira consistente, e os tradutores D, Q e P utilizaram só tradução literal, com uma modulação em um caso.

\begin{tabular}{|c|c|c|}
\hline Arquivo & Original & Tradução \\
\hline co50_br-usL & Fundação Instituto de Pesquisas & $\begin{array}{l}\text { Economic }^{\mathrm{EX}} \text { Research Institute } \\
\text { Foundation }^{\mathrm{L}}\end{array}$ \\
\hline co51_br-usD & $F I P E$ & $\begin{array}{l}\text { Institute of Economic Research } \\
\text { Foundation }^{\mathrm{L}-\mathrm{EX}} \text { of the University of } \\
\text { São Paulo }\end{array}$ \\
\hline
\end{tabular}

A tradução da denominação "Fundação Instituto de Pesquisas Econômicas (FIPE)" foi difícil, por dois motivos. A palavra "Econômicas" foi omitida no original do co50, mas inserida na tradução. O segundo problema é a justaposição de fundação e instituto, que é raro em inglêsqualquer tradução soaria esquisita. No primeiro exemplo, o tradutor simplesmente inverteu a ordem das palavras em português, enquanto o tradutor do segundo exemplo modificou a ordem e explicitou a ligação com a Universidade de São Paulo. 


\subsubsection{Feriado com "ponte"}

Um outro conceito brasileiro raro nos EUA é o conceito de feriado com "ponte". Quando um feriado cai em uma terça ou quinta, muitas empresas fecham na segunda ou na sexta, respectivamente, criando uma ponte - um dia de folga a mais. Nos EUA, todos os feriados menos o dia da independência, natal e o ano novo são móveis para cair em uma segunda-feira (ou na quinta, no caso de Thanksgiving). Quando ocorre uma "ponte", o conjunto fim de semana + ponte + feriado é chamado de long weekend (observação: long weekend é utilizado também quando o feriado cai na segunda ou na sexta, criando um fim de semana com três dias).

\begin{tabular}{|c|c|c|}
\hline Arquivo & Original & Tradução \\
\hline $\begin{array}{l}\text { co54_br- } \\
\text { usnF }\end{array}$ & $\begin{array}{l}\text { com o sistema de compensação de } \\
\text { "dias-ponte", entre fins-de-semana e } \\
\text { feriados }\end{array}$ & $\begin{array}{l}\text { with the "bridge-day" }{ }^{\mathrm{D}} \text { set-off system, } \\
\text { with respect to period }^{\mathrm{EX}} \text { between } \\
\text { holidays and week-ends }\end{array}$ \\
\hline
\end{tabular}

A tradução acima utiliza um decalque junto com uma explicitação não presente no original para descrever o conceito. Este termo não recorre no documento.

\subsubsection{Impostos}

A tradução de impostos específicos é difícil, pois os impostos de diferentes países são raramente equivalentes. Nos exemplos abaixo, um qualificador indicador do país não foi incluso.

\begin{tabular}{|c|c|c|}
\hline Arquivo & Original & Tradução \\
\hline co51_br-usD & $\begin{array}{l}\text { O Imposto Predial Territorial } \\
\text { Urbano (IPTU) será pago }\end{array}$ & $\begin{array}{l}\text { The Municipal }{ }^{\mathrm{EX}} \text { Urban Land }^{\mathrm{L}} \text { and } \\
\text { Property }^{\mathrm{M}} \text { Tax (IPTU) } \\
{ }^{\mathrm{EMP}} \text { shall be paid }\end{array}$ \\
\hline co50_br-usL & IPTU & $\begin{array}{l}\text { IPTU }^{\text {EMP }} \text { (Urban Land and Building } \\
\text { Taxes }^{\mathrm{L}}-\text { Impostos Predial e Territorial } \\
\text { Urbano }^{\text {EX }}\end{array}$ \\
\hline
\end{tabular}




\begin{tabular}{|l|l|l}
\hline co59_br-usL & $\begin{array}{l}\text { Imposto sobre Serviços de } \\
\text { qualquer natureza }\end{array}$ & $\begin{array}{l}\text { Service Tax }^{\mathrm{M}} \text { (ISS }^{\mathrm{EX}} \text { - Imposto sobre } \\
\text { Serviços de Qualquer Natureza) }\end{array}$
\end{tabular}

Os três exemplos incluem a sigla (mesmo no terceiro, que não constava do original) e uma tradução literal ou uma modulação. O segundo exemplo inclui uma explicitação do nome do imposto, por extenso, nos dois idiomas.

\subsubsection{Resumo de freqüência de ocorrência e conclusões}

Em resumo, a figura 5.4 mostra a freqüência de ocorrência de soluções representando cada grau de ocorrência (veja o apêndice para os dados brutos completos) para os exemplos da seção 5.4 .

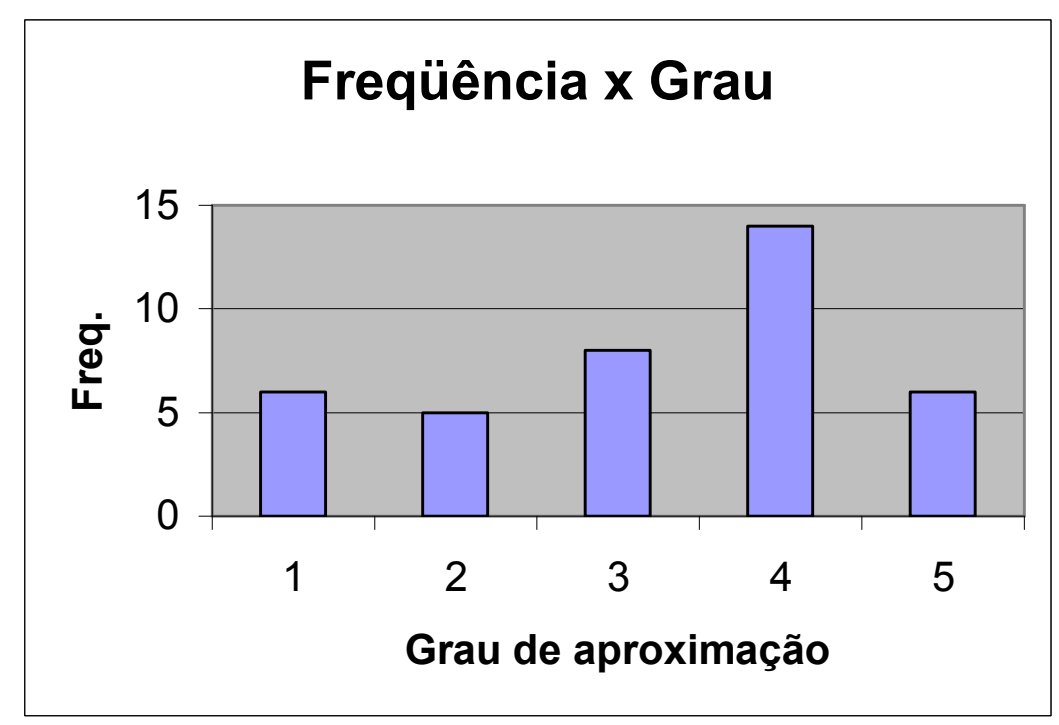

Figura 5.4 - Freqüência de ocorrência de cada grau de aproximação - conceitos financeiros

Ao contrário dos resultados das seções anteriores, aqui temos uma número relativamente grande de soluções de grau 4, e um número elevado de soluções de grau 1 (todos empréstimos sem outra modalidade). Este número elevado de soluções de grau 4 se deve ao assuntoconceitos financeiros - e à tradução de índices financeiros nacionais. 


\begin{tabular}{|c|c|c|c|c|c|}
\hline Modalidade & Grau 1 & Grau 2 & Grau 3 & Grau 4 & Grau 5 \\
\hline $\mathrm{C}$ & - & - & - & - & 1 \\
\hline $\mathrm{D}$ & - & 4 & - & - & - \\
\hline$\overline{\mathrm{EF}}$ & - & - & 2 & - & - \\
\hline$\overline{\text { EMP }}$ & 6 & - & - & - & - \\
\hline EMP-EX-L & - & - & 1 & 2 & - \\
\hline EMP-L & - & - & 3 & 4 & - \\
\hline $\mathrm{EO}$ & - & - & - & - & 3 \\
\hline EX-L & - & - & - & 1 & - \\
\hline L-T & - & - & - & 2 & - \\
\hline $\mathrm{M}$ & - & - & 1 & - & - \\
\hline $\mathrm{T}$ & - & - & - & - & 2 \\
\hline EMP+outro & - & - & 1 EMP-L-M & $\begin{array}{l}1 \text { EMP-EO } \\
1 \text { EMP-L-T }\end{array}$ & - \\
\hline $\begin{array}{l}\text { EMP+EX } \\
\pm \text { outro }\end{array}$ & - & - & - & $\begin{array}{c}1 \text { EMP-EX-L-M } \\
1 \text { EMP-EX-M }\end{array}$ & - \\
\hline outro & - & $1 \mathrm{D}-\mathrm{EX}$ & - & $1 \mathrm{EX}-\mathrm{L}-\mathrm{T}$ & - \\
\hline totais & 6 & 5 & 8 & 14 & 6 \\
\hline
\end{tabular}

Tabela 5.4 - Freqüência de ocorrência de modalidade por grau de aproximação - conceitos financeiros

As soluções são bem distribuídas pelas diferentes modalidades, sem destaques exceto talvez para empréstimo com tradução literal com/sem outra modalidade também empregada ao mesmo tempo (as categorias EMP-L, EMP-EX-L, EMP+outro e EMP+EX \pm outro), 9 soluções com empréstimo e tradução literal no total. 


\subsection{Qualificações de pessoas físicas e jurídicas}

Como mostrado na seção 2.2 sobre procurações, um elemento presente em toda procuração brasileira e na maioria de contratos e atos constitutivos nos dois idiomas é a qualificação das partes interessadas. Todas as procurações no corpus ing-br contêm as informações completas típicas da procuração brasileira. Algumas foram escritas em inglês incorreto ou traduzidas para o inglês do português por tradutores desconhecidos. (Veja a seção 4.4 para mais detalhes sobre cada procuração.) Somente o corpus br-ing será analisado aqui, pois a ocorrência de $\mathrm{RG}$, etc. em documentos escritos em inglês é devida a uma tradução anterior ao contrário para o inglês por um tradutor desconhecido e de um original desconhecido.

\subsubsection{Cédula de identidade RG}

RG (Registro Geral) é a sigla que identifica a cédula de identidade emitida por cada estado (pela Secretaria de Segurança Pública - SSP). O CPF (Cadastro de Pessoas Físicas) é outra cédula - ela não contém uma fotografia do portador, é emitida pelo governo federal e é utilizada para fins de declaração de imposto de renda, entre outros. Todo brasileiro tem um RG e um CPF. Estrangeiros residentes no Brasil têm uma cédula de identidade de estrangeiro, conhecido como RNE (Registro Nacional de Estrangeiros) e um CPF. O RNE é emitido pela Polícia Federal.

Nos EUA, é necessário ter um Social Security number, emitido pela U.S. Social Security Administration, uma agência federal, para muitos fins, inclusive para trabalhar. Esse número é também utilizado por fins de declaração de imposto de renda e, como o CPF, a cédula não contém fotografia. Não existe algo equivalente ao RG e o cidadão não é obrigado (por lei) a carregar um documento de identidade consigo. O equivalente cultural do RG nos EUA é a carteira de motorista (drivers license), que contém fotografia e é válida por 4 anos (isso pode depender do estado). Este equivalente cultural seria empregado na situação tradutória A2, na qual o original serve de modelo, mas a tradução é uma adaptação ou localização para o país da língua de chegada. Para quem não dirige, a mesma agência estadual que emite o drivers license também emite um State ID cuja aparência é quase igual à do drivers license. Em 
muitos estados, o órgão emissor da carteira de motorista e do State ID (ou Personal ID) é o Department of Motor Vehicles, mas em Michigan, por exemplo, o Secretary of State é responsável por esse serviço.

A dificuldade inicial na análise das traduções de RG e suas variantes foi definir a unidade de estudo. O objetivo é comparar as diversas formas das ocorrências, sem enfatizar suas diferenças. Em alguns casos, só a sigla RG aparece. Em outros, RG é suplementado pela palavra "número", pela palavra "cédula" ou pelas duas — "cédula" e "número". Nas traduções, vemos que as traduções literais de "cédula" e "número" são omissas ou explicitadas de maneira aparentemente aleatória. Baseado no conceito de especificação, no qual a diferença entre "Cédula de identidade" e "Cédula de identidade RG" é apenas uma explicitação de sentido, as duas expressões serão analisadas como apenas uma unidade. Para esta subanálise, vou supor que as palavras "cédula" e "número" eram implícitas no original quando aparecem na tradução. Assim, sua aparência na tradução seria classificada como uma explicitação nesses casos.

Apresento na tabela a seguir os trechos nos quais aparece RG no corpo do documento. As ocorrências de RG no final de documentos (junto com as assinaturas para identificar os assinantes) serão analisadas em seguida.

\begin{tabular}{|l|l|l|}
\hline Arquivo & Original & Tradução \\
\hline $\begin{array}{l}\text { pr50_br- } \\
\text { usL }\end{array}$ & RG 0 & $\begin{array}{l}\text { with Brazilian Identification Number } \\
\underline{(\mathbf{R G})}^{\text {EMP }} 0\end{array}$ \\
\hline $\begin{array}{l}\text { pr51_br- } \\
\text { usL }\end{array}$ & $\begin{array}{l}\text { portador da Cédula de } \\
\text { Identidade RG n }{ }^{\text {o }} 0\end{array}$ & with Brazilian Identification $^{\text {EX-EF-1 Number 0 }}$ \\
\hline
\end{tabular}

Nestes exemplos, uma combinação de explicitação (Brazilian) com equivalência funcional foi utilizada. No segundo exemplo, a sigla $R G$ não foi transferida para a tradução. $O$ primeiro exemplo explicita "number", e o segundo implicita "cédula". 


\begin{tabular}{|c|c|c|}
\hline Arquivo & Original & Tradução \\
\hline $\begin{array}{l}\text { dc51_br-usL } \\
\text { (2) }\end{array}$ & $\begin{array}{l}\text { portador do CPF } \mathrm{n}^{\circ} 0 \text { e } \mathbf{R G} \mathrm{n}^{\circ} \\
0, S S P / S P\end{array}$ & $\begin{array}{l}\text { with ... and Brazilian Identity Card } \\
\text { Number } 0 \text { issued by the São Paulo } \\
\text { Secretary of Public Safety }\end{array}$ \\
\hline dc51_br-usL & $\begin{array}{l}\text { portador da } \underline{\text { cédula }} \text { de } \\
\text { identidade RG n. } 0 \text { SSP/SP, }\end{array}$ & $\begin{array}{l}\text { with ... and Brazilian Identity Card } \\
\text { Number } 0 \text { issued by the São Paulo } \\
\text { Secretary of Public Safety }\end{array}$ \\
\hline $\begin{array}{l}\text { co50_br-usL } \\
\text { (8) }\end{array}$ & $\begin{array}{l}\text { portador da Cédula de } \\
\text { Identidade R.G. } n^{\circ} 0-\underline{\underline{X X} / \mathrm{XX}}\end{array}$ & $\begin{array}{l}\text { bearer of Brazilian Identity } \text { Card }^{\mathrm{EX}-\mathrm{L}} \\
(\mathbf{R G})^{\mathrm{EMP}} \text { No. } 0-\underline{\underline{\mathrm{XX}} / \mathrm{XX}}\end{array}$ \\
\hline co55_br-usnH & $\begin{array}{l}\text { portador da Cédula de } \\
\text { Identidade } \mathbf{R G} \mathrm{n}^{\mathrm{o}} 0-\mathrm{SSP} / \mathrm{SP}\end{array}$ & $\begin{array}{l}\text { bearer of the Brazilian Identity Card } \\
\text { (RG) }{ }^{\mathrm{EMP}} \text { No. } 0 \text { - SSP/SP }\end{array}$ \\
\hline co55_br-usnH & $\begin{array}{llr}\text { portador da cédula } & \text { de } \\
\text { identidade } & \mathbf{R G} \mathrm{n}^{\circ} 00000 & \end{array}$ & $\begin{array}{l}\text { bearer of the Brazilian Identity Card } \\
\text { (RG) }{ }^{\mathrm{EMP}} \text { No. } 00000\end{array}$ \\
\hline
\end{tabular}

Todos estes exemplos utilizam a expressão "Brazilian Identity Card". Esta solução é uma combinação de explicitação (Brazilian) com tradução literal (cédula de identidade = identity card), exceto no primeiro exemplo, no qual o conceito de cédula é implícito, não explícito. RG ocorre na tradução (empréstimo) nos últimos 3 exemplos.

\begin{tabular}{|c|c|c|}
\hline Arquivo & Original & Tradução \\
\hline pr52_br-usnM & $\begin{array}{l}\text { portador da cédula de identidade } \\
\text { RG no. } 0 \mathrm{SSP} / \mathrm{SP}\end{array}$ & $\begin{array}{l}\text { holder of the identity card }{ }^{\mathrm{L}} \text { No. }^{\mathrm{ER}} \\
\text { RG }^{\mathrm{EMP}} \text { no. } 0 \mathrm{SSP} / \mathrm{SP}\end{array}$ \\
\hline pr53_br-usnM & $\begin{array}{l}\text { portador da cédula de identidade } \\
\text { RG no. 0/SSP-SP }\end{array}$ & 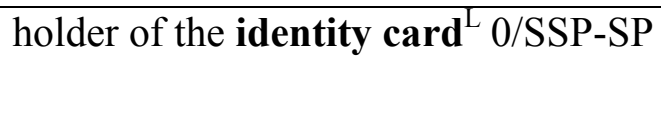 \\
\hline $\begin{array}{l}\text { pr53_br-usnM } \\
\text { (2) }\end{array}$ & $\begin{array}{l}\text { portador da cédula de identidade } \\
\text { RG no. 0/SSP-SP }\end{array}$ & $\begin{array}{l}\text { holder of the identity card }{ }^{\mathrm{L}} \text { No. } \\
\text { RG }^{\mathrm{EMP}} 0\end{array}$ \\
\hline $\begin{array}{l}\text { dc53_br-usnE } \\
\text { (2) }\end{array}$ & $\begin{array}{l}\text { portador da Cédula de Identidade } \\
\underline{\text { RG n } 0 \text {, expedida pela SSP/SP }}\end{array}$ & $\begin{array}{l}\text { bearer of Identity Card }{ }^{\mathrm{L}} \underline{\mathrm{RG}}^{\mathrm{EMP}} \text { No. } 0 \text {, } \\
\text { issued by the Public Security } \\
\text { Department of the State of São Paulo }\end{array}$ \\
\hline
\end{tabular}




\begin{tabular}{|l|l|l|}
\hline & & SSP/SP \\
\hline pr54_br-usnM & $\begin{array}{l}\text { portador da cédula de identidade } \\
\text { de } \mathbf{R G} \mathbf{n}^{\mathbf{0}} \text { 0-SSP/SP }\end{array}$ & $\begin{array}{l}\text { holder of Identity } \mathbf{C a r d}^{\mathrm{L}} \mathbf{R G}^{\mathrm{EMP}} \text { No. } \\
\text { 0-SSP/SP }\end{array}$ \\
\hline co54_br-usnF & $\begin{array}{l}\text { portador da Cédula de Identidade } \\
\text { RG } 0\end{array}$ & $\begin{array}{l}\text { bearer of Identity } \text { Card }^{\mathrm{L}} \mathbf{n o}^{\text {RG }} \mathbf{R G}^{\mathrm{EMP}} 0 \\
\end{array}$ \\
\hline
\end{tabular}

Nestes exemplos, não há explicitação (Brazilian) e há tradução literal (cédula de identidade = identity card) em todos os exemplos. Todos os exemplos menos o segundo incluem a sigla RG na tradução (empréstimo).

As seguintes traduções são apresentadas separadamente por serem de outro contexto, no fim do documento em baixo de assinaturas.

\begin{tabular}{|l|l|l|}
\hline Arquivo & Original & Tradução \\
\hline co56_br-usD (2) & RG.: & RG $^{\mathrm{EMP}}$ Identity $^{\mathrm{EF}}$ No.: \\
\hline co59_br-usL (2) & RG & Personal Identification Number \\
\hline dc53_br-usnE & RG & $\mathrm{RG}^{\mathrm{EMP}}$ \\
\hline
\end{tabular}

Elas são mais breves do que as soluções acima, com somente uma (ou em um caso duas) modalidades empregadas.

Aubert (2005b) apresenta 8 traduções de "cédula de identidade RG" por 10 tradutores diferentes:

\begin{tabular}{|l|l|}
\hline Tradutores & Tradução \\
\hline 2 & ID Card $^{\mathrm{L}-\mathrm{O}} \underline{\text { No. }}^{\mathrm{EX}}$ \\
\hline 2 & Identity Card $^{\mathrm{L}} \mathrm{RG}^{\mathrm{EMP}}$ \\
\hline 2 & ID Card $^{\mathrm{L}}-\mathrm{RG}^{\mathrm{EMP}} / \mathrm{Id}^{\text {. Card }}{ }^{\mathrm{L}} \mathrm{RG}^{\mathrm{EMP}}$ \\
\hline 1 & IDENTIFICATION CARD $^{\mathrm{L}-\mathrm{O}}$ \\
\hline
\end{tabular}




\begin{tabular}{|c|c|}
\hline 1 & identification card ${ }^{\mathrm{L}-\mathrm{O}} N o{ }^{\mathrm{EX}}$ \\
\hline 1 & Identity Card $^{\mathrm{L}-\mathrm{O}}$ \\
\hline \begin{tabular}{|l|l}
1 \\
\end{tabular} & Identity $\operatorname{Card}^{\mathrm{L}}$ ["RG”] EMP \\
\hline
\end{tabular}

Observe as mesmas tendências em termos de empréstimo vistas no presente estudo. Como o original especificou explicitamente o RG (e não uma cédula de identidade de aluno ou do CREA ou da $\mathrm{OAB}$ ) eu marquei traduções que não explicitaram isso de alguma maneira (p.ex. cédula de identidade estadual) como omissão. Apesar das soluções diversas, vemos poucas diferenças em termos de abordagem:

\begin{tabular}{|l|l|}
\hline Tradutores & Abordagem por modalidade \\
\hline 5 & EMP-L \\
\hline 3 & EX-L-O \\
\hline 2 & L-O \\
\hline
\end{tabular}

A diferença maior entre os resultados desse estudo e os de Aubert foi a completa ausência da explicitação "Brazilian" nos resultados de Aubert. Além disso, não houve nenhum exemplo de equivalência funcional, mas isso talvez se deva à forma da expressão original, que explicitou "cédula de identidade".

A pouca dispersão dos dados de Aubert - em termos de abordagem — pode ser devida em parte ao fato de todos os tradutores serem juramentos (e portanto a suposição de que a tradução do trecho em questão deveria ser juramentada também), e em parte ao fato do texto original ser igual para todas as ocorrências.

\subsubsection{Análise da sigla SSP/SP}

A sigla SSP/SP representa a Secretaria de Segurança Pública do estado de São Paulo. No documento co50, a sigla XXX/XX representa a SSP de algum estado não identificado. 


\begin{tabular}{|l|l|l|}
\hline Arquivo & Original & Tradução \\
\hline dc51_br-usL (3) & $\underline{\text { SSP/SP }}$ & $\begin{array}{l}\text { issued by } \\
\text { Public Safety }\end{array}$ \\
\hline dc53_br-usnE (2) & expedida pela SSP/SP & $\begin{array}{l}\text { issued by the Public Security Department } \\
\text { of the State of São Paulo }\end{array}$ \\
\hline $\begin{array}{l}\text { pr53_br-usnM, SSP/SP } \\
\text { co5P_br-usnH, } \\
\text { pr52_br-usnM } \\
\text { pr54_br-usnM, } \\
\text { co50_br-usL }\end{array}$ & $\underline{\text { SSP-SP (ou XXX/XX) }}$ & $\begin{array}{l}\text { SSP-SP } \\
\text { EMP (ou XXX/XX }\end{array}$ \\
\hline pr53_br-usnM (2) & SSP-SP & \\
\hline
\end{tabular}

A sigla SSP/SP foi explicitada em somente dois documentos, pelos tradutores L e E. No primeiro exemplo, a tradução foi literal, enquanto no segundo houve modulação dos termos segurança e secretaria.

\subsubsection{Outras qualificações de pessoas físicas - OAB e RNE}

Como mencionado acima, outros órgãos emitem cédulas de identidade. Associações de classe como a $\mathrm{OAB}$ e o CREA emitem cédulas de identidade que contém o número RG e podem ser utilizados em lugar deste documento. O RNE (Registro Nacional de Estrangeiros) é o equivalente do RG para estrangeiros residentes no país.

\begin{tabular}{|c|c|c|}
\hline Arquivo & Original & Tradução \\
\hline dc51_br-usL & inscrito na $\mathrm{OAB} / \mathrm{SP}$ n. 0 & $\begin{array}{l}\text { member No. } 0 \text { of the } \text { Brazilian Bar } \\
\text { Association }^{\mathrm{EX}-\mathrm{EO}} \text {, São Paulo State Chapter } \\
(\mathrm{OAB} / \mathrm{SP})^{\mathrm{EMP}}\end{array}$ \\
\hline pr51_br-usL & $\mathrm{OAB}^{-S P} \mathrm{~N}^{\circ} 0$ & $\begin{array}{l}\text { OAB-SP }^{\text {EMP }} \text { (Order of Brazilian Lawyers }{ }^{\mathrm{L}} \text {, São } \\
\left.\text { Paulo, Enrollment Number }{ }^{\mathrm{EXP}}\right) \mathrm{N}^{\mathrm{o}} 0\end{array}$ \\
\hline
\end{tabular}




\begin{tabular}{|l|l|l|}
\hline $\begin{array}{l}\text { pr51_br-usL } \\
(4)\end{array}$ & OAB-SP N 0 & OAB-SP ${ }^{\mathrm{EMP}} \mathrm{N}^{\mathrm{o}} 0$ \\
\hline
\end{tabular}

Nos exemplos acima, todos do mesmo tradutor, a sigla OAB foi traduzida de três maneiras diferentes. No primeiro exemplo, uma explicitação (Brazilian) foi utilizada com uma equivalência operacional (é o Bar Association que registra advogados nos EUA). O significado da sigla SP "São Paulo State Chapter" também foi explicitado. No segundo exemplo, a tradução foi literal, com uma explicitação "enrollment number". A sigla OAB-SP foi sempre mantida (empréstimo)

\begin{tabular}{|c|c|c|}
\hline Arquivo & Original & Tradução \\
\hline $\begin{array}{l}\text { pr50_br- } \\
\text { usL }\end{array}$ & $\begin{array}{l}\text { portadora de RNE A000000- } \\
\text { B }\end{array}$ & $\begin{array}{l}\text { bearer of Brazilian Resident } \\
\text { (RNE) }^{\mathrm{M}}{ }^{\mathrm{EMP}} \text { Adentity Card } \\
\text { AX00000-B }\end{array}$ \\
\hline $\begin{array}{l}\text { dc54_br- } \\
\text { usnE }\end{array}$ & $\begin{array}{l}\text { portador da Cédula de } \\
\text { Identidade RNE } 0\end{array}$ & $\begin{array}{l}\text { holder of foreigners }{ }^{\mathrm{L}} \mathrm{RNE}^{\mathrm{EMP}} \text { identity } \text { card }^{\mathrm{L}} \\
\text { No. } 0\end{array}$ \\
\hline $\begin{array}{l}\text { dc53_br- } \\
\text { usnE (2) }\end{array}$ & $\begin{array}{l}\text { portador do } \underline{\text { RNE }} \mathrm{n}^{\mathrm{o}} 0 \text {, } \\
\text { expedido pelo DPF }\end{array}$ & $\begin{array}{l}\text { bearer of Identity Card } \\
\text { by the Federal Police Department (DPF) }\end{array}$ \\
\hline
\end{tabular}

Todas as soluções nos exemplos acima mantêm a sigla RNE (empréstimo). A primeira solução utiliza uma modulação e uma explicitação. A segunda utiliza tradução literal. A terceira utiliza explicitação.

\subsubsection{Qualificação de pessoas jurídicas - CNPJ, JUCESP}

JUCESP é a sigla para a Junta Comercial do estado de São Paulo. É um órgão do estado que registra empresas mercantis e atividades afins.

\begin{tabular}{|l|l|l|}
\hline Arquivo & Original & Tradução \\
\hline $\begin{array}{l}\text { co50_us-brL } \\
(2)\end{array}$ & $\begin{array}{l}\text { arquivado na Junta Comercial do } \\
\text { Estado de São Paulo }\end{array}$ & $\begin{array}{l}\text { filed with the São Paulo } \\
\text { Trade }^{\mathrm{T}} \text { (JUCESP) }^{\mathrm{EMP}} \text { State Board of }\end{array}$ \\
\hline
\end{tabular}




\begin{tabular}{|c|c|c|}
\hline & (“JUCESP”) sob n 0 & \\
\hline $\begin{array}{l}\text { pr53_br-usnM } \\
\text { (2) }\end{array}$ & registrado na JUCESP sob no. & $\begin{array}{l}\text { filed with JUCESP }{ }^{\mathrm{EMP}} \text { [Registry of } \\
\text { Commerce }^{\mathrm{EF}} \text { for the State of São } \\
\text { Paulo] }^{\mathrm{EX}} \text { under No. } 0\end{array}$ \\
\hline dc54_br-usnE & JUCESP & $\begin{array}{l}\text { São Paulo State Division of } \\
\text { Corporations }^{\text {EX-M }}\end{array}$ \\
\hline dc53_br-usnE & $\begin{array}{l}\text { Junta Comercial do Estado de } \\
\text { São Paulo - JUCESP }\end{array}$ & $\begin{array}{l}\text { State of São Paulo }{ }^{\mathrm{L}} \text { Commercial } \\
\text { Registry }^{\mathrm{M}} \text { (JUCESP }^{\mathrm{EMP}} \text { ) }\end{array}$ \\
\hline
\end{tabular}

O termo Board of Trade utilizado no primeiro exemplo é o nome de um tipo de organização não governamental que apóia sociedades na região que representa. Nos EUA, há um Board of Trade em quase toda metrópole, e filiação é facultativa. $\mathrm{O}$ órgão que registra sociedades nos EUA é estadual, e na maioria de estados é o "Secretary of State". Este seria o equivalente operacional. No entanto, Mello (1998) sugere a tradução Board of Trade para Junta Comercial. O primeiro exemplo, portanto, é classificado como uma modulação junto com transcrição e empréstimo. O segundo exemplo emprega empréstimo, equivalência funcional e explicitação. O terceiro e quarto exemplos são do mesmo tradutor, mas são bem diferentes. $\mathrm{O}$ terceiro utiliza explicitação e modulação e não utiliza empréstimo. O quarto utiliza empréstimo, tradução literal e uma modulação diferente do exemplo anterior.

Todas as sociedades brasileiras são cadastradas com um órgão estadual e outro federal (a receita federal). A receita cadastra as sociedades no Cadastro Nacional de Pessoa Jurídica (CNPJ). O nome antigo era Cadastro Geral de Contribuintes (CGC). Não analisarei a tradução (ou não) de MF (Ministério da Fazenda). Observe que a sigla CNPJ é quase sempre explicitada através de uma tradução de seu significado.

\begin{tabular}{|l|l|l|}
\hline Arquivo & Original & Tradução \\
\hline co50_br-usL & $\begin{array}{l}\text { inscrita no } \underline{\mathrm{CGC}} \mathrm{MF} \\
\text { sob n } 0\end{array}$ & $\begin{array}{l}\text { enrolled in the } \text { Brazilian }^{\mathrm{EX}} \text { corporate }^{\mathrm{M}} \\
\text { taxpayers }^{\mathrm{EF}} \text { registry }\end{array}$ \\
\hline
\end{tabular}




\begin{tabular}{|c|c|c|}
\hline $\begin{array}{l}\text { co59_br-usL, } \\
\text { dc50_br-usL }\end{array}$ & $\underline{\mathrm{CNPJ}}$ & $\begin{array}{l}\text { Brazilian }^{\mathrm{EX}} \quad \text { Taxpayer }^{\mathrm{EF}} \quad \text { Identification }^{\mathrm{M}-\mathrm{EX}} \\
\text { Number }(\mathrm{CNPJ})^{\mathrm{EMP}}\end{array}$ \\
\hline co54_br-usnF & $\mathrm{CNPJ} / \mathrm{MF}$ & General $^{\mathrm{M}}$ Taxpayers ${ }^{\text {EF }}$ Registry ${ }^{\mathrm{L}-\mathrm{EX}}$ \\
\hline dc52_br-usD & CNPJ No. & taxpayer's $^{\mathrm{EF}-\mathrm{EX}}(\mathrm{CNPJ})^{\mathrm{EMP}}$ no. 0 \\
\hline dc52_br-usD & CNPJ No. & taxpayer $^{\mathrm{EF}}$ identity $^{\mathrm{M}-\mathrm{EX}}$ number $(\mathrm{CNPJ})^{\mathrm{EMP}} 0$ \\
\hline dc53_br-usnE & $\underline{\mathrm{CNPJ}} / \mathrm{MF} \mathrm{N}^{\circ} 0$ & Corporate $^{\mathrm{L}} \mathrm{Tax}^{\mathrm{EF}-\mathrm{EX}} \mathrm{CNPJ} / \mathrm{MF}^{\mathrm{EMP}}$ Number 0 \\
\hline pr51_br-usL & CNPJ & $\begin{array}{l}\text { National }^{\mathrm{L}} \text { Corporate }^{\mathrm{L}} \text { Taxpayers }^{\mathrm{EF}} \text { Register }^{\mathrm{L}-\mathrm{EX}} \\
(\mathrm{CNPJ})^{\mathrm{EMP}}\end{array}$ \\
\hline
\end{tabular}

Todos os exemplos acima utilizam uma equivalência funcional com a inclusão da palavra Taxpayer, que se refere à função do número em questão. O equivalente operacional nos EUA é o Employer Identification Number (EIN), emitido pela Receita Federal (Internal Revenue Service) desse país. Na maioria das traduções, uma combinação de pelo menos 3 modalidades diferentes foi utilizada, com a equivalência funcional e o empréstimo (exceto em um caso) mais alguns elementos traduzidos literalmente. A ocorrência de Identification Number no segundo exemplo pode ter sido devida ao equivalente operacional mencionado acima.

\begin{tabular}{|c|c|c|}
\hline Arquivo & Original & Tradução \\
\hline co55_br-usnH & CNPJ-MF & $\begin{array}{l}\text { CNPJ-MF }^{\text {EMP }} \text { (National Registry of Legal } \\
\text { Entities) }^{\text {L-EX }}\end{array}$ \\
\hline $\begin{array}{l}\text { co56-br-usD (4), } \\
\text { co57_br-usD (2), } \\
\text { co58-br-usD (3) }\end{array}$ & $\underline{\mathrm{CNPJ}} / \mathrm{MF}$ & $\begin{array}{l}\text { National Registry of Legal Entities }{ }^{\text {L-EX }} \\
(\mathrm{CNPJ} / \mathrm{MF})^{\mathrm{EMP}}\end{array}$ \\
\hline dc51_br-usL (2) & $\underline{\mathrm{CNPJ}} / \mathrm{MF}$ & $\begin{array}{l}\text { National Register of Legal Entities }{ }^{\mathrm{L}-\mathrm{EX}} \\
{[\mathrm{CNPJ} / \mathrm{MF}]^{\mathrm{EMP}}}\end{array}$ \\
\hline pr52_br-usnM & $\begin{array}{l}\text { inscrita no } \underline{\mathrm{CNPJ}} / \mathrm{MF} \\
\text { sob no. } 0\end{array}$ & $\begin{array}{l}\text { enrolled in the national register of legal entities } \\
\text { EX } \\
\text { L- the Brazilian Ministry of Finance under } \\
\text { CNPJ/MF }\end{array}$ \\
\hline pr53_br-usnM & inscrita no $\underline{\mathrm{CNPJ}}$ & enrolled in the Brazilian ${ }^{\mathrm{EX}}$ Registry of Legal \\
\hline
\end{tabular}




\begin{tabular}{|c|c|c|}
\hline & & $\underline{\text { Entities }}^{\mathrm{L}-\mathrm{EX}}$ under No. $\underline{\mathrm{CNPJ}}^{\mathrm{EMP}} 0$ \\
\hline pr53_br-usnM & $\underline{\mathrm{CNPJ}} / \mathrm{MF}$ & $\begin{array}{l}\text { Brazilian }^{\mathrm{EX}} \text { Registry of Legal Entities } \\
\text { Ministry of Finance }\end{array}$ \\
\hline dc54_br-usnE (2) & $\begin{array}{l}\text { inscrita no } \underline{\text { CNPJ }} \text { sob } \\
\mathrm{n}^{\mathrm{o} 0}\end{array}$ & $\begin{array}{l}\text { registered at the National Registry of Legal } \\
\text { Entities }^{\text {L-EX }}(\mathrm{CNPJ})^{\mathrm{EMP}} \text { under No. } 0\end{array}$ \\
\hline co60_br-usP & $\begin{array}{l}\text { inscrita(o) no } \\
\underline{\mathrm{CNPJ} / \mathrm{MF} \text { sob o n. }{ }^{\circ} 0}\end{array}$ & $\begin{array}{l}\text { registered with the } \mathrm{CNPJ} / \mathrm{MF}^{\mathrm{EMP}} \text { [National } \\
\text { Registry of Legal Entities }{ }^{\mathrm{L}-\mathrm{EX}} / \text { Treasury Ministry] } \\
\text { under no. } 0\end{array}$ \\
\hline
\end{tabular}

Todos estes exemplos empregam tradução literal, explicitação (da sigla) e empréstimo (exceto em um caso, no qual Brazilian é explicitado).

\begin{tabular}{|l|l|l|}
\hline Arquivo & Original & Tradução \\
\hline $\begin{array}{l}\text { dc52_br-usD, pr53_br- } \\
\text { usnM, dc54_br-usnE }\end{array}$ & CNPJ & CNPJ $^{\mathrm{EMP}}$ \\
\hline
\end{tabular}

Estes exemplos utilizam só empréstimo na tradução. No documento dc52, a sigla ocorre no início do documento, na capa. No documento dc54, ela ocorre no título do documento. Nesses contextos, a modalidade empréstimo fica mais expediente.

\subsubsection{Resumo de freqüência de ocorrência e conclusões}

Em resumo, a figura 5.5 mostra a freqüência de ocorrência de soluções representando cada grau de ocorrência (veja o apêndice para os dados brutos completos) para os exemplos da seção 5.5. 


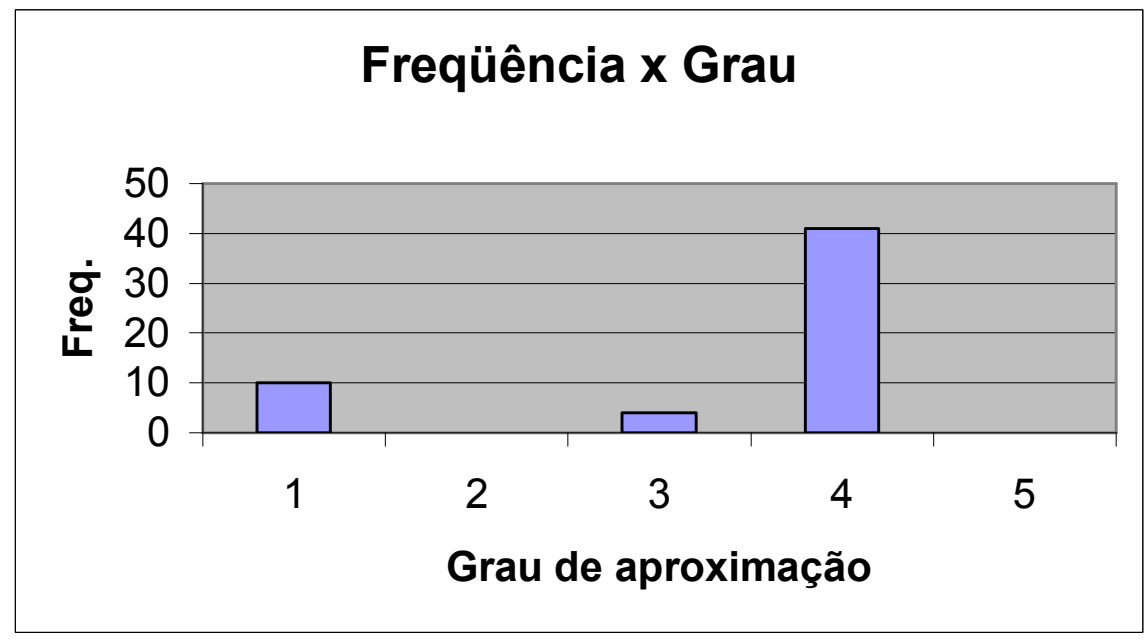

Figura 5.5 - Freqüência de ocorrência de cada grau de aproximação - qualificações

Os resultados aqui diferem sensivelmente dos resultados das seções anteriores, com a maioria das soluções representativa do grau 4 e um número razoável de soluções representativo do grau 1.

\begin{tabular}{|c|c|c|c|c|c|}
\hline Modalidade & Grau 1 & Grau 2 & Grau 3 & Grau 4 & Grau 5 \\
\hline$\overline{\mathrm{EF}}$ & - & - & 1 & - & - \\
\hline EMP & 10 & - & - & - & - \\
\hline EMP-EX-L & - & - & - & 13 & - \\
\hline EMP-L & - & - & - & 5 & - \\
\hline EX-L & - & - & - & 3 & - \\
\hline $\mathrm{L}$ & - & - & 1 & - & - \\
\hline $\mathrm{O}$ & - & - & 1 & - & - \\
\hline EMP+outro & - & - & - & 2 & - \\
\hline $\begin{array}{l}\text { EMP+EX } \\
\pm \text { outro }\end{array}$ & - & - & - & 13 & - \\
\hline outro & - & - & 1 & 5 & - \\
\hline totais & 10 & 0 & 4 & 41 & 0 \\
\hline
\end{tabular}


Tabela 5.5 - Freqüência de ocorrência de modalidade por grau de aproximação — qualificações

Basicamente, os tradutores escolheram não explicar as siglas tipo RG ou escolheram explicitar o significado através de traduções literais ou modulações, freqüentemente empregando a modalidade empréstimo como parte da solução. 


\section{Análise qualitativa e quantitativa da tradução de marcadores estilísticos}

Este capítulo analisa a tradução de marcadores estilísticos, ou seja, as convenções da linguagem jurídica dos dois universos jurídicos sob estudo. Em alguns casos, há simetria nos dois sentidos tradutórios, e em outros casos um tipo de solução é utilizado em um sentido, mas a solução correspondente não é utilizada no sentido contrário. Os termos e frases analisados são divididos em três categorias temáticas: arcaísmos, binômios tautológicos e binômios não tautológicos.

\subsection{Arcaísmos na linguagem jurídica}

Há arcaísmos na linguagem jurídica tanto em português quanto em inglês. São expressões que não existem mais fora do universo jurídico, ou existem, mas com outro sentido. Os livros sobre o estilo da escrita jurídica geralmente julgam estes arcaísmos desnecessários, mas como os exemplos abaixo mostram, o tradutor jurídico raramente os descarta. O padrão seguido pela maioria é procurar um arcaísmo ou expressão consagrada no outro idioma de chegada para traduzir um arcaísmo no idioma de partida.

\subsubsection{In witness whereof}

A expressão in witness whereof e seu uso dentro do discurso jurídico em documentos jurídicos foram tratados na seção 2.5. A expressão inicia a cláusula de conclusão de contratos e outros documentos jurídicos.

\begin{tabular}{|l|l|l|}
\hline Arquivo & Original & Tradução \\
\hline pr4_ukn-brM & IN WITNESS WHEREOF & Em testemunho do quê \\
\hline pr1_usn-brM & IN WITNESS WHEREOF & EM TESTEMUNHO DO QUÊ \\
\hline dc1_us-brE & IN WITNESS WHEREOF & Em testemunho do quê \\
\hline pr6_ukn-brE & In witness whereof & Em testemunho do quê \\
\hline co7_usn-brF & IN WITNESS OF THIS & EM TESTEMUNHO DO QUE \\
\hline
\end{tabular}




\section{AGREEMENT}

Como visto nos exemplos acima, uma tradução comum é o decalque, em que as palavras são traduzidas quase literalmente, formando uma expressão desconhecida no universo jurídico brasileiro. Esta expressão já faz parte da interlíngua de traduções do inglês ao português. Este decalque não ocorre em nenhum documento no corpus comparável br-orig.

\begin{tabular}{|l|l|l|}
\hline Arquivo & Original & Tradução \\
\hline co11_us-brN & IN WITNESS WHEREOF & $\begin{array}{l}\text { E, por estarem assim, justas e } \\
\text { contratadas }^{\text {EDV }}\end{array}$ \\
\hline
\end{tabular}

A outra solução encontrada foi a substituição dessa expressão por seu equivalente discursivo dentro do âmbito do contrato. A cláusula de conclusão em contratos brasileiros se inicia com a fraseologia "e assim, por estarem justos e acordados...". Esta frase ou algo similar foi utilizada para traduzir "in witness whereof" no exemplo acima.

\begin{tabular}{|l|l|l|}
\hline Arquivo & Original & Tradução \\
\hline co5_us-brJ & And being thus agreed, & $\begin{array}{l}\text { E, por estarem assim justas e } \\
\underline{\text { contratadas }}^{\text {EDV }}\end{array}$ \\
\hline
\end{tabular}

Neste último exemplo do corpus ing-br, o início da cláusula de conclusão omite "in witness whereof" e a tradução é mais literal naturalmente, mas ainda inclui uma equivalência discursiva, devido à tradução de agree pelo binômio "justo e acordado".

Procurei a expressão "in witness whereof" também no corpus de traduções para o inglês, para ver o motivo de seu uso.

\begin{tabular}{|l|l|l|}
\hline Arquivo & Original & Tradução \\
\hline dc52_br-usD, & E, por estarem justas e contratadas, & In witness whereof, ${ }^{\text {EDV }}$ \\
\hline
\end{tabular}




\begin{tabular}{|l|l|l|}
\hline $\begin{array}{l}\text { dc53_br-usnE, } \\
\text { co60_br-usP }\end{array}$ & \\
\hline $\begin{array}{l}\text { dc51_br-usL, } \\
\text { co58_br-usD, } \\
\text { co55_br-usnH, } \\
\text { co61_br-usQ }\end{array}$ & E, por estarem assim justas e contratadas, & In witness whereof, \\
\hline co57_br-usD & E, por assim estarem justas e contratadas, & In witness whereof, \\
\hline co56_br-usD & E, por estarem assim justas e avençadas, & $\begin{array}{l}\text { In witness whereof, the } \\
\text { parties }^{\text {EDV }}\end{array}$ \\
\hline co52_br-usK & E, por estarem assim justos e contratados, & And in witness whereof \\
\hline co61_br-usQ & E por estarem, assim, justas e contratadas & In witness whereof, \\
\hline dc5V \\
\hline
\end{tabular}

Nos exemplos acima, todos na cláusula de conclusão do documento, foram empregadas equivalências discursivas. Houve várias variações sutis na fraseologia em português.

\begin{tabular}{|l|l|l|}
\hline Arquivo & Original & Tradução \\
\hline co51_br-usD & E, por estarem assim justas e avençadas, & $\begin{array}{l}\text { The parties, hereby undertake } \\
\text { and agree }\end{array}$ \\
\hline co50_br-usL & E, por estarem assim justas e contratadas, & $\begin{array}{l}\text { And, thus considered just and } \\
\text { agreed, }^{\mathrm{M}}\end{array}$ \\
\hline
\end{tabular}

Nestes exemplos, também no final do documento, modulações parcialmente baseadas em tradução literal foram empregadas.

\begin{tabular}{|l|l|l|}
\hline Arquivo & Original & Tradução \\
\hline co52_br-usK & $\begin{array}{l}\text { têm entre si justo e contratado o } \\
\text { seguinte }\end{array}$ & $\begin{array}{l}\text { in witness whereof }^{\mathrm{EDV}} \text { agree to } \\
\text { the following }^{\mathrm{L}}\end{array}$ \\
\hline
\end{tabular}


Neste exemplo, o tradutor utilizou uma equivalência discursiva no lugar errado, pois a frase original ocorre no início do corpo do contrato, e não na cláusula de conclusão.

\begin{tabular}{|l|l|l|}
\hline Arquivo & Original & Tradução \\
\hline dc52_br-usD & $\underline{\text { Assim }}$, estando todos os sócios de & $\begin{array}{l}\text { In witness whereof } \\
\text { acordo-ER }, \text { resolvem ainda alterar por } \\
\text { being in agreement, undertake, } \\
\text { completo o contrato social }\end{array}$ \\
$\begin{array}{l}\text { furthermore, to completely amend the } \\
\text { Articles of Association }\end{array}$ \\
\hline
\end{tabular}

Neste exemplo, o texto ocorre no meio de um documento para alteração de contrato social. Novamente uma equivalência discursiva no lugar errado.

\begin{tabular}{|l|l|l|}
\hline Arquivo & Original & Tradução \\
\hline pr53_br-usnM & pediu-me e eu lhe lavrei este & $\underline{\text { In witness whereof }}^{\mathrm{M}}$, as requested, I \\
& $\begin{array}{l}\text { instrumento que depois de lido em } \\
\text { have drawn up this deed, that was } \\
\text { voz alta e clara, foi achado conforme } \\
\text { na forma redigida, outorgou, aceitou } \\
\text { e assina, dou fé. }\end{array}$ & $\begin{array}{l}\text { voice and found to be correct, and } \\
\text { thus accepted, granted and signed. }\end{array}$ \\
\hline
\end{tabular}

Neste último exemplo, a expressão "in witness whereof" foi empregada como uma modulação da expressão "dou fé", que nesse caso é a voz do escrevente que preparou o documento e não das partes interessadas.

\subsubsection{Know all men}

Segundo Garner (1995), "know all men by these presents ( = take notice ) is a flotsam phrase - as sexist as it is inscrutable to most readers - that needlessly begins many legal documents." Só há uma ocorrência no corpus ing-br e só mais uma no corpus ing-orig (co120_us). 


\begin{tabular}{|l|l|l|}
\hline Arquivo & Original & Tradução \\
\hline pr1_usn-brM & $\begin{array}{l}\text { KNOW ALL MEN BY THESE } \\
\text { PRESENTS that }\end{array}$ & $\begin{array}{l}\text { SAIBAM QUANTOS A } \\
\text { PRESENTE VIREM que }^{\text {EDV }},\end{array}$ \\
\hline
\end{tabular}

$\mathrm{Na}$ procuração acima, a fraseologia foi traduzida por seu equivalente discursivo. A mesma fraseologia foi utilizada para traduzir a fraseologia correspondente em português no corpus br-ing nos exemplos abaixo.

\begin{tabular}{|l|l|l|}
\hline Arquivo & Original & Tradução \\
\hline pr54_br_usnM & $\begin{array}{l}\text { Saibam, quantos este público } \\
\text { instrumento de procuração virem } \\
\text { que, }\end{array}$ & $\begin{array}{l}\underline{\text { KNOW ALL PERSONS }}^{\text {EDV }} \text { to } \\
\text { attorney may come that }^{\text {and notarized power of }}\end{array}$ \\
\hline pr53_br-usnM & $\begin{array}{l}\text { SAIBAM quantos este público } \\
\text { instrumento de procuração bastante } \\
\text { virem que, }\end{array}$ & $\begin{array}{l}\underline{\text { KNOW ALL PERSONS }}^{\text {whom this power of attorney granted }} \\
\text { through public deed may come that }^{\text {Shom }}\end{array}$ \\
\hline
\end{tabular}

Observe que as duas procurações pr53 e pr54 foram elaboradas por escreventes em cartórios. Somente um arquivo (pr202_br) no corpus comparável br-orig utiliza essa expressão.

\subsubsection{Witnesseth}

Este termo é mais um arcaísmo. Segundo Adams (2001, p. 12): "More often than not, recitals are preceded by the centered heading WITNESSETH, with or without underlining, a space between each letter, and other embellishments." No exemplo abaixo, a tradução de preâmbulo como witnesseth é uma equivalência discursiva baseada na posição do termo dentro do discurso/estrutura do contrato.

\begin{tabular}{|l|l|l|}
\hline Arquivo & Original & Tradução \\
\hline co53_br-usnF & $\begin{array}{l}\text { <ualificações das partes }> \\
\text { PREÂMBULO: }\end{array}$ & \begin{tabular}{l} 
qualificações das partes> $>$ WITNESSETH $^{\text {EDV }}:$ \\
\hline
\end{tabular} \\
\hline
\end{tabular}




\begin{tabular}{|l|l|l|}
\hline & $\begin{array}{l}\text { Considerando: } \\
\text { Que as Partes celebraram }\end{array}$ & $\begin{array}{l}\text { Whereas } \\
\text { the Parties executed }\end{array}$ \\
\hline
\end{tabular}

O termo witnesseth ocorre somente duas vezes no corpus comparável ing-orig (co112 e co104).

\subsubsection{Whereas}

Como mencionado na seção 2.5 , os recitals de um contrato em inglês freqüentemente consistem em frases iniciadas com a palavra whereas, e no fim (para iniciar o corpo do documento) a expressão NOW, THEREFORE. Este é o caso nos arquivos co 7 e co11.

\begin{tabular}{|c|c|c|}
\hline Arquivo & Original & Tradução \\
\hline col1_us-brN & WHEREAS & CONSIDERANDO QUE $^{\mathrm{L}}$ \\
\hline col1_us-brN & $\begin{array}{l}\text { NOW, THEREFORE, in } \\
\text { consideration of... }\end{array}$ & $<$ omissão $>$ Tendo em vista as... \\
\hline co7_usn-brF (3) & WHEREAS & CONSIDERANDO QUE $^{\mathrm{L}}$ \\
\hline co7_usn-brF & $\begin{array}{l}\text { and now therefore, Company } 1 \text { and } \\
\text { Company } 2 \text { agree as follows }\end{array}$ & $\begin{array}{l}<\text { omissão }>\text { as partes } \\
\text { qualificadas supra têm entre si } \\
\text { justo e acordado o que segue }\end{array}$ \\
\hline
\end{tabular}

O documento co11 contém uma cláusula iniciada pelo termo whereas, e a cláusula seguinte se inicia com now therefore. O documento co7 contém três cláusulas iniciadas pelo termo whereas, e a cláusula após a terceira cláusula com whereas se inicia com now therefore. Whereas é traduzido por "considerando que", uma tradução literal. "NOW, THEREFORE" foi omitido nos dois documentos.

\begin{tabular}{|l|l|l|}
\hline Arquivo & Original & Tradução \\
\hline $\begin{array}{l}\text { co58_br-usD, co57_br-usD, } \\
\text { co56_br-usD, co60_br-usP }\end{array}$ & CONSIDERANDO QUE & WHEREAS $^{\mathrm{L}}$ \\
\hline co53_br-usnF & Considerando: & Whereas $^{\mathrm{L}}$ \\
\hline
\end{tabular}


No sentido tradutório contrário, "considerando que" foi traduzido para whereas no mesmo contexto. Porém, em nenhum caso o tradutor inseriu o tradicional "now, therefore" na primeira cláusula subseqüente. Além desses documentos do corpus br-ing que contêm a expressão "considerando que", 2 documentos do corpus br-orig também contêm essa expressão (co268 e co270), portanto a expressão também ocorre normalmente em documentos jurídicos de língua portuguesa.

\subsubsection{Set his hand}

Este arcaísmo é relativamente raro hoje em dia no contexto do corpo de documentos de direito privado (excluindo anotações posteriores de notários, etc.), e aparece só uma vez no corpus ing-br e uma vez no corpus ing-orig (co124). Ele foi traduzido através de uma equivalência funcional

\begin{tabular}{|l|l|l|}
\hline Arquivo & Original & Tradução \\
\hline dc1_us-brE & $\begin{array}{l}\text { IN WITNESS WHEREOF, the } \\
\text { undersigned hereunto set his hand } \\
\text { this }<\text { date }>\end{array}$ & $\begin{array}{l}\text { Em testemunho do quê, o } \\
\text { abaixo-assinado firmou }\end{array}$ \\
& documento no $<$ data $>$ \\
\hline
\end{tabular}

\subsubsection{Dou Fé}

Já vimos a expressão "dou fé" na seção 6.1.1, na qual foi traduzida por "in witness whereof". As outras traduções dessa expressão no corpus br-ing, porém, foram consistentes.

\begin{tabular}{|c|c|c|}
\hline Arquivo & Original & Tradução \\
\hline pr53_br-usnM & Assim, disse do que dou fé; & $\begin{array}{l}\text { These were the statements made, } \\
\text { which } \underline{\text { I certify }}^{\mathrm{EO}} \text {. }\end{array}$ \\
\hline pr54_br-usnM (2) & do que dou fé. & which I certify $^{\mathrm{EO}}$. \\
\hline
\end{tabular}




\begin{tabular}{|l|l|l|}
\hline pr54_br-usnM & E, de como assim o disse, dou fé. & $\begin{array}{l}\text { And I certify } \\
\text { wo that these were the } \\
\text { words declared by the Appointor. }\end{array}$ \\
\hline
\end{tabular}

Nesses três exemplos, uma equivalência operacional foi utilizada. Documentos norteamericanos são certified.

\subsubsection{Na melhor forma de direito}

Esta expressão ocorre na cláusula padrão "Pelo presente Instrumento e na melhor forma de direito, as Partes..." no início de contratos.

\begin{tabular}{|l|l|l|}
\hline Arquivo & Original & Tradução \\
\hline co51_br-usD & e na melhor forma de direito & and pursuant to law ${ }^{\mathrm{M}}$ \\
\hline co55_br-usnH & e na melhor forma de direito & $\begin{array}{l}\text { and in the due form of the } \\
\text { law }\end{array}$ \\
\hline pr53_br-usnM & e melhor forma de direito & and in the due form of law \\
\hline $\begin{array}{l}\text { co56_br-usD, } \\
\text { co57_br-usD (3); } \\
\text { co58_br-usD (2) }\end{array}$ & e na melhor forma de direito & $\begin{array}{l}\text { and in the best form of the } \\
\text { law }\end{array}$ \\
\hline pr54_br-usnM & e melhor forma de direito & $\begin{array}{l}\text { and pursuant to all applicable } \\
\text { laws }\end{array}$ \\
\hline
\end{tabular}

Nos exemplos acima, a expressão foi traduzida por várias modulações e uma tradução literal. Nenhuma das expressões em inglês foi encontrada no corpus comparável ing-orig. Havia uma ocorrência dessa expressão na tradução do inglês de volta ao português.

\begin{tabular}{|l|l|l|}
\hline Arquivo & Original & Tradução \\
\hline pr9_usn-brB & in its best rightful form & na melhor forma do direito \\
\hline
\end{tabular}


Neste caso, a procuração pr9 em inglês parece ser uma tradução de uma procuração em português (situação D2). A modulação do tradutor pode ter sido uma tentativa de adivinhar o conteúdo desse documento original em português, ou só o uso de uma expressão consagrada em português que se encaixava no contexto.

\subsubsection{Aforesaid}

Aforesaid é um termo arcaico que freqüentemente pode ser substituído por "these". É raramente utilizado fora do universo jurídico, mas ocorre em 3 documentos no corpus comparável ing-orig (c124, c123 e c115) fora os exemplos abaixo do corpus ing-br.

\begin{tabular}{|l|l|l|}
\hline Arquivo & Original & Tradução \\
\hline dc2_uk-brB & aforesaid & acima mencionados $^{\mathrm{L}}$ \\
\hline dc3_uk-brE & aforesaid & descritos acima $^{\mathrm{M}}$ \\
\hline dc4_uk-brE (6) & aforesaid & exposto acima $^{\mathrm{M}}$ \\
\hline dc4_uk-brE, & aforesaid & acima exposto $^{\mathrm{M}}$ \\
\hline pr4_ukn-brM & aforesaid & supracitadas $^{\mathrm{L}}$ \\
\hline
\end{tabular}

Nesses exemplos, é interessante notar que todos os documentos são do Reino Unido. Outro aspecto interessante é a dispersão nas soluções tradutórias, apesar de serem todas quase iguais no nível semântico.

\begin{tabular}{|c|c|c|}
\hline Arquivo & Original & Tradução \\
\hline co53_br-usnF & acima mencionado & aforesaid $^{L}$ \\
\hline co53_br-usnF & acima & aforesaid $^{\mathrm{M}}$ \\
\hline co53_br-usnF & no prazo determinado & 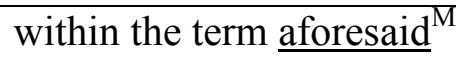 \\
\hline co53_br-usnF & citada & aforesaid $^{\mathrm{M}}$ \\
\hline co54 br-usnF & referido & aforesaid $^{\mathrm{M}}$ \\
\hline
\end{tabular}

O termo aforesaid também foi utilizado como tradução dos mesmos termos vistos acima como sua tradução para português. 


\subsubsection{Bastante procurador}

Temos aqui uma mistura de marcador estilístico e marcador referencial. A tradução de procurador/attorney-in-fact é sem mistérios, mas a tradução do modificador - um marcador estilístico desnecessário para efeitos jurídicos—segue o padrão da tradução de arcaísmos visto acima. Em inglês, também se usa "agent" e "attorney" como sinônimo de attorney-in-fact, mas este último termo é mais específico a procurações. As traduções do corpus br-ing são mostradas abaixo.

\begin{tabular}{|c|c|c|}
\hline Arquivo & Original & Tradução \\
\hline pr51_br-usL & seus bastante procuradores & its true and lawful $^{\text {EDV }}$ attorneys \\
\hline pr52_br-usnM & seu bastante procurador & its true and lawful $^{\text {EDV }}$ Attorney \\
\hline pr54_br-usnM & sua bastante procuradora & his true and lawful ${ }^{\mathrm{EDV}}$ attorney in fact \\
\hline co50_br-usL & seus bastantes procuradores & its $\underline{\text { true and lawful }}^{\mathrm{EDV}}$ attorneys, \\
\hline pr50_br-usL & meu bastante procurador & my Attorney-in-Fact ${ }^{I}$ \\
\hline pr53_br-usnM & seus procuradores & its true and lawful $^{\mathrm{EDV}}$ attorneys in fact \\
\hline
\end{tabular}

Nos primeiros quatro exemplos, bastante foi traduzido por seu equivalente discursivo "true and lawful". No quinto exemplo, bastante foi implicitado (e o termo mais específico a procurações - attorney-in-fact-foi utilizado). No quinto exemplo, "true and lawful" foi inserido mesmo sem haver "bastante" no original, devido à forte presença do equivalente discursivo no universo da tradução.

\begin{tabular}{|c|c|c|}
\hline Arquivo & Original & Tradução \\
\hline $\begin{array}{l}\text { pr1_usn-brM } \\
\text { (2) }\end{array}$ & attorney-in-fact & bastante $^{\mathrm{EDV}}$ procurador \\
\hline pr2_us-brM & as my Attorney-in-Fact ("Agent"). & $\begin{array}{l}\text { como minha bastante }{ }^{\text {EDV }} \text { procuradora } \\
\text {.... ("Procuradora") }\end{array}$ \\
\hline co2_us-brG & attorney-in-fact & bastante $^{\mathrm{EDV}}$ procurador \\
\hline
\end{tabular}


Nesses três exemplos, o termo bastante foi acrescido, como se o termo "bastante procurador" fosse a tradução de attorney-in-fact.

\begin{tabular}{|c|c|c|}
\hline Arquivo & Original & Tradução \\
\hline pr5_usn-brE & its true and lawful Attorney & seu bastante ${ }^{\text {EDV }}$ procurador Person2 \\
\hline $\begin{array}{l}\text { pr4_ukn-brM } \\
\text { (2) }\end{array}$ & its true and lawful attorney-in-fact & $\begin{array}{l}\text { seus verdadeiros e legitimos } \\
\text { bastantes }^{\mathrm{EDV}} \text { procuradores }\end{array}$ \\
\hline pr1_usn-brM & the true and lawful Attorney-in-Fact & $\begin{array}{l}\text { como verdadeiro e legítimo } \\
\text { bastante }^{\mathrm{EDV}} \text { procurador }\end{array}$ \\
\hline
\end{tabular}

O primeiro exemplo acima traduz "true and lawful" por seu equivalente discursivo, mas o segundo e terceiro exemplos utilizam essa equivalência discursiva mais uma tradução literal. Esta solução é particularmente inesperada considerando que o tradutor "M" utilizou somente a equivalência discursiva (sem a tradução literal) ao traduzir para o inglês nos documentos pr52, pr53 e pr54 acima.

\subsubsection{Resumo das freqüências de ocorrência e conclusões}

Em resumo, a figura 6.1 mostra a freqüência de ocorrência de soluções representando cada grau de ocorrência (veja o apêndice para os dados brutos completos) para os exemplos da seção 6.1. 


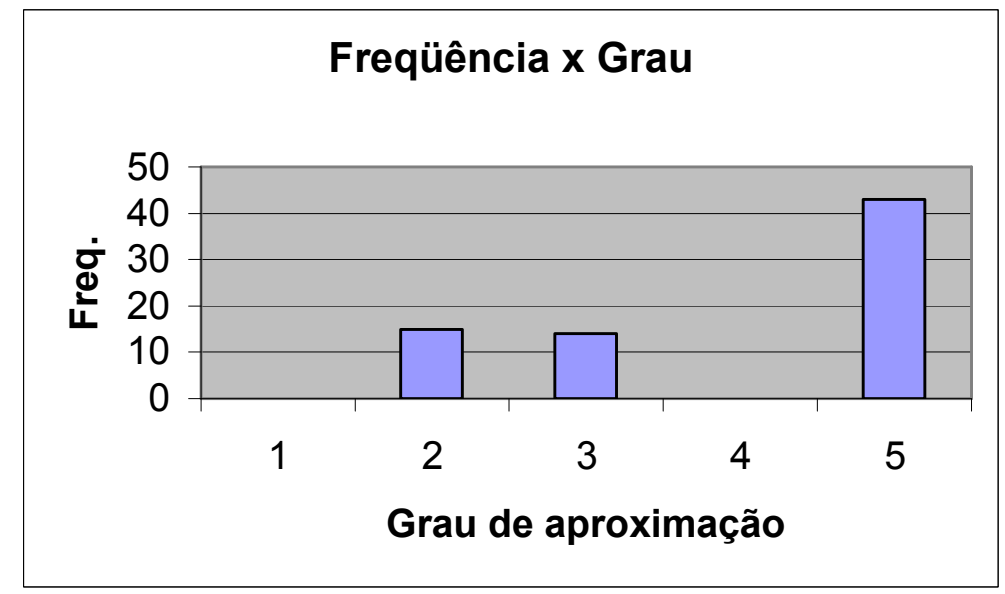

Figura 6.1 - Freqüência de ocorrência de cada grau de aproximação — arcaísmos

Como esperado para marcadores estilísticos, não há nenhuma ocorrência de soluções de graus 1 e 4, e há mais ocorrências de soluções do grau 5 do que de soluções de grau 2 e grau 3 juntas.

\begin{tabular}{|l|c|c|c|c|c|}
\hline Modalidade & Grau 1 & Grau 2 & Grau 3 & Grau 4 & Grau 5 \\
\hline D & - & 5 & - & - & - \\
\hline EDV & - & 1 & - & - & 27 \\
\hline EF & - & - & 1 & - & - \\
\hline EO & - & - & 3 & - & - \\
\hline I & - & - & - & - & 1 \\
\hline L & - & - & 3 & - & 8 \\
\hline M & - & 6 & 7 & - & 5 \\
\hline O & - & - & - & - & 2 \\
\hline & & 2 EDV-L & & - & - \\
\hline outro & - & 1 EDV-ER & - & $\mathbf{0}$ & $\mathbf{4 3}$ \\
\hline totais & $\mathbf{0}$ & $\mathbf{1 5}$ & $\mathbf{1 4}$ & & \\
\hline
\end{tabular}

Tabela 6.1 - Freqüência de ocorrência de modalidade por grau de aproximação — arcaísmos 
Como vimos nas análises qualitativas, há uma forte tendência para a equivalência discursiva, especialmente quando a forma (no outro idioma) é muito conhecida.

\begin{tabular}{|c|c|c|c|c|}
\hline Grau & $\begin{array}{c}\text { ing-br } \\
\text { ocorrência }\end{array}$ & ing-br \% & $\begin{array}{c}\text { br-ing } \\
\text { ocorrência }\end{array}$ & br-ing \% \\
\hline 1 & 0 & $0 \%$ & 0 & $0 \%$ \\
\hline 2 & 7 & $26 \%$ & 8 & $18 \%$ \\
\hline 3 & 6 & $22 \%$ & 8 & $18 \%$ \\
\hline 4 & 0 & $0 \%$ & 0 & $0 \%$ \\
\hline 5 & 14 & $52 \%$ & 29 & $64 \%$ \\
\hline totais & $\mathbf{2 7}$ & $\mathbf{1 0 0 \%}$ & $\mathbf{4 5}$ & $\mathbf{6 3 \%}$ \\
\hline
\end{tabular}

Tabela 6.2 - Freqüência de ocorrência por grau de aproximação — arcaísmos — por corpus paralelo

Observe que há uma maior tentativa de localização (principalmente através da equivalência descursiva) nos documentos do corpus br-ing. Como o corpus br-ing é menor (em termos de número de palavras), o número absoluto de exemplos de grau 5 (29 comparado com 14) é mais impressionante ainda.

\begin{tabular}{|c|c|c|}
\hline Grau & ing-br & br-ing \\
\hline 2 & $85,7 \%$ jur. $14,3 \%$ não & $12,5 \%$ jur. $87,5 \%$ não \\
\hline 5 & $35,7 \%$ jur. $64,3 \%$ não & $37,9 \%$ jur. $62,1 \%$ não \\
\hline
\end{tabular}

Tabela 6.3 - Freqüência de ocorrência para graus de aproximação 2 e 5 - arcaísmos - por corpus paralelo e por traduções juramentadas ou não

Olhando os dados para os graus 2 e 5 em mais detalhes, fiz os cálculos parar ver quantos dos exemplos dos graus 2 e 5 eram de traduções juramentadas e quantos eram de traduções não juramentadas. Os resultados para o corpus ing-br foram talvez previsíveis, com $85,7 \%$ dos 
exemplos de grau 2 retirados de traduções juramentadas, e só $35,7 \%$ dos exemplos de grau 5 retirados dessas traduções, pois espera-se menos localização em uma tradução juramentada. No corpus br-ing, enquanto os exemplos de grau 5 também seguiram este raciocínio $(62,1 \%$ dos exemplos de grau 5, representando localização, eram de traduções não juramentadas), os exemplos de grau 2 foram o contrário, com a maioria sendo de traduções não juramentadas.

Olhando estes 8 exemplos (grau 2, corpus br-ing), 5 foram soluções para a tradução de "na melhor forma de direito".

\subsection{Binômios tautológicos}

Binômios tautológicos contêm dois termos sinônimos (da mesma categoria sintática) ligados por "e" ou por "ou". Às vezes fazem parte de um trinômio ou lista até maior de sinônimos. Segundo Garner (1995):

"Amplification by synonym has long been a part of the English language, and especially a part of the language of the law. In the English Renaissance, this habit was a common figure of speech called synonymia. It is often supposed that the purpose of these paired or strung-along synonyms was etymological, that is, that writers in the Middle Ages and Renaissance would pair a French or Latinate term with an Anglo-Saxon approximation as a gloss on the foreign word. Thus, we have, as survivals in legal language, acknowledge and confess (Old English and Old French), act and deed (Latin and Old English), and goods and chattels (Old English and Old French).

The philologist George Phillip Krapp argued against this explanation. He saw the purpose of this mannerism as "rhetorical or oratorical rather than etymological." George P. Krapp, Modern English: Its Growth and Present Use 251 (1909). He pointed out that such doubling occurred abundantly in Old English, when no substantial foreign element existed in the language, and that it often occurs in later 
writings without regard for etymology. Although Krapp was undoubtedly correct to emphasize the rhetorical importance of doubling, he was wrong to assume that the figure did not take on a utilitarian significance as well in middle and early Modern English. The purpose of doubling was dual: to give rhetorical weight and balance to the phrase, and to maximize the understanding of readers or listeners.

Still another explanation has emerged for the particular fondness that lawyers have for this stylistic quirk. It is a cynical one: "This multiplication of useless expressions probably owed its origin to the want of knowledge of the true meaning and due application of each word, and a consequent apprehension, that if one word alone were used, a wrong one might be adopted and the right one omitted; and to this something must be added for carelessness and the general disposition of the profession to seek safety in verbosity rather than in discrimination of language." Charles Davidson, Precedents and Forms in Conveyancing 67 (3rd ed. 1860)

Os tradutores que contribuíram as traduções deste estudo não são advogados (exceto em um caso) e esperaríamos ver traduções literais na maioria dos casos, sem omissão de um dos sinônimos.

\subsubsection{Power and authority}

Um binômio comum em inglês, mas sem correspondente no português, é "power and authority".

\begin{tabular}{|l|l|l|}
\hline Arquivo & Original & Tradução \\
\hline $\begin{array}{l}\text { dc2_uk-brB (4), } \\
\text { dc4_uk-brB (4) }\end{array}$ & has such powers and authorities & terá os poderes e a autoridade $^{\mathrm{L}}$ \\
\hline co6_us-brA & full legal power and authority & poder e autoridade $^{\mathrm{L}}$ legal plena \\
\hline pr1_usn-brM & with the powers and authorities & com os poderes e a competência $^{\mathrm{L}}$ \\
\hline
\end{tabular}




\begin{tabular}{|l|l|l|}
\hline pr2_us-brM & $\begin{array}{l}\text { My Agent shall have full power and } \\
\text { authority }\end{array}$ & $\begin{array}{l}\text { Minha Procuradora terá plenos } \\
\text { poderes e plena competência }\end{array}$ \\
\hline co2_us-brG & full power and authority & plenos poderes e competência \\
\hline
\end{tabular}

Nestes exemplos acima, todas as traduções foram literais de uma maneira ou outra. Esta foi a solução mais comum.

\begin{tabular}{|l|l|l|}
\hline Arquivo & Original & Tradução \\
\hline pr2_us-brM & Any power or authority & Todo poder ou $^{\mathrm{L}}$ toda autorização $^{\mathrm{M}}$ \\
\hline co2_us-brG & full power and authority & plenos poderes $^{\mathrm{L}}$ para \\
\hline
\end{tabular}

Nestes dois exemplos, as soluções (pelos mesmos tradutores $\mathrm{M}$ e $\mathrm{G}$ acima) incluem uma modulação e uma implicitação. "Plenos poderes" é uma expressão natural em português, e ocorre duas vezes no corpus comparável br-orig (pr205 e pr204).

No sentido tradutório contrário, nenhuma ocorrência de poder(es) no corpus br-ing foi traduzida com um binômio, e não houve nenhuma ocorrência do binômio "poder(es) e autoridade" no corpus br-ing

\subsubsection{Force and Effect}

Garner (1995, p. 366) diz o seguinte sobre este binômio tautológico:

"force and effect is a doublet that has become part of the legal idiom in the phrases in full force and effect and of no force or effect, neither of which is a term of art. Either synonym would suffice just as well as the doublet; but the emphasis gained by force and effect may justify use of the phrase, more likely in drafting (contracts and statutes) than in judicial opinions." 


\begin{tabular}{|l|l|l|}
\hline Arquivo & Original & Tradução \\
\hline co7_usn_brF & This Agreement shall enter into & Este Termo entrará em vigor \\
& force and effect upon signature & todos os efeitos quando de sua \\
& and shall remain into force and \\
& effect for a period of 5 years & assinatura pelas Partes e permanecerá \\
vigente $^{\mathrm{I}-\mathrm{L}}$ pelo prazo de 5 (cinco) anos
\end{tabular}

Nesse exemplo, o binômio force and effect foi traduzido através de implicitações diferentes na primeira e segunda ocorrências.

No sentido tradutório contrário, para comparação, vigor foi traduzido literalmente por force ou por effect, mas nunca pelo binômio force and effect:

\begin{tabular}{|l|l|l|}
\hline Arquivo & Original & Tradução \\
\hline $\begin{array}{l}\text { pr52_br-usnM, dc50_br-usL, co59_br-usL, co51_br-usD } \\
\text { (2), co60_br-usP (2), co61_br-usQ }\end{array}$ & vigor & force \\
\hline $\begin{array}{l}\text { dc52_br-usD, dc51_br-usL, dc50_br-usL, co59_br-usL, } \\
\text { co50_br-usL, dc53_br-usnE }\end{array}$ & vigor & effect \\
\hline
\end{tabular}

Também houve algumas outras soluções (também apresentados para fins de comparação):

\begin{tabular}{|c|c|c|}
\hline Arquivo & Original & Tradução \\
\hline co59_br-usL & legislação em vigor aplicável & applicable and effective $^{\mathrm{L}}$ laws \\
\hline co51_br-usD & $\begin{array}{l}\text { a presente locação continuará em } \\
\underline{\text { vigor }}\end{array}$ & $\begin{array}{l}\text { this present lease shall remain } \\
\text { effective }^{\mathrm{L}}\end{array}$ \\
\hline co51_br-usD & $\begin{array}{l}\text { a atualização monetária do aluguel } \\
\text { permanecerá em pleno vigor }\end{array}$ & $\begin{array}{l}\text { the rent shall continue to be corrected } \\
\text { monetarily <implicitação }>\end{array}$ \\
\hline
\end{tabular}

As duas primeiras soluções utilizam uma tradução literal, e a terceira omite o termo completamente através de uma implicitação. 
Dois binômios semelhantes foram traduzidos através de tradução literal dos dois termos componentes:

\begin{tabular}{|l|l|l|}
\hline Arquivo & Original & Tradução \\
\hline $\begin{array}{l}\text { dc4_uk-brE, } \\
\text { dc2_uk-brB }\end{array}$ & force and validity & força e validade $^{\mathrm{L}}$ \\
\hline co52_br-usK & nenhum efeito e/ou validade & no longer effective and/or valid \\
\hline
\end{tabular}

A expressão "força e validade" não ocorre no corpus comparável br-orig.

\subsubsection{By and between}

Esta coordenação preposicional ainda se vê em documentos de língua inglesa. Havia 9 ocorrências de by and between no corpus ing-orig, nos arquivos co120, co112, co124, co123, co119, co116, co114 co106 e co102. Segundo Garner (1995, p. 125) "between alone suffices"

\begin{tabular}{|l|l|l|}
\hline Arquivo & Original & Tradução \\
\hline co7_usn-brF & $\begin{array}{l}\text { This Agreement is made this 0 day } \\
\text { of XX 0000 by and between }\end{array}$ & $\begin{array}{l}\text { Firmam o presente Termo, aos 0 dias de } \\
\text { XX de 0000 as Partes <implicitação> }\end{array}$ \\
\hline
\end{tabular}

$\mathrm{Na}$ única ocorrência desse binômio no corpus ing-br, o tradutor omitiu os termos completamente através de uma implicitação.

\begin{tabular}{|l|l|l|}
\hline Arquivo & Original & Tradução \\
\hline dc52_br-usD & estipulado entre as sócias & $\begin{array}{l}\text { agreed to } \underline{\text { by and between }} \\
\text { quotaholders }\end{array}$ \\
\hline co58_br-usD & celebrado $\underline{\text { entre } \text { as partes }}$ & $\begin{array}{l}\text { entered into } \underline{\text { by and between }} \\
\text { parties }\end{array}$ \\
\hline
\end{tabular}




\begin{tabular}{|l|l|l|}
\hline co56_br-usD (2) & celebrado entre & entered into by and between $^{\text {EDV }}$ \\
\hline co53_br-usnF & de um lado ... e, de outro lado & by and between \\
\hline
\end{tabular}

No outro sentido tradutório, a maioria das ocorrências de "entre" foi traduzida literalmente. Porém, os quatro exemplos acima (por dois tradutores diferentes) mostram a utilização de equivalência discursiva.

\subsubsection{Termos e condições}

Segundo Garner (1995, p. 872)

"terms and conditions. This phrase is among the most common redundancies in legal drafting... terms is sufficient."

As traduções, porém, são quase todas literais.

\begin{tabular}{|c|c|c|}
\hline Arquivo & Original & Tradução \\
\hline $\begin{array}{l}\text { co2_us-brG (3), co4_us-brJ (2), } \\
\text { co5_us-brJ, co6_us-brA (4), co7_usn- } \\
\text { brF, co11_us-brN (2), dc2_uk-brB (2), } \\
\text { dc3_uk-brE, }\end{array}$ & $\begin{array}{l}\text { terms and } \\
\text { conditions }\end{array}$ & $\begin{array}{l}\text { termos e condições } \\
\text { (e variações com artigos } \\
\text { definidos, p.ex. os termos e as } \\
\text { condições) }\end{array}$ \\
\hline dc4_uk-brE & $\begin{array}{l}\text { on such terms and } \\
\underline{\text { conditions }}\end{array}$ & nas condições e termos $^{\mathrm{L}}$ \\
\hline
\end{tabular}

A maioria é literal, com algumas variações nos artigos devido ao contexto, e em um caso a ordem dos termos dentro do binômio foi invertida.

\begin{tabular}{|l|l|l|}
\hline Arquivo & Original & Tradução \\
\hline co7_usn-brF & $\begin{array}{l}\text { in accordance with the terms and } \\
\text { conditions of this Agreement, }\end{array}$ & $\begin{array}{l}\text { em estrita conformidade com o } \\
\text { disposto }^{\mathrm{M}} \text { neste Termo, }\end{array}$ \\
\hline dc3_uk-brE & To acquire and undertake on any & Adquirir e empreender sob \\
\hline
\end{tabular}




\begin{tabular}{|l|l|l|}
\hline & $\underline{\text { terms } \text { and subject to any conditions }}$ & $\begin{array}{l}\text { quaisquer } \text { condições }^{\mathrm{L}} \text { e sujeito } \\
\text { a quaisquer condiçõ es }^{\mathrm{L}}\end{array}$ \\
\hline
\end{tabular}

Nestes dois exemplos, há duas variações. Os dois elementos do binômio foram substituídos por um termo menos concreto, talvez devido à decisão posterior de utilizar "Termo" como tradução de Agreement ao longo do contrato. No segundo exemplo, o tradutor utilizou condições para traduzir tanto terms quanto conditions, repetindo o termo dentro da mesma frase.

Nos contextos nos quais terms e conditions aparecem como parte de uma lista de 3 ou mais elementos (documentos pr1 e co7), foram traduzidos de maneira literal. No sentido tradutório contrário, todas as ocorrências de "termos e condições" foram traduzidas pelo binômio "terms and conditions" sem exceção.

\subsubsection{Livre e desimpedido}

Há equivalentes para os binômio "livre e desimpedido" e "livre e desembaraçado" em inglês, que permitem tradução literal.

\begin{tabular}{|c|c|c|}
\hline Arquivo & Original & Tradução \\
\hline $\operatorname{co5} 1$ & $\begin{array}{l}\text { em bom estado de conservação, livre } \\
\underline{\text { e desimpedido de coisas e pessoas }}\end{array}$ & $\begin{array}{l}\text { in good condition, free and } \\
\text { unencumbered }^{\mathrm{L}} \text { of things or people, }\end{array}$ \\
\hline co59_br-usL & $\begin{array}{l}\text { de execução dos trabalhos, } \\
\text { deixando-o livre e desimpedido de } \\
\text { pessoas e coisas, }\end{array}$ & $\begin{array}{l}\text { where work is performed, leaving it } \\
\text { vacant }{ }^{\mathrm{I}} \text { of people and moveable } \\
\text { property, }\end{array}$ \\
\hline co50_br-usL & $\begin{array}{l}\text { até a real e efetiva entrega do imóvel } \\
\text { pelos LOCADORES à } \\
\text { LOCATÁRIA livre de pessoas e } \\
\text { coisas. }\end{array}$ & $\begin{array}{l}\text { as the real and effective transfer of } \\
\text { possession of the property to the } \\
\text { TENANT by the OWNERS, free }{ }^{\mathrm{L}} \text { of } \\
\text { people and objects. }\end{array}$ \\
\hline
\end{tabular}


Nos primeiros dois exemplos acima, o binômio foi traduzido por um binômio no primeiro caso e por um único termo no segundo exemplo. O contexto do terceiro exemplo é o mesmo mas não há binômio nem no original nem na tradução.

\begin{tabular}{|l|l|l|}
\hline Arquivo & Original & Tradução \\
\hline co3_us-brG & shall be made free and clear of & serão livres e isentos \\
\hline co3_us-brG e de \\
\hline co8_us-brF & $\underline{\text { free and clear of, and without deduction }}$ & $\begin{array}{l}\underline{\text { livres e desembaraçados }}^{\mathrm{L}} \mathrm{e} \\
\text { sem dedução de quaisquer }\end{array}$ \\
\hline
\end{tabular}

Nos primeiros dois exemplos, ambos do documento co3, o binômio foi traduzido por outro binômio (mas, inesperadamente, não o mesmo). No terceiro exemplo, a palavra free foi traduzida por um binômio consagrado, uma equivalência discursiva.

\subsubsection{Resumo de freqüências de ocorrência e conclusões}

Em resumo, a figura 6.2 mostra a freqüência de ocorrência de soluções representando cada grau de ocorrência (veja o apêndice para os dados brutos completos) para os exemplos da seção 6.2.

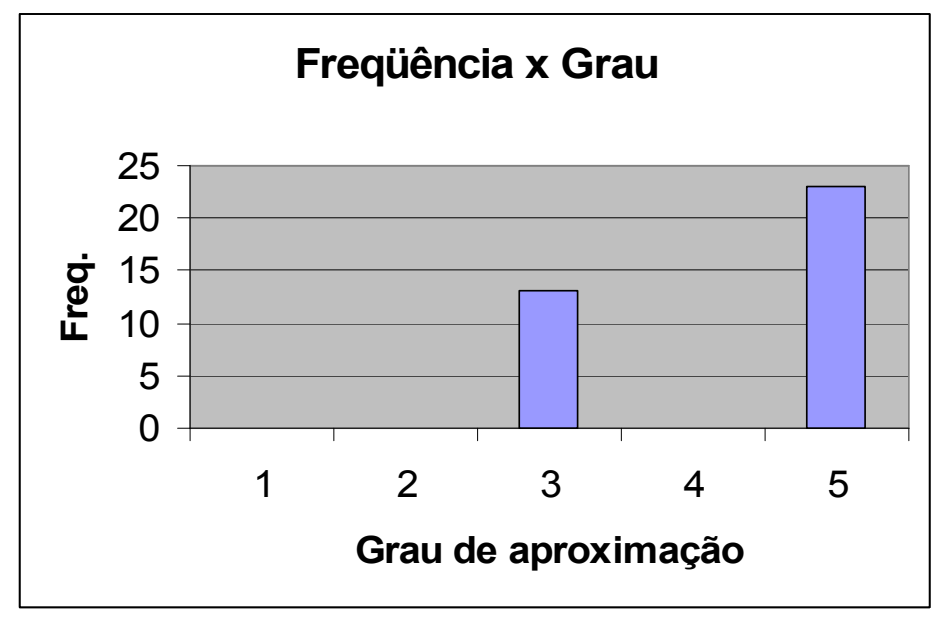

Figura 6.2 - Freqüencia de ocorrência de cada grau de aproximação - binômios tautológicos 
As traduções se encaixaram ou no grau 3 ou no grau 5, com o grau dependente às vezes da feliz coincidência de uma tradução literal de um idioma para outro soar natural também na língua de chegada.

\begin{tabular}{|l|c|c|c|c|c|}
\hline Modalidade & Grau 1 & Grau 2 & Grau 3 & Grau 4 & Grau 5 \\
\hline EDV & - & - & - & - & 5 \\
\hline I & - & - & 1 & - & 2 \\
\hline L & - & - & 12 & - & 13 \\
\hline M & - & - & - & - & 1 \\
\hline outro & - & - & - & - & 2 \\
\hline totais & 0 & 0 & 13 & 0 & 23 \\
\hline
\end{tabular}

Tabela 6.4 - Freqüencia de ocorrência de modalidade por grau de aproximação — binômios tautológicos

Várias modalidades foram empregadas nesta seção para alcançar um texto localizado para a língua e o país de chegada. Observe que a equivalência discursiva foi empregada apenas 5 vezes.

\subsection{Binômios não tautológicos}

Este tipo de binômio às vezes pode ser substituído por um único termo no texto original, mas as traduções são principalmente literais, exceto nos casos onde existe um equivalente discursivo bem conhecido.

\subsubsection{Residente e domiciliado}

As definições destes dois termos no Dicionário Jurídico de Maria Helena Diniz são: 
DOMICILIADO. 1. Direito civil. Aquele que se domiciliou, possuindo uma sede para seus negócios ou atividades. 2. Local de caráter definitivo onde a pessoa física ou jurídica tem a sede de seus negócios. (Diniz, 2005; v. 2, p. 274)

RESIDENTE. 1. Direito civil. Diz-se do que mora em certo local. 2. Direito internacional público. a) Ministro residente enviado por um governo para agir, em caráter permanente, junto a outro, estrangeiro. Esse agente diplomático, na sua classe, ocupa o terceiro lugar, sendo o segundo do ministro plenipotenciário e enviado extraordinário, e o primeiro, do embaixador; b) título de determinados funcionários coloniais (Laudelino Freire). 3. Direito administrativo. Diz-se do funcionário que reside no local onde exerce suas funções públicas. (Diniz, 2005; v. 4, p. 193)

Só a primeira definição de residente se aplica ao presente contexto.

As definições dos dois termos no Black's Law Dictionary são:

RESIDENT: (n) A person who has residence in a particular place. A resident is not necessarily either a citizen or a domiciliary. (Garner, 1999)

DOMICILIARY: (n) A person who resides in a particular place with the intention of making it a principal place of abode; one who is domiciled in a particular jurisdiction. (Garner, 1999)

Podemos ver que a definição de resident se assemelha à de residente e a definição de domiciliado se assemelha à de domiciliary. Observe, porém, que residente/domiciliado são adjetivos e resident/domiciliary são substantivos. Isso é uma preferência de cada dicionário para uma forma ou outra, mas presume-se que os cognatos têm o mesmo significado, pois não há verbetes separados para as formas adjetivais. O adjetivo é também utilizado nos textos em inglês. 
Garner também fala (em seu Dictionary of Modern Legal Usage) justamente sobre este binômio:

DOMICILE AND RESIDENCE: The two words are often confused as synonymous. They are not: "Residence comprehends no more than a fixed abode where one actually lives for the time being. It is distinguished from domicile in that domicile is the place where a person intends eventually to return and remain." (Garner, 1995)

Procurei as ocorrências do binômio residente e domiciliado e dos dois termos individuais no corpus br-ing. Considerei as formas masculina/feminina/plural iguais, por não ser importante essa diferença devida somente à concordância.

\begin{tabular}{|l|l|l|}
\hline Arquivo & Original & Tradução \\
\hline $\begin{array}{l}\text { pr51_br-usL, pr53_br-usnM, pr54_br- } \\
\text { usnM (2), co50_br-usL (5), } \\
\text { c54n,dc51_br-usL, dc52_br-usD (2), } \\
\text { dc53_br-usnE, dc54_br-usnE (3) }\end{array}$ & residente(s) & resident and domiciled \\
\hline $\begin{array}{l}\text { pr53_br-usnM (3), co55_br-usnH (1), } \\
\text { dc52_br-usD (1), dc53_br-usnE (2) }\end{array}$ & domiciliado & \\
\hline pr50_br-usL (2), dc54_br-usnE & residente & domiciled $^{\mathrm{L}}$ \\
\hline
\end{tabular}

Na maioria dos casos, as traduções são literais, tanto do binômio quanto dos termos quando ocorrem individualmente no original.

\begin{tabular}{|l|l|l|}
\hline Arquivo & Original & Tradução \\
\hline pr52_br-usnM & domiciliado e residente & resident and domiciled $^{\mathrm{L}}$ \\
\hline
\end{tabular}


Neste exemplo, o tradutor mudou a ordem dos elementos do binômio para a ordem consagrada (a ordem comum). A solução é classificada como tradução literal, pois a definição desta modalidade neste estudo inclui transposição de ordem.

\begin{tabular}{|l|l|l|}
\hline Arquivo & Original & Tradução \\
\hline dc51_br-usL & domiciliado & resident and domiciled $^{\text {EDV }}$ \\
\hline
\end{tabular}

Este é mais um exemplo de padronização na tradução, com a inserção de uma palavra omissa no original (o original não seguiu o padrão, mas a tradução sim).

No estudo de Aubert (2005b), os resultados foram semelhantes. A tradução de residente e domiciliado foi:

\begin{tabular}{|c|l|}
\hline $\begin{array}{c}\text { Ocorrências } \\
\text { (tradutores diferentes) }\end{array}$ & \multicolumn{1}{c|}{ Tradução } \\
\hline 7 & resident and domiciled \\
\hline 2 & residing and domiciled \\
\hline 1 & residing \\
\hline
\end{tabular}

Observe que a única tradução não literal foi uma omissão no estudo de Aubert, enquanto no corpus br-ing havia uma transposição de ordem e uma equivalência discursiva.

Procurei as ocorrências do binômio resident and domiciled no corpus ing-br.

\begin{tabular}{|ll|l|l|}
\hline Arquivo & Original & Tradução \\
\hline pr3_us-brB (2), & resident and domiciled & residente e domiciliado(a $)^{\mathrm{L}}$ \\
pr4_ukn-brM $\quad(2)$, & & \\
pr6_ukn-brE, & & \\
pr8_ukn-brH & & \\
\hline
\end{tabular}




\begin{tabular}{|l|l|l|}
\hline pr5_usn-brE & resident and domiciled & domiciliado e residente $^{\mathrm{L}}$ \\
\hline p7_ukn-brnL & resident and living & residente e domiciliado $^{\mathrm{L}}$ \\
\hline
\end{tabular}

O segundo exemplo é interessante por traduzir o binômio comum por um binômio com a ordem invertida (comparada tanto com o original quanto com a ordem consagrada no idioma de chegada). O terceiro exemplo padroniza o que parece ter sido uma tradução para o registro incorreto em inglês na confecção do documento original.

Um aspecto que marca alguns dos textos como feitos por indivíduos cuja língua de domínio mais ativo não é o inglês é o uso do gerúndio, com residing em vez de resident nos textos traduzidos estudados por Aubert (2005b) e living no documento original p7_ukn-brnL. Uma busca nesses dois gerúndios no corpus ing-orig (de documentos originalmente escritos em inglês) não encontra nenhuma ocorrência.

\subsubsection{Nomeio e constituo}

Nomear e constituir é um outro binômio de elementos não sinônimos. Segundo o Dicionário de verbos jurídicos (Henriques, 1999), nomear significa indicar, designar, investir e escolher; e constituir significa atribuir poderes, dar poderes.

Uma busca para "nomear" e para "constituir" no corpus br-ing encontrou as seguintes ocorrências:

\begin{tabular}{|c|c|c|}
\hline Arquivo & Original & Tradução \\
\hline pr53_br-usnM & $\begin{array}{l}\text { nomeia e constitui } \\
\text { procuradores }\end{array}$ & $\begin{array}{l}\text { appoints }^{\mathrm{EDV}} \text { its true and lawful } \\
\text { attorneys in fact }\end{array}$ \\
\hline pr54_br-usnM & $\begin{array}{l}\text { nomeia e constitui sua bastante } \\
\text { procuradora }\end{array}$ & $\begin{array}{l}\text { appoints }^{\text {EDV }} \text { his true and } \\
\text { lawful attorney in fact }\end{array}$ \\
\hline pr51_br-usL & $\begin{array}{l}\text { nomeia e constitui seus bastante } \\
\text { procuradores }\end{array}$ & $\begin{array}{l}\text { appoints }^{\text {EDV }} \text { as its true and } \\
\text { lawful attorneys }\end{array}$ \\
\hline
\end{tabular}




\begin{tabular}{|l|l|l|}
\hline co52_br-usK & nomeia o representante & appoints $^{\mathrm{L}}$ the Agent \\
\hline pr52_br-usnM & $\begin{array}{l}\text { nomeia e constitui seu bastante } \\
\text { procurador }\end{array}$ & appoints and constitutes $^{\mathrm{L}} \ldots$ \\
\hline pr50_br-usL & $\begin{array}{l}\text { nomeio e constituo meu bastante } \\
\text { procurador }\end{array}$ & nominate and establish $^{\mathrm{L}} \ldots$ \\
\hline
\end{tabular}

Observe que a única tradução de constituir como constitute foi por um tradutor cuja língua de domínio mais ativo não era a língua de chegada. Constitute não está presente no Black's Law Dictionary, e Garner (1995, p. 208) declara que constitute é freqüentemente utilizado no lugar de make, desnecessariamente.

Em resumo:

\begin{tabular}{|c|l|l|}
\hline Ocorrências & Original & Tradução \\
\hline 3 & nomear e constituir & appoint $^{\mathrm{EDV}}$ \\
\hline 1 & nomear e constituir & appoints and constitutes $^{\mathrm{L}}$ \\
\hline 1 & nomear e constituir & nominate and establish $^{\mathrm{L}}$ \\
\hline 1 & nomear & appoint $^{\mathrm{L}}$ \\
\hline
\end{tabular}

Ou 3 equivalências discursivas e 3 traduções literais.

Uma busca para appoint, constitute e grant nos documentos originais no corpus br-ing e em "nomear" e "constituir" nas traduções do mesmo corpus encontrou as seguintes ocorrências:

\begin{tabular}{|l|l|l|}
\hline Arquivo & Original & Tradução \\
\hline co2_us-brG & $\begin{array}{l}\text { The Undersigned hereby appoints the } \\
\text { Pledgee }\end{array}$ & $\begin{array}{l}\text { Pelo presente instrumento, o } \\
\text { Signatário nomeia e constitui } \\
\text { CDV o } \\
\text { Credor Pignoratício }\end{array}$ \\
\hline pr1_usn-brM & HEREBY MAKES CONSTITUTES & NOMEIA E CONSTITUI \\
\hline
\end{tabular}




\begin{tabular}{|c|c|c|}
\hline & AND APPOINTS: & \\
\hline pr2_us-brM & $\begin{array}{l}\text { hereby appoint Person } 2 . . . \text { as my } \\
\text { Attorney-in-Fact ("Agent"). }\end{array}$ & $\begin{array}{l}\text { PELO PRESENTE } \\
\text { INSTRUMENTO, NOMEIO }{ }^{\mathrm{L}} \text { como } \\
\text { minha bastante procuradora ... }\end{array}$ \\
\hline dc4_uk-brE & of the member appointing the proxy. & do sócio que nomeia ${ }^{L}$ o pro \\
\hline dc4_uk-brE & $\begin{array}{l}\text { HEREBY APPOINT X ... to be } \\
\text { my/our proxy to vote for me/us at the } \\
\text { meeting of members... }\end{array}$ & $\begin{array}{l}\text { POR MEIO DESTE } \\
\text { INSTRUMENTO NOMEIO } \\
\text { meu/nosso bastante procurador }\end{array}$ \\
\hline pr4_ukn-brM & $\begin{array}{l}\text { hereby appoints and constitutes as its } \\
\text { true and lawful attorneys-in-fact }\end{array}$ & $\begin{array}{l}\text { NOMEIA E CONSTITUI }{ }^{\mathrm{L}} \text { como } \\
\text { seus verdadeiros e legítimos } \\
\text { bastantes procuradores }\end{array}$ \\
\hline pr5_usn-brE & $\begin{array}{l}\text { HEREBY appoints and constitutes } \\
\text { Mr. Person } 2 \ldots \text { as its true and lawful } \\
\text { Attorney }\end{array}$ & $\begin{array}{l}\text { nomeia e constitui }{ }^{\mathrm{L}} \text { seu bastante } \\
\text { procurador ... }\end{array}$ \\
\hline $\begin{array}{l}\text { pr7_ukn- } \\
\text { brnL }\end{array}$ & $\begin{array}{l}\text { names and empowers as its proxy, } \\
\text { Person1 }\end{array}$ & nomeia e constitui $^{\text {EDV }}$ Pessoa 1 \\
\hline pr9_usn-brB & $\begin{array}{l}\text { credits, grants and appointments as } \\
\text { proxies the following individuals: }\end{array}$ & $\begin{array}{l}\underline{\text { indica, nomeia e constitui }}^{\mathrm{M}} \\
\text { procuradores as seguintes pessoas }\end{array}$ \\
\hline
\end{tabular}

As procurações no corpus ing-br não devem ser consideradas bons exemplos de uso do idioma inglês devido ao seu estilo e formato claramente brasileiros, e seu inglês questionável.

Em resumo (pelo infinitivo):

\begin{tabular}{|c|l|l|}
\hline Ocorrências & Original & Tradução \\
\hline 3 & appoint & nomear $^{\mathrm{L}}$ \\
\hline 2 & appoint and constitute & nomear e constituir $^{\mathrm{L}}$ \\
\hline 1 & appoint & nomear e constituir $^{\mathrm{EDV}}$ \\
\hline 1 & name and empower & nomear e constituir $^{\mathrm{EDV}}$ \\
\hline
\end{tabular}




\begin{tabular}{|l|l|l|}
\hline 1 & make, constitute and appoint & nomear e constituir $^{\text {EDV }}$ \\
\hline 1 & credit, grant and appoint & indicar, nomear e constituir $^{\mathrm{M}}$ \\
\hline
\end{tabular}

Vemos nessas traduções para o português uma forte tendência à normalização. Todos os binômios nesse contexto (de procuração ou semelhante) e até um trinômio e um termo simples são traduzidos pelo binômio "nomear e constituir". Em outros 3 casos, appoint vem traduzido simplesmente por "nomear".

\subsubsection{Jointly and severally}

A expressão consagrada jointly and severally é definida no Black's Law Dictionary assim:

joint and several liability. Liability that may be apportioned either among two or more parties or to only one or a few select members of the group, at the adversary's discretion. Thus, each liable party is individually responsible for the entire obligation, but a paying party may have a right of contribution and indemnity from nonpaying parties. (Garner, 1999, p. 926)

A diferença entre joint and several liability e joint liability é sutil:

joint liability. Liability shared by two or more parties.

O termo jurídico brasileiro que corresponde melhor a joint liability é "obrigação solidária".

OBRIGAÇÃO SOLIDÁRIA. Direito civil. É aquela resultante de lei ou da vontade das partes, em que, havendo multiplicidade de credores ou de devedores, ou de uns e outros, cada credor terá direito à totalidade da prestação como se fosse o único credor, ou cada devedor estará obrigado pelo débito todo, como se fosse o único devedor. (Diniz, 2005, v. 3, p. 473) 
E o conceito que mais se assemelha a joint and several liability é obrigação solidária passiva:

OBRIGAÇÃO SOLIDÁRIA PASSIVA. Direito civil. Aquela quando, havendo vários devedores, o credor está autorizado a exigir e a receber de um deles a dívida toda; desse modo, fica afastado o princípio concursu partes fiunt, pois cada co-devedor pode ser compelido a pagar todo o débito, apesar de ser, em tese, devedor apenas de sua quota-parte. (Diniz, 2005, v. 3, p. 473)

Esta definição é esclarecida pelo art. 283 do Novo Código Civil (Fiuza, 2006):

Art. 283. O devedor que satisfez a dívida por inteiro tem direito a exigir de cada um dos co-devedores a sua quota, dividindo-se igualmente por todos a do insolvente, se o houver, presumindo-se iguais, no débito, as partes de todos os codevedores.

Esta diferença entre a obrigação solidária passiva e a obrigação solidária não é destacada em contratos, mas existe na legislação.

Nos exemplos abaixo, observe que o termo jointly and severally foi utilizado de maneira consistente nos documentos escritos nos EUA e com inglês correto. O termo singly or jointly do documento dc4 não é comum dentro do universo jurídico, mas existe fora dele. Os outros termos (em p9) são provavelmente o produto de uma tradução para o inglês de um original anterior em português (situação D).

\begin{tabular}{|c|c|c|}
\hline Arquivo & Original & Tradução \\
\hline co3_us-brG & jointly and severally & em conjunto e separadamente ${ }^{L}$ \\
\hline co6_us-brA & jointly and severally liable & $\begin{array}{l}\text { juntamente, e individualmente }^{\mathrm{L}} \text {, } \\
\text { responsável }\end{array}$ \\
\hline co2_us-brG & jointly and severally liable & $\begin{array}{l}\text { individual e solidariamente }^{\mathrm{L}} \\
\text { responsáveis }\end{array}$ \\
\hline
\end{tabular}




\begin{tabular}{|l|l|l|}
\hline pr9_usn-brB & jointly and singularly & em conjunto ou separadamente $^{\mathrm{L}}$ \\
\hline pr9_usn-brB & individually and collectively & individual e coletivamente $^{\mathrm{L}}$ \\
\hline dc4_uk-brE & singly or jointly & isolada ou conjuntamente $^{\mathrm{L}}$ \\
\hline
\end{tabular}

Apesar de existir um termo no universo jurídico brasileiro para o conceito de joint and several liability, nenhuma das traduções nos exemplos acima utilizou este termo. Todas foram literais, e uma solução utilizou solidariamente como um elemento do binômio.

\begin{tabular}{|c|c|c|}
\hline Arquivo & Original & Tradução \\
\hline $\begin{array}{l}\text { dc52_br-usD } \\
\text { (2), dc54_br- } \\
\text { usnE }\end{array}$ & solidariamente & joint and severally ${ }^{\mathrm{EO}}$ \\
\hline pr51_br-usL & em conjunto ou separadamente & jointly and severally $^{\mathrm{M}}$ \\
\hline $\begin{array}{l}\text { co53_br- } \\
\text { usnF }\end{array}$ & $\begin{array}{l}\text { como co-responsáveis, solidariamente, } \\
\text { pelas obrigações ora garantidas. }\end{array}$ & $\begin{array}{l}\text { as joint }{ }^{\mathrm{EO}} \text { co-guarantors of the } \\
\text { obligations guaranteed herein }\end{array}$ \\
\hline $\begin{array}{l}\text { dc53_br- } \\
\text { usnE }\end{array}$ & mas todos respondem solidariamente & $\begin{array}{l}\text { although they assume joint } \\
\text { liability }\end{array}$ \\
\hline co50_br-usL & $\begin{array}{l}\text { tornando-se o XXX S.A., solidário } \\
\text { pagador das exigências contidas nesse } \\
\text { instrumento. }\end{array}$ & $\begin{array}{l}\text { making XXX S.A. the sole }{ }^{\mathrm{ER}} \text { payer } \\
\text { of the requirements stated herein. }\end{array}$ \\
\hline co59_us-brL & separada ou conjuntamente & separately or jointly ${ }^{\mathrm{L}}$ \\
\hline
\end{tabular}

No sentido tradutório contrário, os documentos não especificam se a solidariedade é passiva ou não. Três traduções empregaram o binômio consagrado, uma equivalência operacional para o termo solidariamente. Houve dois casos de equivalência operacional sem o uso do binômio (supondo que não era passiva). A tradução "sole" foi um erro. 


\subsubsection{Organized and existing}

Este binômio é muito comum quando uma sociedade norte-americana é qualificada. Os dois termos não são sinônimos, pois é possível uma sociedade ser constituída e estar fechada, mas é um caso mais raro.

\begin{tabular}{|c|c|c|}
\hline Arquivo & Original & Tradução \\
\hline co3_us-brG & $\begin{array}{l}\text { a corporation duly organized and } \\
\text { validly existing }\end{array}$ & $\begin{array}{l}\text { sociedade devidamente constituída } \mathrm{e} \\
\text { com existência }^{\mathrm{L}} \text { válida }\end{array}$ \\
\hline pr4_ukn-brM & company duly organized and existing & $\begin{array}{l}\text { sociedade devidamente constituída e } \\
\text { existente }^{\mathrm{L}}\end{array}$ \\
\hline pr3_us-brB & a corporation organized and existing & sociedade constituída e existente $^{\mathrm{L}}$ \\
\hline co5_us-brJ & a company established and existing & empresa constituída e existente $^{\mathrm{L}}$ \\
\hline col1_us-brN & a corporation organized under the laws & $\begin{array}{l}\text { uma sociedade constituída } \\
\text { a legislação }\end{array}$ \\
\hline pr8_ukn-brH & company duly organized and existing & $\begin{array}{l}\text { sociedade devidamente } \underline{\text { constituída }}^{\mathrm{L}} \\
\text { e vigente }^{\mathrm{M}}\end{array}$ \\
\hline co7_usn-brF & $\begin{array}{l}\text { any domestic or foreign company } \\
\text { established at the date of signature }\end{array}$ & $\begin{array}{llll}\text { qualquer empresa nacional ou } & \text { ou } \\
\text { estrangeira }^{\text {existente }^{\mathrm{L}}} \text { à data } \\
\text { assinatura }\end{array}$ \\
\hline
\end{tabular}

Nos exemplos acima, todos menos um são traduções literais.

\begin{tabular}{|c|c|c|}
\hline Arquivo & Original & Tradução \\
\hline dc1_us-brE & $\begin{array}{l}\text { The purpose or purposes for which the } \\
\text { Corporation is organized }\end{array}$ & $\begin{array}{l}\text { O objetivo ou objetivos para os } \\
\text { quais a Sociedade é organizada }^{\mathrm{ER}}\end{array}$ \\
\hline co2_us-brG & $\begin{array}{l}\text { the Undersigned is incorporated or } \\
\text { otherwise organized }\end{array}$ & 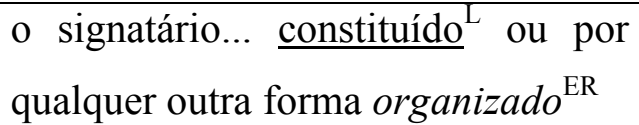 \\
\hline
\end{tabular}

Nestes dois exemplos, o tradutor empregou um falso cognato, pois sociedades são constituídas e não organizadas na terminologia jurídica brasileira. 


\begin{tabular}{|c|c|c|}
\hline Arquivo & Original & Tradução \\
\hline $\begin{array}{l}\text { dc54_br- } \\
\text { usnE (2) }\end{array}$ & $\begin{array}{l}\text { sociedade por quotas de } \\
\text { responsabilidade limitada, existente e } \\
\text { constituída }\end{array}$ & $\begin{array}{l}\text { a limited liability company, existing } \\
\text { and organized }^{\mathrm{L}}\end{array}$ \\
\hline $\begin{array}{l}\text { dc53_br- } \\
\text { usnE }\end{array}$ & constituída & organized $^{\mathrm{L}}$ \\
\hline dc51_br-usL & sociedade devidamente constituída & a corporation duly incorporated $^{L}$ \\
\hline
\end{tabular}

Há poucas ocorrências no sentido tradutório contrário—-todas traduções literais.

\subsubsection{Representations and warranties}

Há uma diferença sutil entre representation e warranty. Segundo o Black's Law Dictionary:

representation. $n$. A presentation of fact - either by words or by conduct - made to induce someone to act, esp. to enter into a contract. (Garner, 1999, p. 1303)

warranty. $n$. An express or implied promise that something in furtherance of the contract is guaranteed by one of the contracting parties; esp., a seller's promise that the thing being sold is as represented or promised. A warranty differs from a representation in four principal ways: (1) a warranty is an essential part of a contract, while a representation is usually only a collateral inducement, (2) a warranty is always written on the face of the contract, while a representation may be written or oral, (3) a warranty is conclusively presumed to be material, while the burden is on the party claiming breach to show that a representation is material, and (4) a warranty must be strictly complied with, while substantial truth is the only requirement for a representation. (Garner, 1999, p. 1581) 


\begin{tabular}{|c|c|c|}
\hline Arquivo & Original & Tradução \\
\hline col1_us-brN & $\begin{array}{l}\text { REPRESENTATIONS AND } \\
\text { WARRANTIES }\end{array}$ & $\begin{array}{l}\text { DECLARAÇÕES E } \\
\text { GARANTIAS }^{\mathrm{L}}\end{array}$ \\
\hline co3_us-brG & representation or warranty & declaração ou garantia $^{\mathrm{L}}$ \\
\hline co7_usn-brF & representations and warranties & representações $^{\mathrm{ER}}$ e garantias ${ }^{\mathrm{L}}$ \\
\hline co7_usn-brF & $\begin{array}{l}\text { make any express or implied } \\
\text { representation or warranty }\end{array}$ & $\begin{array}{l}\text { faz qualquer representação } \\
\text { nem apresenta qualquer } \\
\text { garantia }^{\mathrm{L}} \text {, expressa ou } \\
\text { implícita }\end{array}$ \\
\hline co6_us-brA & contracts, warranties or representations & $\begin{array}{l}\text { contrato, garantias } \\
\text { representações }^{\mathrm{L}}\end{array}$ \\
\hline co2_us-brG & representation, warranty or covenant & $\begin{array}{l}\text { declaração, garantia }^{\mathrm{L}} \text { ou } \\
\text { acordo }\end{array}$ \\
\hline co2_us-brG & $\begin{array}{l}\text { representation or warranty made or } \\
\text { entered into }\end{array}$ & $\begin{array}{l}\text { declaração }^{\mathrm{L}} \text { efetuada ou } \\
\text { garantia }^{\mathrm{L}} \text { assumida }\end{array}$ \\
\hline
\end{tabular}

Nos exemplos acima, 5 traduções são literais, com representation traduzido como declaração. Em outros dois exemplos, representation vem traduzido como representação, um falso cognato para este sentido de representation.

Além de declaração, outra possível tradução por representation seria:

APRESENTAÇÃO. 1. Na linguagem jurídica em geral, significa, em regra: a) ato pelo qual se levam à presença de alguém um documento ou fato, para sua ciência, ou para que haja consecução de algum objetivo pretendido; [...] 4. Direito comercial. a) Aspecto de uma mercadoria oferecida à venda, com o escopo de atrair o consumidor; [...] 7. Direito do consumidor. Ato pelo qual o fornecedor de serviço presta informações fundamentais aos consumidores sobre o produto ou serviço oferecido (Fernando Gherardini Santos). (Diniz, 2005, v. 1, p. 283) 
O binômio também ocorre no corpus ing-orig nos arquivos c123, c120, c102, co11, co124 e co118. No sentido tradutório contrário, o termo garantia não ocorre como parte de um binômio.

Este binômio também ocorre como uma combinação de dois verbos: represent and warrant.

\begin{tabular}{|l|l|l|}
\hline Arquivo & Original & Tradução \\
\hline $\begin{array}{l}\text { co11_us-brN (2), } \\
\text { co3_us-brG, } \\
\text { co2_us-brG }\end{array}$ & represents and warrants & declara e garante $^{\mathrm{L}}$ \\
\hline co6_us-brA & represents and warrants & \\
\hline co5_us-brJ & declare and warrant, & representa $^{\mathrm{ER}}$ e garante $^{\mathrm{L}}$ \\
\hline
\end{tabular}

Aqui temos o mesmo padrão visto para o binômio de substantivos - tradução literal com uma ocorrência de erro devido ao falso cognato.

\subsubsection{Resumo das freqüências de ocorrência e conclusões}

Em resumo, a figura 6.3 mostra a freqüência de ocorrência de soluções representando cada grau de ocorrência (veja o apêndice para os dados brutos completos) para os exemplos da seção 6.3. 


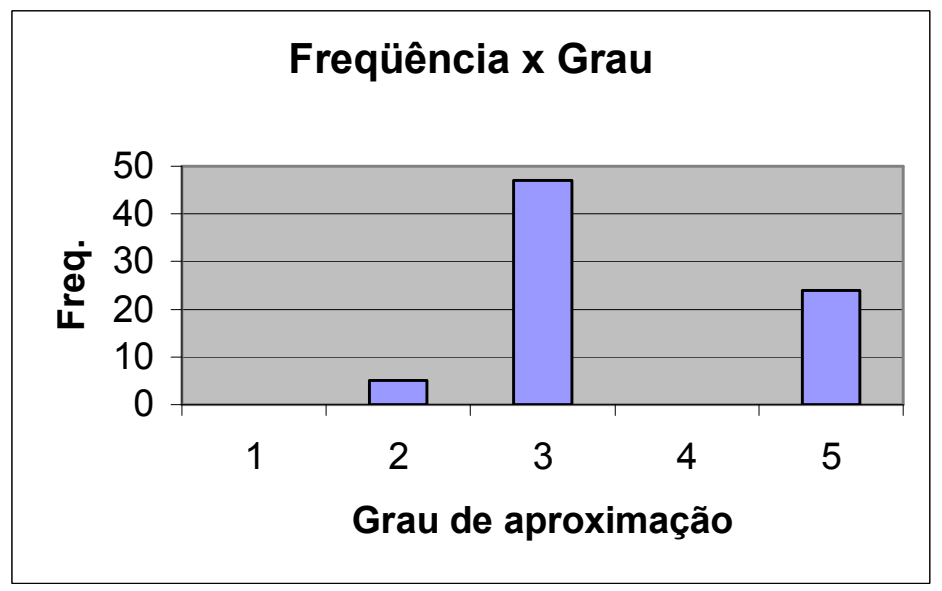

Figura 6.3 - Freqüência de ocorrência de cada grau de aproximação — binômios não tautológicos

Como esperado para binômios não tautológicos, a maioria das traduções é literal e se encaixa no grau 3 de aproximação. Quando os dois elementos do binômio representam conceitos contrários (como jointly and severally) a tradução literal foi ainda mais comum.

\begin{tabular}{|l|c|c|c|c|c|}
\hline Modalidade & Grau 1 & Grau 2 & Grau 3 & Grau 4 & Grau 5 \\
\hline EDV & - & - & 1 & - & 6 \\
\hline EO & - & - & - & - & 4 \\
\hline ER & - & 2 & 1 & - & - \\
\hline L & - & - & 45 & - & 12 \\
\hline M & - & - & - & - & 2 \\
\hline outro & - & 3 ER-L & - & - & - \\
\hline totais & $\mathbf{0}$ & $\mathbf{5}$ & $\mathbf{4 7}$ & $\mathbf{0}$ & $\mathbf{2 4}$ \\
\hline
\end{tabular}

Tabela 6.5 - Freqüência de ocorrência de modalidade por grau de aproximação — binômios não tautológicos

Os três casos de ER-L (tradução literal resultando em erro) foram todos devido ao falso cognato represent/representar no contexto do binômio represent and warrant. Muitas das 
traduções literais (12 ocorrências) se encaixam no grau 5 por soarem naturais também na língua de chegada. 


\section{Conclusões}

Freqüências de ocorrência foram apresentadas no final de cada seção do capítulo 5 e do capítulo 6. Neste capítulo, apresento um resumo desses dados, freqüências calculadas baseadas em outros parâmetros, bem como as conclusões que esses dados sugerem.

\subsection{Marcadores referenciais e estilísticos}

A tabela 7.1 mostra um resumo dos graus de aproximação empregados para os dois tipos de marcadores e para todos os exemplos dos corpora paralelos.

\begin{tabular}{|c|c|c|c|}
\hline $\begin{array}{c}\text { Grau de } \\
\text { Aproximação }\end{array}$ & $\begin{array}{c}\text { Marcadores } \\
\text { Referenciais }\end{array}$ & $\begin{array}{c}\text { Marcadores } \\
\text { Estilísticos }\end{array}$ & Total \\
\hline 1 & 18 & 0 & 18 \\
\hline 2 & 16 & 20 & 36 \\
\hline 3 & 110 & 74 & 184 \\
\hline 4 & 63 & 0 & 63 \\
\hline 5 & 82 & 90 & 172 \\
\hline totais & 289 & 184 & 473 \\
\hline
\end{tabular}

Tabela 7.1 - Resumo de freqüencia de ocorrência por grau por tipo de marcador

Os mesmos dados são representados novamente na figura 7.1 abaixo. 


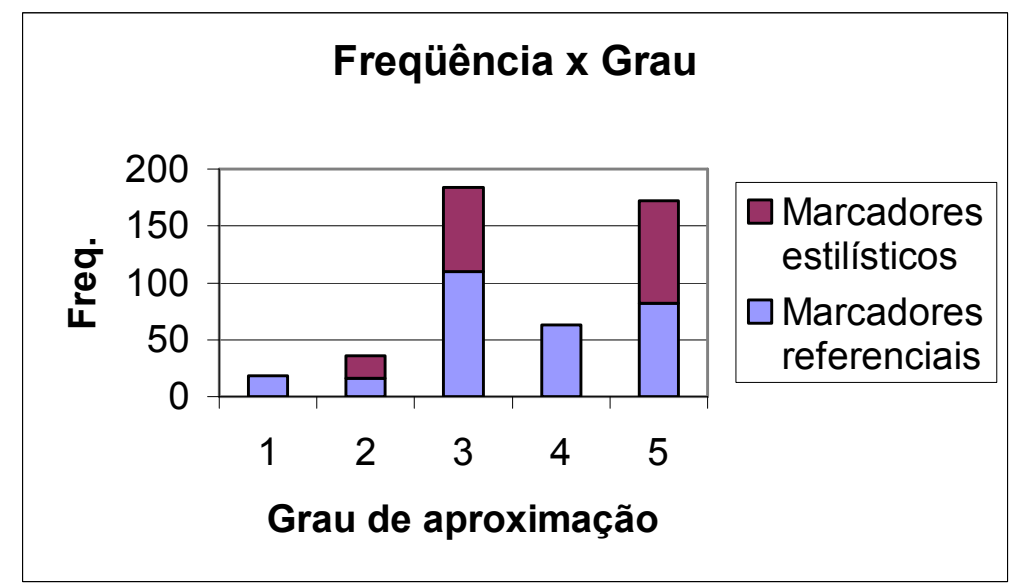

Figura 7.1 - Resumo de freqüência de ocorrência por grau por tipo de marcador

Observe que não houve nenhuma solução tradutória dos graus 1 e 4 para os marcadores estilísticos. Os mesmos dados são apresentados em forma de percentagens na tabela 7.2.

\begin{tabular}{|c|c|c|c|}
\hline $\begin{array}{c}\text { Grau de } \\
\text { Aproximação }\end{array}$ & $\begin{array}{c}\text { Marcadores } \\
\text { Referenciais }\end{array}$ & $\begin{array}{c}\text { Marcadores } \\
\text { Estilísticos }\end{array}$ & Total \\
\hline 1 & $6,2 \%$ & $0 \%$ & $3,8 \%$ \\
\hline 2 & $5,5 \%$ & $10,9 \%$ & $7,6 \%$ \\
\hline 3 & $38,1 \%$ & $40,2 \%$ & $38,9 \%$ \\
\hline 4 & $21,8 \%$ & $0 \%$ & $13.3 \%$ \\
\hline 5 & $28,4 \%$ & $48,9 \%$ & $36,4 \%$ \\
\hline totais & $100 \%$ & $100 \%$ & $100 \%$ \\
\hline
\end{tabular}

Tabela 7.2 - Resumo de freqüencia de ocorrência por grau por tipo de marcador (percentagens)

As percentagens dos graus dentro de cada tipo de marcador mostram que o uso de soluções correspondentes ao grau 3 foi quase igual para os dois tipos de marcadores. Devido à natureza dos dois tipos de marcadores, o número grande de soluções do grau 4 para marcadores referenciais e o número grande de soluções do grau 5 para marcadores estilísticos era 
esperado. Entende-se que enquanto a tradução pode (e até deve, em algumas situações) mostrar sua alteridade em questões referenciais, não o deve tanto nas questões estilísticas.

A tabela 7.3 apresenta um resumo das modalidades e combinações de modalidades empregadas para os dois tipos de marcadores e para todos os exemplos dos corpora paralelos. Estas categorias foram definidas na seção 4.5.5 para facilitar a análise quantitativa, pois o número de combinações de modalidades possível foi alto.

\begin{tabular}{|c|c|c|c|}
\hline Modalidade & $\begin{array}{l}\text { Marcadores } \\
\text { Referenciais }\end{array}$ & $\begin{array}{c}\text { Marcadores } \\
\text { Estilísticos }\end{array}$ & Total \\
\hline Correção & 4 & -- & 4 \\
\hline Decalque & 7 & 5 & 12 \\
\hline Eq. Cultural & 1 & -- & 1 \\
\hline Eq. Discursiva & 3 & 40 & 43 \\
\hline Eq. Funcional & 18 & 1 & 19 \\
\hline Empréstimo (EMP) & 18 & -- & 18 \\
\hline $\mathrm{EMP}+\mathrm{L}$ & 12 & -- & 12 \\
\hline EMP-EX-L & 16 & -- & 16 \\
\hline $\mathrm{EMP}+\mathrm{EX} \pm$ outro & 17 & -- & 17 \\
\hline EMP+outro & 5 & -- & 5 \\
\hline Eq. Operacional & 20 & 7 & 27 \\
\hline Erro & -- & 3 & 3 \\
\hline Erro + Literal & -- & -- & 0 \\
\hline Explicitação (EX) + Literal & 5 & -- & 5 \\
\hline Implicitação & 2 & 4 & 6 \\
\hline Literal (L) & 60 & 93 & 153 \\
\hline Literal + Transcrição & 4 & -- & 4 \\
\hline Modulação (M) & 31 & 21 & 52 \\
\hline ME (especif.) & 1 & -- & 1 \\
\hline
\end{tabular}




\begin{tabular}{|l|c|c|c|}
\hline MG (general.) & 10 & -- & 10 \\
\hline MP (parte) & 16 & -- & 16 \\
\hline MT (todo) & 6 & -- & 6 \\
\hline Omissão & 5 & 2 & 2 \\
\hline Transcrição & 2 & -- & 34 \\
\hline Outro & 26 & 8 & \\
\hline
\end{tabular}

Tabela 7.3 - Resumo de freqüencia de ocorrência por modalidade por tipo de marcador

A tabela 7.3 mostra que um número menor de tipos de modalidades foi empregado para a tradução de marcadores estilísticos, com a ausência especificamente de empréstimo e transcrição. Para marcadores estilísticos, tradução literal, equivalência discursiva e modulação foram claramente as modalidades de preferência. As modalidades empregadas para tradução de marcadores referenciais apresentaram maior dispersão. A tabela 7.4 apresenta os dados da tabela 7.3 na forma de percentagens.

\begin{tabular}{|l|c|c|c|}
\hline Modalidade & $\begin{array}{c}\text { Marcadores } \\
\text { Referenciais (\%) }\end{array}$ & $\begin{array}{c}\text { Marcadores } \\
\text { Estilísticos (\%) }\end{array}$ & Total (\%) \\
\hline Correção & 1,4 & - & 0,9 \\
\hline Decalque & 2,4 & 2,7 & 2,5 \\
\hline Eq. Cultural & 0,4 & - & 0,2 \\
\hline Eq. Discursiva & 1,0 & 21,7 & 9,1 \\
\hline Eq. Funcional & 6,2 & 0,5 & 4,0 \\
\hline Empréstimo (EMP) & 6,2 & - & 3,8 \\
\hline EMP+L & 4,2 & - & 2,5 \\
\hline EMP-EX-L & 5,5 & - & 3,4 \\
\hline EMP+EX \pm outro & 5,9 & - & 1,1 \\
\hline EMP+outro & 1,7 & - & 5,7 \\
\hline Eq. Operacional & 6,9 & 3,8 & \\
\hline
\end{tabular}




\begin{tabular}{|l|c|c|c|}
\hline Erro & - & 1,6 & 0,6 \\
\hline Erro + Literal & - & - & - \\
\hline Explicitação (EX) + Literal & 1,7 & - & 1,1 \\
\hline Implicitação & 0,7 & 2,2 & 1,3 \\
\hline Literal (L) & $\mathbf{2 0 , 8}$ & 50,5 & 32,4 \\
\hline Literal + Transcrição & 1,4 & - & 0,9 \\
\hline Modulação (M) & 10,7 & 11,4 & 11,0 \\
\hline ME (especif.) & 0,4 & - & 0,2 \\
\hline MG (general.) & 3,5 & - & 2,1 \\
\hline MP (parte) & 5,5 & - & 1,3 \\
\hline MT (todo) & 2,1 & - & 1,5 \\
\hline Omissão & 1,7 & 1,1 & 0,4 \\
\hline Transcrição & 0,7 & - & 7,2 \\
\hline Outro & 9,0 & 4,4 & $\mathbf{1 0 0}$ \\
\hline totais & $\mathbf{1 0 0}$ & $\mathbf{1 0 0}$ & \\
\hline
\end{tabular}

Tabela 7.4 - Resumo de freqüencia de ocorrência por modalidade por tipo de marcador (percentagens)

A distribuição das soluções empregadas para os marcadores referenciais é mais fácil interpretar juntando os tipos de modulação (M, ME, MG, MP e MT) e as variedades de uso de empréstimo (EMP + qualquer outra modalidade). Vistas assim, as percentagens são 20,8\% de tradução literal, $22,1 \%$ de modulação, $17,3 \%$ de empréstimo junto com outra modalidade, $6,2 \%$ de empréstimo empregado sozinho e 6,2\% de equivalência funcional. Talvez uma das maiores surpresas dos resultados foi esta baixa percentagem de equivalência funcional. Implicitação e omissão também foram utilizadas menos do que o esperado, principalmente para simplificar a tradução de binômios ou arcaísmos. 


\subsection{Análise de outros parâmetros}

Para cada arquivo, também dispus das seguintes informações: o tradutor, se a tradução era juramentada ou não, se a tradução era para a língua de domínio mais ativo do tradutor ou não, e a situação tradutória (este último foi muitas vezes apenas estimada a partir dos textos).

\subsubsection{Traduções para o inglês e para o português}

$\mathrm{Na}$ tabela 7.5 apresento os dados referentes ao grau de aproximação para marcadores referenciais para os dois corpora representando os dois sentidos tradutórios: inglês para português brasileiro e português brasileiro para inglês.

\begin{tabular}{|c|c|c|c|c|}
\hline \multicolumn{5}{|c|}{ Marcadores Referenciais } \\
\hline Grau & corpus ing-br & corpus br-ing & corpus ing-br & corpus br-ing \\
\hline 1 & 3 & 15 & $3 \%$ & $9 \%$ \\
\hline 2 & 6 & 10 & $5 \%$ & $6 \%$ \\
\hline 3 & 51 & 59 & $\mathbf{4 5 \%}$ & $\mathbf{3 4 \%}$ \\
\hline 4 & 10 & 53 & $\mathbf{9 \%}$ & $\mathbf{3 0 \%}$ \\
\hline 5 & 44 & 38 & $\mathbf{3 9 \%}$ & $\mathbf{2 2 \%}$ \\
\hline total & 114 & 175 & $3 \%$ & $9 \%$ \\
\hline
\end{tabular}

Tabela 7.5 - Ocorrências e \% de exemplos por grau de documentos traduzidos para português (corpus ing-br) e para inglês (corpus br-ing) - marcadores referenciais

Observe que o número de exemplos extraído do corpus br-ing é consideravelmente maior do que o número extraído do corpus ing-br. Isso se deve à seção 5.5 (Qualificações), em que somente traduções de português para inglês foram analisadas. Lembre que as soluções tradutórias daquela seção (resumidas na seção 5.5.5) encaixaram-se principalmente nos graus 1 e 4 . A seção 5.5 incluiu somente traduções de português para inglês por um motivo simples - documentos jurídicos norte-americanos e britânicos não contêm os mesmos dados na qualificação das partes. Pessoas físicas e jurídicas são qualificadas por seus nomes e endereços, dados omitidos dos documentos dos corpora por motivos de confidencialidade 
(mas normalmente apenas transcritos e portanto sem interesse para os fins deste estudo). Muitos dos documentos no corpus ing-br contiveram qualificações no estilo brasileiro devido a uma ou mais partes serem brasileiras; porém, essas qualificações já eram traduções para o inglês do português (e por tradutores desconhecidos), e sua tradução de volta para o português não seria representativa do tipo de tradução que este estudo buscava analisar.

A figura 7.2 exibe os dados para marcadores referenciais nos dois sentidos tradutórios e um cálculo a mais que representa os dados do corpus br-ing sem os dados sobre as traduções das qualificações (seção 5.5).

\section{Marcadores Referenciais - \% por sentido, com ajuste}

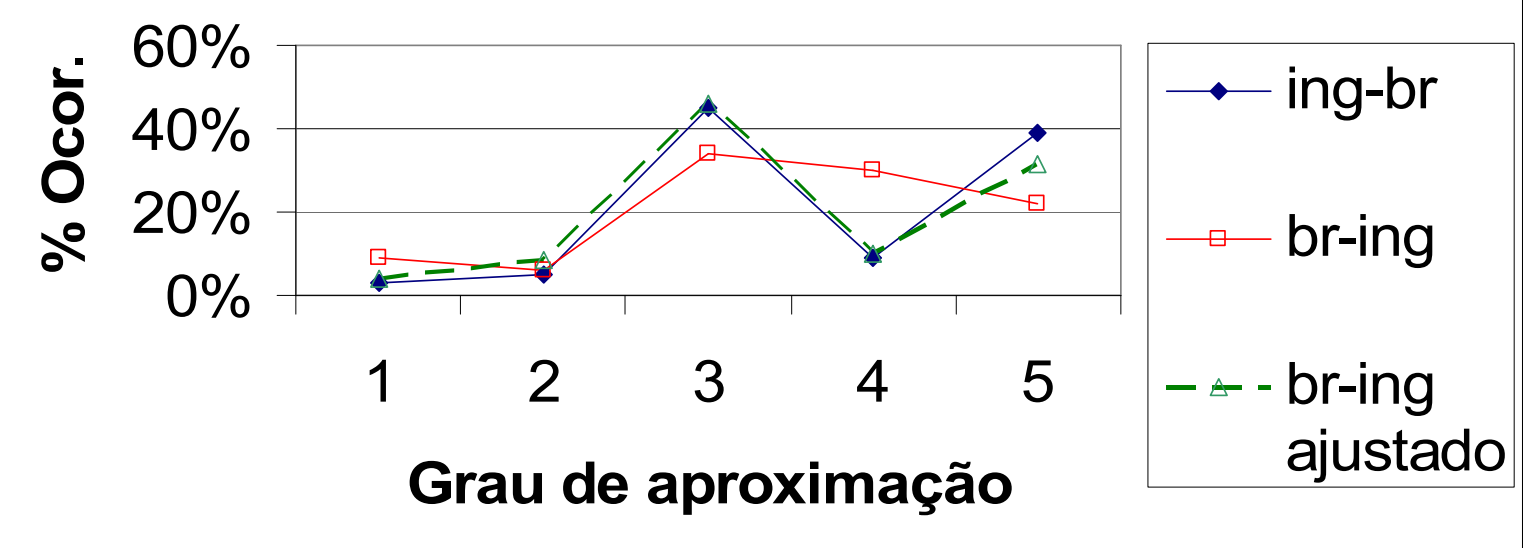

Figura 7.2 - \% de Ocorrência por grau para os dois sentidos tradutórios, com ajuste marcadores referenciais

Como se vê, sem a influência das soluções tradutórias para as qualificações, os dois sentidos tradutórios têm quase exatamente o mesmo perfil (em termos de grau de aproximação). Portanto, os dados da seção 5.5 explicam as diferenças entre as percentagens apresentadas na tabela 7.5 . 
Na tabela 7.6 apresento os dados referentes ao grau de aproximação para marcadores estilísticos para os dois corpora representando os dois sentidos tradutórios: inglês para português brasileiro e português brasileiro para inglês. $\mathrm{O}$ número de exemplos em cada sentido é muito mais equilibrado do que para marcadores referenciais.

\begin{tabular}{|c|c|c|c|c|}
\hline \multicolumn{5}{|c|}{ Marcadores Estilísticos } \\
\hline Grau & corpus ing-br & corpus br-ing & corpus ing-br & corpus br-ing \\
\hline 1 & 0 & 0 & $0 \%$ & $0 \%$ \\
\hline 2 & 12 & 8 & $12 \%$ & $10 \%$ \\
\hline 3 & 43 & 31 & $42 \%$ & $38 \%$ \\
\hline 4 & 0 & 0 & $0 \%$ & $0 \%$ \\
\hline 5 & 48 & 42 & $47 \%$ & $52 \%$ \\
\hline total & 103 & 81 & $100 \%$ & $100 \%$ \\
\hline
\end{tabular}

Tabela 7.6 - Ocorrências e \% de exemplos por grau de documentos traduzidos para português (corpus ing-br) e para inglês (corpus br-ing) - marcadores estilísticos

As percentagens de ocorrências para cada grau são quase iguais. Portanto, não há comportamento diferente (segundo a medida de grau de aproximação) para marcadores estilísticos, e as diferenças vistas nos dois sentidos tradutórios para marcadores referenciais podem ser entendidos através do estudo da tradução de qualificações.

A tabela 7.7 mostra a percentagem de ocorrências por modalidade, dividindo os documentos por sentido tradutório. Simplifiquei as categorias juntando todas as que têm empréstimo mais pelo menos uma outra modalidade em uma categoria, e juntando todos os tipos de modulação. 


\begin{tabular}{|l|c|c|}
\hline \multicolumn{1}{|c|}{ Modalidade(s) } & $\begin{array}{c}\text { Corpus } \\
\text { br-ing }\end{array}$ & $\begin{array}{c}\text { Corpus } \\
\text { ing-br }\end{array}$ \\
\hline Correção & $0,0 \%$ & $1,8 \%$ \\
\hline Decalque & $1,6 \%$ & $3,7 \%$ \\
\hline Eq. Cultural & $0,4 \%$ & $0,0 \%$ \\
\hline Eq. Discursiva & $10,9 \%$ & $6,9 \%$ \\
\hline Eq. Funcional & $3,1 \%$ & $5,1 \%$ \\
\hline Empréstimo (EMP) & $5,9 \%$ & $1,4 \%$ \\
\hline Empréstimo + qualquer outra & $18 \%$ & $1,8 \%$ \\
\hline Eq. Operacional & $8 \%$ & $3 \%$ \\
\hline Erro & $0,4 \%$ & $0,9 \%$ \\
\hline Erro + Literal & $0,0 \%$ & $0,0 \%$ \\
\hline Explicitação (EX) + Literal & $1,6 \%$ & $0,5 \%$ \\
\hline Implicitação & $0,4 \%$ & $2,3 \%$ \\
\hline Literal (L) & $19,9 \%$ & $47,0 \%$ \\
\hline Literal + Transcrição & $1,2 \%$ & $0,5 \%$ \\
\hline Modulação (qualquer tipo) & $19,5 \%$ & $16,1 \%$ \\
\hline Omissão & $2,0 \%$ & $0,9 \%$ \\
\hline Transcrição & $0,0 \%$ & $0,9 \%$ \\
\hline Outro & $7,0 \%$ & $7,4 \%$ \\
\hline totais & $100 \%$ & $100 \%$ \\
\hline
\end{tabular}

Tabela 7.7 - Percentagens de exemplos por modalidade traduzidos para português (corpus ing-br) e para inglês (corpus br-ing) - resumidas

A diferença entre as percentagens para empréstimo (com e sem outras modalidades) também deve ser devida aos resultados da seção 5.5 , em que só traduções de português para inglês foram analisadas pelos motivos explicados acima. Apenas 9 soluções tradutórias da seção 5.5 
não empregaram empréstimo, portanto os números de ocorrência das outras modalidades (e as percentagens relativas entre as outras modalidades) não foram afetados pela presença dos dados da seção 5.5. É importante lembrar que os dados da seção 5.5 representam soluções tradutórias importantes presentes principalmente no sentido tradutório do corpus br-ing.

As outras diferenças principais foram:

1. apenas $19,9 \%$ das traduções para inglês foram traduções literais, mas este número subiu para $47 \%$ para traduções para português; esta tendência foi vista principalmente na tradução de binômios no capítulo 6;

2. juntando os três tipos de equivalências, havia $22 \%$ de emprego de equivalências nas traduções para inglês e somente $15 \%$ nas traduções para português. Esta diferença pode ser devida à hegemonia dos EUA e do inglês. Como em geral brasileiros são mais bem informados sobre os EUA do que norte-americanos sobre o Brasil, os tradutores podem considerar importante utilizar termos familiares ao leitor norteamericano da tradução.

Observe, porém, que as percentagens de soluções que empregaram modulação foram semelhantes. Para todas as outras modalidades, as percentagens foram baixas demais para ser possível tirar conclusões.

\subsubsection{Traduções juramentadas e não juramentadas}

A tabela 7.8 resume as ocorrências de soluções de cada grau de aproximação extraídas de traduções juramentadas e não juramentadas do corpus ing-br. 


\begin{tabular}{|c|c|c|c|c|}
\hline \multirow{2}{*}{ ing-br } & \multicolumn{2}{|c|}{$\begin{array}{c}\text { Ocorrências } \\
\text { no corpus ing-br }\end{array}$} & $\begin{array}{c}\text { Não } \\
\text { Juramentado }\end{array}$ & Juramentado grau por categoria \\
\hline Grau & Juramentado & 1 & $2 \%$ & Não \\
Juramentado & $1 \%$ \\
\hline 1 & 2 & 8 & $9 \%$ & $8 \%$ \\
\hline 2 & 10 & 42 & $\mathbf{4 7 \%}$ & $\mathbf{4 0 \%}$ \\
\hline 3 & 52 & 8 & $\mathbf{2 \%}$ & $\mathbf{8 \%}$ \\
\hline 4 & 2 & 47 & $41 \%$ & $44 \%$ \\
\hline 5 & 45 & 106 & $100 \%$ & $100 \%$ \\
\hline totais & 111 & & & \\
\hline
\end{tabular}

Tabela 7.8 - Ocorrências e \% de exemplos por grau de documentos juramentados e nãocorpus ing-br

Dos 217 exemplos do corpus ing-br, 111 são de traduções juramentadas e 106 são de traduções não juramentadas. A maior diferença entre traduções juramentadas e não foi uma percentagem maior de soluções de grau 4 nas traduções não juramentadas e uma respectiva percentagem menor de soluções de grau 3. Isso provavelmente foi devido à natureza literalizante da tradução juramentada já estudada por Aubert (2005b). A percentagem de ocorrências para os outros graus foi quase igual para traduções juramentadas e não.

A tabela 7.9 resume as ocorrências de soluções de cada grau de aproximação extraídas de traduções juramentadas e não juramentadas do corpus br-ing 


\begin{tabular}{|c|c|c|c|c|}
\hline \multirow{2}{*}{ br-ing } & \multicolumn{2}{|c|}{$\begin{array}{c}\text { Ocorrências } \\
\text { no corpus br-ing }\end{array}$} & $\begin{array}{c}\text { Não } \\
\text { Juramentado }\end{array}$ & Juramentado grau por categoria \\
\hline Grau & Juramentado & 9 & $\begin{array}{c}\text { Não } \\
\text { Juramentado }\end{array}$ \\
\hline 1 & 6 & 9 & $8 \%$ & $5 \%$ \\
\hline 2 & 6 & 64 & $36 \%$ & $75 \%$ \\
\hline 3 & 26 & 40 & $\mathbf{1 8 \%}$ & $\mathbf{2 2 \%}$ \\
\hline 4 & 13 & 58 & $30 \%$ & $32 \%$ \\
\hline 5 & 22 & 183 & $100 \%$ & $100 \%$ \\
\hline totais & 73 & & & \\
\hline
\end{tabular}

Tabela 7.9 - Ocorrências e \% de exemplos por grau de documentos juramentados e nãocorpus br-ing

Dos 256 exemplos do corpus br-ing, 73 são de traduções juramentadas e 183 são de traduções não juramentadas. A maior diferença entre traduções juramentadas ou não no corpus br-ing foi a percentagem levemente maior de traduções do grau 4. Os dados para este e para os outros graus eram basicamente iguais.

\subsubsection{Traduções para a língua de domínio mais ativo e não}

Apenas dois documentos curtos foram traduzidos de inglês para português por não brasileiros. Por esse motivo, os dados para o corpus ing-br para esta variável (LDA) não seriam representativos de nenhuma tendência e só os dados para o corpus br-ing são apresentados na tabela 7.10 abaixo. 


\begin{tabular}{|c|c|c|c|c|}
\hline \multirow{2}{*}{ br-ing } & \multicolumn{2}{|c|}{$\begin{array}{c}\text { Ocorrências } \\
\text { no corpus br-ing }\end{array}$} & \\
\hline Grau & Para a LDA & Não para a LDA & Para a LDA & Não para a LDA \\
\hline 1 & 7 & 8 & $5 \%$ & $7 \%$ \\
\hline 2 & 10 & 8 & $7 \%$ & $7 \%$ \\
\hline 3 & 50 & 40 & $34 \%$ & $37 \%$ \\
\hline 4 & 31 & 22 & $21 \%$ & $20 \%$ \\
\hline 5 & 49 & 31 & $\mathbf{3 3 \%}$ & $\mathbf{2 8 \%}$ \\
\hline total & 147 & 109 & $100 \%$ & $100 \%$ \\
\hline
\end{tabular}

Tabela 7.10 - Ocorrências e\% de exemplos por grau de documentos traduzidos para a LDA do tradutor e não - corpus br-ing

Em termos de grau de aproximação, quase não há diferença (em termos de percentagem) entre as soluções tradutórias dos tradutores traduzindo para sua língua de domínio mais ativo e não. A maior diferença foi para o grau 5, localização, em que os tradutores com inglês como sua LDA exibiram uma tendência levemente maior a localização.

\subsubsection{Situações tradutórias}

O conceito de situações tradutórias foi apresentado no capítulo 3, seção 3.4.1. Em resumo, as situações definidas neste estudo são:

A1 O documento original é assinado e é válido. A tradução ajuda a compreensão da $2^{\mathrm{a}}$ parte e de terceiros. O autor contrata o tradutor.

A2 O documento original é um modelo, mas a tradução é assinada e se torna a única versão válida. $\mathrm{O}$ autor contrata o tradutor. 
B1 O documento original é assinado e é válido. A tradução ajuda a compreensão da $2^{\mathrm{a}}$ parte e de terceiros. Alguém que não o autor contrata o tradutor.

B2 O documento original é um modelo, mas a tradução é assinada e se torna a única versão válida. Alguém que não o autor contrata o tradutor. (Nenhum documento dos corpora paralelo foi desse tipo).

C1 O documento original é assinado e é válido. A tradução é juramentada e o receptor é o governo.

C2 O documento original é assinado e é válido. A tradução é normal ou certificada por um tradutor não público, e o receptor é o governo.

D1 O autor do documento original encomenda uma versão para o idioma da segunda parte (ao contrato ou procuração). Esta tradução é assinada.

D2 O autor do documento original da situação D1 encomenda uma tradução juramentada de volta para a língua do autor, e o documento se torna válida no idioma original.

D3 O autor do documento original da situação D1 encomenda uma tradução não juramentada (mas talvez certificada) de volta para a língua do autor. Se esta tradução se torna válida ou não depende das leis do país em questão.

Em muitos casos, não foi possível saber com certeza em qual situação tradutória o documento se encaixava. Observe que quando uma agência envia uma tradução a um tradutor, é freqüente o tradutor não saber nem na hora de fazer a tradução em qual situação tradutória ela se encaixa. Nos casos de incerteza, o documento é tratado como se encaixasse em ambas, e portanto os números de ocorrências não somam ao número total porque alguns documentos são representados mais de uma vez. A tabela 7.11 apresenta as percentagens de cada grau dentro de cada situação tradutória. Observe que a última linha indica o número de exemplos que se encaixaram naquela situação tradutória, como referência. 


\begin{tabular}{|c|c|c|c|c|c|c|c|c|}
\hline Grau & A1 & A2 & B1 & C1 & C2 & D1 & D2 & D3 \\
\hline 1 & $6 \%$ & - & $3 \%$ & $5 \%$ & $4 \%$ & $14 \%$ & $2 \%$ & $4 \%$ \\
\hline 2 & $9 \%$ & $17 \%$ & $8 \%$ & $5 \%$ & - & - & $9 \%$ & $4 \%$ \\
\hline 3 & $33 \%$ & $26 \%$ & $44 \%$ & $49 \%$ & $42 \%$ & $43 \%$ & $33 \%$ & $27 \%$ \\
\hline 4 & $23 \%$ & $0 \%$ & $17 \%$ & $10 \%$ & $25 \%$ & $29 \%$ & $4 \%$ & $6 \%$ \\
\hline 5 & $29 \%$ & $57 \%$ & $28 \%$ & $30 \%$ & $29 \%$ & $14 \%$ & $52 \%$ & $58 \%$ \\
\hline No. total & 140 & 23 & 146 & 116 & 24 & 7 & 54 & 48 \\
\hline
\end{tabular}

Tabela 7.11 - Percentagem de ocorrências por grau por situação tradutória

Os dados para a situação tradutória D1 não são suficientes para chegar a uma conclusão (somente 7 exemplos foram extraídos desse documento, pr52, que poderia ter sido C1, D1 ou D2).

Os dados mostram dois perfis: um seguido pelas situações A1, B1, C1 e C2 e o outro seguido pelas situações A2, D2 e D3. A figura 7.3 mostra os dados para as situações com o primeiro perfil em um gráfico e a figura 7.4 apresenta os dados para as situações com o segundo perfil em um segundo gráfico. 


\section{\% de Ocorrências x Situação x Grau}

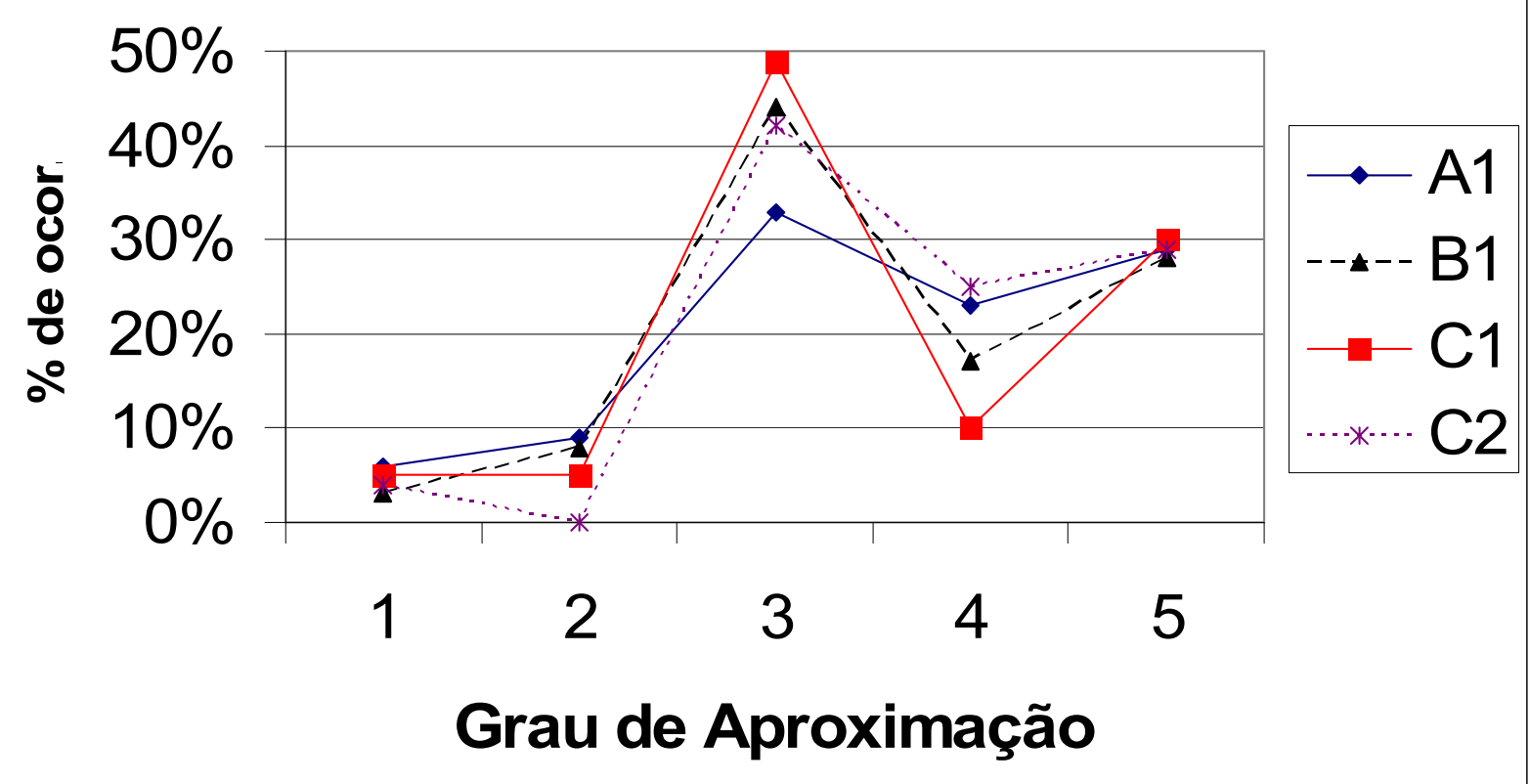

Figura 7.3 - Percentagem de ocorrências por grau para situações A1, B1, C1 e C2

Faz sentido A1 e B1 terem o mesmo perfil, pois a única diferença é quem contratou o tradutor (e em muitos casos não foi possível saber, de modo que há uma sobreposição de dados). C1 e C2 são semelhantes, ambos traduzidos para o receptor governamental (uma agência do governo ou tribunal). A situação $\mathrm{C} 1$, que representa tradução jurídica de um original, tem a maior percentagem de soluções de grau 3 e correspondente menor percentagem de soluções de grau 4. A situação $\mathrm{C} 2$ tem um número muito maior de soluções de grau 4. Isso pode ser devido ao fato de que traduções do tipo $\mathrm{C} 1$ vêm acompanhadas pelo documento original, e portanto o contexto (e alteridade) são aparentes. Uma tradução do tipo C2 não necessariamente seria acompanhada pelo original. 


\section{\% de Ocorrências x Situação x Grau}

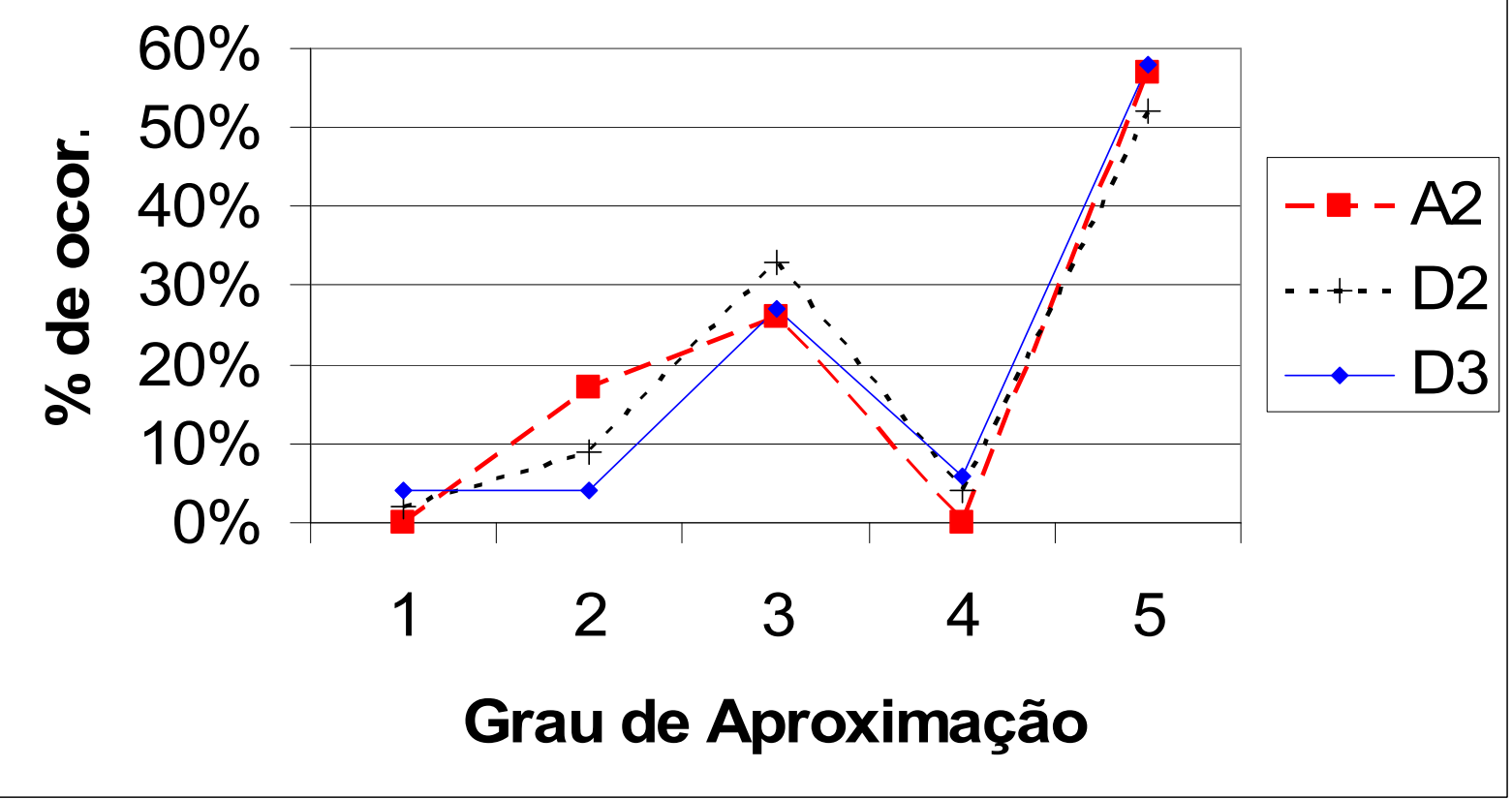

Figura 7.4 - Percentagem de ocorrências por grau para situações A2, D1 e D2

No perfil visto na figura 7.4, os papéis dos graus 3 e 5 são invertidos. Na figura 7.3, o grau 5 representava cerca de $30 \%$ das soluções tradutórias para cada situação, e o grau 3 representava entre $33 \%$ e $49 \%$. Na figura 7.3, no entanto, o grau 5 é responsável por mais de $50 \%$ das soluções tradutórias para as situações A2, D2 e D3, enquanto o grau 3 é responsável por cerca de $30 \%$. A afinidade entre as situações D2 e D3 é claro, pois representam o mesmo passo, com traduções juramentadas na situação D2 e não juramentadas na situação D3. São traduções de uma tradução. A2, ao contrário, representa um modelo em um idioma traduzido para ser utilizado em outro idioma. Talvez a única coisa que tenham em comum seja que a tradução será utilizada no língua de chegada como se fosse original, e precisa seguir mais as normas da língua/país de chegada. Este objetivo é facilitado para as situações D2 e D3, pois 
como tradução de tradução a estrutura do original "original" freqüentemente fica evidente apesar da tradução intermediária.

\subsubsection{Tradutor}

Como os exemplos foram extraídos baseados nos termos relacionados às áreas sob estudo (conceitos financeiros, qualificações, arcaísmos, etc.) e não houve nenhuma tentativa de ter uma boa representação de todos os tradutores, os dados para muitos dos tradutores são poucos demais para analisar. O número total de exemplos extraídos de textos de cada tradutor é fornecido na penúltima linha das tabelas 7.12 e 7.13 para referência. O número de documentos dos quais os exemplos foram extraídos é fornecido na última linha. São, na média, 8-10 exemplos por documento. A primeira linha indica, através das anotações LDA ou "não", se as traduções daquele tradutor foram para a LDA do tradutor ou não para o corpus paralelo em questão.

\begin{tabular}{|c|c|c|c|c|c|c|c|c|c|c|c|}
\hline Grau & $\begin{array}{c}\mathrm{A} \\
\text { (LDA) }\end{array}$ & $\begin{array}{c}\text { B } \\
\text { (LDA) }\end{array}$ & $\begin{array}{c}\text { C } \\
\text { (não) }\end{array}$ & $\begin{array}{c}E \\
(\mathbf{L D A})\end{array}$ & $\begin{array}{c}\text { F } \\
(\text { LDA })\end{array}$ & $\begin{array}{c}\text { G } \\
(\text { LDA })\end{array}$ & $\begin{array}{c}\text { H } \\
\text { (LDA) }\end{array}$ & $\begin{array}{c}\mathbf{J} \\
(\mathbf{L D A})\end{array}$ & $\begin{array}{c}\mathbf{L} \\
\text { (não) }\end{array}$ & $\begin{array}{c}\text { M } \\
(\text { LDA })\end{array}$ & $\begin{array}{c}\mathbf{N} \\
(\mathbf{L D A})\end{array}$ \\
\hline 1 & - & - & - & $4 \%$ & - & - & - & - & $6 \%$ & - & - \\
\hline 2 & $20 \%$ & - & - & $12 \%$ & $20 \%$ & $3 \%$ & - & $8 \%$ & - & $14 \%$ & $10 \%$ \\
\hline 3 & $50 \%$ & $58 \%$ & $50 \%$ & $51 \%$ & $20 \%$ & $52 \%$ & $43 \%$ & $33 \%$ & $29 \%$ & $28 \%$ & $40 \%$ \\
\hline 4 & - & $3 \%$ & $50 \%$ & - & - & $3 \%$ & - & - & $29 \%$ & $3 \%$ & $10 \%$ \\
\hline 5 & $30 \%$ & $39 \%$ & - & $33 \%$ & $60 \%$ & $42 \%$ & $57 \%$ & $58 \%$ & $35 \%$ & $55 \%$ & $40 \%$ \\
\hline $\begin{array}{l}\text { No. } \\
\text { total } \\
\text { ex. }\end{array}$ & 10 & 31 & 2 & 51 & 15 & 33 & 7 & 12 & 17 & 29 & 10 \\
\hline $\begin{array}{l}\text { No. } \\
\text { docs }\end{array}$ & 1 & 3 & 1 & 5 & 2 & 2 & 1 & 2 & 1 & 3 & 1 \\
\hline
\end{tabular}

Tabela 7.12 - Percentagem de ocorrência por grau por tradutor - corpus ing-br 
Para o corpus ing-br, analisarei somente os dados dos tradutores B, E, G e M, pois há pelo menos 30 exemplos ou pelo menos 3 documentos de cada.

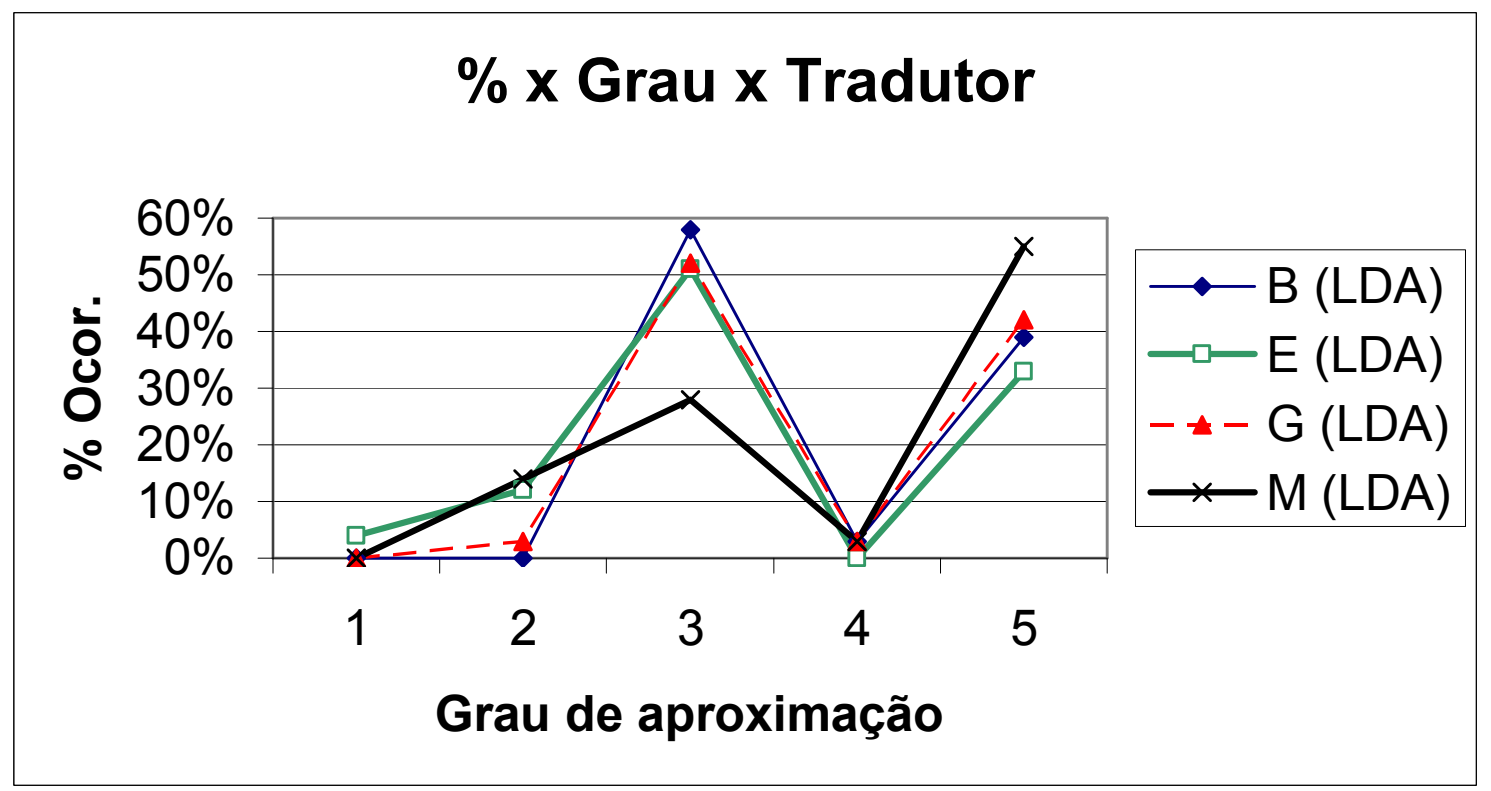

Figura 7.5 - Percentagem de ocorrência por grau por tradutor - corpus ing-br - tradutores B,

$$
E, G, \text { e } M
$$

Há uma certa uniformidade na abordagem utilizada pelos tradutores na figura 7.5, segundo a medida de percentagem de ocorrências para cada grau de aproximação. Todos utilizaram poucas soluções de graus 1 e 4 . Os dados para os tradutores B, E e G foram bastante semelhantes, e M favoreceu o grau 5 às custas do grau 3.

Os dados para o sentido contrário são apresentados na tabela 7.13. Observe o número maior de tradutores traduzindo de sua língua de domínio mais ativo.

\begin{tabular}{|c|c|c|c|c|c|c|c|c|c|}
\hline Grau & $\begin{array}{c}\text { D } \\
\text { (LDA) }\end{array}$ & E (não) & F (não) & H (não) & $\begin{array}{c}\text { K } \\
\text { (LDA) }\end{array}$ & L (LDA) & M (não) & P (LDA) & $\begin{array}{c}\text { Q } \\
\text { (LDA) }\end{array}$ \\
\hline 1 & $\mathbf{6 \%}$ & $\mathbf{7 \%}$ & - & $8 \%$ & - & $\mathbf{6 \%}$ & $\mathbf{1 1 \%}$ & - & - \\
\hline 2 & $\mathbf{7 \%}$ & $\mathbf{1 2 \%}$ & $6 \%$ & $8 \%$ & $13 \%$ & $\mathbf{6 \%}$ & $\mathbf{3 \%}$ & $13 \%$ & - \\
\hline
\end{tabular}




\begin{tabular}{|c|c|c|c|c|c|c|c|c|c|}
\hline 3 & $\mathbf{3 1 \%}$ & $\mathbf{3 5 \%}$ & $41 \%$ & $42 \%$ & $38 \%$ & $\mathbf{3 7 \%}$ & $\mathbf{3 5 \%}$ & $13 \%$ & $56 \%$ \\
\hline 4 & $\mathbf{1 5 \%}$ & $\mathbf{1 9 \%}$ & $6 \%$ & $25 \%$ & - & $\mathbf{3 3 \%}$ & $\mathbf{2 7 \%}$ & $25 \%$ & $11 \%$ \\
\hline 5 & $\mathbf{4 1 \%}$ & $\mathbf{2 8} \%$ & $47 \%$ & $17 \%$ & $50 \%$ & $\mathbf{1 9 \%}$ & $\mathbf{2 4 \%}$ & $50 \%$ & $33 \%$ \\
\hline $\begin{array}{c}\text { No. total } \\
\text { ex. }\end{array}$ & $\mathbf{6 8}$ & $\mathbf{4 3}$ & 17 & 12 & 8 & $\mathbf{5 4}$ & $\mathbf{3 7}$ & 8 & 9 \\
\hline No. docs & $\mathbf{5}$ & $\mathbf{2}$ & 2 & 1 & 1 & $\mathbf{6}$ & $\mathbf{3}$ & 1 & 1 \\
\hline
\end{tabular}

Tabela 7.13 - \% de ocorrência por grau por tradutor - corpus br-ing

Os dados para os tradutores do corpus br-ing seguiram dois perfis. O primeiro representa os tradutores D e E e os dados são exibidos na figura 7.6. O segundo representa os tradutores $\mathrm{H}$, L e M. Observe que não há uma tendência relacionada à tradução para a LDA do tradutor (ou não).

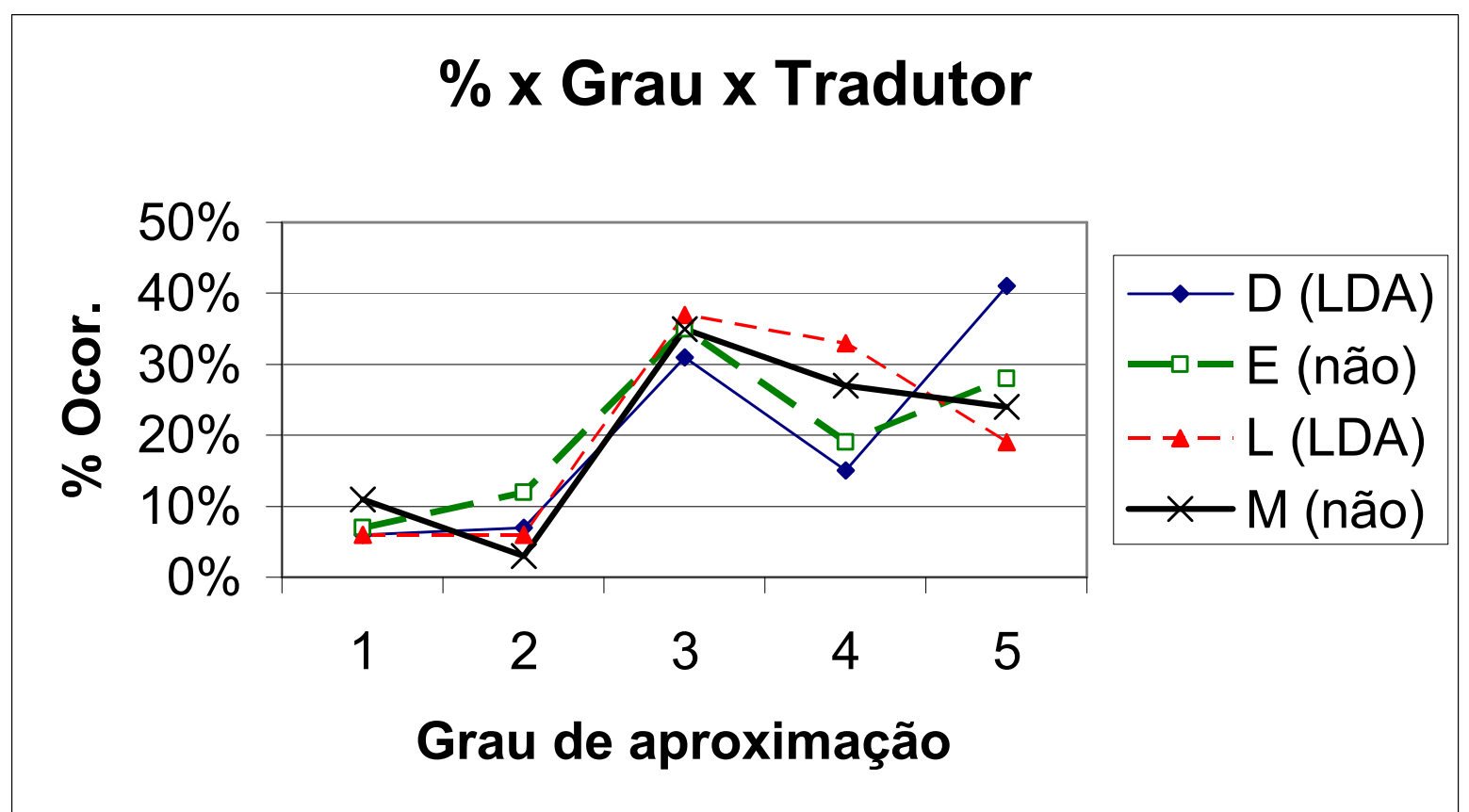

Figura 7.6 - \% de ocorrência por grau por tradutor - corpus br-ing - tradutores D, E, L e M 
O perfil dos tradutores D e E é semelhante ao perfil dos tradutores na figura 7.5. Os tradutores L e M, porém, representam um segundo perfil ou abordagem, com um número maior de soluções de graus 3 e 4 e números relativamente menores de grau 5. Procurei ver as situações tradutórias dos documentos traduzidos pelos 4 tradutores para ver se essas explicavam a diferença de perfil, mas todos os documentos do $\mathrm{L}$ foram $\mathrm{A} 1$ ou $\mathrm{C} 1$ e todos os documentos do $\mathrm{M}$ foram $\mathrm{C} 1$, exceto um caso que poderia ter sido $\mathrm{C} 1$, D1 ou D2. Os documentos dos tradutores D e E também foram A1 ou B1, com um documento (do tradutor D) com a situação D3. Vimos na figura 7.3 que as situações A1, B1, C1 e C2 têm perfis semelhantes, portanto as diferenças de tipos de situação tradutória não explicam as diferenças entre os tradutores $\mathrm{D}$ e $\mathrm{E}$ e os tradutores L e M.

\subsection{Análises de graus de aproximação e modalidades específicos}

Nesta seção focarei alguns aspectos especialmente interessantes dos dados: o uso de empréstimo junto com outras modalidades, a correspondência entre tradução literal e grau de aproximação, e a equivalência funcional.

\subsubsection{Empréstimo + outras modalidades}

Este estudo mostrou que há uma tendência forte de uso de empréstimo para a tradução de marcadores referenciais, especialmente quando o original contém uma sigla. Empréstimos puros representaram $4 \%$ das soluções tradutórias dos exemplos estudados, enquanto empréstimos empregados junto com outras modalidades representaram $11 \%$ das soluções tradutórias. Os tipos de modalidades empregados junto com empréstimo são detalhados na tabela 7.14, em ordem alfabética.

\begin{tabular}{|l|c|}
\hline \multicolumn{1}{|c|}{ Modalidade } & Ocorrências \\
\hline EMP & 18 \\
\hline EF-EMP-EX & 2 \\
\hline EF-EMP-EX-L & 2 \\
\hline EMP-EF-EX & 1 \\
\hline
\end{tabular}




\begin{tabular}{|l|c|}
\hline EMP-EF-EX-L-M & 1 \\
\hline EMP-EF-EX-M & 3 \\
\hline EMP-EO & 1 \\
\hline EMP-EO-EX & 2 \\
\hline EMP-EX & 1 \\
\hline EMP-EX-L & 16 \\
\hline EMP-EX-L-M & 2 \\
\hline EMP-EX-M & 3 \\
\hline EMP-L & 12 \\
\hline EMP-L-M & 2 \\
\hline EMP-L-T & 1 \\
\hline EMP-M-T & 1 \\
\hline Total & $\mathbf{6 8}$ \\
\hline
\end{tabular}

Tabela 7.14 - Modalidades com empréstimo nos dois corpora paralelos

\subsubsection{Tradução literal vs. grau de aproximação}

No capítulo 3, esbocei quais modalidades freqüentemente coincidem com quais graus de aproximação. Não há uma classificação ou regra absoluta, pois a modalidade foca o processo e o produto, enquanto o grau de aproximação foca o produto. Em muitos casos, seria possível identificar o grau de aproximação através da tradução sem consultar o orginal.

A tradução literal é uma das modalidades mais versáteis. A figura 7.7 mostra a distribuição de tradução literal entre os graus de aproximação para os exemplos deste estudo. 


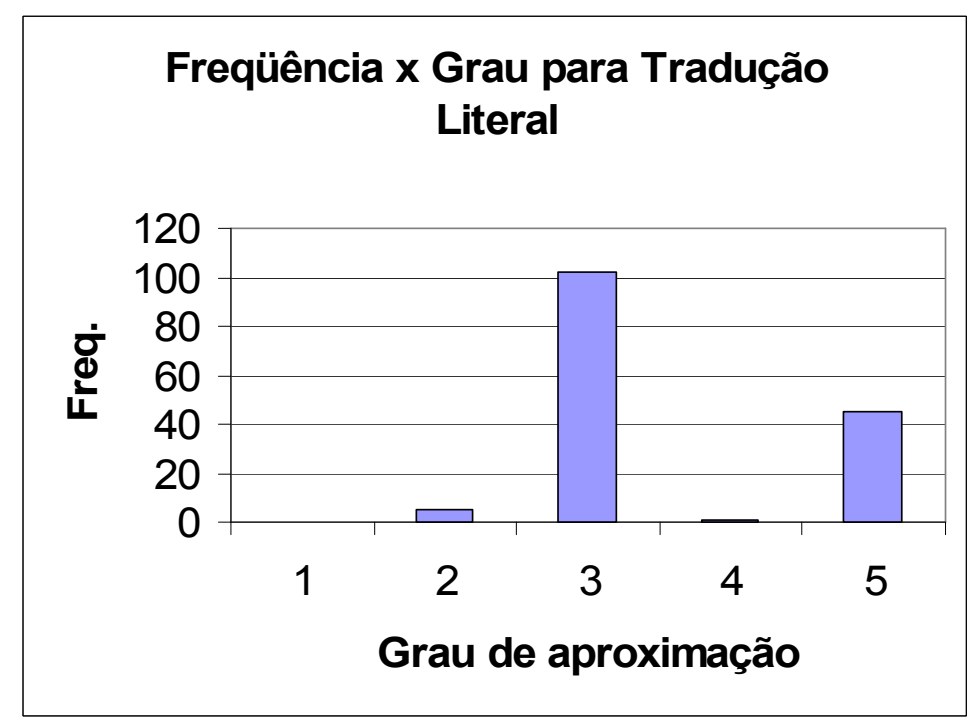

Figura 7.7 - Freqüência de ocorrência por grau para tradução literal

Os poucos casos de grau 4 foram situações em que o original não continha um sinal de alteridade, como o nome do país. As soluções de grau 5 foram as situações felizes em que a tradução literal de uma expressão ou termo em um idioma resultava em uma expressão ou termo já comum no idioma de chegada. Este foi o caso com a tradução de "good faith" para "boa-fé" e o contrário. Os casos de traduções de grau 2 foram quase decalques, e não houve soluções de grau 1. Como esperado (baseado na definiç̧ão dos graus no capítulo 3), a grande maioria se encaixou no grau 3 de aproximação.

\subsection{Outra maneira de apresentar as modalidades}

Na seção 7.1, apresentei a freqüência de ocorrência das modalidades segundo as 25 categorias definidas na seção 4.5.5. Porém, a maioria dos outros estudos descritivos que empregou modalidades para descrever soluções tradutórias utilizou a palavra como a unidade de estudo. Não seria possível fazer alterar a unidade de estudo sem revisitar todos os exemplos (e a análise seria outra). Porém, para fins de comparação, calculei as percentagens segundo outro critério. Quando uma unidade de estudo foi traduzida pela combinação de modalidades D-EXL (por exemplo), tratei-a como se fosse um exemplo de tradução através de decalque, outro através de explicitação e outro através de tradução literal. Dessa maneira, não há diferença 
entre duas modalidades empregadas juntamente para traduzir a mesma unidade de estudo e as duas modalidades empregadas separadamente para traduzir duas unidades diferentes. Os resultados desse cálculo alternativo são apresentados na tabela 7.15.

\begin{tabular}{|l|c|c|}
\hline Modalidade & Ocorrências & $\begin{array}{c}\text { Percentual } \\
\text { (sobre 473) }\end{array}$ \\
\hline Correção & 6 & $1,3 \%$ \\
\hline Decalque & 16 & $3,4 \%$ \\
\hline Eq. Cultural & 1 & $0,2 \%$ \\
\hline Eq. Discursiva & 46 & $9,7 \%$ \\
\hline Eq. Funcional & 33 & $7,0 \%$ \\
\hline Empréstimo & 71 & $15,0 \%$ \\
\hline Eq. Operacional & 34 & $7,2 \%$ \\
\hline Erro & 10 & $2,1 \%$ \\
\hline Explicitação & 47 & $9,9 \%$ \\
\hline Implicitação & 12 & $2,5 \%$ \\
\hline Literal & 215 & $45,5 \%$ \\
\hline Modulação & 70 & $14,8 \%$ \\
\hline ME (especif.) & 1 & $0,2 \%$ \\
\hline MG (general.) & 11 & $2,3 \%$ \\
\hline MP (parte) & 16 & $3,4 \%$ \\
\hline MT (todo) & 6 & $1,3 \%$ \\
\hline Omissão & 11 & $2,3 \%$ \\
\hline Transcrição & 12 & $2,5 \%$ \\
\hline
\end{tabular}

Tabela 7.15 - Freqüencia de Ocorrência de cada modalidade tomada separadamente

Observe que as percentagens não somam a $100 \%$, pois o número de unidades de estudo (o denominador do cálculo) foi mantido. Esta maneira de calcular as percentagens é semelhante 
ao método utilizado por Matthews (2003), mencionado na introdução (capítulo 1). Observe que o que ela chama de "equivalência" seria semelhante às modalidades "equivalência discursiva" e "equivalência operacional" deste estudo, e não com a soma dos três tipos de equivalência.

Juntando estes dois tipos de equivalência em uma categoria, juntando todas as modulações e outras equivalências em outra categoria, e juntando os resultados para tradução literal e transposição (pois o estudo de Matthews diferencia entre elas e este estudo não), é possível comparar os resultados em uma primeira aproximação.

\begin{tabular}{|l|c|c|c|}
\hline $\begin{array}{l}\text { Procedimento } \\
\text { (Matthews, 2003) }\end{array}$ & Inglês para francês & $\begin{array}{c}\text { Inglês para } \\
\text { espanhol }\end{array}$ & $\begin{array}{c}\text { Este estudo (inglês } \\
\text { /português) }\end{array}$ \\
\hline Equivalência & $45 \%$ & $26 \%$ & $17 \%$ \\
\hline Modulação & $80 \%$ & $18 \%$ & $29 \%$ \\
\hline $\begin{array}{l}\text { Tradução Literal ou } \\
\text { Transposição }\end{array}$ & $57 \%$ & $104 \%$ & $46 \%$ \\
\hline
\end{tabular}

Tabela 7.16 - Comparação com os dados de Matthews (2003)

O que os dados da tabela 7.16 mostram, mais do que qualquer outra coisa, é que a escolha dos trechos para estudar faz uma diferença enorme nos resultados.

Os outros estudos citados na introdução são baseados no modelo de Aubert (1984, 1998, 2005a). A unidade de estudo foi a palavra nesses casos, e todas as palavras foram analisadas. Apesar das diferenças, há uma correspondência entre as modalidades utilizadas neste estudo e as utilizadas nos estudos de Zanotto (1993) e Camargo (1998). Estes estudos são descritos em mais detalhes na seção 1.3 deste estudo. Este estudo juntou tradução literal e transposição em uma modalidade chamada "tradução literal". Todos os tipos de modulação e equivalência deste estudo se encaixam na modalidade "modulação" de Aubert. Os dados são apresentados no formato das modalidades de Aubert (2005a) na tabela 7.17, junto com os resultados de 
Zanotto (1993) e de Camargo (1998), ambos para textos jurídicos. Nem todas as modalidades são apresentadas na tabela e nem todas as modalidades são exatamente as mesmas, mas é uma primeira aproximação.

\begin{tabular}{|l|c|c|c|}
\hline \multicolumn{1}{|c|}{ Modalidade } & $\begin{array}{c}\text { Este estudo } \\
(\text { sobre 473) }\end{array}$ & $\begin{array}{c}\text { Zanotto } \\
(1993)\end{array}$ & $\begin{array}{c}\text { Camargo } \\
(1998)\end{array}$ \\
\hline Empréstimo & $15,0 \%$ & $3,7 \%$ & $3,4 \%$ \\
\hline Explicitação & $9,9 \%$ & $12,0 \%$ & n.a. \\
\hline Tradução Literal (mais transposição) & $45,5 \%$ & $68,3 \%$ & $64,1 \%$ \\
\hline Modulação (mais equivalências) & $46,0 \%$ & $14,7 \%$ & 23,4 \\
\hline Omissão & $2,3 \%$ & $0,3 \%$ & n.a. \\
\hline
\end{tabular}

Tabela 7.17 - Dados deste estudo segundo as categorias de Aubert (2005a)

As diferenças entre os resultados deste estudo e os resultados de Zanotto e Camargo são principalmente devido à diferença entre os tipos de unidade de estudo. Este estudo analisou somente marcadores culturais, e os estudos acima citados analisaram todas as palavras no texto. As diferenças principais - mais modulação, mais empréstimo, mais explicitação e menos tradução literal-foram esperadas, por serem os tipos de modalidades empregados quando o tradutor enfrenta um marcador cultural.

\subsection{Resumo das conclusões}

O objetivo do estudo foi estudar as soluções tradutórias uma a uma, e procurar tendências em termos de modalidades (representando o processo tradutório) e em termos de graus de aproximação (representando o produto da tradução). As análises qualitativas forneceram uma vista de perto do processo tradutório, enquanto as análises quantitativas forneceram uma visão global da tradução jurídica. 


\subsubsection{Resumo das análises qualitativas}

Não percebi nenhuma tendência geral que se aplicasse conjuntamente a marcadores referenciais e estilísticos. Considerando cada tipo de marcador separadamente, como mostrado na figura 7.1, soluções de graus 2, 3 e 5 foram empregadas para marcadores estilísticos, com aproximadamente $50 \%$ de grau $5,40 \%$ de grau 3 e o restante de grau 2 . Soluções de todos os graus foram empregados para marcadores referenciais, com aproximadamente $40 \%$ de grau 3, 30\% de grau 5, 20\% de grau 4 e o restante de graus 1 e 2 .

As tendências se mostram, porém, na análise por categoria. $\mathrm{Na}$ tradução de tipos de sociedades e outras pessoas jurídicas (seção 5.1), a maioria das soluções é de grau 3 (quase $40 \%$ ) e $20 \%$ são de grau 5. As soluções de grau 3 foram traduções literais e modulações, enquanto as de grau 5 foram equivalências operacionais e modulações.

$\mathrm{Na}$ tradução de documentos constitutivos (seção 5.2), dois terços das soluções são de grau 5 e um terço são de grau 3, com uma única solução de grau 4. As soluções de grau 3 são principalmente equivalências funcionais (um dos poucos usos deste tipo de equivalência) com algumas modulações, e as soluções de grau 5 são principalmente modulações.

Na tradução de conceitos jurídicos (seção 5.3), cerca de 50\% das soluções são de grau 3, e cerca de $35 \%$ são de grau 5, com alguns casos dos outros três graus. As soluções de grau 3 são principalmente literais (quase metade) com modulação (mais um terço) e uma mistura de outras modalidades. As soluções de grau 5 são também principalmente literais (um terço), equivalências operacionais (um quinto) e modulações de todos os tipos (mais um quinto).

$\mathrm{Na}$ tradução de conceitos financeiros (seção 5.4), há uma forte influência das traduções dos índices de mercado (cuja tradução é semelhante à tradução das qualificações). Cerca de 35\% das soluções são de grau 4, 20\% são de grau 3, e graus 1, 2 e 5 são responsáveis por 15\% cada. As soluções de grau 1 são todas empréstimos e as soluções de grau 2 são todas decalques. As soluções de grau 3 incluem 2 casos de equivalência funcional, e o restante são de empréstimo mais tradução literal (às vezes com uma terceira modalidade). Quase todas as 
soluções de grau 4 são empréstimo com uma outra modalidade (ou mais de uma), e as soluções de grau 5 incluem 3 casos de equivalência operacional, dois casos de transcrição e uma correção. O uso de empréstimo foi o que mais se destacou nessa área.

Na tradução de qualificações de pessoas físicas e jurídicas (seção 5.5), vemos a tendência já vista na seção 5.4 ainda mais forte, com quase todas as traduções do grau 4 e só um quinto das soluções (todas empréstimos puros) de grau 1. As soluções de grau 4 são quase todas empréstimos com uma outra modalidade (ou mais de uma).

Na tradução de arcaísmos na linguagem jurídica (seção 6.1), 60\% das soluções são de grau 5, com $20 \%$ de grau 2 e mais $20 \%$ de grau 3. As soluções de grau 2 são decalques e modulações, enquanto as soluções de grau 3 são 50\% modulações e 50\% outras modalidades (tradução literal e equivalências funcional e operacional). As soluções de grau 5 são na maioria equivalências discursivas, com quase $20 \%$ traduções literais em situações felizes nas quais a tradução literal resulta em uma expressão naturalmente presente na língua de chegada. Comparando os dois sentidos tradutórios, houve uma maior tendência para localização nas traduções para inglês.

Na tradução de binômios tautológicos, todas as traduções se encaixaram no grau 3 (36\%) e no grau $5(64 \%)$. A maioria das traduções foi literal para os dois graus, com equivalências discursivas representando $21 \%$ das soluções de grau 5 . O grau 5 ocorre quando a expressão (na tradução) é naturalmente presente na língua de chegada.

$\mathrm{Na}$ tradução de binômios não tautológicos, a percentagem de traduções de grau 3 subiu para $62 \%$ (principalmente traduções literais). Das soluções de grau 5 (32\% do total), 50\% também foram traduções literais e as outras soluções foram equivalências e modulações.

Portanto, a solução tradutória depende muito do tipo de problema, da proximidade dos dois idiomas no caso de marcadores estilísticos e da proximidade dos conceitos jurídicos no caso de marcadores referenciais. Em vez de uma tendência forte para a localização ou para a 
neutralidade ao longo de um documento, a decisão parece ser tomada em uma abordagem "caso-a-caso".

\subsubsection{Resumo das análises quantitativas}

Em resumo, comparado com estudos que analisaram todas as palavras de um texto (e não somente os marcadores culturais), este estudo mostrou que estes marcadores são responsáveis por uma percentagem maior de emprego de equivalências, modulações, explicitações e empréstimos. Esses dados são detalhados na tabela 7.3.

Os tipos de modalidades empregadas e os graus de aproximação resultantes foram diferentes para marcadores referenciais e marcadores estilísticos. Os marcadores estilísticos foram traduzidos de uma maneira compatível com os graus 3 e 5 (com algumas poucas soluções de grau 2), enquanto os marcadores referenciais foram traduzidos de uma maneira compatível com todos os graus de aproximação, especialmente os graus 3, 5 e 4 (nessa ordem de preferência). Esses resultados são apresentados na figura 7.1.

A classificação dos exemplos por grau de aproximação foi analisada para os dois sentidos tradutórios, inglês para português e o contrário. Estes dados são apresentados nas tabelas $7.5 \mathrm{e}$ 7.6 acima e na figura 7.8 abaixo. 


\section{\% de Ocorrência x Grau x Sentido Tradutório}

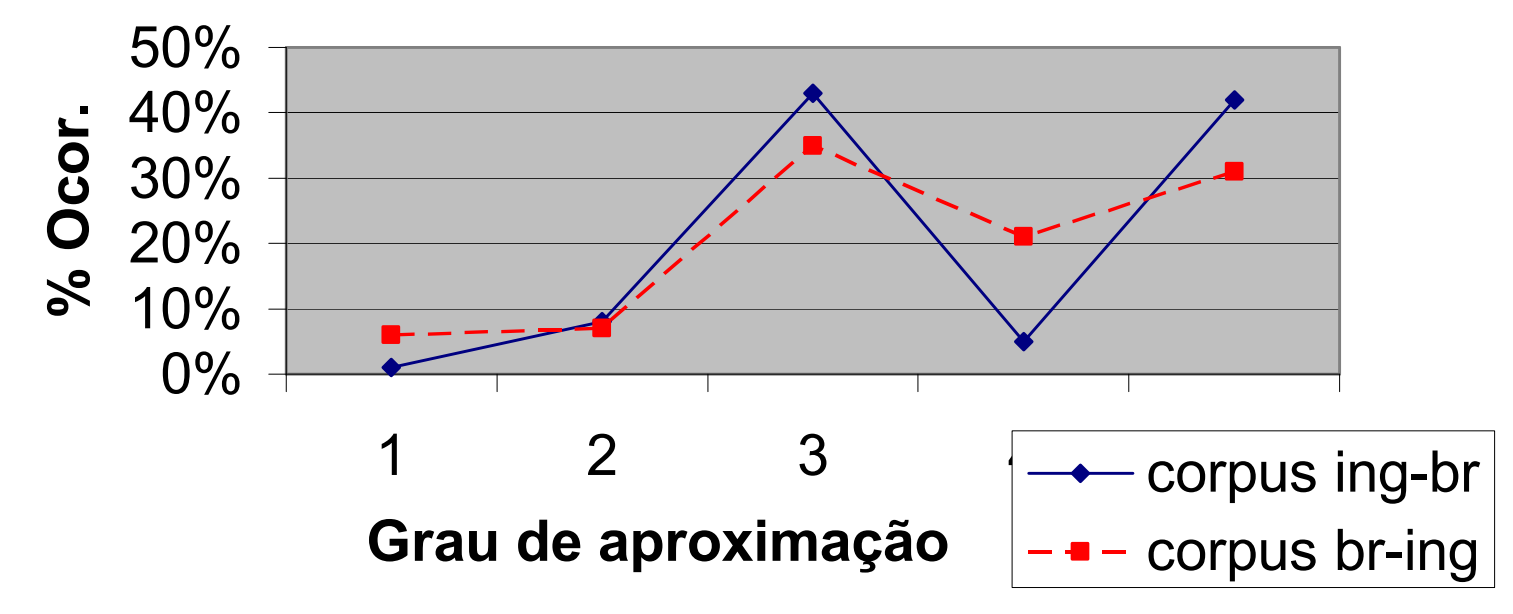

Figura 7.8 - \% de ocorrência por grau por sentido

As traduções de documentos brasileiros para o inglês mostram uma tendência mais forte para a alteridade, $16 \%$ a mais do que as traduções para o português. $\mathrm{O}$ número de empréstimos também é maior. As diferenças são devidas aos marcadores referenciais, pois os resultados para os marcadores estilísticos são quase idênticos.

O levantamento das diferenças entre as percentagens de cada grau de aproximação para traduções juramentadas e não juramentadas mostra uma leve preferência para soluções de grau 4 em documentos não juramentados nos dois sentidos. Os valores absolutos, porém, são muito diferentes para tradução para inglês (18\% das soluções de grau 4 em documentos juramentados e $22 \%$ das soluções em documentos não juramentados) e para tradução para português ( $2 \%$ das soluções de grau 4 em documentos juramentados e $8 \%$ das soluções em documentos não juramentados). Esta diferença absoluta provavelmente vem da diferença entre os corpora ing-br e br-ing, detalhada acima. Estes dados são apresentados nas tabelas 7.8 e 7.9 . 
As diferenças entre as percentagens de cada grau de aproximação para traduções feitas para a LDA do tradutor e da LDA do tradutor também foram levantadas. Apenas os dados para o corpus br-ing foram analisados devido à falta de dados suficientes no outro sentido tradutório. Essa análise (por língua de domínio mais ativo) não foi prevista no planejamento do corpus, e é feita aqui apenas para aproveitar todos os parâmetros disponíveis. Houve pouca diferença nas percentagens de/para a LDA, com a maior diferença igual a 5\% para o grau 5 (percentagem maior em traduções para a LDA) e uma diferença de 3\% para o grau 3 (percentagem menor em traduções para a LDA). Estas diferenças provavelmente não são significativas.

Em termos de situações tradutórias, os dados se comportaram de duas maneiras. As situações A1, B1, C1 e C2 mostraram o perfil apresentado na figura 7.3, acima, e as situações A2, D2 e D3 mostraram o perfil apresentado na figura 7.4. A diferença principal entre estes dois perfis foi a percentagem muito maior de soluções de grau 5 para as situações A2, D2 e D3, correspondente a uma abordagem de localização do documento original para a língua/país de chegada.

Os dados de grau de aproximação foram compilados por tradutor por sentido tradutório, mas devido ao grande número de tradutores e o número pequeno de documentos contribuídos por cada um, os dados foram esparsos e não foi possível comparar seus estilos com muita precisão. Como os dados não são uniformes (não temos uma tradução juramentada e uma não juramentada de cada tradutor, não temos uma tradução para a LDA e uma não para a LDA de cada tradutor, etc.) em alguns casos um documento de um dado tipo pode influenciar os dados do tradutor (especialmente quando há poucos documentos daquele tradutor). Com esses receios, comparei as percentagens de ocorrência apenas para os tradutores que contribuíram mais de 30 exemplos ou pelo menos 3 documentos. Os perfis são apresentados nas figuras 7.5 e 7.6. 
Estes resultados quantitativos, enquanto não conclusivos - especialmente devido ao tamanho do corpus e suas características — podem contribuir para orientar a coleta de corpora jurídicos no futuro.

\subsubsection{Sugestões para trabalhos futuros}

Seria muito difícil conseguir mais documentos para o corpus sem pagar para as traduções (apresentar o original como se fosse um trabalho normal e pagar o colega o preço de mercado para a tradução). Por questões de confidencialidade e até receio de ser analisado e comparado com outros tradutores, mesmo que no anonimato, foi muito difícil coletar os documentos dos corpora paralelos. Considero os corpora esgotados ou quase esgotados para a análise de marcadores culturais, mas seriam uma bela fonte para o estudo de verbos no universo jurídico, especialmente na linguagem de execução (p.ex. Seller grants, Purchaser acknowledges), a linguagem de obrigação (p.ex. Company shall purchase, Company must sell), a linguagem de discrição (p.ex. Party may purchase. Company is authorized to sell) e a linguagem de proibição (p.ex. Company shall not purchase, Company must not sell). Os corpora também seriam um bom recurso para o estudo da maneira de declarar e traduzir o conceito de prazo, ubíquo na linguagem jurídica.

Creio que os corpora comparáveis seriam uma boa fonte de exemplos para estudos lingüísticos de qualquer natureza, tanto de terminologia da área jurídica quanto dos idiomas em questão em geral. Foram subutilizados nesse estudo devido à natureza das análises. Eles também poderiam ser utilizados para estudar verbos e prazos como mencionado acima.

Um estudo de traduções médicas, especialmente protocolos para estudos clínicos, também seria muito interessante. $\mathrm{O}$ esquema de graus de aproximação teria de ser alterado, pois o grau 4 (alteridade) seria pouco utilizado nesse contexto. Porém, um outro esquema relacionado a registro seria muito interessante, pois há situações em que existem dois registros (um entre profissionais médicos e outro entre estes e pacientes) para um dado termo em um idioma, porém há apenas uma solução tradutória no outro idioma. 
O material relacionado ao direito no segundo capítulo seria uma boa base para a confecção de um estudo terminológico bilíngüe na área de direito privado, pois os dicionários atualmente disponíveis no mercado apenas listam termos e fornecem uma ou no máximo duas traduções, sem definições ou uma idéia do raciocínio utilizado para chegar àquela tradução. 


\section{Referências Bibliográficas}

301 Legal Forms, Letters and Agreements. Londres: Lawpack Publishing Ltd. 2002. CDROM v. 6.1.

ADAMS, KENNETH A. Legal usage in drafting corporate agreements. Westport, Conn.: Quorum Books, 2001. ISBN: 1-56720-410-4

ALVES, WILMA RODRIGUES. Tradução juramentada e marcadores culturais: uma questão de dizibilidade. Dissertação (Mestrado). São Paulo, FFLCH/USP, 2005.

AUBERT, F.H. "Descrição e quantificação de dados em tradutologia". Tradução e Comunicação, n. ${ }^{\circ}$ 4. São Paulo, Álamo, 1984.

AUBERT, F. H. Modalidades de tradução: teoria e resultados. TradTerm 5.1. São Paulo, CITRAT/FFLCH/USP, 1998. p. 99-128.

AUBERT, F.H. As variedades de empréstimos. DELTA: Documentação de Estudos em Lingüística Teórica e Aplicada, São Paulo, v. 19, p. 27-42, 2003.

AUBERT, F.H. Lingüística e Tradução: A Tradução como Subsídio para os Estudos Lingüísticos Constrativos. São Paulo, FFLCH, USP, $1^{\circ}$ semestre de 2005a. Anotações do curso.

AUBERT, F.H. Dilemas da literalidade na tradução juramentada. Trabalhos em Lingüística Aplicada vol. 44 (2). IEL, Unicamp. 2005b. p. 247-263. ISSN: 0103-1813.

BARBOSA, H. G. Procedimentos técnicos da tradução. 2. ed. Campinas, Pontes, 2004. 
BOWKER, LYNNE, PEARSON, JENNIFER. Working with Specialized Language: a practical guide to using corpora. London: Routledge, 2002. ISBN: 0-415-23699-1

CAMARGO, ANDRÉ ANTUNES SOARES DE. Vocabulário jurídico do direito de empresa no novo código civil brasileiro. Confluências - Revista de Tradução Científica e Técnica. No. 1, Novembro, 2004. pp. 99-104. ISSN 1645-9350. Disponível em: $<$ www.confluencias.net>. Acesso em: 27 set. 2006.

CAMARGO, D. C. de (1993). As modalidades tradutórias e a tipologia textual: uma via de abordagem para uma tipologia da tradução interlingual. Tese (doutorado). São Paulo, FFLCH/USP.

CAMARGO, D.C. Aproximações e distanciamentos entre os textos jurídico, técnico, corporativo e jornalístico sob a ótica das modalidades tradutórias. In: VII Encontro Nacional de Tradutores e I Encontro Internacional de Tradutores. Anais... ABRAPT/Universidade de São Paulo, 1998.

CHILD, BARBARA. Drafting Legal Documents: Principles and Practices, 2nd ed. St. Paul, Minnesota: West Group, 1992. ISBN: 0-314-00325-8

COSTA, PEDRO CORAL. A tradução de inglês para português de documentos constitutivos de sociedades. Confluências - Revista de Tradução Científica e Técnica. No. 2, Maio, 2005. pp. 6-27. ISSN 1645-9350. Disponível em: <www.confluencias.net>. Acesso em: 27 set. 2006.

DINIZ, MARIA HELENA. Dicionário Jurídico, 2. ed. revisada. São Paulo: Editora Saraiva, 2005. ISBN: 85-02-02748-4

FAZZIO JUNIOR, WALDO. Manual de direito comercial, 4. ed.São Paulo: Editora Atlas, 2004. 
FIUZA, RICARDO. Novo Código Civil Comentado. 5. edição atualizada. São Paulo: Ed. Saraiva, 2006.

GARNER, BRYAN A. A Dictionary of Modern Legal Usage, 2nd ed. Oxford: Oxford University Press, 1995.

GARNER, BRYAN A. Black's Law Dictionary, 7th ed. St. Paul, Minnesota: West Group, 1999.

GLENDON, M.A., GORDON, M.W.,CAROZZA, P.G. Comparative Legal Traditions in a Nutshell. 2nd ed. St. Paul, Minn: West Group, 1999.

HENRIQUES, ANTONIO; MARIA MARGARIDA DE ANDRADE. Dicionário de verbos jurídicos, 3. ed. São Paulo: Atlas, 1999.

HOLMES, JAMES S. The name and nature of translation studies. In: Venuti, L. (Ed.) The Translation Studies Reader, London/New York: Routledge, 2000.

HOLZ-MÄNTTÄRI， J. Translatorisches Handeln: Theorie und Methode, Helsinki; Suomalainen Tiedeakatemia, 1984, In MUNDAY, JEREMY. Introducing Translation Studies: Theories and Applications. London: Routledge, 2001.

HOUAISS, ANTÔNIO; VILLAR, MAURO DE SALLES. Dicionário Houaiss da Língua Portuguesa, Rio de Janeiro: Objetiva, 2001.

KEENAN, DENIS; RICHES, SARAH. Business Law, 6th ed. Harlow, England: Longman, 2002. 
KLAUDY, KINGA; KÁROLY, KRISZTINA. "Implicitation in translation: An empirical justification of operational asymmetry in translation". In: 10th International Conference on Translation and Interpreting, Translation Targets, 11 - 13 September 2003. Citado por PYM, ANTHONY, "Explaining Explicitation". New Trends in Translation Studies. In Honour of Kinga Klaudy. ed. Krisztina Károly. Budapest, 2005. Version 2.2.

MALMKJÆR, KIRSTEN. "Who Can Make Nice a Better Word than Pretty?: Collocation, Translation and Psycholinguistics". BAKER et al. (Ed.) 1993; pp 213-232 Citado por BAKER, MONA. "Corpora in Translation Studies: An Overview and Some Suggestions for future Research". Target v. 7, 223-243, 1995. John Benjamins B.V. Amsterdam.

MARTINS, SERGIO PINTO. Instituições de Direito Público e Privado. 6. ed. São Paulo: Ed. Atlas, 2006.

MATTHEWS, GLADYS GONZÁLEZ. L'Equivalence en Traduction Juridique: Analyse des traductions au sein de l'Accord de Libre-Échange Nord-Américain (ALENA). Tese (Doutorado). Faculté des Lettres, Université Laval, Québec, Canadá, 2003.

MELLO, MARIA CHAVES DE. Dicionário jurídico português-inglês-inglês-português, 7. ed. Rio de Janeiro: Elfos, 1998.

MUNDAY, JEREMY. Introducing Translation Studies: Theories and Applications. London: Routledge, 2001.

NEWMARK, PETER. A Textbook of Translation.London: Prentice Hall, 1988.

ORGANIZATION OF AMERICAN STATES. Inter-American Convention on Personality and Capacity of Juridical Persons in Private International Law. Disponível em: $<$ http://www.oas.org/juridico/english/treaties/b-49.htm> Acesso em: 4 out. 2006. 
PARIZATTO, JOÃO ROBERTO. Manual de prática dos contratos. São Paulo: Edipa, 2006.

PLÁCIDO E SILVA Vocabulário Jurídico. 22. ed. Rio de Janeiro: Forense [200?].

ROBERSON, CLIFF. The Complete Book of Business Forms and Agreements. New York: McGraw-Hill, 1994.

ROBINSON, DOUGLAS. Western Translation Theory: from Herodotus to Nietzsche. 2nd Ed. Manchester, UK: St. Jerome, 2002.

SALKIE, RAPHAEL. A new look at modulation, In Translation and Meaning, Part 5, 2001, p. $433-441$.

ŠARČEVIĆ, SUSAN. New Appoach to Legal Translation. Haia: Kluwer Law International, 1997, citado em Costa (2005), p. 23-24.

SAUSSURE, FERDINAND DE. Course in General Linguistics. Chicago: Open Court, 1986. (Tradução por Roy Harris de original em francês originalmente publicado em 1972.)

SCHLEIERMACHER, FRIEDRICH. Über die verschiedenen Methoden des Übersetzens (On the Different Methods of Translating). In ROBINSON, DOUGLAS. Western Translation Theory: from Herodotus to Nietzsche. 2nd Ed. Manchester, UK: St. Jerome, 2002.

STEINGOLD, FRED S. Legal Guide for Starting and Running a Small Business, 6th ed. Berkeley, California: Nolo, 1992.

TOURY, G. Descriptive translation studies and beyond. Tel Aviv: Benjamins translation library, 1995. 
VÁZQUEZ-AYORA, GERARDO. Introducción a la traductología: curso básico de traducción. Washington: Georgetown University Press, 1977.

VENUTI, L. The translator's invisibility. Londres: Routledge, 1995.

VERMONT SECRETARY OF STATE. Corporation Types. Disponível em: $<$ http://www.sec.state.vt.us/tutor/dobiz/TYPE.htm> Acesso em: 27 set. 2006.

VINAY, JEAN-PAUL, DARBELNET, JEAN-LOUIS. Stylistique comparée du français et de l'anglais. Nova edição corrigida. Paris: Didier, 1977.

ZANOTTO, P. F. Tipos de texto e modalidades de tradução. Tese (Doutorado). São Paulo, FFLCH/USP, 1993. 


\section{Apêndice}

Este apêndice contém um resumo dos exemplos (nem todo o texto mostrado nas grades dos capítulos 5 e 6 é mostrado aqui, para conservar espaço) com informações adicionais: um número de referência para o exemplo (consecutivo), o grau de aproximação, a(s) modalidade(s), se o documento foi juramentado ( $\mathrm{s}=\operatorname{sim}, \mathrm{n}=$ não) e a situação tradutória. A ordem da tabela imita a ordem dos exemplos nos capítulos de análise. A numeração consecutiva foi dividida nos casos de mais de uma unidade de estudo na mesma célula (pois aqui há apenas uma unidade de estudo por célula). Por exemplo, a linha 57 foi dividida em 57.1 e 57.2 .

\begin{tabular}{|c|c|c|c|c|c|c|c|c|}
\hline Seção & Ex. & Arquivo & Original & Tradução & Grau & Mod. & $\begin{array}{l}\text { Ju- } \\
\text { ram. }\end{array}$ & $\begin{array}{l}\text { Situ- } \\
\text { ação }\end{array}$ \\
\hline 5.1 .1 & 1 & co51_br-usD & sociedade anônima & corporationEO & 5 & EO & n & $\mathrm{A} 1 / \mathrm{B} 1$ \\
\hline 5.1 .1 & 1 & dc52_br-usD & sociedade anônima & corporationEO & 5 & EO & n & D3 \\
\hline 5.1 .1 & 1 & dc53_br-usnE & sociedade anônima & corporationEO & 5 & EO & n & A1 \\
\hline 5.1 .1 & 1 & dc54_br-usnE & sociedade anônima & corporationEO & 5 & EO & $\mathrm{s}$ & A1 \\
\hline \begin{tabular}{|l|}
5.1 .1 \\
\end{tabular} & 2 & dc51_br-usL & $\begin{array}{l}\text { sociedade por quotas de } \\
\text { responsabilidade limitada }\end{array}$ & $\begin{array}{l}\text { limited liability } \\
\text { companyEO }\end{array}$ & 5 & EO & n & A1 \\
\hline 5.1 .1 & 2 & dc54_br-usnE & $\begin{array}{l}\text { sociedade por quotas de } \\
\text { responsabilidade limitada }\end{array}$ & $\begin{array}{l}\text { limited liability } \\
\text { companyEO }\end{array}$ & 5 & EO & $\mathrm{s}$ & A1 \\
\hline \begin{tabular}{|l|}
5.1 .1 \\
\end{tabular} & 3 & dc52_br-usD & sociedade limitada & $\begin{array}{l}\text { limited liability } \\
\text { companyEO }\end{array}$ & 5 & $\mathrm{EO}$ & n & D3 \\
\hline \begin{tabular}{|l|}
5.1 .1 \\
\end{tabular} & 4 & dc52_br-usD & $\begin{array}{l}\text { sociedade limitada } \\
\text { brasileira }\end{array}$ & $\begin{array}{l}\text { limited liability } \\
\text { companyEO-O }\end{array}$ & 5 & EO-O & n & D3 \\
\hline \begin{tabular}{|l|}
5.1 .1 \\
\end{tabular} & 5 & dc52_br-usD & $\begin{array}{l}\text { sociedade limitada } \\
\text { brasileira }\end{array}$ & $\begin{array}{l}\text { Brazilian limited } \\
\text { liability companyL-EO }\end{array}$ & 4 & EO-L & n & D3 \\
\hline \begin{tabular}{|l|}
5.1 .1 \\
\end{tabular} & 6 & dc52_br-usD & $\begin{array}{l}\text { sociedade empresária } \\
\text { limitada }\end{array}$ & $\begin{array}{l}\text { limited liability } \\
\text { companyEO-O }\end{array}$ & 5 & EO-O & n & D3 \\
\hline \begin{tabular}{|l|}
5.1 .1 \\
\end{tabular} & 7 & dc54_br-usnE & $\begin{array}{l}\text { sociedade limitada } \\
\text { empresária }\end{array}$ & $\begin{array}{l}\text { limited liability } \\
\text { companyEO-O }\end{array}$ & 5 & EO-O & $\mathrm{s}$ & A1 \\
\hline
\end{tabular}




\begin{tabular}{|c|c|c|c|c|c|c|c|c|}
\hline 5.1 .1 & 8 & pr53_br-usnM & $\begin{array}{l}\text { sociedade por quotas de } \\
\text { responsabilidade limitada }\end{array}$ & $\begin{array}{l}\text { BrazilianEX limited } \\
\text { liability companyEO } \\
\text { [sociedade por quotas } \\
\text { de responsabilidade } \\
\text { limitada]EMP }\end{array}$ & 4 & $\begin{array}{l}\text { EMP- } \\
\text { EO-EX }\end{array}$ & $\mathrm{s}$ & $\mathrm{C} 1$ \\
\hline 5.1 .2 & 9 & dc53_br-usN & pessoa jurídica & legal entityM & 3 & $\mathrm{M}$ & $n$ & A1 \\
\hline 5.1 .2 & 9 & co53_br-usnF & pessoa jurídica & legal entityM & 3 & M & $\mathrm{s}$ & D2 \\
\hline 5.1 .2 & 10 & dc54_br-usnE & $\begin{array}{l}\text { geridos por } \\
\text { administradores, pessoas } \\
\text { naturais residentes no país }\end{array}$ & $\begin{array}{l}\text { managed by } \\
\text { administrators who } \\
\text { shall be resident in the } \\
\text { country < omissão> }\end{array}$ & 3 & $\mathrm{O}$ & $\mathrm{s}$ & A1 \\
\hline 5.1 .2 & 11 & pr3_us-brB & $\begin{array}{l}\text { a corporation organized } \\
\text { and existing in accordance } \\
\text { with the laws of }\end{array}$ & $\begin{array}{l}\text { sociedadeMG } \\
\text { constituída e existente } \\
\text { de acordo com as leis } \\
\text { de }\end{array}$ & 3 & MG & $\mathrm{s}$ & $\mathrm{C} 1 / \mathrm{D} 2$ \\
\hline 5.1 .2 & 12 & co3_us-brG & a corporation & sociedadeMG & 3 & $\mathrm{MG}$ & $\mathrm{N}$ & B1 \\
\hline 5.1 .2 & 13 & co11_us-brN & acorporation & sociedadeMG & 3 & MG & $\mathrm{N}$ & B1 \\
\hline 5.1 .2 & 14 & dc3_uk-brE & company & $\begin{array}{l}\text { sociedade } \\
\text { comercialMP }\end{array}$ & 5 & MP & $\mathrm{s}$ & C1 \\
\hline 5.1 .2 & 15 & dc54_br-usnE & sociedades simples & $\begin{array}{l}\text { non-enterpreneurial } \\
\text { companiesM }\end{array}$ & 2 & $\mathrm{M}$ & $\mathrm{s}$ & A1 \\
\hline 5.1 .3 & 16 & pr8_ukn-brH & company & sociedadeL & 3 & $\mathrm{~L}$ & n & D3 \\
\hline 5.1 .3 & 17 & dc2_uk-brB & $\begin{array}{l}\text { as a company } \\
\text { incorporated under the } \\
\text { laws }\end{array}$ & $\begin{array}{l}\text { como sociedadeL } \\
\text { constituída sob as leis }\end{array}$ & 3 & $\mathrm{~L}$ & $\mathrm{~s}$ & C1 \\
\hline 5.1 .3 & 18 & dc3_uk-brE & any company & qualquer sociedadeL & 3 & $\mathrm{~L}$ & S & $\mathrm{C} 1$ \\
\hline 5.1 .3 & 19.1 & dc54_br-usnE & sociedades, comerciais & $\begin{array}{l}\text { commercialL } \\
\text { companiesL }\end{array}$ & 2 & $\mathrm{~L}$ & $\mathrm{~s}$ & A1 \\
\hline 5.1 .3 & 19.2 & dc54_br-usnE & sociedades civis & civil companies & 2 & $\mathrm{~L}$ & S & A1 \\
\hline 5.1 .3 & 20 & dc1_us-brE & close corporation. & $\begin{array}{l}\text { sociedade de capital } \\
\text { fechadoEF. }\end{array}$ & 3 & EF & $\mathrm{s}$ & C1 \\
\hline 5.1 .4 & 21.1 & co2_us-brG & corporation & sociedade anônima & 5 & EO & $\mathrm{N}$ & B1 \\
\hline 5.1 .4 & 21.2 & co2_us-brG & partnership & sociedade & 5 & MG & $\mathrm{N}$ & B1 \\
\hline 5.1 .4 & 21.3 & co2 us-brG & organization & pessoa jurídica & 5 & $\mathrm{M}$ & $\mathrm{N}$ & $\mathrm{B} 1$ \\
\hline
\end{tabular}




\begin{tabular}{|c|c|c|c|c|c|c|c|c|}
\hline 5.1 .4 & 22.1 & co2_us-brG & of any person & de qualquer pessoaL & 3 & $\mathrm{~L}$ & $\mathrm{~N}$ & B1 \\
\hline 5.1 .4 & 22.2 & co2_us-brG & corporation & sociedade & 3 & MG & $\mathrm{N}$ & B1 \\
\hline 5.1 .4 & 22.3 & co2_us-brG & entity & entidade & 3 & $\mathrm{~L}$ & $\mathrm{~N}$ & B1 \\
\hline 5.1 .4 & 23.1 & pr4_ukn-brM & company & sociedade & 5 & $\mathrm{MG}$ & $\mathrm{s}$ & D2 \\
\hline 5.1 .4 & 23.2 & pr4_ukn-brM & corporation & $<$ omitido $>$ & 3 & $\mathrm{I}$ & $\mathrm{s}$ & D2 \\
\hline 5.1 .4 & 24.1 & dc4_uk-brE & company & empresa & 3 & $\mathrm{~L}$ & $\mathrm{~s}$ & $\mathrm{C} 1$ \\
\hline 5.1 .4 & 24.2 & dc4_uk-brE & partnership & parceria & 3 & $\mathrm{~L}$ & $\mathrm{~s}$ & $\mathrm{C} 1$ \\
\hline 5.1 .4 & 24.3 & dc4_uk-brE & joint venture & $\begin{array}{l}\text { empreendimento } \\
\text { conjunto }\end{array}$ & 2 & $\mathrm{~L}$ & $\mathrm{~s}$ & $\mathrm{C} 1$ \\
\hline 5.1 .4 & 24.4 & dc4_uk-brE & trust & fidúcia & 3 & $\mathrm{~L}$ & $\mathrm{~s}$ & $\mathrm{C} 1$ \\
\hline 5.1 .4 & 24.5 & dc4_uk-brE & enterprise & empreendimento & 3 & $\mathrm{~L}$ & $\mathrm{~s}$ & $\mathrm{C} 1$ \\
\hline 5.1 .4 & 25.1 & dc4_uk-brE & individual & Indivíduo & 3 & $\mathrm{~L}$ & $\mathrm{~s}$ & $\mathrm{C} 1$ \\
\hline 5.1 .4 & 25.2 & dc4_uk-brE & corporation & pessoa jurídica & 3 & MG & $\mathrm{s}$ & $\mathrm{C} 1$ \\
\hline 5.1 .4 & 25.3 & dc4_uk-brE & trust & fidúcia & 3 & $\mathrm{~L}$ & $\mathrm{~s}$ & $\mathrm{C} 1$ \\
\hline 5.1 .4 & 25.4 & dc4_uk-brE & $\begin{array}{l}\text { estate of a deceased } \\
\text { individual }\end{array}$ & $\begin{array}{l}\text { espólio de um indivíduo } \\
\text { falecido }\end{array}$ & 3 & $\mathrm{~L}$ & $\mathrm{~s}$ & $\mathrm{C} 1$ \\
\hline 5.1 .4 & 25.5 & dc4_uk-brE & partnership & parceria & 3 & $\mathrm{~L}$ & S & $\mathrm{Cl}$ \\
\hline 5.1 .4 & 25.6 & dc4_uk-brE & $\begin{array}{l}\text { unincorporated } \\
\text { association of persons. }\end{array}$ & $\begin{array}{l}\text { associação não } \\
\text { constituída de pessoas }\end{array}$ & 2 & $\mathrm{~L}$ & $\mathrm{~s}$ & $\mathrm{C} 1$ \\
\hline 5.1 .4 & 26.1 & dc2_uk-brB & private corporation & empresa privada & 3 & MG & s & $\mathrm{C} 1$ \\
\hline 5.1 .4 & 26.2 & dc2_uk-brB & public corporation & empresa estatal & 5 & $M$ & S & $\mathrm{C} 1$ \\
\hline 5.1 .4 & 26.3 & dc2_uk-brB & semi-public corporation & $\begin{array}{l}\text { empresa de economia } \\
\text { mista }\end{array}$ & 5 & M-MG & $\mathrm{s}$ & $\mathrm{C} 1$ \\
\hline 5.1 .4 & 26.4 & dc2_uk-brB & juridical person & pessoa jurídica & 3 & $\mathrm{~L}$ & $\mathrm{~s}$ & $\mathrm{C} 1$ \\
\hline 5.1 .4 & 27.1 & dc2_uk-brB & corporation & sociedade & 3 & MG & $\mathrm{s}$ & $\mathrm{C} 1$ \\
\hline 5.1 .4 & 27.2 & dc2_uk-brB & juridical persons & pessoa jurídica & 3 & $\mathrm{~L}$ & $\mathrm{~s}$ & $\mathrm{C} 1$ \\
\hline 5.1 .4 & 28.1 & dc2_uk-brB & company & outra sociedade & 3 & $\mathrm{~L}$ & $\mathrm{~s}$ & $\mathrm{C} 1$ \\
\hline 5.1 .4 & 28.2 & dc2_uk-brB & partnership & $\begin{array}{l}\text { sociedade em } \\
\text { comandita ou em nome } \\
\text { coletivo }\end{array}$ & 5 & EO & s & $\mathrm{C} 1$ \\
\hline 5.1 .4 & 28.3 & dc2_uk-brB & joint venture & "joint venture" & 3 & EMP & $\mathrm{s}$ & $\mathrm{C} 1$ \\
\hline 5.1 .4 & 28.4 & dc2_uk-brB & trust & $\begin{array}{l}\text { sociedade de negócios } \\
\text { fiduciários ["trust"] }\end{array}$ & 4 & $\begin{array}{l}\text { EF- } \\
\text { EMP }\end{array}$ & S & $\mathrm{C} 1$ \\
\hline 5.1 .4 & 28.5 & dc2_uk-brB & enterprise & empresa & 3 & $M$ & S & $\mathrm{C} 1$ \\
\hline
\end{tabular}




\begin{tabular}{|c|c|c|c|c|c|c|c|c|}
\hline 5.1 .4 & 29.1 & dc54_br-usnE & autarquias & agencies & 3 & MG & $\mathrm{s}$ & A1 \\
\hline 5.1 .4 & 29.2 & dc54_br-usnE & $\begin{array}{l}\text { sociedades de economia } \\
\text { mista }\end{array}$ & $\begin{array}{l}\text { mixed capital } \\
\text { companies }\end{array}$ & 3 & $\mathrm{~L}$ & $\mathrm{~S}$ & A1 \\
\hline 5.1 .4 & 29.3 & dc54_br-usnE & entidades paraestatais & parastate companies & 2 & D-M & $\mathrm{S}$ & A1 \\
\hline 5.1 .4 & 30.1 & dc3_uk-brE & company & sociedade comercial & 5 & MP & S & $\mathrm{C} 1$ \\
\hline 5.1 .4 & 30.2 & dc3_uk-brE & corporation & sociedade anônima & 5 & EO & $\mathrm{s}$ & $\mathrm{C} 1$ \\
\hline 5.1 .4 & 31.1 & co50_br-usL & pessoa jurídica & business entityEF & 3 & $\mathrm{EF}$ & $\mathrm{N}$ & B1 \\
\hline 5.1 .4 & 31.2 & co50_br-usL & entidade legal & legal entity & 3 & $\mathrm{~L}$ & $\mathrm{~N}$ & B1 \\
\hline 5.1 .4 & 32.1 & dc52_br-usD & pessoa física & individual & 3 & $\mathrm{~L}$ & n & D3 \\
\hline 5.1 .4 & 32.2 & dc52_br-usD & pessoa jurídica & entity & 3 & $\mathrm{M}$ & n & D3 \\
\hline 5.1 .4 & 33.1 & co59_br-usL & pessoa física & individual & 3 & $\mathrm{~L}$ & n & B1 \\
\hline 5.1 .4 & 33.2 & co59_br-usL & pessoa jurídica & business & 3 & $M$ & n & B1 \\
\hline 5.2 .1 & 1 & co5_us-brJ & articles of incorporation & atos constitutivosEF & 3 & $\mathrm{EF}$ & $\mathrm{N}$ & D3 \\
\hline 5.2 .1 & 2 & dc1_us-brE & $\begin{array}{l}\text { ARTICLES OF } \\
\text { INCORPORATION }\end{array}$ & $\begin{array}{l}\text { ATOS } \\
\text { CONSTITUTIVOSEF }\end{array}$ & 3 & EF & $\mathrm{s}$ & $\mathrm{C} 1$ \\
\hline 5.2 .1 & 3 & pr8_ukn-brH & articles of association & contrato social & 5 & MT & n & D3 \\
\hline 5.2 .1 & 4 & co2_us-brG & charter or bylaws & atos constitutivosEF & 3 & $\mathrm{EF}$ & $\mathrm{N}$ & B1 \\
\hline 5.2 .1 & 5 & dc1_us-brE & Bylaws & contrato socialMT & 5 & MT & S & $\mathrm{C} 1$ \\
\hline 5.2 .1 & 6 & co5_us-brJ & bylaws & Estatuto Social & 5 & $\mathrm{C}$ & $\mathrm{N}$ & D3 \\
\hline 5.2 .2 & 7 & dc4_uk-brE & Articles of Association & Estatutos Sociais & 5 & MT & $\mathrm{s}$ & $\mathrm{C} 1$ \\
\hline 5.2 .2 & 8 & pr4_ukn-brM & Articles of Association & contrato social & 5 & $\mathrm{C}$ & $\mathrm{s}$ & D2 \\
\hline 5.2 .2 & 9 & pr4_ukn-brM & $\begin{array}{l}\text { Amendment to the } \\
\text { Articles of Association }\end{array}$ & Alteração Contratual & 5 & C-M & $\mathrm{s}$ & D2 \\
\hline 5.2 .2 & 10 & pr4_ukn-brM & Articles of Association & $\begin{array}{l}\text { estatutos e contratos } \\
\text { sociais }\end{array}$ & 5 & C-EX & $\mathrm{s}$ & D2 \\
\hline 5.2 .2 & 11.1 & dc3_uk-brE & $\begin{array}{l}\text { Memorandum of } \\
\text { Association }\end{array}$ & $\begin{array}{l}\text { Instrumento de } \\
\text { Constituição }\end{array}$ & 3 & $\mathrm{EF}$ & $\mathrm{s}$ & $\mathrm{C} 1$ \\
\hline 5.2 .2 & 11.2 & dc3_uk-brE & Articles of Association & Estatutos Sociais & 5 & MT & $\mathrm{S}$ & $\mathrm{C} 1$ \\
\hline 5.2 .2 & 12.1 & dc2_uk-brB & $\begin{array}{l}\text { Memorandum of } \\
\text { Association }\end{array}$ & $\begin{array}{l}\text { Protocolo de } \\
\text { Constituição }\end{array}$ & 3 & $\mathrm{M}$ & $\mathrm{s}$ & $\mathrm{C} 1$ \\
\hline 5.2 .2 & 12.2 & dc2_uk-brB & Articles of Association & Contrato Social & 5 & MT & $\mathrm{s}$ & $\mathrm{C} 1$ \\
\hline 5.2 .2 & 13 & dc4_uk-brE & $\begin{array}{l}\text { Memorandum of } \\
\text { Association }\end{array}$ & $\begin{array}{l}\text { Instrumento de } \\
\text { Constituição }\end{array}$ & 3 & $\mathrm{EF}$ & $\mathrm{s}$ & C1 \\
\hline
\end{tabular}




\begin{tabular}{|c|c|c|c|c|c|c|c|c|}
\hline 5.2 .3 & 14 & co52_br-usK & contrato social & articles of association & 5 & MP & n & A2 \\
\hline 5.2 .3 & 15 & dc52_br-usD & contrato social & articles of association & 5 & MP & n & D3 \\
\hline 5.2 .3 & 16 & dc54_br-usnE & contrato social & articles of association & 5 & MP & $\mathrm{s}$ & A1 \\
\hline 5.2 .3 & 17 & dc52_br-usD & atos constitutivos & articles of association & 5 & MP & $n$ & D3 \\
\hline 5.2 .3 & 18 & dc51_br-usL & contrato social & articles of organization & 5 & MP & n & A1 \\
\hline 5.2 .3 & 19 & dc53_br-usnE & contrato social & operating agreement & 3 & EF & $n$ & A1 \\
\hline 5.2 .3 & 20 & co60_br-usP & atos constitutivos & articles of incorporation & 5 & MP & n & A1 \\
\hline 5.2 .3 & 21 & dc50_br-usL & estatuto social & by-laws & 5 & MP & $n$ & A1 \\
\hline 5.2 .3 & 22 & dc50_br-usL & regimento interno & association rules & 3 & EF & n & A1 \\
\hline 5.2 .3 & 23 & co61_br-usQ & estatutos sociais & corporate by-laws & 5 & MP & n & $\mathrm{C} 2$ \\
\hline 5.2 .3 & 24 & co51_br-usD & atos constitutivos & articles of incorporation & 5 & MP & n & $\mathrm{A} 1 / \mathrm{B} 1$ \\
\hline 5.2 .3 & 25 & pr52_br-usnM & estatuto social & $\begin{array}{l}\text { constituting and } \\
\text { operating document }\end{array}$ & 3 & EF & $\mathrm{s}$ & $\begin{array}{ll}\mathrm{C} 1 / \mathrm{D} 1 / \\
\mathrm{D} 2\end{array}$ \\
\hline 5.2 .3 & 26 & co50_br-usL & contrato social & charter & 3 & $M$ & $\mathrm{~N}$ & B1 \\
\hline 5.2 .3 & 27.1 & dc52_br-usD & contrato social & articles of association & 5 & MP & $n$ & D3 \\
\hline 5.2 .3 & 27.2 & dc52_br-usD & estatuto social & by-laws & 5 & MP & n & D3 \\
\hline 5.2 .3 & 28 & pr53_br-usnM & $\begin{array}{l}\text { contrato social } \\
\text { consolidado }\end{array}$ & $\begin{array}{l}\text { restated limited liability } \\
\text { company agreementM- } \\
\text { EX [contrato } \\
\text { social]EMP }\end{array}$ & 4 & $\begin{array}{l}\text { EMP- } \\
\text { EX-M }\end{array}$ & $\mathrm{s}$ & $\mathrm{C} 1$ \\
\hline 5.2 .3 & 29 & co55_br-usnH & constituição societária & corporate charter & 3 & $M$ & n & A1/ B1 \\
\hline 5.3 .1 & 30 & pr2_us-brM & $\begin{array}{l}\text { This is a Durable Power } \\
\text { of Attorney. }\end{array}$ & $\begin{array}{l}\text { Esta é uma Procuração } \\
\text { com poderes gerais e } \\
\text { subsistentes na } \\
\text { incapacidade do } \\
\text { OutorganteEF. }\end{array}$ & 4 & EF & $\mathrm{s}$ & $\mathrm{C} 1$ \\
\hline 5.3 .2 & 31 & dc4_us-brE & joint venture & $\begin{array}{l}\text { empreendimento } \\
\text { conjuntoD }\end{array}$ & 2 & $\mathrm{D}$ & $\mathrm{s}$ & $\mathrm{C} 1$ \\
\hline 5.3 .2 & 32 & dc2_uk-brB & joint venture & “joint venture"EMP & 3 & EMP & $\mathrm{s}$ & $\mathrm{C} 1$ \\
\hline 5.3 .2 & 33 & dc52_br-usD & $\begin{array}{l}\text { Contrato de Joint Venture } \\
\text { (Joint Venture } \\
\text { Agreement) }\end{array}$ & $\begin{array}{l}\text { Joint Venture } \\
\text { AgreementT-L-I }\end{array}$ & 5 & I-L-T & $\mathrm{n}$ & D3 \\
\hline 5.3 .2 & 34 & dc52_br-usD & Contrato de Joint Venture & $\begin{array}{l}\text { Joint Venture } \\
\text { AgreementT-L }\end{array}$ & 5 & L-T & $n$ & D3 \\
\hline
\end{tabular}




\begin{tabular}{|c|c|c|c|c|c|c|c|c|}
\hline 5.3 .3 & 35 & pr4_ukn-brM & $\begin{array}{l}\text { and to grant powers to } \\
\text { attorneys-at-laws in order } \\
\text { to }\end{array}$ & $\begin{array}{l}\text { outorgar mandatos a } \\
\text { advogadosEO para }\end{array}$ & 5 & EO & $\mathrm{s}$ & D2 \\
\hline 5.3 .3 & 36 & pr4_ukn-brM & $\begin{array}{l}\text { pursuant to the "ad judicia } \\
\text { et extra" clause }\end{array}$ & $\begin{array}{l}\text { nos termos da cláusula } \\
\text { "ad judicia et extra"L-T }\end{array}$ & 5 & L-T & $\mathrm{s}$ & D2 \\
\hline 5.3 .3 & 37 & pr51_br-usL & $\begin{array}{l}\text { cláusula ad judicia et } \\
\text { extra, }\end{array}$ & $\begin{array}{l}\text { legal representation } \\
\text { clauseEF }\end{array}$ & 3 & EF & n & $\mathrm{A} 1 / \mathrm{C} 2$ \\
\hline 5.3 .3 & 38 & dc53_br-usnE & procuradores & attorneys-at-lawME & 5 & $\mathrm{ME}$ & n & A1 \\
\hline 5.3 .3 & 39 & co61_br-usQ & procuradores & attorneysM & 3 & $M$ & $n$ & $\mathrm{C} 2$ \\
\hline 5.3 .4 & 40 & col_us-brnC & appellate court, & Tribunal de RecursosL, & 3 & $\mathrm{~L}$ & $\mathrm{~N}$ & B1 \\
\hline 5.3 .4 & 41 & col_us-brnC & $\begin{array}{l}\text { State1 Supreme Judicial } \\
\text { Court }\end{array}$ & $\begin{array}{l}\text { Supremo Tribunal } \\
\text { Judicial de State1L }\end{array}$ & 4 & $\mathrm{~L}$ & $\mathrm{~N}$ & B1 \\
\hline 5.3 .4 & 42 & col1_us-brN & $\begin{array}{l}\text { United States District } \\
\text { Court }\end{array}$ & $\begin{array}{l}\text { Corte Distrital dos } \\
\text { Estados Unidos da } \\
\text { AméricaD-L }\end{array}$ & 4 & D-L & $\mathrm{N}$ & B1 \\
\hline 5.3 .4 & 43 & co3_us-brG & $\begin{array}{l}\text { THE UNITED STATES } \\
\text { DISTRICT COURT }\end{array}$ & $\begin{array}{l}\text { EM JUÍZO } \\
\text { DISTRITALD } \\
\text { FEDERALEX DOS } \\
\text { ESTADOS UNIDOSL }\end{array}$ & 4 & D-EX-L & $\mathrm{N}$ & B1 \\
\hline 5.3 .4 & 44 & co2_us-brG & state or federal court & $\begin{array}{l}\text { juízo ou tribunalEX } \\
\text { federal ou estadualL }\end{array}$ & 3 & EX-L & $\mathrm{N}$ & B1 \\
\hline 5.3 .4 & 45 & co3_us-brG & $\begin{array}{l}\text { THE COURTS OF THE } \\
\text { State } 1\end{array}$ & O FOROL DO & 3 & $\mathrm{~L}$ & $\mathrm{~N}$ & B1 \\
\hline 5.3 .4 & 46 & co5_us-brJ & the Courts & o foroL & 3 & $\mathrm{~L}$ & $\mathrm{~N}$ & D3 \\
\hline 5.3 .4 & 47 & pr8_ukn-brH & $\begin{array}{l}\text { any Brazilian civil, } \\
\text { criminal or administrative } \\
\text { court, }\end{array}$ & qualquer tribunalI & 3 & I & $\mathrm{n}$ & D3 \\
\hline 5.3 .4 & 48.1 & pr4_ukn-brM & before the courts & no foro em geralM, & 3 & $\mathrm{M}$ & $\mathrm{s}$ & $\mathrm{D} 2$ \\
\hline 5.3 .4 & 48.2 & pr4_ukn-brM & in whatever instance & em qualquer instânciaC, & 5 & $\mathrm{C}$ & $\mathrm{s}$ & D2 \\
\hline 5.3 .4 & 49 & pr6_ukn-br & Commercial Courts & Tribunais ComerciaisL & 3 & $\mathrm{~L}$ & $\mathrm{~s}$ & D2 \\
\hline 5.3 .4 & 50 & co56_br-usD & foro & courtL & 3 & $\mathrm{~L}$ & n & $\mathrm{A} 1 / \mathrm{B} 1$ \\
\hline 5.3 .4 & 51 & co57_br-usD & foro & courtL & 3 & $\mathrm{~L}$ & $\mathrm{n}$ & $\mathrm{A} 1 / \mathrm{B} 1$ \\
\hline 5.3 .4 & 52 & co58_br-usD & foro & courtL & 3 & $\mathrm{~L}$ & n & A1/ B1 \\
\hline
\end{tabular}




\begin{tabular}{|c|c|c|c|c|c|c|c|c|}
\hline 5.3 .4 & 53 & pr54_br-usnM & $\begin{array}{l}2^{\mathrm{a}} \text { Vara da Família e } \\
\text { Sucessões }\end{array}$ & $\begin{array}{l}\text { Second Court of Family } \\
\text { and SuccessionL }\end{array}$ & 3 & $\mathrm{~L}$ & $\mathrm{~s}$ & C1 \\
\hline 5.3 .4 & 54 & co52_br-usK & foro & courtsL & 3 & $\mathrm{~L}$ & $n$ & A2 \\
\hline 5.3 .4 & 55 & dc53_br-usnE & foro Central & courtL-O & 3 & $\mathrm{~L}-\mathrm{O}$ & $n$ & A1 \\
\hline 5.3 .4 & 56 & co61_br-usQ & Foro Central & Central CourtL & 3 & $\mathrm{~L}$ & $n$ & $\mathrm{C} 2$ \\
\hline 5.3 .4 & 57.1 & co50_br-usL & foro & courtL & 3 & $\mathrm{~L}$ & $\mathrm{~N}$ & B1 \\
\hline 5.3 .4 & 57.2 & co50_br-usL & situação do Imóvel & $\begin{array}{l}\text { district where the } \\
\text { property is locatedEF }\end{array}$ & 3 & EF & $\mathrm{N}$ & B1 \\
\hline 5.3 .4 & 58 & co51_br-usD & foro & court jurisdictionM & 3 & $\mathrm{M}$ & $n$ & A1/B1 \\
\hline 5.3 .4 & 59 & co60_br-usP & o foro & the forumL & 3 & $\mathrm{~L}$ & $n$ & A1 \\
\hline 5.3 .4 & 60.1 & co50_br-usL & Foro Central & Central CourtL & 3 & $\mathrm{~L}$ & $\mathrm{~N}$ & B1 \\
\hline 5.3 .4 & 60.2 & co50_br-usL & Comarca & DistrictEO & 5 & EO & $\mathrm{N}$ & B1 \\
\hline 5.3 .4 & 61.1 & co53_br-usnF & Foro Central & Central CourtsL & 3 & $\mathrm{~L}$ & $\mathrm{~s}$ & D2 \\
\hline 5.3 .4 & 61.2 & co53_br-usnF & Comarca & CountyEC & 5 & EC & $\mathrm{s}$ & D2 \\
\hline 5.3 .4 & 62.1 & co59_br-usL & foro & venueM & 3 & $\mathrm{M}$ & $n$ & B1 \\
\hline 5.3 .4 & 62.2 & co59_br-usL & Comarca & judicial districtEO & 5 & EO & $n$ & B1 \\
\hline 5.3 .4 & 63.1 & dc52_br-usD & foro jurídico & court jurisdictionM & 3 & $\mathrm{M}$ & $n$ & D3 \\
\hline 5.3 .4 & 63.2 & dc52_br-usD & Comarca & Judicial DistrictEO & 5 & EO & $n$ & D3 \\
\hline 5.3 .4 & 64.1 & co55_br-usnH & foro & courtL-I & 3 & $\mathrm{I}-\mathrm{L}$ & $\mathrm{n}$ & $\mathrm{A} 1 / \mathrm{B} 1$ \\
\hline 5.3 .4 & 64.2 & co55_br-usnH & Comarca & <omissão $>$ & 3 & $\mathrm{O}$ & $n$ & A1/ B1 \\
\hline 5.3 .4 & 65.1 & dc54_br-usnE & foro da & the courtL of the & 3 & $\mathrm{~L}$ & $\mathrm{~s}$ & A1 \\
\hline 5.3 .4 & 65.2 & dc54_br-usnE & Comarca & administrative regionEF & 3 & EF & $\mathrm{s}$ & A1 \\
\hline 5.3 .5 & 66 & co59_br-usL & FORO & VENUE & 3 & M & n & B1 \\
\hline 5.3 .5 & 67 & co52_br-usK & DO FORO & VENUE & 3 & M & $\mathrm{n}$ & A2 \\
\hline 5.3 .5 & 68 & co53_br-usnF & ELEIÇÃO DE FORO & VENUE & 3 & $\mathrm{M}$ & $\mathrm{s}$ & $\mathrm{D} 2$ \\
\hline 5.3 .5 & 69 & co55_br-usnH & DO FORO & VENUE & 3 & M & $n$ & A1/ B1 \\
\hline 5.3 .5 & 70 & co61_br-usQ & FORO & LEGAL VENUE & 3 & M & n & $\mathrm{C} 2$ \\
\hline 5.3 .5 & 71 & co51_br-usD & FORO & JURISDICTION & 3 & $\mathrm{M}$ & $n$ & $\mathrm{~A} 1 / \mathrm{B} 1$ \\
\hline 5.3 .5 & 72 & co57_br-usD & FORO & JURISDICTION & 3 & $\mathrm{M}$ & $\mathrm{n}$ & $\mathrm{A} 1 / \mathrm{B} 1$ \\
\hline 5.3 .5 & 73 & co58_br-usD & DO FORO & JURISDICTION & 3 & $\mathrm{M}$ & $n$ & A1/ B1 \\
\hline 5.3 .5 & 74 & dc53_br-usnE & DO FORO & COURT & 3 & $\mathrm{~L}$ & n & A1 \\
\hline 5.3 .5 & 75 & co60_br-usP & ELEIÇÃO DE FORO & $\begin{array}{l}\text { SELECTION OF } \\
\text { FORUM }\end{array}$ & 2 & $\mathrm{M}$ & $\mathrm{n}$ & A1 \\
\hline
\end{tabular}




\begin{tabular}{|c|c|c|c|c|c|c|c|c|}
\hline 5.3 .5 & 76 & dc52_br-usD & $\begin{array}{l}\text { DENOMINAÇÃO, } \\
\text { SEDE E FORO }\end{array}$ & $\begin{array}{l}\text { COMPANY NAME, } \\
\text { PRINCIPAL PLACE } \\
\text { OF BUSINESS AND } \\
\text { GOVERNING LAW }\end{array}$ & 5 & EDV & $\mathrm{n}$ & D3 \\
\hline 5.3 .5 & 77 & dc52_br-usD & Leis Aplicáveis & Governing Law & 5 & EDV & n & D3 \\
\hline 5.3 .5 & 78 & co7_usn-brF & $\begin{array}{l}\text { Governing Law and } \\
\text { Disputes }\end{array}$ & $\begin{array}{l}\text { Legislação RegenteL e } \\
\text { Contendas }\end{array}$ & 2 & $\mathrm{~L}$ & n & A2 \\
\hline 5.3 .5 & 79 & co6_us-brA & Governing Law & Lei AplicávelM & 3 & $\mathrm{M}$ & n & $\mathrm{B} 1$ \\
\hline 5.3 .5 & 80 & co5_us-brJ & Jurisdiction & Foro de eleiçãoEDV & 5 & EDV & $\mathrm{N}$ & D3 \\
\hline 5.3 .6 & 81 & co6_us-brA & $\begin{array}{l}\text { court of competent } \\
\text { jurisdiction }\end{array}$ & $\begin{array}{l}\text { foro da jurisdição } \\
\text { competenteL }\end{array}$ & 3 & $\mathrm{~L}$ & n & $\mathrm{B} 1$ \\
\hline 5.3 .6 & 81 & dc4_uk-brE & $\begin{array}{l}\text { court of competent } \\
\text { jurisdiction }\end{array}$ & $\begin{array}{l}\text { foro da jurisdição } \\
\text { competenteL }\end{array}$ & 3 & $\mathrm{~L}$ & $\mathrm{~s}$ & C1 \\
\hline 5.3 .6 & 82 & dc2_uk-brB & $\begin{array}{l}\text { court of competent } \\
\text { jurisdiction }\end{array}$ & $\begin{array}{l}\text { tribunal com jurisdição } \\
\text { competenteL }\end{array}$ & 3 & $\mathrm{~L}$ & $\mathrm{~s}$ & $\mathrm{C} 1$ \\
\hline 5.3 .6 & 83 & co8_us-brF & $\begin{array}{l}\text { court of competent } \\
\text { jurisdiction }\end{array}$ & $\begin{array}{l}\text { tribunal de jurisdição } \\
\text { competenteL }\end{array}$ & 3 & $\mathrm{~L}$ & $\mathrm{n}$ & A2 \\
\hline 5.3 .6 & 84 & co6_us-brA & $\begin{array}{l}\text { court of competent } \\
\text { jurisdiction }\end{array}$ & $\begin{array}{l}\text { tribunal da jurisdição } \\
\text { competenteL }\end{array}$ & 3 & $\mathrm{~L}$ & n & $\mathrm{B} 1$ \\
\hline 5.3 .6 & 85 & co2_us-brG & $\begin{array}{l}\text { court of competent } \\
\text { jurisdiction }\end{array}$ & $\begin{array}{l}\text { juízo ou tribunalEX } \\
\text { competenteI }\end{array}$ & 3 & EX-I & $\mathrm{N}$ & $\mathrm{B} 1$ \\
\hline 5.3 .7 & 86 & co59_br-usL & 21. FORÇA MAIOR & 21. ACTS OF GODEO & 5 & EO & n & $\mathrm{B} 1$ \\
\hline 5.3 .7 & 87 & co59_br-usL & $\begin{array}{l}\text { casos fortuitos ou de força } \\
\text { maior. }\end{array}$ & acts of God.MP & 5 & MP & $\mathrm{n}$ & B1 \\
\hline 5.3 .7 & 88 & co55_br-usnH & força maior & force majeureMT & 5 & MT & n & A1/ B1 \\
\hline 5.3 .7 & 89 & co4_us-brJ & force majeur & força maiorMP & 5 & MP & $\mathrm{N}$ & A1/ B1 \\
\hline 5.3 .7 & 89 & co6_us-brA & force majeur & força maiorMP & 5 & MP & n & $\mathrm{B} 1$ \\
\hline 5.3 .8 & 90 & co2_us-brG & in good faith & de boa féL & 5 & $\mathrm{~L}$ & $\mathrm{~N}$ & $\mathrm{~B} 1$ \\
\hline 5.3 .8 & 90 & co3_us-brG & in good faith & de boa féL & 5 & $\mathrm{~L}$ & $\mathrm{~N}$ & $\mathrm{~B} 1$ \\
\hline 5.3 .8 & 90 & co4_us-brJ & in good faith & de boa féL & 5 & $\mathrm{~L}$ & $\mathrm{~N}$ & A1/ B1 \\
\hline 5.3 .8 & 90 & co7_usn-brF & in good faith & de boa féL & 5 & $\mathrm{~L}$ & $\mathrm{n}$ & A2 \\
\hline 5.3 .8 & 90 & dc4_uk-brE & in good faith & de boa féL & 5 & $\mathrm{~L}$ & $\mathrm{~s}$ & $\mathrm{C} 1$ \\
\hline 5.3 .8 & 91 & co3_us-brG & in good faith & em boa féL & 5 & $\mathrm{~L}$ & $\mathrm{~N}$ & $\mathrm{~B} 1$ \\
\hline 5.3 .8 & 91 & dc2_uk-brB & in good faith & em boa féL & 5 & $\mathrm{~L}$ & $\mathrm{~s}$ & $\mathrm{C} 1$ \\
\hline
\end{tabular}




\begin{tabular}{|c|c|c|c|c|c|c|c|c|}
\hline 5.3 .8 & 91 & pr2_us-brM & in good faith & em boa féL & 5 & $\mathrm{~L}$ & S & $\mathrm{C} 1$ \\
\hline 5.3 .8 & 92 & dc2_uk-brB & are disclosed good faith & revelados de boa féL & 5 & $\mathrm{~L}$ & $\mathrm{~s}$ & $\mathrm{C} 1$ \\
\hline 5.3 .8 & 93 & dc2_uk-brB & good faith & boa féM & 5 & $M$ & $\mathrm{~s}$ & $\mathrm{C} 1$ \\
\hline 5.3 .8 & 94 & pr2_us-brM & $\begin{array}{l}\text { or the failure to act in } \\
\text { good faith }\end{array}$ & má féM & 5 & $\mathrm{M}$ & $\mathrm{s}$ & $\mathrm{C} 1$ \\
\hline 5.3 .8 & 95 & dc1_us-brE & not in good faith & de má féM & 5 & $M$ & $\mathrm{~s}$ & $\mathrm{C} 1$ \\
\hline 5.3 .8 & 96 & co3_us-brG & in the good faith judgment & $\begin{array}{l}\text { no parecer em boa féL } \\
\text { do Banco }\end{array}$ & 5 & $\mathrm{M}$ & $\mathrm{N}$ & B1 \\
\hline 5.3 .8 & 97 & co6_us-brA & $\begin{array}{l}\text { the good faith pursuit of } \\
\text { the foregoing. }\end{array}$ & a boa-féL de & 5 & $\mathrm{~L}$ & n & B1 \\
\hline 5.3 .8 & 98 & dc52_br-usD & de boa fé & in good faithL & 5 & $\mathrm{~L}$ & n & D3 \\
\hline 5.3 .8 & 99 & dc52_br-usD & de boa fé, & in good faithL & 5 & $\mathrm{~L}$ & n & D3 \\
\hline 5.3 .9 & 100 & col1_us-brN & best efforts to & maiores esforçosD & 2 & $\mathrm{D}$ & $\mathrm{N}$ & B1 \\
\hline 5.3 .9 & 101 & co4_us-brJ & best efforts to & melhores esforçosD & 2 & $\mathrm{D}$ & $\mathrm{N}$ & $\mathrm{A} 1 / \mathrm{B} 1$ \\
\hline 5.3 .9 & 102 & co51_br-usD & melhores esforços & <omissão $>$ & 3 & $\mathrm{O}$ & n & $\mathrm{A} 1 / \mathrm{B} 1$ \\
\hline 5.3 .9 & 103 & dc52_br-usD & seus melhores esforços, & $<$ omissão $>$ & 3 & $\mathrm{O}$ & n & D3 \\
\hline 5.3 .9 & 104 & co52_br-usK & Aplicar todo zelo, & $\begin{array}{l}\text { Put forth its best } \\
\text { effortsEO, }\end{array}$ & 5 & $\mathrm{EO}$ & n & A2 \\
\hline 5.3 .10 & 105 & dc4_uk-brE & $\begin{array}{l}\text { the entering of a nolle } \\
\text { prosequi }\end{array}$ & $\begin{array}{l}\text { arquivamento do } \\
\text { processoEF }\end{array}$ & 3 & $\mathrm{EF}$ & $\mathrm{s}$ & $\mathrm{C} 1$ \\
\hline 5.3 .10 & 106 & dc3_uk-brE & $\begin{array}{l}\text { the issue of shares pari } \\
\text { passu }\end{array}$ & $\begin{array}{l}\text { emissão de ações pari } \\
\text { passuT-ER }\end{array}$ & 1 & ER-T & $\mathrm{s}$ & $\mathrm{C} 1$ \\
\hline 5.3 .10 & 107 & dc3_uk-brE & pari passu therewith. & $\begin{array}{l}\text { pari passuT-ER com } \\
\text { aquelas }\end{array}$ & 1 & ER-T & $\mathrm{s}$ & $\mathrm{C} 1$ \\
\hline 5.3 .11 & 108 & pr54_br-usnM & $\begin{array}{l}\text { pelo regime da comunhão } \\
\text { parcial de bens }\end{array}$ & $\begin{array}{l}\text { under the community } \\
\text { property systemEO }\end{array}$ & 5 & EO & $\mathrm{s}$ & $\mathrm{C} 1$ \\
\hline 5.3 .11 & 109 & co50_br-usL & $\begin{array}{l}\text { pelo regime da comunhão } \\
\text { universal de bens }\end{array}$ & $\begin{array}{l}\text { under the full } \\
\text { community property } \\
\text { regimeM-L }\end{array}$ & 3 & L-M & $\mathrm{N}$ & B1 \\
\hline 5.4 .1 & 110 & dc51_br-usL & quotista & quotaholderD & 2 & $\mathrm{D}$ & n & A1 \\
\hline 5.4 .1 & 111 & co50_br-usL & quotistas & quota holdersD & 2 & $\mathrm{D}$ & $\mathrm{N}$ & B1 \\
\hline 5.4 .1 & 112 & dc52_br-usD & sócio & quotaholderD & 2 & $\mathrm{D}$ & n & D3 \\
\hline 5.4 .1 & 113 & dc54_br-usnE & quotista & quotaholderD & 2 & $\mathrm{D}$ & $\mathrm{s}$ & A1 \\
\hline
\end{tabular}




\begin{tabular}{|c|c|c|c|c|c|c|c|c|}
\hline 5.4 .1 & 114 & dc53_br-usnE & quotista & memberEO & 5 & EO & n & A1 \\
\hline 5.4 .1 & 115 & pr53_br-usnM & quotista gerente & $\begin{array}{l}\text { managing memberEO } \\
\text { [quotista gerente]EMP }\end{array}$ & 4 & $\begin{array}{l}\text { EMP- } \\
\text { EO }\end{array}$ & $\mathrm{s}$ & $\mathrm{C} 1$ \\
\hline 5.4 .1 & 116 & dc51_br-usL & quota & quotaEMP & 1 & EMP & $n$ & A1 \\
\hline 5.4 .1 & 116 & dc52_br-usD & quota & quotaEMP & 1 & EMP & n & D3 \\
\hline 5.4 .1 & 116 & dc54_br-usnE & quota & quotaEMP & 1 & EMP & $\mathrm{s}$ & A1 \\
\hline 5.4 .1 & 117 & co50_br-usL & quotas ou ações & quotasEMP or shares & 1 & EMP & $\mathrm{N}$ & B1 \\
\hline 5.4 .1 & 118 & dc53_br-usnE & quotas & sharesM & 3 & M & n & A1 \\
\hline 5.4 .1 & 119 & pr8_ukn-brH & quota & quotaT & 5 & $\mathrm{~T}$ & n & D3 \\
\hline 5.4 .1 & 119 & pr4_ukn_brM & quota & quotaT & 5 & $\mathrm{~T}$ & $\mathrm{~s}$ & D2 \\
\hline 5.4 .1 & 120 & pr8_ukn-brH & as a quotaholder & $\begin{array}{l}\text { na qualidade de sócia- } \\
\text { quotistaT }\end{array}$ & 5 & $\mathrm{C}$ & $n$ & D3 \\
\hline 5.4 .1 & 121 & dc2_uk-brB & member & SócioEO & 5 & EO & $\mathrm{s}$ & $\mathrm{C} 1$ \\
\hline 5.4 .1 & 121 & dc4_uk-brE & member & SócioEO & 5 & $\mathrm{EO}$ & $\mathrm{s}$ & $\mathrm{C} 1$ \\
\hline 5.4 .2 & 122 & pr50_br-usL & retirar talões de cheques, & pick upEF checkbooks, & 3 & EF & n & $\mathrm{A} 1 / \mathrm{C} 2$ \\
\hline 5.4 .2 & 123 & co61-br-usQ & ficha de compensação & bank collection slipsEF & 3 & $\mathrm{EF}$ & n & $\mathrm{C} 2$ \\
\hline 5.4 .3 & 124.1 & co50_br-usL & $\begin{array}{l}\text { IGM-M - Índice Geral de } \\
\text { Preços do Mercado }\end{array}$ & $\begin{array}{l}\text { IGP-MEMP (General } \\
\text { Market Price IndexL - } \\
\text { Índice Geral de Preços } \\
\text { do MercadoEMP) }\end{array}$ & 4 & EMP-L & $\mathrm{N}$ & $\mathrm{B} 1$ \\
\hline 5.4 .3 & 124.2 & co50_br-usL & $\begin{array}{l}\text { divulgado pela Fundação } \\
\text { Getúlio Vargas (FGV). }\end{array}$ & $\begin{array}{l}\text { released by the Getúlio } \\
\text { VargasT FoundationL } \\
\text { (FGV)EMP. }\end{array}$ & 4 & $\begin{array}{l}\text { EMP-L- } \\
\mathrm{T}\end{array}$ & $\mathrm{N}$ & B1 \\
\hline 5.4 .3 & 125.1 & co50_br-usL & Índice Geral de Preços, & $\begin{array}{l}\text { The IGP/FGVEMP } \\
\text { (General Price IndexL - } \\
\text { Índice Geral de } \\
\text { PreçosEMP), }\end{array}$ & 4 & EMP-L & $\mathrm{N}$ & B1 \\
\hline 5.4 .3 & 125.2 & co50_br-usL & $\begin{array}{l}\text { publicado pela Fundação } \\
\text { Getúlio Vargas } \\
\text { (IGP/FGV) }\end{array}$ & $\begin{array}{l}\text { published by the } \\
\text { Getúlio VargasT } \\
\text { FoundationL }\end{array}$ & 4 & L-T & $\mathrm{N}$ & B1 \\
\hline
\end{tabular}




\begin{tabular}{|c|c|c|c|c|c|c|c|c|}
\hline 5.4 .3 & 126.1 & co50_br-usL & $\begin{array}{l}\text { Índice de Preços ao } \\
\text { Consumidor, }\end{array}$ & $\begin{array}{l}\text { the IPC/FIPEEMP } \\
\text { (Consumer Price } \\
\text { IndexL - Índice de } \\
\text { Preços ao } \\
\text { ConsumidorEMP), }\end{array}$ & 4 & EMP-L & $\mathrm{N}$ & B1 \\
\hline 5.4 .3 & 126.2 & co50_br-usL & $\begin{array}{l}\text { publicado pela Fundação } \\
\text { Instituto de Pesquisas da } \\
\text { Universidade de São } \\
\text { Paulo (IPC/FIPE). }\end{array}$ & $\begin{array}{l}\text { published by the } \\
\text { EconomicEX Research } \\
\text { Institute FoundationL of } \\
\text { the University of São } \\
\text { PauloL. }\end{array}$ & 4 & EX-L & $\mathrm{N}$ & B1 \\
\hline 5.4 .3 & 127.1 & co51_br-usD & $\begin{array}{l}\text { IGP-M/FGV (Índice Geral } \\
\text { de Preços - Mercado, }\end{array}$ & $\begin{array}{l}\text { General Market Price } \\
\text { IndexL (IGP- } \\
\text { M/FGV)EMP }\end{array}$ & 3 & EMP-L & $n$ & $\mathrm{~A} 1 / \mathrm{B} 1$ \\
\hline 5.4 .3 & 127.2 & co51_br-usD & $\begin{array}{l}\text { publicado pela Fundação } \\
\text { Getúlio Vargas) }\end{array}$ & $\begin{array}{l}\text { published by the } \\
\text { Getúlio VargasT } \\
\text { FoundationL }\end{array}$ & 4 & L-T & n & A1/ B1 \\
\hline 5.4 .3 & 128.1 & co51_br-usD & $\begin{array}{l}\text { IGP-DI - Índice Geral de } \\
\text { Preços - Disponibilidade } \\
\text { Interna, }\end{array}$ & $\begin{array}{l}\text { IGP-DIEMP: the } \\
\text { General Price Index - } \\
\text { Domestic AvailabilityL, }\end{array}$ & 3 & EMP-L & n & $\mathrm{A} 1 / \mathrm{B} 1$ \\
\hline 5.4 .3 & 128.2 & co51_br-usD & publicado pela FGV & published by FGVEMP & 1 & EMP & n & A1/ B1 \\
\hline 5.4 .3 & 129.1 & co51_br-usD & $\begin{array}{l}\text { IPCA - Índice de Preços } \\
\text { ao Consumidor Amplo, }\end{array}$ & $\begin{array}{l}\text { IPCAEMP: the Broad- } \\
\text { basedM Consumer } \\
\text { Price IndexL, }\end{array}$ & 3 & $\begin{array}{l}\text { EMP-L- } \\
\mathrm{M}\end{array}$ & n & $\mathrm{A} 1 / \mathrm{B} 1$ \\
\hline 5.4 .3 & 129.2 & co51_br-usD & publicado pelo IBGE; & $\begin{array}{l}\text { published by } \\
\text { IBGEEMP; }\end{array}$ & 1 & EMP & n & A1/ B1 \\
\hline 5.4 .3 & 130.1 & co51_br-usD & $\begin{array}{l}\text { IPC - Índice de Preços ao } \\
\text { Consumidor, publicado } \\
\text { pela }\end{array}$ & $\begin{array}{l}\text { IPCEMP: the Consumer } \\
\text { Price IndexL published } \\
\text { by the }\end{array}$ & 3 & EMP-L & n & A1/ B1 \\
\hline 5.4 .3 & 130.2 & co51_br-usD & FIPE. & $\begin{array}{l}\text { Institute of Economic } \\
\text { Research FoundationL- } \\
\text { EX of the University of } \\
\text { São PauloEX } \\
\text { (FIPE)EMP }\end{array}$ & 4 & $\begin{array}{l}\text { EMP- } \\
\text { EX-L }\end{array}$ & n & $\mathrm{A} 1 / \mathrm{B} 1$ \\
\hline 5.4 .3 & 131.1 & co61_br-usQ & I.G.P.M./ & $\begin{array}{l}\text { General Market Price } \\
\text { IndexL-EX (IGP- }\end{array}$ & 3 & $\begin{array}{l}\text { EMP- } \\
\text { EX-L }\end{array}$ & $\mathrm{n}$ & $\mathrm{C} 2$ \\
\hline
\end{tabular}




\begin{tabular}{|c|c|c|c|c|c|c|c|c|}
\hline & & & & MEMP) & & & & \\
\hline 5.4 .3 & 131.2 & co61_br-usQ & F.G.V & $\begin{array}{l}\text { published by the } \\
\text { Getulio VargasT } \\
\text { FoundationL-EX }\end{array}$ & 4 & EX-L-T & $\mathrm{n}$ & $\mathrm{C} 2$ \\
\hline 5.4 .3 & 132 & co60_br-usP & $\begin{array}{l}\text { ÍNDICE GERAL DE } \\
\text { PREÇOS DE MERCADO } \\
\text { (IGPM) }\end{array}$ & $\begin{array}{l}\text { GENERAL INDEX OF } \\
\text { MARKET PRICESL } \\
\text { (IGPM, ÍNDICE } \\
\text { GERAL DE PREÇOS } \\
\text { DE MERCADO)EMP }\end{array}$ & 4 & EMP-L & $\mathrm{n}$ & A1 \\
\hline 5.4 .4 & 144 & co54_br-usnF & $\begin{array}{l}\text { com o sistema de } \\
\text { compensação de "dias- } \\
\text { ponte", }\end{array}$ & $\begin{array}{l}\text { with the "bridge-day"D } \\
\text { set-off system, with } \\
\text { respect to periodEX }\end{array}$ & 2 & D-EX & $\mathrm{N}$ & A1 \\
\hline 5.4 .5 & 145 & co51_br-usD & $\begin{array}{l}\text { O Imposto Predial } \\
\text { Territorial Urbano (IPTU) } \\
\text { será pago }\end{array}$ & $\begin{array}{l}\text { The MunicipalEX } \\
\text { Urban LandL and } \\
\text { PropertyM Tax } \\
\text { (IPTU)EMP shall be } \\
\text { paid }\end{array}$ & 4 & $\begin{array}{l}\text { EMP- } \\
\text { EX-L- } \\
\text { M }\end{array}$ & $n$ & A1/ B1 \\
\hline 5.4 .5 & 146 & co50_br-usL & IPTU & $\begin{array}{l}\text { IPTUEMP (Urban Land } \\
\text { and Building TaxesL - } \\
\text { Impostos Predial e } \\
\text { Territorial UrbanoEX }\end{array}$ & 4 & $\begin{array}{l}\text { EMP- } \\
\text { EX-L }\end{array}$ & $\mathrm{N}$ & B1 \\
\hline 5.4 .5 & 147 & co59_br-usL & $\begin{array}{l}\text { Imposto sobre Serviços de } \\
\text { qualquer natureza }\end{array}$ & $\begin{array}{l}\text { Service TaxM (ISSEX - } \\
\text { Imposto sobre Serviços } \\
\text { de Qualquer } \\
\text { Natureza)EMP }\end{array}$ & 4 & $\begin{array}{l}\text { EMP- } \\
\text { EX-M }\end{array}$ & $\mathrm{n}$ & B1 \\
\hline 5.5 .1 & 148 & pr50_br-usL & RG 0 & $\begin{array}{l}\text { with Brazilian } \\
\text { Identification } \\
\text { NumberEX-EF } \\
\text { (RG)EMP } 0\end{array}$ & 4 & $\begin{array}{l}\text { EF- } \\
\text { EMP- } \\
\text { EX }\end{array}$ & $\mathrm{n}$ & $\mathrm{A} 1 / \mathrm{C} 2$ \\
\hline 5.5 .1 & 149 & pr51_br-usL & $\begin{array}{l}\text { portador da Cédula de } \\
\text { Identidade } \mathrm{RG} \mathrm{n} \mathrm{n}^{\circ} 0\end{array}$ & $\begin{array}{l}\text { with Brazilian } \\
\text { IdentificationEX-EF-I } \\
\text { Number } 0\end{array}$ & 4 & $\begin{array}{l}\text { EF-EX- } \\
\text { I }\end{array}$ & $\mathrm{n}$ & A1/ C2 \\
\hline
\end{tabular}




\begin{tabular}{|c|c|c|c|c|c|c|c|c|}
\hline 5.5 .1 & 150 & dc51_br-usL & $\begin{array}{l}\text { portador do } \mathrm{CPF} \mathrm{n}^{\circ} 0 \mathrm{e} \\
\mathrm{RG} \mathrm{n}^{\circ} 0, \mathrm{SSP} / \mathrm{SP}\end{array}$ & $\begin{array}{l}\text { with ... and Brazilian } \\
\text { Identity CardEX-EF } \\
\text { Number } 0 \text { issued by the } \\
\text { São Paulo Secretary of } \\
\text { Public Safety }\end{array}$ & 4 & EF-EX & $\mathrm{n}$ & A1 \\
\hline 5.5 .1 & 151 & dc51_br-usL & $\begin{array}{l}\text { portador da cédula de } \\
\text { identidade RG n. } 0 \\
\text { SSP/SP, }\end{array}$ & $\begin{array}{l}\text { with ... and Brazilian } \\
\text { Identity CardEX-L } \\
\text { Number } 0 \text { issued by the } \\
\text { São Paulo Secretary of } \\
\text { Public Safety }\end{array}$ & 4 & EX-L & $\mathrm{n}$ & A1 \\
\hline 5.5 .1 & 152 & co50_br-usL & $\begin{array}{l}\text { portador da Cédula de } \\
\text { Identidade R.G. } \text { n }^{\circ} 0 \text { - } \\
\text { XX/XX }\end{array}$ & $\begin{array}{l}\text { bearer of Brazilian } \\
\text { Identity CardEX-L } \\
\text { (RG)EMP No. 0- } \\
\text { XX/XX }\end{array}$ & 4 & $\begin{array}{l}\text { EMP- } \\
\text { EX-L }\end{array}$ & $\mathrm{N}$ & B1 \\
\hline 5.5 .1 & 153 & co55_br-usnH & $\begin{array}{l}\text { portador da Cédula de } \\
\text { Identidade } \mathrm{RG} \mathrm{n} \mathrm{n}^{\circ} 0 \text { - } \\
\text { SSP/SP }\end{array}$ & $\begin{array}{l}\text { bearer of the Brazilian } \\
\text { Identity CardEX-L } \\
\text { (RG)EMP No. } 0 \text { - } \\
\text { SSP/SP }\end{array}$ & 4 & $\begin{array}{l}\text { EMP- } \\
\text { EX-L }\end{array}$ & $\mathrm{n}$ & A1/ B1 \\
\hline 5.5 .1 & 154 & co55_br-usnH & $\begin{array}{l}\text { portador da cédula de } \\
\text { identidade } R G \mathrm{n}^{\circ} 00000\end{array}$ & $\begin{array}{l}\text { bearer of the Brazilian } \\
\text { Identity CardEX-L } \\
\text { (RG)EMP No. } 00000\end{array}$ & 4 & $\begin{array}{l}\text { EMP- } \\
\text { EX-L }\end{array}$ & n & A1/B1 \\
\hline 5.5 .1 & 155 & pr52_br-usnM & $\begin{array}{l}\text { portador da cédula de } \\
\text { identidade RG no. } 0 \\
\text { SSP/SP }\end{array}$ & $\begin{array}{l}\text { holder of the identity } \\
\text { cardL No.ER RGEMP } \\
\text { no. } 0 \mathrm{SSP} / \mathrm{SP}\end{array}$ & 4 & $\begin{array}{l}\text { EMP- } \\
\text { ER-L }\end{array}$ & $\mathrm{s}$ & $\begin{array}{ll}\mathrm{C} 1 / & \mathrm{D} 1 / \\
\mathrm{D} 2\end{array}$ \\
\hline 5.5 .1 & 156 & pr53_br-usnM & $\begin{array}{l}\text { portador da cédula de } \\
\text { identidade RG no. 0/SSP- } \\
\text { SP }\end{array}$ & $\begin{array}{l}\text { holder of the identity } \\
\text { cardL 0/SSP-SP }\end{array}$ & 3 & $\mathrm{~L}$ & $\mathrm{~s}$ & $\mathrm{C} 1$ \\
\hline 5.5 .1 & 157 & pr53_br-usnM & $\begin{array}{l}\text { portador da cédula de } \\
\text { identidade RG no. 0/SSP- } \\
\text { SP }\end{array}$ & $\begin{array}{l}\text { holder of the identity } \\
\text { cardL No. RGEMP } 0\end{array}$ & 4 & EMP-L & $\mathrm{s}$ & C1 \\
\hline 5.5 .1 & 158 & dc53_br-usnE & $\begin{array}{l}\text { portador da Cédula de } \\
\text { Identidade RG n } 0, \\
\text { expedida pela SSP/SP }\end{array}$ & $\begin{array}{l}\text { bearer of Identity CardL } \\
\text { RGEMP No. 0, issued } \\
\text { by the Public Security } \\
\text { Department of the State } \\
\text { of São Paulo SSP/SP }\end{array}$ & 4 & EMP-L & n & A1 \\
\hline
\end{tabular}




\begin{tabular}{|c|c|c|c|c|c|c|c|c|}
\hline 5.5 .1 & 159 & pr54_br-usnM & $\begin{array}{l}\text { portador da cédula de } \\
\text { identidade de } R G n^{\circ} 0 \text { - } \\
\text { SSP/SP }\end{array}$ & $\begin{array}{l}\text { holder of Identity } \\
\text { CardL RGEMP No. 0- } \\
\text { SSP/SP }\end{array}$ & 4 & EMP-L & $\mathrm{s}$ & $\mathrm{Cl}$ \\
\hline 5.5 .1 & 160 & co54_br-usnF & $\begin{array}{l}\text { portador da Cédula de } \\
\text { Identidade RG } 0\end{array}$ & $\begin{array}{l}\text { bearer of Identity CardL } \\
\text { no. RGEMP } 0\end{array}$ & 4 & EMP-L & $\mathrm{N}$ & A1 \\
\hline 5.5 .1 & 161 & co56_br-usD & RG.: & $\begin{array}{l}\text { RGEMP IdentityEF } \\
\text { No.: }\end{array}$ & 4 & $\begin{array}{l}\text { EF- } \\
\text { EMP }\end{array}$ & $\mathrm{n}$ & A1/ B1 \\
\hline 5.5 .1 & 162 & co59_br-usL & $\mathrm{RG}$ & $\begin{array}{l}\text { Personal Identification } \\
\text { NumberEF }\end{array}$ & 3 & $\mathrm{EF}$ & $n$ & $\mathrm{~B} 1$ \\
\hline 5.5 .1 & 163 & dc53_br-usnE & $\overline{\mathrm{RG}}$ & RGEMP & 1 & EMP & $n$ & A1 \\
\hline 5.5 .2 & 164 & dc51_br-usL & $\mathrm{SSP} / \mathrm{SP}$ & $\begin{array}{l}\text { issued byEX the São } \\
\text { Paulo Secretary of } \\
\text { Public SafetyEX-L }\end{array}$ & 4 & EX-L & $n$ & A1 \\
\hline 5.5 .2 & 165 & dc53_br-usnE & expedida pela SSP/SP & $\begin{array}{l}\text { issued by the Public } \\
\text { Security DepartmentM } \\
\text { of the State of São } \\
\text { PauloL-EX } \\
\text { SSP/SPEMP }\end{array}$ & 4 & $\begin{array}{l}\text { EMP- } \\
\text { EX-L- } \\
\text { M }\end{array}$ & $\mathrm{n}$ & A1 \\
\hline 5.5 .2 & 166 & co50_br-usL & SSP-SP (ou XXX/XX) & $\begin{array}{l}\text { SSP-SP EMP (ou } \\
\text { XXX/XXEMP) }\end{array}$ & 1 & EMP & $\mathrm{N}$ & B1 \\
\hline 5.5 .2 & 166 & co55_br-usnH & SSP-SP (ou XXX/XX) & $\begin{array}{l}\text { SSP-SP EMP (ou } \\
\text { XXX/XXEMP) }\end{array}$ & 1 & EMP & $n$ & A1/ B1 \\
\hline 5.5 .2 & 166 & pr52_br-usnM & SSP-SP (ou XXX/XX) & $\begin{array}{l}\text { SSP-SP EMP (ou } \\
\text { XXX/XXEMP) }\end{array}$ & 1 & EMP & $\mathrm{s}$ & $\begin{array}{l}\text { C1/ D1/ } \\
\text { D2 }\end{array}$ \\
\hline 5.5 .2 & 166 & pr53_br-usnM & SSP-SP (ou XXX/XX) & $\begin{array}{l}\text { SSP-SP EMP (ou } \\
\text { XXX/XXEMP) }\end{array}$ & 1 & EMP & $\mathrm{s}$ & $\mathrm{C} 1$ \\
\hline 5.5 .2 & 166 & pr54_br-usnM & SSP-SP (ou XXX/XX) & $\begin{array}{l}\text { SSP-SP EMP (ou } \\
\text { XXX/XXEMP) }\end{array}$ & 1 & EMP & $\mathrm{s}$ & $\mathrm{C} 1$ \\
\hline 5.5 .2 & 167 & pr53_br-usnM & SSP-SP & <omissão> & 3 & O & s & C1 \\
\hline 5.5 .3 & 168 & dc51_br-usL & inscrito na $\mathrm{OAB} / \mathrm{SP}$ n. 0 & $\begin{array}{l}\text { member No. } 0 \text { of the } \\
\text { Brazilian Bar } \\
\text { AssociationEX-EO, São } \\
\text { Paulo State ChapterEX } \\
(\mathrm{OAB} / \mathrm{SP}) \mathrm{EMP}\end{array}$ & 4 & $\begin{array}{l}\text { EMP- } \\
\text { EO-EX }\end{array}$ & $n$ & A1 \\
\hline
\end{tabular}




\begin{tabular}{|c|c|c|c|c|c|c|c|c|}
\hline 5.5 .3 & 169 & pr51_br-usL & OAB-SP N ${ }^{\circ} 0$ & $\begin{array}{l}\text { OAB-SPEMP (Order of } 4 \\
\text { Brazilian LawyersL, } \\
\text { São Paulo, Enrollment } \\
\text { NumberEX) No } 0\end{array}$ & & $\begin{array}{l}\text { EMP- } \\
\text { EX-L }\end{array}$ & $n$ & A1/ C2 \\
\hline 5.5 .3 & 170 & pr51_br-usL & OAB-SP N ${ }^{\circ} 0$ & OAB-SPEMP N ${ }^{\circ} 0$ & 1 & EMP & $n$ & $\mathrm{~A} 1 / \mathrm{C} 2$ \\
\hline 5.5 .3 & 171 & pr50_br-usL & $\begin{array}{l}\text { portadora de RNE } \\
\text { A000000-B }\end{array}$ & $\begin{array}{l}\text { bearer of Brazilian } \\
\text { ResidentM Identity } \\
\text { CardEX (RNE)EMP } \\
\text { A000000-B }\end{array}$ & 4 & $\begin{array}{l}\text { EMP- } \\
\text { EX-M }\end{array}$ & $\mathrm{n}$ & A1/ C2 \\
\hline 5.5 .3 & 172 & dc54_br-usnE & $\begin{array}{l}\text { portador da Cédula de } \\
\text { Identidade RNE } 0\end{array}$ & $\begin{array}{l}\text { holder of foreigners'L } \\
\text { RNEEMP identity } \\
\text { cardL No. } 0\end{array}$ & 4 & EMP-L & $\mathrm{s}$ & A1 \\
\hline 5.5 .3 & 173 & dc53_br-usnE & $\begin{array}{l}\text { portador do RNE } \mathrm{n}^{\circ} 0 \\
\text { expedido pelo DPF }\end{array}$ & $\begin{array}{l}\text { bearer of Identity } \\
\text { CardEX RNEEMP No. } \\
0, \text { issued by the Federal } \\
\text { Police Department } \\
\text { (DPF) }\end{array}$ & 4 & $\begin{array}{l}\text { EMP- } \\
\text { EX }\end{array}$ & $\mathrm{n}$ & A1 \\
\hline \begin{tabular}{|l|}
5.5 .4 \\
\end{tabular} & 174 & co50_us-brL & $\begin{array}{l}\text { arquivado na Junta } \\
\text { Comercial do Estado de } \\
\text { São Paulo ("JUCESP") } \\
\text { sob nº }\end{array}$ & $\begin{array}{l}\text { filed with the São } \\
\text { PauloT State Board of } \\
\text { TradeM (JUCESP)EMP } \\
\text { under No. } 0\end{array}$ & 4 & $\begin{array}{l}\text { EMP- } \\
\text { M-T }\end{array}$ & $\mathrm{N}$ & B1 \\
\hline 5.5 .4 & 175 & pr53_br-usnM & $\begin{array}{l}\text { registrado na JUCESP sob } \\
\text { no. }\end{array}$ & $\begin{array}{l}\text { filed with } \\
\text { JUCESPEMP [Registry } \\
\text { of CommerceEF for the } \\
\text { State of São Paulo]EX } \\
\text { under No. } 0\end{array}$ & 4 & $\begin{array}{l}\text { EF- } \\
\text { EMP- } \\
\text { EX }\end{array}$ & $\mathrm{s}$ & C1 \\
\hline 5.5 .4 & 176 & dc54_br-usnE & JUCESP & $\begin{array}{l}\text { São Paulo State } \\
\text { Division of } \\
\text { CorporationsEX-M }\end{array}$ & 4 & EX-M & $\mathrm{s}$ & A1 \\
\hline \begin{tabular}{|l|}
5.5 .4 \\
\end{tabular} & 177 & dc53_br-usnE & $\begin{array}{l}\text { Junta Comercial do } \\
\text { Estado de São Paulo - } \\
\text { JUCESP }\end{array}$ & \begin{tabular}{|l|l} 
State of São PauloL & 4 \\
Commercial RegistryM & \\
(JUCESPEMP)
\end{tabular} & 4 & $\begin{array}{l}\text { EMP-L- } \\
\mathrm{M}\end{array}$ & $\mathrm{n}$ & A1 \\
\hline \begin{tabular}{|l|}
5.5 .4 \\
\end{tabular} & 178 & co50_br-usL & $\begin{array}{l}\text { inscrita no CGC/MF sob } \\
n^{\circ} 0\end{array}$ & $\begin{array}{l}\text { enrolled in the } \\
\text { BrazilianEX } \\
\text { corporateM }\end{array}$ & 4 & \begin{tabular}{|l|} 
EMP- \\
EF-EX- \\
\end{tabular} & $\mathrm{N}$ & B1 \\
\hline
\end{tabular}




\begin{tabular}{|c|c|c|c|c|c|c|c|c|}
\hline & & & & $\begin{array}{l}\text { taxpayersEF registryL- } \\
\text { EX (CGC)EMP under } \\
\text { No.0 }\end{array}$ & & & & \\
\hline 5.5 .4 & 179 & co59_br-usL & CNPJ & $\begin{array}{l}\text { BrazilianEX } \\
\text { TaxpayerEF } \\
\text { IdentificationM-EX } \\
\text { Number (CNPJ)EMP }\end{array}$ & 4 & $\begin{array}{l}\text { EMP- } \\
\text { EF-EX- } \\
\text { M }\end{array}$ & n & B1 \\
\hline \begin{tabular}{|l|}
5.5 .4 \\
\end{tabular} & 179 & dc50_br-usL & CNPJ & $\begin{array}{l}\text { BrazilianEX } \\
\text { TaxpayerEF } \\
\text { IdentificationM-EX } \\
\text { Number (CNPJ)EMP }\end{array}$ & 4 & $\begin{array}{l}\text { EMP- } \\
\text { EF-EX- } \\
\text { M }\end{array}$ & n & A1 \\
\hline 5.5 .4 & 180 & co54_br-usnF & $\mathrm{CNPJ} / \mathrm{MF}$ & $\begin{array}{l}\text { GeneralM } \\
\text { Taxpayers'EF } \\
\text { RegistryL-EX }\end{array}$ & 3 & $\begin{array}{l}\text { EF-EX- } \\
\text { L-M }\end{array}$ & $\mathrm{N}$ & A1 \\
\hline 5.5 .4 & 181 & dc52_br-usD & CNPJ No. & $\begin{array}{l}\text { taxpayer'sEF-EX } \\
\text { (CNPJ)EMP no. } 0\end{array}$ & 4 & $\begin{array}{l}\text { EMP- } \\
\text { EF-EX }\end{array}$ & n & D3 \\
\hline 5.5 .4 & 182 & dc52_br-usD & CNPJ No. & $\begin{array}{l}\text { taxpayerEF identityM- } \\
\text { EX number } \\
\text { (CNPJ)EMP } 0\end{array}$ & 4 & $\begin{array}{l}\text { EMP- } \\
\text { EF-EX- } \\
\text { M }\end{array}$ & n & D3 \\
\hline 5.5 .4 & 183 & dc53_br-usnE & $\mathrm{CNPJ} / \mathrm{MF} \mathrm{N}^{\circ} 0$ & $\begin{array}{l}\text { CorporateL TaxEF-EX } \\
\text { CNPJ/MFEMP Number } \\
0\end{array}$ & 4 & $\begin{array}{l}\text { EF- } \\
\text { EMP- } \\
\text { EX-L }\end{array}$ & n & A1 \\
\hline 5.5 .4 & 184 & pr51_br-usL & CNPJ & $\begin{array}{l}\text { NationalL CorporateL } \\
\text { Taxpayers'EF } \\
\text { RegisterL-EX } \\
\text { (CNPJ)EMP }\end{array}$ & 4 & $\begin{array}{l}\text { EF- } \\
\text { EMP- } \\
\text { EX-L }\end{array}$ & n & $\mathrm{A} 1 / \mathrm{C} 2$ \\
\hline 5.5 .4 & 185 & co55_br-usnH & CNPJ-MF & $\begin{array}{l}\text { CNPJ-MFEMP } \\
\text { (National Registry of } \\
\text { Legal Entities)L-EX }\end{array}$ & 4 & $\begin{array}{l}\text { EMP- } \\
\text { EX-L }\end{array}$ & n & A1/ B1 \\
\hline 5.5 .4 & 186 & co56-br-usD & $\mathrm{CNPJ} / \mathrm{MF}$ & $\begin{array}{l}\text { National Registry of } \\
\text { Legal EntitiesL-EX } \\
\text { (CNPJ/MF)EMP }\end{array}$ & 4 & $\begin{array}{l}\text { EMP- } \\
\text { EX-L }\end{array}$ & n & A1/ B1 \\
\hline 5.5 .4 & 186 & co57_br-usD & $\overline{\mathrm{CNPJ} / \mathrm{MF}}$ & $\begin{array}{l}\text { National Registry of } \\
\text { Legal EntitiesL-EX }\end{array}$ & 4 & $\begin{array}{l}\text { EMP- } \\
\text { EX-L }\end{array}$ & n & $\mathrm{A} 1 / \mathrm{B} 1$ \\
\hline
\end{tabular}




\begin{tabular}{|c|c|c|c|c|c|c|c|c|}
\hline & & & & (CNPJ/MF)EMP & & & & \\
\hline 5.5 .4 & 186 & co58-br-usD & $\mathrm{CNPJ} / \mathrm{MF}$ & $\begin{array}{l}\text { National Registry of } \\
\text { Legal EntitiesL-EX } \\
\text { (CNPJ/MF)EMP }\end{array}$ & 4 & $\begin{array}{l}\text { EMP- } \\
\text { EX-L }\end{array}$ & n & A1/ B1 \\
\hline 5.5 .4 & 187 & dc51_br-usL & $\mathrm{CNPJ} / \mathrm{MF}$ & $\begin{array}{l}\text { National Register of } \\
\text { Legal EntitiesL-EX } \\
{[\mathrm{CNPJ} / \mathrm{MF}] \mathrm{EMP}}\end{array}$ & 4 & $\begin{array}{l}\text { EMP- } \\
\text { EX-L }\end{array}$ & $\mathrm{n}$ & A1 \\
\hline 5.5 .4 & 188 & pr52_br-usnM & $\begin{array}{l}\text { inscrita no CNPJ/MF sob } \\
\text { no. } 0\end{array}$ & $\begin{array}{l}\text { enrolled in the national } \\
\text { register of legal } \\
\text { entitiesL-EX of the } \\
\text { Brazilian Ministry of } \\
\text { Finance under } \\
\text { CNPJ/MFEMP } 0\end{array}$ & 4 & $\begin{array}{l}\text { EMP- } \\
\text { EX-L }\end{array}$ & s & $\begin{array}{ll}\mathrm{C} 1 / & \mathrm{D} 1 / \\
\mathrm{D} 2\end{array}$ \\
\hline 5.5 .4 & 189 & pr53_br-usnM & inscrita no CNPJ & $\begin{array}{l}\text { enrolled in the } \\
\text { BrazilianEX Registry of } \\
\text { Legal EntitiesL-EX } \\
\text { under No. CNPJEMP } 0\end{array}$ & 4 & $\begin{array}{l}\text { EMP- } \\
\text { EX-L }\end{array}$ & $\mathrm{s}$ & $\mathrm{C} 1$ \\
\hline 5.5 .4 & 190 & pr53_br-usnM & $\mathrm{CNPJ} / \mathrm{MF}$ & $\begin{array}{l}\text { BrazilianEX Registry of } \\
\text { Legal EntitiesL-EX of } \\
\text { the Ministry of Finance }\end{array}$ & & EX-L & $\mathrm{s}$ & $\mathrm{C} 1$ \\
\hline 5.5 .4 & 191 & dc54_br-usnE & inscrita no CNPJ sob $\mathrm{n}^{\circ} 0$ & $\begin{array}{l}\text { registered at the } \\
\text { National Registry of } \\
\text { Legal EntitiesL-EX } \\
\text { (CNPJ)EMP under No. } \\
0\end{array}$ & 4 & $\begin{array}{l}\text { EMP- } \\
\text { EX-L }\end{array}$ & $\mathrm{S}$ & A1 \\
\hline 5.5 .4 & 192 & co60_br-usP & $\begin{array}{l}\text { inscrita(o) no CNPJ/MF } \\
\text { sob o n. }{ }^{\circ} 0\end{array}$ & $\begin{array}{l}\text { registered with the } \\
\text { CNPJ/MFEMP } \\
\text { [National Registry of } \\
\text { Legal EntitiesL- } \\
\text { EX/Treasury Ministry] } \\
\text { under no. } 0\end{array}$ & 4 & $\begin{array}{l}\text { EMP- } \\
\text { EX-L }\end{array}$ & $\mathrm{n}$ & A1 \\
\hline 5.5 .4 & 193 & dc52_br-usD & CNPJ & CNPJEMP & 1 & EMP & n & D3 \\
\hline 5.5 .4 & 193 & dc54_br-usnE & CNPJ & CNPJEMP & 1 & EMP & $\mathrm{s}$ & A1 \\
\hline
\end{tabular}




\begin{tabular}{|c|c|c|c|c|c|c|c|c|}
\hline 5.5 .4 & 193 & pr53_br-usnM & CNPJ & CNPJEMP & 1 & EMP & S & $\mathrm{C} 1$ \\
\hline 6.1 .1 & 1 & pr4_ukn-brM & $\begin{array}{l}\text { IN WITNESS } \\
\text { WHEREOF }\end{array}$ & $\begin{array}{l}\text { Em testemunho do } \\
\text { quêD }\end{array}$ & 2 & $\mathrm{D}$ & $\mathrm{s}$ & D2 \\
\hline 6.1 .1 & 2 & pr1_usn-brM & $\begin{array}{l}\text { IN WITNESS } \\
\text { WHEREOF }\end{array}$ & $\begin{array}{l}\text { EM TESTEMUNHO } \\
\text { DO QUÊD }\end{array}$ & 2 & $\mathrm{D}$ & $\mathrm{s}$ & D2 \\
\hline 6.1 .1 & 3 & dc1_us-brE & $\begin{array}{l}\text { IN WITNESS } \\
\text { WHEREOF }\end{array}$ & $\begin{array}{l}\text { Em testemunho do } \\
\text { quêD }\end{array}$ & 2 & $\mathrm{D}$ & $\mathrm{s}$ & C1 \\
\hline 6.1 .1 & 4 & pr6_ukn-brE & In witness whereof & $\begin{array}{l}\text { Em testemunho do } \\
\text { quêD }\end{array}$ & 2 & $\mathrm{D}$ & $\mathrm{s}$ & D2 \\
\hline 6.1 .1 & 5 & co7_usn-brF & $\begin{array}{l}\text { IN WITNESS OF THIS } \\
\text { AGREEMENT }\end{array}$ & $\begin{array}{l}\text { EM TESTEMUNHO } \\
\text { DO QUÊD }\end{array}$ & 2 & $\mathrm{D}$ & n & A2 \\
\hline 6.1 .1 & 6 & col1_us-brN & $\begin{array}{l}\text { IN WITNESS } \\
\text { WHEREOF }\end{array}$ & $\begin{array}{l}\text { E, por estarem assim, } \\
\text { justas e } \\
\text { contratadasEDV }\end{array}$ & 5 & EDV & $\mathrm{N}$ & B1 \\
\hline 6.1 .1 & 7 & co5_us-brJ & And being thus agreed, & $\begin{array}{l}\text { E, por estarem assim } \\
\text { justas e } \\
\text { contratadasEDV }\end{array}$ & 5 & EDV & $\mathrm{N}$ & D3 \\
\hline 6.1 .1 & 8 & co60_br-usP & $\begin{array}{l}\text { E, por estarem justas e } \\
\text { contratadas, }\end{array}$ & $\begin{array}{l}\text { In witness } \\
\text { whereof,EDV }\end{array}$ & 5 & EDV & n & A1 \\
\hline 6.1 .1 & 8 & dc52_br-usD & $\begin{array}{l}\text { E, por estarem justas e } \\
\text { contratadas, }\end{array}$ & $\begin{array}{l}\text { In witness } \\
\text { whereof,EDV }\end{array}$ & 5 & EDV & n & D3 \\
\hline 6.1 .1 & 8 & dc53_br-usnE & $\begin{array}{l}\text { E, por estarem justas e } \\
\text { contratadas, }\end{array}$ & $\begin{array}{l}\text { In witness } \\
\text { whereof,EDV }\end{array}$ & 5 & EDV & $n$ & A1 \\
\hline 6.1 .1 & 9 & co55_br-usnH & $\begin{array}{l}\text { E, por estarem assim } \\
\text { justas e contratadas, }\end{array}$ & $\begin{array}{l}\text { In witness } \\
\text { whereof,EDV }\end{array}$ & 5 & EDV & $n$ & A1/ B1 \\
\hline \begin{tabular}{|l|}
6.1 .1 \\
\end{tabular} & 9 & co58_br-usD & $\begin{array}{l}\text { E, por estarem assim } \\
\text { justas e contratadas, }\end{array}$ & $\begin{array}{l}\text { In witness } \\
\text { whereof,EDV }\end{array}$ & 5 & EDV & n & A1/B1 \\
\hline \begin{tabular}{|l|}
6.1 .1 \\
\end{tabular} & 9 & co61_br-usQ & $\begin{array}{l}\text { E, por estarem assim } \\
\text { justas e contratadas, }\end{array}$ & $\begin{array}{l}\text { In witness } \\
\text { whereof,EDV }\end{array}$ & 5 & EDV & n & $\mathrm{C} 2$ \\
\hline \begin{tabular}{|l|}
6.1 .1 \\
\end{tabular} & 9 & dc51_br-usL & $\begin{array}{l}\text { E, por estarem assim } \\
\text { justas e contratadas, }\end{array}$ & $\begin{array}{l}\text { In witness } \\
\text { whereof,EDV }\end{array}$ & 5 & EDV & n & A1 \\
\hline 6.1 .1 & 10 & co57_br-usD & $\begin{array}{l}\text { E, por assim estarem } \\
\text { justas e contratadas, }\end{array}$ & $\begin{array}{l}\text { In witness } \\
\text { whereof,EDV }\end{array}$ & 5 & EDV & n & A1/ B1 \\
\hline 6.1 .1 & 11 & co56_br-usD & $\begin{array}{l}\text { E, por estarem assim } \\
\text { justas e avençadas, }\end{array}$ & $\begin{array}{l}\text { In witness whereof, the } \\
\text { partiesEDV }\end{array}$ & 5 & EDV & n & A1/ B1 \\
\hline
\end{tabular}




\begin{tabular}{|c|c|c|c|c|c|c|c|c|}
\hline 6.1 .1 & 12 & co52_br-usK & $\begin{array}{l}\text { E, por estarem assim } \\
\text { justos e contratados, }\end{array}$ & $\begin{array}{l}\text { And in witness whereof } \\
\text { EDV }\end{array}$ & & EDV & $\mathrm{n}$ & A2 \\
\hline 6.1 .1 & 13 & co61_br-usQ & $\begin{array}{l}\text { E por estarem, assim, } \\
\text { justas e contratadas }\end{array}$ & $\begin{array}{l}\text { In witness } \\
\text { whereof,EDV }\end{array}$ & 5 & EDV & $\mathrm{n}$ & $\mathrm{C} 2$ \\
\hline 6.1 .1 & 14 & dc54_br-usnE & $\begin{array}{l}\text { E por se acharem em } \\
\text { perfeito acordo }\end{array}$ & In witness hereofEDV & 5 & EDV & $\mathrm{s}$ & A1 \\
\hline 6.1 .1 & 15 & co51_br-usD & $\begin{array}{l}\text { E, por estarem assim } \\
\text { justas e avençadas, }\end{array}$ & $\begin{array}{l}\text { The parties, hereby } \\
\text { undertake and agreeM }\end{array}$ & 3 & $M$ & $\mathrm{n}$ & $\mathrm{A} 1 / \mathrm{B} 1$ \\
\hline 6.1 .1 & 16 & co50_br-usL & $\begin{array}{l}\text { E, por estarem assim } \\
\text { justas e contratadas, }\end{array}$ & $\begin{array}{l}\text { And, thus considered } \\
\text { just and agreed,M }\end{array}$ & 2 & $\mathrm{M}$ & $\mathrm{N}$ & B1 \\
\hline 6.1 .1 & 17 & co52_br-usK & $\begin{array}{l}\text { têm entre si justo e } \\
\text { contratado o seguinte }\end{array}$ & $\begin{array}{l}\text { in witness whereofEDV } \\
\text { agree to the followingL }\end{array}$ & 2 & EDV-L & $\mathrm{n}$ & A2 \\
\hline 6.1 .1 & 18 & dc52_br-usD & $\begin{array}{l}\text { Assim, estando todos os } \\
\text { sócios de acordo, }\end{array}$ & $\begin{array}{l}\text { In witness } \\
\text { whereofEDV-ER, the } \\
\text { parties, being in } \\
\text { agreement, }\end{array}$ & 2 & $\begin{array}{l}\text { EDV- } \\
\text { ER }\end{array}$ & $\mathrm{n}$ & D3 \\
\hline 6.1 .1 & 19 & pr53_br-usnM & $\begin{array}{l}\text { pediu-me e eu lhe lavrei } \\
\text { este instrumento ... dou fé. }\end{array}$ & $\begin{array}{l}\text { In witness whereofM, } \\
\text { as requested, I have } \\
\text { drawn up this deed, }\end{array}$ & 5 & $M$ & $\mathrm{~s}$ & $\mathrm{C} 1$ \\
\hline 6.1 .2 & 20 & pr1_usn-brM & $\begin{array}{l}\text { KNOW ALL MEN BY } \\
\text { THESE PRESENTS that }\end{array}$ & $\begin{array}{l}\text { SAIBAM QUANTOS } \\
\text { A PRESENTE VIREM } \\
\text { queEDV, }\end{array}$ & 5 & EDV & $\mathrm{s}$ & $\mathrm{D} 2$ \\
\hline 6.1 .2 & 21 & pr54_br_usnM & $\begin{array}{l}\text { Saibam, quantos este } \\
\text { público instrumento de } \\
\text { procuração virem que, }\end{array}$ & $\begin{array}{l}\text { KNOW ALL } \\
\text { PERSONSEDV to } \\
\text { whom this notarized } \\
\text { power of attorney may } \\
\text { come that }\end{array}$ & 5 & EDV & s & $\mathrm{C} 1$ \\
\hline 6.1 .2 & 22 & pr53_br-usnM & $\begin{array}{l}\text { SAIBAM quantos este } \\
\text { público instrumento de } \\
\text { procuração bastante virem } \\
\text { que, }\end{array}$ & $\begin{array}{l}\text { KNOW ALL } \\
\text { PERSONSEDV to } \\
\text { whom this power of } \\
\text { attorney granted } \\
\text { through public deed } \\
\text { may come that }\end{array}$ & 5 & EDV & $\mathrm{s}$ & $\mathrm{C} 1$ \\
\hline
\end{tabular}




\begin{tabular}{|c|c|c|c|c|c|c|c|c|}
\hline 6.1 .3 & 23 & co53_br-usnF & $\begin{array}{l}\text { <qualificações das partes> } \\
\text { PREÂMBULO: } \\
\text { Considerando: Que as } \\
\text { Partes celebraram }\end{array}$ & $\begin{array}{l}\text { <qualificações das } \\
\text { partes> } \\
\text { WITNESSETHEDV: } \\
\text { Whereas the Parties } \\
\text { executed }\end{array}$ & 5 & EDV & s & D2 \\
\hline 6.1 .4 & 24 & col1_us-brN & WHEREAS & $\begin{array}{l}\text { CONSIDERANDO } \\
\text { QUEL }\end{array}$ & 5 & $\mathrm{~L}$ & $\mathrm{~N}$ & B1 \\
\hline 6.1 .4 & 25 & col1_us-brN & $\begin{array}{l}\text { NOW, THEREFORE, in } \\
\text { consideration of... }\end{array}$ & $\begin{array}{l}\text { <omissão>Tendo em } \\
\text { vista as... }\end{array}$ & 5 & $\mathrm{O}$ & $\mathrm{N}$ & B1 \\
\hline 6.1 .4 & 26 & co7_usn-brF & WHEREAS & $\begin{array}{l}\text { CONSIDERANDO } \\
\text { QUEL }\end{array}$ & 5 & $\mathrm{~L}$ & n & A2 \\
\hline 6.1 .4 & 27 & co7_usn-brF & $\begin{array}{l}\text { and now therefore, } \\
\text { Company1 and } \\
\text { Company } 2 \text { agree as } \\
\text { follows }\end{array}$ & $\begin{array}{l}<\text { omissão }>\text { as partes } \\
\text { qualificadas supra têm } \\
\text { entre si justo e acordado } \\
\text { o que segue }\end{array}$ & 5 & $\mathrm{O}$ & n & A2 \\
\hline 6.1 .4 & 28 & co56_br-usD & CONSIDERANDO QUE & WHEREASL & 5 & $\mathrm{~L}$ & $\mathrm{~N}$ & A1/ B1 \\
\hline 6.1 .4 & 28 & co57_br-usD & CONSIDERANDO QUE & WHEREASL & 5 & $\mathrm{~L}$ & n & A1/ B1 \\
\hline 6.1 .4 & 28 & co58_br-usD & CONSIDERANDO QUE & WHEREASL & 5 & $\mathrm{~L}$ & n & A1/ B1 \\
\hline 6.1 .4 & 28 & co60_br-usP & CONSIDERANDO QUE & WHEREASL & 5 & $\mathrm{~L}$ & n & A1 \\
\hline 6.1 .4 & 29 & co53_br-usnF & Considerando: & WhereasL & 5 & $\mathrm{~L}$ & s & D2 \\
\hline 6.1 .4 & 30 & co60_br-usP & CONSIDERANDO QUE & WHEREASL & 5 & $\mathrm{~L}$ & n & A1 \\
\hline 6.1 .5 & 31 & dc1_us-brE & $\begin{array}{l}\text { IN WITNESS } \\
\text { WHEREOF, the } \\
\text { undersigned hereunto set } \\
\text { his hand this }<\text { date }>\end{array}$ & $\begin{array}{l}\text { Em testemunho do quê, } \\
\text { o abaixo-assinado } \\
\text { firmouEF este } \\
\text { documento no }<\text { data }>\end{array}$ & 3 & EF & $\mathrm{s}$ & C1 \\
\hline 6.1 .6 & 32 & pr53_br-usnM & $\begin{array}{l}\text { Assim, disse do que dou } \\
\text { fé; }\end{array}$ & $\begin{array}{l}\text { These were the } \\
\text { statements made, which } \\
\text { I certifyEO. }\end{array}$ & 3 & EO & $\mathrm{S}$ & C1 \\
\hline 6.1 .6 & 33 & pr54_br-usnM & do que dou fé. & which I certifyEO. & 3 & EO & $\mathrm{s}$ & $\mathrm{C} 1$ \\
\hline 6.1 .6 & 34 & pr54_br-usnM & $\begin{array}{l}\text { E, de como assim o disse, } \\
\text { dou fé. }\end{array}$ & $\begin{array}{l}\text { And I certifyEO that } \\
\text { these were the words } \\
\text { declared by the }\end{array}$ & 3 & EO & $\mathrm{s}$ & $\mathrm{C} 1$ \\
\hline
\end{tabular}




\begin{tabular}{|c|c|c|c|c|c|c|c|c|}
\hline & & & & Appointor. & & & & \\
\hline 6.1 .7 & 35 & co51_br-usD & $\begin{array}{l}\text { e na melhor forma de } \\
\text { direito }\end{array}$ & and pursuant to lawM & 3 & $\mathrm{M}$ & $n$ & A1/ B1 \\
\hline 6.1 .7 & 36 & co55_br-usnH & $\begin{array}{l}\text { e na melhor forma de } \\
\text { direito }\end{array}$ & $\begin{array}{l}\text { and in the due form of } \\
\text { the lawM }\end{array}$ & 2 & $\mathrm{M}$ & n & A1/B1 \\
\hline 6.1 .7 & 37 & pr53_br-usnM & e melhor forma de direito & $\begin{array}{l}\text { and in the due form of } \\
\text { lawM }\end{array}$ & 2 & $M$ & $\mathrm{~s}$ & $\mathrm{C} 1$ \\
\hline 6.1 .7 & 38 & co56_br-usD & $\begin{array}{l}\text { e na melhor forma de } \\
\text { direito }\end{array}$ & $\begin{array}{l}\text { and in the best form of } \\
\text { the lawL }\end{array}$ & 2 & $M$ & $n$ & $\mathrm{~A} 1 / \mathrm{B} 1$ \\
\hline 6.1 .7 & 38 & co57_br-usD & $\begin{array}{l}\text { e na melhor forma de } \\
\text { direito }\end{array}$ & $\begin{array}{l}\text { and in the best form of } \\
\text { the lawL }\end{array}$ & 2 & $M$ & $\mathrm{n}$ & A1/ B1 \\
\hline 6.1 .7 & 38 & co58_br-usD & $\begin{array}{l}\text { e na melhor forma de } \\
\text { direito }\end{array}$ & $\begin{array}{l}\text { and in the best form of } \\
\text { the lawL }\end{array}$ & 2 & $\mathrm{M}$ & $\mathrm{n}$ & A1/ B1 \\
\hline 6.1 .7 & 39 & pr54_br-usnM & e melhor forma de direito & $\begin{array}{l}\text { and pursuant to all } \\
\text { applicable lawsM }\end{array}$ & 3 & $M$ & $\mathrm{~s}$ & $\mathrm{C} 1$ \\
\hline 6.1 .7 & 40 & pr9_usn-brB & in its best rightful form & $\begin{array}{l}\text { na melhor forma do } \\
\text { direitoM }\end{array}$ & 5 & $M$ & $\mathrm{~s}$ & D2 \\
\hline 6.1 .8 & 41 & dc2_uk-brB & aforesaid & acima mencionados $\mathrm{L}$ & 3 & $\mathrm{~L}$ & $\mathrm{~s}$ & $\mathrm{C} 1$ \\
\hline 6.1 .8 & 42 & dc3_uk-brE & aforesaid & descritos acimaM & 3 & $M$ & $\mathrm{~s}$ & $\mathrm{C} 1$ \\
\hline 6.1 .8 & 43 & dc4_uk-brE & aforesaid & exposto acimaM & 3 & $\mathrm{M}$ & $\mathrm{s}$ & $\mathrm{C} 1$ \\
\hline 6.1 .8 & 44 & dc4_uk-brE & aforesaid & acima expostoM & 3 & $M$ & $\mathrm{~s}$ & $\mathrm{C} 1$ \\
\hline 6.1 .8 & 45 & pr4_ukn-brM & aforesaid & supracitadasL & 3 & $\mathrm{~L}$ & $\mathrm{~s}$ & D2 \\
\hline 6.1 .8 & 46 & co53_br-usnF & acima mencionado & aforesaidL & 3 & $\mathrm{~L}$ & $\mathrm{~s}$ & D2 \\
\hline 6.1 .8 & 47 & co53_br-usnF & acima & aforesaidM & 3 & $\mathrm{M}$ & $\mathrm{s}$ & D2 \\
\hline 6.1 .8 & 48 & co53_br-usnF & no prazo determinado & $\begin{array}{l}\text { within the term } \\
\text { aforesaidM }\end{array}$ & 5 & $M$ & $\mathrm{~s}$ & D2 \\
\hline 6.1 .8 & 49 & co53_br-usnF & citada & aforesaidM & 5 & $M$ & $\mathrm{~s}$ & D2 \\
\hline 6.1 .8 & 50 & co54_br-usnF & referido & aforesaidM & 5 & $\mathrm{M}$ & $\mathrm{N}$ & A1 \\
\hline 6.1 .9 & 51 & pr51_br-usL & $\begin{array}{l}\text { seus bastante } \\
\text { procuradores }\end{array}$ & $\begin{array}{l}\text { its true and lawfulEDV } \\
\text { attorneys }\end{array}$ & 5 & EDV & $n$ & A1/ C2 \\
\hline 6.1 .9 & 52 & pr52_br-usnM & seu bastante procurador & $\begin{array}{l}\text { its true and lawfulEDV } \\
\text { Attorney }\end{array}$ & 5 & EDV & $\mathrm{s}$ & $\begin{array}{ll}\mathrm{C} 1 / \mathrm{D} 1 / \\
\mathrm{D} 2\end{array}$ \\
\hline
\end{tabular}




\begin{tabular}{|c|c|c|c|c|c|c|c|c|}
\hline 6.1 .9 & 53 & pr54_br-usnM & sua bastante procuradora & $\begin{array}{l}\text { his true and lawfulEDV } \\
\text { attorney in fact }\end{array}$ & 5 & EDV & $\mathrm{s}$ & $\mathrm{C} 1$ \\
\hline 6.1 .9 & 54 & co50_br-usL & $\begin{array}{l}\text { seus bastantes } \\
\text { procuradores }\end{array}$ & $\begin{array}{l}\text { its true and lawfulEDV } \\
\text { attorneys, }\end{array}$ & 5 & EDV & $\mathrm{N}$ & B1 \\
\hline 6.1 .9 & 55 & pr50_br-usL & meu bastante procurador & my Attorney-in-FactI & 5 & $\mathrm{I}$ & $\mathrm{n}$ & $\mathrm{A} 1 / \mathrm{C} 2$ \\
\hline 6.1 .9 & 56 & pr53_br-usnM & seus procuradores & $\begin{array}{l}\text { its true and lawfulEDV } \\
\text { attorneys in fact }\end{array}$ & 5 & EDV & $\mathrm{s}$ & C1 \\
\hline 6.1 .9 & 57 & pr1_usn-brM & attorney-in-fact & $\begin{array}{l}\text { bastanteEDV } \\
\text { procurador }\end{array}$ & 5 & EDV & $\mathrm{s}$ & D2 \\
\hline 6.1 .9 & 58 & pr2_us-brM & $\begin{array}{l}\text { as my Attorney-in-Fact } \\
\text { ("Agent"). }\end{array}$ & $\begin{array}{l}\text { como minha } \\
\text { bastanteEDV } \\
\text { procuradora .... } \\
\text { ("Procuradora") }\end{array}$ & 5 & EDV & $\mathrm{s}$ & C1 \\
\hline 6.1 .9 & 59 & co2_us-brG & attorney-in-fact & $\begin{array}{l}\text { bastanteEDV } \\
\text { procurador }\end{array}$ & 5 & EDV & $\mathrm{N}$ & $\mathrm{B} 1$ \\
\hline 6.1 .9 & 60 & pr5_usn-brE & $\begin{array}{l}\text { its true and lawful } \\
\text { Attorney }\end{array}$ & $\begin{array}{l}\text { seu bastanteEDV } \\
\text { procurador Person2 }\end{array}$ & 5 & EDV & $\mathrm{s}$ & D2 \\
\hline 6.1 .9 & 61 & pr4_ukn-brM & $\begin{array}{l}\text { its true and lawful } \\
\text { attorney-in-fact }\end{array}$ & $\begin{array}{l}\text { seus verdadeiros e } \\
\text { legítimosL } \\
\text { bastantesEDV } \\
\text { procuradores }\end{array}$ & 2 & EDV-L & $\mathrm{s}$ & D2 \\
\hline 6.1 .9 & 62 & pr1_usn-brM & $\begin{array}{l}\text { the true and lawful } \\
\text { Attorney-in-Fact }\end{array}$ & $\begin{array}{l}\text { como verdadeiro e } \\
\text { legítimo bastanteEDV } \\
\text { procurador }\end{array}$ & 2 & EDV & $\mathrm{s}$ & D2 \\
\hline 6.2 .1 & 63 & dc2_uk-brB & $\begin{array}{l}\text { has such powers and } \\
\text { authorities }\end{array}$ & $\begin{array}{l}\text { terá os poderes e a } \\
\text { autoridadeL }\end{array}$ & 3 & $\mathrm{~L}$ & $\mathrm{~s}$ & C1 \\
\hline 6.2 .1 & 63 & dc4_uk-brB & $\begin{array}{l}\text { has such powers and } \\
\text { authorities }\end{array}$ & $\begin{array}{l}\text { terá os poderes e a } \\
\text { autoridadeL }\end{array}$ & 3 & $\mathrm{~L}$ & $\mathrm{~s}$ & C1 \\
\hline 6.2 .1 & 64 & co6_us-brA & $\begin{array}{l}\text { full legal power and } \\
\text { authority }\end{array}$ & $\begin{array}{l}\text { poder e autoridadeL } \\
\text { legal plena }\end{array}$ & 3 & $\mathrm{~L}$ & n & B1 \\
\hline 6.2 .1 & 65 & pr1_usn-brM & $\begin{array}{l}\text { with the powers and } \\
\text { authorities }\end{array}$ & $\begin{array}{l}\text { com os poderes e a } \\
\text { competênciaL }\end{array}$ & 3 & $\mathrm{~L}$ & $\mathrm{~s}$ & D2 \\
\hline 6.2 .1 & 66 & pr2_us-brM & $\begin{array}{l}\text { My Agent shall have full } \\
\text { power and authority }\end{array}$ & $\begin{array}{l}\text { Minha Procuradora terá } \\
\text { plenos poderes e plena }\end{array}$ & 3 & $\mathrm{~L}$ & $\mathrm{~s}$ & C1 \\
\hline
\end{tabular}




\begin{tabular}{|c|c|c|c|c|c|c|c|c|}
\hline & & & & competênciaL & & & & \\
\hline 6.2 .1 & 67 & co2_us-brG & full power and authority & $\begin{array}{l}\text { plenos poderes e } \\
\text { competênciaL }\end{array}$ & 3 & $\mathrm{~L}$ & $\mathrm{~N}$ & B1 \\
\hline 6.2 .1 & 68 & pr2_us-brM & Any power or authority & $\begin{array}{l}\text { Todo poder ouL toda } \\
\text { autorizaçãoM }\end{array}$ & 3 & $\mathrm{~L}$ & $\mathrm{~s}$ & $\mathrm{C} 1$ \\
\hline 6.2 .1 & 69 & co2_us-brG & full power and authority & plenos poderesI para & 5 & $\mathrm{I}$ & $\mathrm{N}$ & B1 \\
\hline 6.2 .2 & 70.1 & co7_usn_brF & enter into force and effect & entrará em vigorI-L & 5 & $\mathrm{I}-\mathrm{L}$ & $n$ & A2 \\
\hline 6.2 .2 & 70.2 & co7_usn_brF & $\begin{array}{l}\text { and shall remain into } \\
\text { force and effect }\end{array}$ & $\begin{array}{l}\text { e permanecerá } \\
\text { vigenteI-L }\end{array}$ & 5 & $\mathrm{I}-\mathrm{L}$ & n & A2 \\
\hline 6.2 .2 & 76 & dc2_uk-brB & force and validity & força e validadeL & 3 & $\mathrm{~L}$ & $\mathrm{~s}$ & $\mathrm{C} 1$ \\
\hline 6.2 .2 & 76 & dc4_uk-brE & force and validity & força e validadeL & 3 & $\mathrm{~L}$ & $\mathrm{~s}$ & $\mathrm{C} 1$ \\
\hline 6.2 .2 & 77 & co52_br-usK & $\begin{array}{l}\text { nenhum efeito e/ou } \\
\text { validade }\end{array}$ & $\begin{array}{l}\text { no longer effective } \\
\text { and/or validL }\end{array}$ & 3 & $\mathrm{~L}$ & n & A2 \\
\hline 6.2 .3 & 78 & co7_usn-brF & $\begin{array}{l}\text { This Agreement is made } \\
\text { this } 0 \text { day of XX } 0000 \text { by } \\
\text { and between }\end{array}$ & $\begin{array}{l}\text { Firmam o presente } \\
\text { Termo, aos } 0 \text { dias de } \\
\text { XX de } 0000 \text { as Partes } \\
\text { <implicitação> }\end{array}$ & 5 & $\mathrm{I}$ & n & A2 \\
\hline 6.2 .3 & 79 & dc52_br-usD & estipulado entre as sócias & $\begin{array}{l}\text { agreed to by and } \\
\text { betweenEDV the } \\
\text { quotaholders }\end{array}$ & 5 & EDV & $n$ & D3 \\
\hline 6.2 .3 & 80 & co58_br-usD & celebrado entre as partes & $\begin{array}{l}\text { entered into by and } \\
\text { betweenEDV the parties }\end{array}$ & 5 & EDV & $n$ & $\mathrm{~A} 1 / \mathrm{B} 1$ \\
\hline 6.2 .3 & 81 & co56_br-usD & celebrado entre & $\begin{array}{l}\text { entered into by and } \\
\text { betweenEDV }\end{array}$ & 5 & EDV & n & A1/ B1 \\
\hline 6.2 .3 & 82 & co53_br-usnF & $\begin{array}{l}\text { de um lado ... e, de outro } \\
\text { lado }\end{array}$ & by and between EDV & 5 & EDV & $\mathrm{s}$ & D2 \\
\hline 6.2 .4 & 83 & co11_us-brN & terms and conditions & termos e condições & 5 & $\mathrm{~L}$ & $\mathrm{~N}$ & B1 \\
\hline 6.2 .4 & 83 & co2_us-brG & terms and conditions & termos e condições & 5 & $\mathrm{~L}$ & $\mathrm{~N}$ & B1 \\
\hline 6.2 .4 & 83 & co4_us-brJ & terms and conditions & termos e condições & 5 & $\mathrm{~L}$ & $\mathrm{~N}$ & A1/ B1 \\
\hline 6.2 .4 & 83 & co5_us-brJ & terms and conditions & termos e condições & 5 & $\mathrm{~L}$ & $\mathrm{~N}$ & D3 \\
\hline 6.2 .4 & 83 & co6_us-brA & terms and conditions & termos e condições & 5 & $\mathrm{~L}$ & n & B1 \\
\hline
\end{tabular}




\begin{tabular}{|c|c|c|c|c|c|c|c|c|}
\hline 6.2 .4 & 83 & co7_usn-brF & terms and conditions & termos e condições & 5 & $\mathrm{~L}$ & n & A2 \\
\hline 6.2 .4 & 83 & dc2_uk-brB & terms and conditions & termos e condições & 5 & $\mathrm{~L}$ & $\mathrm{~s}$ & $\mathrm{C} 1$ \\
\hline 6.2 .4 & 83 & dc3_uk-brE & terms and conditions & termos e condições & 5 & $\mathrm{~L}$ & $\mathrm{~s}$ & $\mathrm{C} 1$ \\
\hline 6.2 .4 & 84 & dc4_uk-brE & $\begin{array}{l}\text { on such terms and } \\
\text { conditions }\end{array}$ & nas condições e termos & 5 & $\mathrm{~L}$ & $\mathrm{~s}$ & $\mathrm{C} 1$ \\
\hline 6.2 .4 & 85 & co7_usn-brF & $\begin{array}{l}\text { in accordance with the } \\
\text { terms and conditions of } \\
\text { this Agreement, }\end{array}$ & $\begin{array}{l}\text { em estrita conformidade } \\
\text { com o dispostoM neste } \\
\text { Termo, }\end{array}$ & 5 & $M$ & n & A2 \\
\hline 6.2 .4 & 86.1 & dc3_uk-brE & $\begin{array}{l}\text { To acquire and undertake } \\
\text { on any terms }\end{array}$ & $\begin{array}{l}\text { Adquirir e empreender } \\
\text { sob quaisquer } \\
\text { condiçõesL }\end{array}$ & 5 & $\mathrm{~L}$ & $\mathrm{~s}$ & $\mathrm{C} 1$ \\
\hline 6.2 .4 & 86.2 & dc3_uk-brE & $\begin{array}{l}\text { and subject to any } \\
\text { conditions }\end{array}$ & $\begin{array}{l}\text { e sujeito a quaisquer } \\
\text { condiçõesL }\end{array}$ & 5 & $\mathrm{~L}$ & $\mathrm{~s}$ & $\mathrm{C} 1$ \\
\hline 6.2 .5 & 90 & co51_us-brD & $\begin{array}{l}\text { em bom estado de } \\
\text { conservação, livre e } \\
\text { desimpedido de coisas e } \\
\text { pessoas }\end{array}$ & $\begin{array}{l}\text { in good condition, free } \\
\text { and unencumberedL of } \\
\text { things or people, }\end{array}$ & 3 & $\mathrm{~L}$ & n & A1/ B1 \\
\hline 6.2 .5 & 91 & co59_br-usL & $\begin{array}{l}\text { de execução dos } \\
\text { trabalhos, deixando-o } \\
\text { livre e desimpedido de } \\
\text { pessoas e coisas, }\end{array}$ & $\begin{array}{l}\text { where work is } \\
\text { performed, leaving it } \\
\text { vacantI of people and } \\
\text { moveable property, }\end{array}$ & 3 & I & n & B1 \\
\hline 6.2 .5 & 92 & co50_br-usL & $\begin{array}{l}\text { até a real e efetiva entrega } \\
\text { do imóvel pelos } \\
\text { LOCADORES à } \\
\text { LOCATÁRIA livre de } \\
\text { pessoas e coisas. }\end{array}$ & $\begin{array}{l}\text { as the real and effective } \\
\text { transfer of possession of } \\
\text { the property to the } \\
\text { TENANT by the } \\
\text { OWNERS, freeL of } \\
\text { people and objects. }\end{array}$ & 3 & $\mathrm{~L}$ & $\mathrm{~N}$ & B1 \\
\hline 6.2 .5 & 93 & co3_us-brG & $\begin{array}{l}\text { shall be made free and } \\
\text { clear of }\end{array}$ & $\begin{array}{l}\text { serão livres e isentosL e } \\
\text { de }\end{array}$ & 5 & $\mathrm{~L}$ & $\mathrm{~N}$ & B1 \\
\hline 6.2 .5 & 94 & co3_us-brG & $\begin{array}{l}\text { free and clear of, and } \\
\text { without deduction for, any }\end{array}$ & $\begin{array}{l}\text { livres e } \\
\text { desembaraçadosL e sem } \\
\text { dedução de quaisquer }\end{array}$ & 5 & $\mathrm{~L}$ & $\mathrm{~N}$ & B1 \\
\hline 6.2 .5 & 95 & co8_us-brF & free from defects & $\begin{array}{l}\text { livre e isentoEDV de } \\
\text { falhas }\end{array}$ & 5 & EDV & n & A2 \\
\hline
\end{tabular}




\begin{tabular}{|c|c|c|c|c|c|c|c|c|}
\hline 6.3 .1 & 96 & $\operatorname{co5} 4 n$ & $\begin{array}{l}\text { residente(s) e } \\
\text { domiciliado(a)(os) }\end{array}$ & resident and domiciledL & 3 & $\mathrm{~L}$ & $\mathrm{~N}$ & A1 \\
\hline 6.3 .1 & 96 & co50_br-usL & $\begin{array}{l}\text { residente(s) e } \\
\text { domiciliado(a)(os) }\end{array}$ & resident and domiciledL & 3 & $\mathrm{~L}$ & $\mathrm{~N}$ & B1 \\
\hline 6.3 .1 & 96 & dc51_br-usL & $\begin{array}{l}\text { residente(s) e } \\
\text { domiciliado(a)(os) }\end{array}$ & resident and domiciledL & 3 & $\mathrm{~L}$ & n & A1 \\
\hline 6.3 .1 & 96 & dc52_br-usD & $\begin{array}{l}\text { residente(s) e } \\
\text { domiciliado(a)(os) }\end{array}$ & resident and domiciledL & 3 & $\mathrm{~L}$ & n & D3 \\
\hline 6.3 .1 & 96 & dc53_br-usnE & $\begin{array}{l}\text { residente(s) e } \\
\text { domiciliado(a)(os) }\end{array}$ & resident and domiciledL & 3 & $\mathrm{~L}$ & n & A1 \\
\hline 6.3 .1 & 96 & dc54_br-usnE & $\begin{array}{l}\text { residente(s) e } \\
\text { domiciliado(a)(os) }\end{array}$ & resident and domiciledL & 3 & $\mathrm{~L}$ & $\mathrm{~s}$ & A1 \\
\hline 6.3 .1 & 96 & pr53_br-usnM & $\begin{array}{l}\text { residente(s) e } \\
\text { domiciliado(a)(os) }\end{array}$ & resident and domiciledL & 3 & $\mathrm{~L}$ & $\mathrm{~s}$ & $\mathrm{C} 1$ \\
\hline 6.3 .1 & 96 & pr54_br-usnM & $\begin{array}{l}\text { residente(s) e } \\
\text { domiciliado(a)(os) }\end{array}$ & resident and domiciledL & 3 & $\mathrm{~L}$ & $\mathrm{~s}$ & $\mathrm{C} 1$ \\
\hline 6.3 .1 & 96 & pr51_br-usL & $\begin{array}{l}\text { residente(s) e } \\
\text { domiciliado(a)(os) }\end{array}$ & resident and domiciledL & 3 & $\mathrm{~L}$ & n & $\mathrm{A} 1 / \mathrm{C} 2$ \\
\hline 6.3 .1 & 97 & co55_br-usnH & domiciliado & domiciledL & 3 & $\mathrm{~L}$ & n & $\mathrm{A} 1 / \mathrm{B} 1$ \\
\hline 6.3 .1 & 97 & dc52_br-usD & domiciliado & domiciledL & 3 & $\mathrm{~L}$ & n & D3 \\
\hline 6.3 .1 & 97 & dc53_br-usnE & domiciliado & domiciledL & 3 & $\mathrm{~L}$ & n & A1 \\
\hline 6.3 .1 & 97 & pr53_br-usnM & domiciliado & domiciledL & 3 & $\mathrm{~L}$ & $\mathrm{~S}$ & $\mathrm{C} 1$ \\
\hline 6.3 .1 & 98 & dc54_br-usnE & residente & residentL & 3 & $\mathrm{~L}$ & $\mathrm{~S}$ & A1 \\
\hline 6.3 .1 & 98 & pr50_br-usL & residente & residentL & 3 & $\mathrm{~L}$ & n & $\mathrm{A} 1 / \mathrm{C} 2$ \\
\hline 6.3 .1 & 99 & pr52_br-usnM & domiciliado e residente & resident and domiciledL & 3 & $\mathrm{~L}$ & $\mathrm{~s}$ & $\begin{array}{l}\mathrm{C} 1 / \mathrm{D} 1 / \\
\mathrm{D} 2\end{array}$ \\
\hline 6.3 .1 & 100 & dc51_br-usL & domiciliado & $\begin{array}{l}\text { resident and } \\
\text { domiciledEDV }\end{array}$ & 3 & EDV & n & A1 \\
\hline 6.3 .1 & 101 & pr8_ukn-brH & resident and domiciled & $\begin{array}{l}\text { residente e } \\
\text { domiciliado(a)L }\end{array}$ & 5 & $\mathrm{~L}$ & n & D3 \\
\hline 6.3 .1 & 101 & pr3_us-brB & resident and domiciled & $\begin{array}{l}\text { residente e } \\
\text { domiciliado(a)L }\end{array}$ & 5 & $\mathrm{~L}$ & $\mathrm{~s}$ & $\mathrm{C} 1 / \mathrm{D} 2$ \\
\hline 6.3 .1 & 101 & pr4_ukn-brM & resident and domiciled & $\begin{array}{l}\text { residente e } \\
\text { domiciliado(a)L }\end{array}$ & 5 & $\mathrm{~L}$ & $\mathrm{~s}$ & D2 \\
\hline
\end{tabular}




\begin{tabular}{|c|c|c|c|c|c|c|c|c|}
\hline 6.3 .1 & 101 & pr6_ukn-brE & resident and domiciled & $\begin{array}{l}\text { residente } \mathrm{e} \\
\text { domiciliado(a)L }\end{array}$ & 5 & $\mathrm{~L}$ & $\mathrm{~s}$ & $\mathrm{D} 2$ \\
\hline 6.3 .1 & 102 & pr5_usn-brE & resident and domiciled & $\begin{array}{l}\text { domiciliado e } \\
\text { residenteL }\end{array}$ & 5 & $\mathrm{~L}$ & $\mathrm{~s}$ & $\mathrm{D} 2$ \\
\hline 6.3 .1 & 103 & p7_ukn-brnL & resident and living & $\begin{array}{l}\text { residente e } \\
\text { domiciliadoL }\end{array}$ & 5 & $\mathrm{~L}$ & n & D3 \\
\hline 6.3 .2 & 104 & pr53_br-usnM & $\begin{array}{l}\text { nomeia e constitui seus } \\
\text { procuradores }\end{array}$ & $\begin{array}{l}\text { appointsEDV its true } \\
\text { and lawful attorneys in } \\
\text { fact }\end{array}$ & 5 & EDV & $\mathrm{s}$ & $\mathrm{C} 1$ \\
\hline 6.3 .2 & 105 & pr54_br-usnM & $\begin{array}{l}\text { nomeia e constitui sua } \\
\text { bastante procuradora }\end{array}$ & $\begin{array}{l}\text { appointsEDV his true } \\
\text { and lawful attorney in } \\
\text { fact }\end{array}$ & 5 & EDV & $\mathrm{s}$ & $\mathrm{C} 1$ \\
\hline 6.3 .2 & 106 & pr51_br-usL & $\begin{array}{l}\text { nomeia e constitui seus } \\
\text { bastante procuradores }\end{array}$ & $\begin{array}{l}\text { appointsEDV as its true } \\
\text { and lawful attorneys }\end{array}$ & 5 & EDV & $\mathrm{n}$ & $\mathrm{A} 1 / \mathrm{C} 2$ \\
\hline 6.3 .2 & 107 & co52_br-usK & nomeia o representante & appointsL the Agent & 5 & $\mathrm{~L}$ & n & A2 \\
\hline 6.3 .2 & 108 & pr52_br-usnM & $\begin{array}{l}\text { nomeia e constitui seu } \\
\text { bastante procurador }\end{array}$ & $\begin{array}{l}\text { appoints and } \\
\text { constitutesL ... }\end{array}$ & 3 & $\mathrm{~L}$ & s & $\begin{array}{ll}\text { C1/ D1/ } \\
\text { D2 }\end{array}$ \\
\hline 6.3 .2 & 109 & pr50_br-usL & $\begin{array}{l}\text { nomeio e constituo meu } \\
\text { bastante procurador }\end{array}$ & $\begin{array}{l}\text { nominate and establishL } \\
\text {... }\end{array}$ & 3 & $\mathrm{~L}$ & $\mathrm{n}$ & $\mathrm{A} 1 / \mathrm{C} 2$ \\
\hline 6.3 .2 & 110 & co2_us-brG & $\begin{array}{l}\text { The Undersigned hereby } \\
\text { appoints the Pledgee }\end{array}$ & $\begin{array}{l}\text { Pelo presente } \\
\text { instrumento, o } \\
\text { Signatário nomeia e } \\
\text { constituiEDV o Credor } \\
\text { Pignoratício }\end{array}$ & 5 & EDV & $\mathrm{N}$ & B1 \\
\hline 6.3 .2 & 111 & pr1_usn-brM & $\begin{array}{l}\text { HEREBY MAKES } \\
\text { CONSTITUTES AND } \\
\text { APPOINTS: }\end{array}$ & $\begin{array}{l}\text { NOMEIA E } \\
\text { CONSTITUIEDV }\end{array}$ & 5 & EDV & $\mathrm{s}$ & $\mathrm{D} 2$ \\
\hline 6.3 .2 & 112 & pr2_us-brM & $\begin{array}{l}\text { hereby appoint } \\
\text { Person2...as my Attorney- } \\
\text { in-Fact ("Agent"). }\end{array}$ & $\begin{array}{l}\text { PELO PRESENTE } \\
\text { INSTRUMENTO, } \\
\text { NOMEIOL como } \\
\text { minha bastante } \\
\text { procuradora ... }\end{array}$ & 3 & $\mathrm{~L}$ & $\mathrm{~s}$ & $\mathrm{C} 1$ \\
\hline 6.3 .2 & 113 & dc4_uk-brE & $\begin{array}{l}\text { of the member appointing } \\
\text { the proxy. }\end{array}$ & $\begin{array}{l}\text { do sócio que nomeiaL } \\
\text { o procurador. }\end{array}$ & 3 & $\mathrm{~L}$ & $\mathrm{~s}$ & $\mathrm{C} 1$ \\
\hline
\end{tabular}




\begin{tabular}{|c|c|c|c|c|c|c|c|c|}
\hline 6.3 .2 & 114 & dc4_uk-brE & $\begin{array}{l}\text { HEREBY APPOINT X ... } \\
\text { to be my/our proxy to } \\
\text { vote for me/us at the } \\
\text { meeting of members... }\end{array}$ & $\begin{array}{l}\text { POR MEIO DESTE } \\
\text { INSTRUMENTO } \\
\text { NOMEIOL meu/nosso } \\
\text { bastante procurador }\end{array}$ & 3 & $\mathrm{~L}$ & $\mathrm{~s}$ & $\mathrm{C} 1$ \\
\hline 6.3 .2 & 115 & pr4_ukn-brM & $\begin{array}{l}\text { hereby appoints and } \\
\text { constitutes as its true and } \\
\text { lawful attorneys-in-fact }\end{array}$ & $\begin{array}{l}\text { NOMEIA E } \\
\text { CONSTITUIL como } \\
\text { seus verdadeiros e } \\
\text { legítimos bastantes } \\
\text { procuradores }\end{array}$ & 5 & $\mathrm{~L}$ & $\mathrm{~s}$ & D2 \\
\hline 6.3 .2 & 116 & pr5_usn-brE & $\begin{array}{l}\text { HEREBY appoints and } \\
\text { constitutes Mr. } \\
\text { Person } 2 . . . \text { as its true and } \\
\text { lawful Attorney }\end{array}$ & $\begin{array}{l}\text { nomeia e constituiL seu } \\
\text { bastante procurador ... }\end{array}$ & 5 & $\mathrm{~L}$ & $\mathrm{~s}$ & $\mathrm{D} 2$ \\
\hline 6.3 .2 & 117 & pr7_ukn-brnL & $\begin{array}{l}\text { names and empowers as } \\
\text { its proxy, Person } 1\end{array}$ & $\begin{array}{l}\text { nomeia e constituiEDV } \\
\text { Pessoa1 }\end{array}$ & 5 & EDV & n & D3 \\
\hline 6.3 .2 & 118 & pr9_usn-brB & $\begin{array}{l}\text { credits, grants and } \\
\text { appointments as proxies } \\
\text { the following individuals: }\end{array}$ & $\begin{array}{l}\text { indica, nomeia e } \\
\text { constitui M } \\
\text { procuradores as } \\
\text { seguintes pessoas }\end{array}$ & 5 & $\mathrm{M}$ & $\mathrm{s}$ & D2 \\
\hline 6.3 .3 & 119 & co3_us-brG & jointly and severally & $\begin{array}{l}\text { em conjunto e } \\
\text { separadamenteL }\end{array}$ & 3 & $\mathrm{~L}$ & $\mathrm{~N}$ & B1 \\
\hline 6.3 .3 & 120 & co6_us-brA & jointly and severally liable & $\begin{array}{l}\text { juntamente, e } \\
\text { individualmenteL, } \\
\text { responsável }\end{array}$ & 3 & $\mathrm{~L}$ & n & B1 \\
\hline 6.3 .3 & 121 & co2_us-brG & jointly and severally liable & $\begin{array}{l}\text { individual e } \\
\text { solidariamenteL } \\
\text { responsáveis }\end{array}$ & 3 & $\mathrm{~L}$ & $\mathrm{~N}$ & B1 \\
\hline 6.3 .3 & 122 & pr9_usn-brB & jointly and singularly & $\begin{array}{l}\text { em conjunto ou } \\
\text { separadamenteL }\end{array}$ & 3 & $\mathrm{~L}$ & $\mathrm{~s}$ & D2 \\
\hline 6.3 .3 & 123 & pr9_usn-brB & $\begin{array}{l}\text { individually and } \\
\text { collectively }\end{array}$ & $\begin{array}{l}\text { individual e } \\
\text { coletivamenteL }\end{array}$ & 3 & $\mathrm{~L}$ & $\mathrm{~s}$ & D2 \\
\hline 6.3 .3 & 124 & dc4_uk-brE & singly or jointly & $\begin{array}{l}\text { isolada ou } \\
\text { conjuntamenteL }\end{array}$ & 3 & $\mathrm{~L}$ & $\mathrm{~s}$ & $\mathrm{C} 1$ \\
\hline 6.3 .3 & 125 & dc52_br-usD & solidariamente & joint and severallyEO & 5 & EO & n & D3 \\
\hline 6.3 .3 & 125 & dc54_br-usnE & solidariamente & joint and severallyEO & 5 & EO & $\mathrm{s}$ & A1 \\
\hline
\end{tabular}




\begin{tabular}{|c|c|c|c|c|c|c|c|c|}
\hline 6.3 .3 & 126 & pr51_br-usL & $\begin{array}{l}\text { em conjunto ou } \\
\text { separadamente }\end{array}$ & jointly and severallyL & 5 & $M$ & n & $\mathrm{A} 1 / \mathrm{C} 2$ \\
\hline 6.3 .3 & 127 & co53_br-usnF & $\begin{array}{l}\text { como co-responsáveis, } \\
\text { solidariamente, }\end{array}$ & $\begin{array}{l}\text { as jointEO co- } \\
\text { guarantors }\end{array}$ & 5 & EO & $\mathrm{s}$ & D2 \\
\hline 6.3 .3 & 128 & dc53_br-usnE & $\begin{array}{l}\text { mas todos respondem } \\
\text { solidariamente }\end{array}$ & $\begin{array}{l}\text { although they assume } \\
\text { jointEO liability }\end{array}$ & 5 & EO & n & A1 \\
\hline 6.3 .3 & 129 & co50_br-usL & $\begin{array}{l}\text { tornando-se o XXX S.A., } \\
\text { solidário pagador das } \\
\text { exigências }\end{array}$ & $\begin{array}{l}\text { making XXX S.A. the } \\
\text { soleER payer of the } \\
\text { requirements }\end{array}$ & 3 & ER & $\mathrm{N}$ & B1 \\
\hline 6.3 .3 & 130 & co59_us-brL & $\begin{array}{l}\text { separada ou } \\
\text { conjuntamente }\end{array}$ & separately or jointlyL & 3 & $\mathrm{~L}$ & n & B1 \\
\hline 6.3 .4 & 131 & co3_us-brG & $\begin{array}{l}\text { a corporation duly } \\
\text { organized and validly } \\
\text { existing }\end{array}$ & $\begin{array}{l}\text { sociedade devidamente } \\
\text { constituída e com } \\
\text { existênciaL válida }\end{array}$ & 3 & $\mathrm{~L}$ & $\mathrm{~N}$ & B1 \\
\hline 6.3 .4 & 132 & pr4_ukn-brM & $\begin{array}{l}\text { company duly organized } \\
\text { and existing }\end{array}$ & $\begin{array}{l}\text { sociedade devidamente } \\
\text { constituída e existenteL }\end{array}$ & 3 & $\mathrm{~L}$ & $\mathrm{~s}$ & D2 \\
\hline 6.3 .4 & 133 & pr3_us-brB & $\begin{array}{l}\text { a corporation organized } \\
\text { and existing }\end{array}$ & $\begin{array}{l}\text { sociedade constituída e } \\
\text { existenteL }\end{array}$ & 3 & $\mathrm{~L}$ & $\mathrm{~s}$ & $\mathrm{C} 1 / \mathrm{D} 2$ \\
\hline 6.3 .4 & 134 & co5_us-brJ & $\begin{array}{l}\text { a company established } \\
\text { and existing }\end{array}$ & $\begin{array}{l}\text { empresa constituída e } \\
\text { existenteL }\end{array}$ & 3 & $\mathrm{~L}$ & $\mathrm{~N}$ & D3 \\
\hline 6.3 .4 & 135 & col1_us-brN & $\begin{array}{l}\text { a corporation organized } \\
\text { under the laws }\end{array}$ & $\begin{array}{l}\text { uma sociedade } \\
\text { constituídaL segundo a } \\
\text { legislação }\end{array}$ & 3 & $\mathrm{~L}$ & $\mathrm{~N}$ & B1 \\
\hline 6.3 .4 & 136 & pr8_ukn-brH & $\begin{array}{l}\text { company duly organized } \\
\text { and existing }\end{array}$ & $\begin{array}{l}\text { sociedade devidamente } \\
\text { constituídaL e vigenteM }\end{array}$ & 3 & $\mathrm{~L}$ & n & D3 \\
\hline 6.3 .4 & 137 & co7_usn-brF & $\begin{array}{l}\text { any domestic or foreign } \\
\text { company established }\end{array}$ & $\begin{array}{l}\text { qualquer empresa } \\
\text { nacional ou estrangeira } \\
\text { existenteL }\end{array}$ & 3 & $\mathrm{~L}$ & n & A2 \\
\hline 6.3 .4 & 138 & dc1_us-brE & $\begin{array}{l}\text { The purpose or purposes } \\
\text { for which the Corporation } \\
\text { is organized }\end{array}$ & $\begin{array}{l}\text { O objetivo ou objetivos } \\
\text { para os quais a } \\
\text { Sociedade é } \\
\text { organizadaER }\end{array}$ & 2 & ER & $\mathrm{s}$ & $\mathrm{C} 1$ \\
\hline 6.3 .4 & 139.1 & co2_us-brG & the Undersigned is & o signatário... & 5 & $\mathrm{~L}$ & $\mathrm{~N}$ & B1 \\
\hline
\end{tabular}




\begin{tabular}{|c|c|c|c|c|c|c|c|c|}
\hline & & & incorporated & constituídoL & & & & \\
\hline 6.3 .4 & 139.2 & co2_us-brG & or otherwise organized & $\begin{array}{l}\text { ou por qualquer outra } \\
\text { forma organizadoER }\end{array}$ & 2 & ER & $\mathrm{N}$ & B1 \\
\hline 6.3 .4 & 140 & dc54_br-usnE & $\begin{array}{l}\text { sociedade por quotas de } \\
\text { responsabilidade limitada, } \\
\text { existente e constituída }\end{array}$ & $\begin{array}{l}\text { a limited liability } \\
\text { company, existing and } \\
\text { organizedL }\end{array}$ & 3 & $\mathrm{~L}$ & $\mathrm{~s}$ & A1 \\
\hline 6.3 .4 & 141 & dc53_br-usnE & constituída & organizedL & 5 & $\mathrm{~L}$ & $n$ & A1 \\
\hline 6.3 .4 & 142 & dc51_br-usL & $\begin{array}{l}\text { sociedade devidamente } \\
\text { constituída }\end{array}$ & $\begin{array}{l}\text { a corporation duly } \\
\text { incorporatedL }\end{array}$ & 5 & $\mathrm{~L}$ & n & A1 \\
\hline 6.3 .5 & 143 & co11_us-brN & $\begin{array}{l}\text { REPRESENTATIONS } \\
\text { AND WARRANTIES }\end{array}$ & $\begin{array}{l}\text { DECLARAÇÕES E } \\
\text { GARANTIASL }\end{array}$ & 3 & $\mathrm{~L}$ & $\mathrm{~N}$ & B1 \\
\hline 6.3 .5 & 144 & co3_us-brG & representation or warranty & declaração ou garantiaL & 3 & $\mathrm{~L}$ & $\mathrm{~N}$ & B1 \\
\hline 6.3 .5 & 145 & co7_usn-brF & $\begin{array}{l}\text { representations and } \\
\text { warranties }\end{array}$ & $\begin{array}{l}\text { representaçõesER e } \\
\text { garantiasL }\end{array}$ & 2 & ER-L & $n$ & A2 \\
\hline 6.3 .5 & 146 & co7_usn-brF & representation or warranty & $\begin{array}{l}\text { representaçãoL nem } \\
\text { apresenta qualquer } \\
\text { garantiaL, }\end{array}$ & 3 & $\mathrm{~L}$ & n & A2 \\
\hline 6.3 .5 & 147 & co6_us-brA & $\begin{array}{l}\text { contracts, warranties or } \\
\text { representations }\end{array}$ & $\begin{array}{l}\text { contrato, garantiasL ou } \\
\text { representaçõesER }\end{array}$ & 2 & ER-L & n & B1 \\
\hline 6.3 .5 & 148 & co2_us-brG & $\begin{array}{l}\text { representation, warranty } \\
\text { or covenant }\end{array}$ & $\begin{array}{l}\text { declaração, garantiaL } \\
\text { ou acordo }\end{array}$ & 3 & $\mathrm{~L}$ & $\mathrm{~N}$ & B1 \\
\hline 6.3 .5 & 149 & co2_us-brG & $\begin{array}{l}\text { representation or warranty } \\
\text { made or entered into }\end{array}$ & $\begin{array}{l}\text { declaraçãoL efetuada ou } \\
\text { garantiaL assumida }\end{array}$ & 3 & $\mathrm{~L}$ & $\mathrm{~N}$ & B1 \\
\hline 6.3 .5 & 150 & col1_us-brN & represents and warrants & declara e garanteL & 3 & $\mathrm{~L}$ & $\mathrm{~N}$ & B1 \\
\hline 6.3 .5 & 150 & co2_us-brG & represents and warrants & declara e garanteL & 3 & $\mathrm{~L}$ & $\mathrm{~N}$ & B1 \\
\hline 6.3 .5 & 150 & co3_us-brG & represents and warrants & declara e garanteL & 3 & $\mathrm{~L}$ & $\mathrm{~N}$ & B1 \\
\hline 6.3 .5 & 151 & co6_us-brA & represents and warrants & $\begin{array}{l}\text { representaER e } \\
\text { garanteL }\end{array}$ & 2 & ER-L & $n$ & B1 \\
\hline 6.3 .5 & 152 & co5_us-brJ & declare and warrant, & declaram e garantemL & 3 & $\mathrm{~L}$ & $\mathrm{~N}$ & D3 \\
\hline
\end{tabular}

